\title{
Raymond Williams and European Marxism: Lukacs, Sartre, Gramsci
}

\author{
Gerke, Daniel, R.
}

How to cite:

Gerke, Daniel, R. (2018) Raymond Williams and European Marxism: Lukacs, Sartre, Gramsci. Doctoral thesis, Swansea University.

http://cronfa.swan.ac.uk/Record/cronfa46244

Use policy:

This item is brought to you by Swansea University. Any person downloading material is agreeing to abide by the terms of the repository licence: copies of full text items may be used or reproduced in any format or medium, without prior permission for personal research or study, educational or non-commercial purposes only. The copyright for any work remains with the original author unless otherwise specified. The full-text must not be sold in any format or medium without the formal permission of the copyright holder. Permission for multiple reproductions should be obtained from the original author.

Authors are personally responsible for adhering to copyright and publisher restrictions when uploading content to the repository.

Please link to the metadata record in the Swansea University repository, Cronfa (link given in the citation reference above.)

http://www.swansea.ac.uk/library/researchsupport/ris-support/ 
$\underline{\text { Raymond Williams and European Marxism: Lukacs, Sartre, Gramsci }}$

\author{
Daniel Robert Gerke
}

Submitted to Swansea University in fulfilment of the requirements for the Degree of Doctor of Philosophy

Swansea University

2018 


\section{Summary}

Raymond Williams and European Marxism: Lukacs, Sartre, Gramsci

The Western Marxist tradition from Lukacs to Colletti is usually considered a continental European one, with no major British representative. This thesis presents the Welsh cultural critic and novelist Raymond Williams (1921-1988) as a critical Anglophone participant in that tradition. The development of Williams's cultural materialism, far from being the product of a rigid 'British' empiricism, was centrally influenced by the ideas of Western Marxist thinkers. At the core of this influence, and of the 'European' rationalist element in Williams's work, is the concept of 'totality', an abiding concern with which Williams shares with the Western Marxists. The three European Marxists to whom Williams's intellectual development is most indebted are those whom he described, in 1972, as 'Marxism's alternative tradition': Georg Lukacs (1885-1971), Jean-Paul Sartre (1905-1980) and Antonio Gramsci (1891-1937). The work of these thinkers, as it slowly appears in English, confirms Williams's insistence on 'total' analysis and permits him to generate a Marxism capable of reconciling subjective experience with the complex materiality of social relations. I read the theoretical apparatus which results from these transnational interactions as a literary and a philosophical realism committed both to the aesthetic representation of the social totality and to the interaction of experience with objective reality. The form of political praxis engendered by these European influences is a 'revolutionary culturalism' in which the working-class attains hegemony by realising its experience and interests in a concrete culture. 


\section{Contents}

Acknowlegements $\quad$ i

Abbreviations $\quad$ ii

Introduction

Raymond Williams: 'our' Western Marxist?

The meaning of Williams's Europeanism: critical perspectives

Raymond Williams and European theory: an outline 29

Chapter 1 - Williams and Lukacs: Realism, Totality, Class

An outline of Williams's engagement with Lukacs 41

Williams and Lukacs in the sixties $\quad 50$

Finally, History and Class Consciousness $\quad 56$

$\begin{array}{ll}\text { Cultural materialism and the break with Lukacs } & 68\end{array}$

$\begin{array}{ll}\text { Travelling theory } & 78\end{array}$

A man without frustration $\quad 91$

Chapter 2 - Williams and Sartre: Tragedy, Freedom, Nation

An outline of Williams's engagement with Sartre 101

The modern tragedy is the Sartrean tragedy $\quad 110$

$\begin{array}{ll}\text { Beyond tragedy: Brecht } & 128\end{array}$

Williams and Sartre on the individual and society 143

Williams and Sartre on freedom and commitment in literature $\quad 154$

From the common culture to the Burgos Trials 165

Dialectical materialism and the politics of place $\quad 180$

Chapter 3 - Williams and Gramsci: Culture, Submission, Emergence

An outline of Williams's engagement with Gramsci 193

Hegemonic culture as lived domination $\quad 196$

$\begin{array}{ll}\text { The long war of position } & 206\end{array}$

$\begin{array}{ll}\text { Conclusion } & 224\end{array}$

Bibliography 


\section{Acknowledgements}

I would like to thank my supervisors, Professor Daniel G. Williams and Professor Julian Preece, both for securing the funding that made this possible and for their many advices and encouragements. I am grateful to a number of scholars (and friends) in the English Literature and Creative Writing and Modern Languages departments who contributed in vital ways to the completion of this project.

The present work would not have been possible without the diligence of the whole team at the Richard Burton Archives, on whose time I regularly encroached.

I am indebted to my friends and family who supported me throughout, for their generosity and love. My parents, step- and otherwise, for always being there. Alice, for enduring my being buried in books.

I thank Raymond Williams for his work, the prolific creativity of too short a life.

This thesis is dedicated to the memory of Doris Frost. 


\section{Abbreviations}

Books by Raymond Williams:

CS - Culture and Society (1958)

DFIB - Drama from Ibsen to Brecht (1968)

DFIE - Drama from Ibsen to Eliot (1953)

ENDL - The English Novel from Dickens to Lawrence (1970)

$M L$ - Marxism and Literature (1977)

MT-Modern Tragedy (1966)

$P L-$ Politics and Letters (1979)

TLR - The Long Revolution (1961)

Articles by Raymond Williams:

'LGM' - 'Lucien Goldmann and Marxism’s Alternative Tradition' (1972)

Books by E. P. Thompson:

TMEWC - The Making of the English Working Class (1963)

TPOT - The Poverty of Theory and other Essays (1978)

Books by Georg Lukacs:

ER - Essays on Realism (German: 1971 [essays written in the thirties], English: 1980)

HCC - History and Class Consciousness (German: 1923, English: 1971)

MCR - The Meaning of Contemporary Realism (German: 1958, English: 1963)

SER - Studies in European Realism (English: 1950)

THN - The Historical Novel (German: 1937, English: 1962)

Plays by Jean-Paul Sartre:

TDGL - The Devil and the Good Lord (French: 1951, English: 1960)

Plays by Bertolt Brecht:

TGWS - The Good Woman of Szechwan (German: 1941, English: 1962)

Other:

NLR - New Left Review 


\section{$\underline{\text { Introduction }}$}

\section{Raymond Williams: 'Our' Western Marxist?}

Raymond Williams's crucial statement of affinity with the vital, internationalist tradition of Western Marxism came at a relatively late stage in his career, in the introduction to Marxism and Literature (1977):

It was in this situation ${ }^{1}$ that I felt the excitement of contact with more new Marxist work: the later work of Lukacs, the later work of Sartre, the developing work of Goldmann and of Althusser, the variable and developing syntheses of Marxism and some forms of structuralism. At the same time, within this significant new activity, there was further access to older work, notably that of the Frankfurt School (in its most significant period in the twenties and thirties) and especially the work of Walter Benjamin; the extraordinarily original work of Antonio Gramsci; and, as a decisive element of a new sense of the tradition, newly translated work of Marx and especially the Grundrisse. As all this came in, during the sixties and the early seventies, I often reflected, and in Cambridge had direct cause to reflect, on the contrast between the situation of the socialist student of literature in 1940 and in $1970 \ldots$ an argument that had drifted into deadlock, or into local and partial positions, in the late thirties and forties, was being vigorously and significantly reopened.

... my own long and often internal and solitary debate with what I had known as Marxism now took its place in a serious and extending international enquiry. I had opportunities to extend my discussions in Italy, in Scandinavia, in France, in North America, and in Germany, and with visitors from Hungary, Yugoslavia, and the Soviet Union. This book is the result of that period of discussion, in an international context in which I have had the sense, for the first time in my life, of belonging to a sphere and dimension of work in which I could feel at home. (2009 [1977], pp. 4-5)

This unambiguous statement of intellectual and personal connection must have been read with incredulity by Williams's critics of the seventies. For Williams was viewed even by sympathetic commentators as an irreducibly British or, more egregiously, given his Welsh heritage, English thinker. Both his politics and his critical methodology were read both as uninfluenced by and as actively incompatible with the tradition of dissident European Marxism cited by Williams above. Perhaps the starkest example of this view was Tom Nairn's (1972) characterisation of Williams as a 'cultural nationalist': '[Williams is] the outstanding contemporary (perhaps the greatest) representative of national culture: he represents the most valiant and unremitting effort to formulate a valid left-wing Weltanschauung out of the materials of national culture, through the organic inheritance of

\footnotetext{
${ }^{1}$ Williams is referring to a period from the late sixties to mid-seventies, in which a very large number of texts from European writers were made available in English for the first time (see p. 31-32).
} 
one rich nation-state's heritage' (p. 108). Now, while Williams's broadly 'culturalist' emphasis did necessitate the production of a cultural consensus (hegemony) fit for socialism, English culture was definitely not its source. While the Welsh emphasis in Williams's work did not properly emerge until the seventies (Nairn, writing in 1972, may be forgiven for missing it), Williams was from much earlier a staunch critic of 'official' English culture. His early writings on the idea of a socialist "common culture" ${ }^{, 2}$ were not inspired by the national images of English or British life, but by an idealised image of working-class culture, itself drawn from the Welsh working-class culture of his upbringing.

It is no surprise that the same writers who missed Williams's increasing attachment to Wales were also those least willing to accept his Europeanism. For by the late seventies Williams had come to see these two elements in his mature formation as inextricable, and as organised around a complexly articulated rejection of England and English culture. In the interview collection Politics and Letters (1979), Williams announced that he was a 'Welsh European', in another crucial expression of affinity with Europe:

[From the late sixties] I began having many more contacts with Welsh writers and intellectuals, all highly political in the best tradition of the culture, and I found this curious effect. Suddenly England, bourgeois England, wasn't my point of reference anymore. I was a Welsh European, and both levels felt different. There's still a lot to work through from that, but I can hardly describe the difference of talking and relating now in Wales, with writers and political comrades who are all hard up against it - what's seen from outside is a remarkable vitality, and so it objectively is, but there it's a hard, fierce, internally contending yet bitterly communal feeling, which is also where I happen to be and now in the truest sense to be from. Through the intricacies of the politics, and they are very intricate indeed, I want the Welsh people - still a radical and cultured people - to defeat, override or bypass bourgeois England; the alternative flows from the intricacies. That connects, for me, with the sense in my work that I am now necessarily European; that the people to the left and on the left of the French and Italian communist parties, the German and Scandinavian comrades, the communist dissidents from the East like Bahro, are my kind of people; the people I come from and belong to, and my more conscious Welshness is, as I feel it, my way of learning those connections ... when highly cosmopolitan Welsh intellectuals offer recognition of the whole range of my work, which literally none of my official English colleagues has seen a chance of making sense of, then I am in a culture where I can breathe. Or at least take breaths to go back and contend with capitalist Europe, capitalist England and - blast it, but it was there and had to be shown in Manodcapitalist Wales. (2015 [1979], p. 296)

It is the idea of bypassing England, then, which connects the Welsh and European elements in Williams's work, not any essential compatibility between Welsh and European modes of

\footnotetext{
${ }^{2}$ See, Chapter Two, pp. 165-192, for a summary and discussion of these texts.
} 
thought and culture which, as Williams recognised, were themselves internally heterogeneous. English culture too, of course, was multiplicitous and, in Adorno’s phrase, 'politically polyvalent' (2007, p. 178). E. P. Thompson, who collaborated with Williams on the May Day Manifesto (1967), demonstrated precisely this political polyvalence in his defences (1965 \& 1978) of an English intellectual and cultural inheritance against Anderson and Nairn's continental theoreticism in the sixties. ${ }^{3}$ We shall find in Williams's writings on the European thinkers mentioned above many scathing remarks about dominant, especially intellectual, 'English' tropes and values. But his opposition to England is not based on an essentialising view of England any more than his Welshness or his Europeanism are based on reactive or displaced cultural nationalisms. What Williams wants to bypass in England is not its Weltanschauung or Nationalgeist but its status as dominant, the writing of dominant English culture over both English life and the cultures of the subordinate British nations. For Williams, the culture of the English ruling class represents what I will call, following Sartre in 'The Burgos Trials' (1971), abstract universality, a falsely universal culture which seeks to block, alter or appropriate those cultural forms which either pre-exist or emerge in opposition to it. English culture claims the right to adjudicate the different values, meanings and practices which exist in Britain, the variegated culture of real people living contradictory but concrete lives. Welsh and European cultural elements, conversely, come to represent variants of what Williams would later call the 'emergent': rising meanings and values which signal opposition to the dominant level of a given, in Williams's own life English, hegemony.

If the above thesis is correct, it is perhaps no coincidence that the first critic to connect Williams to a Western Marxist was a fellow Welshman, Gwyn A. Williams (1960), writing on Gramsci's cultural humanism in an early English-language essay on egemonia (hegemony):

It is this quality which makes Gramsci such an unexpectedly congenial writer to readers familiar with the current British literature on social and cultural relationships, which owes not a little to Morris. For much of this literature is being produced by Socialist thinkers who, for a variety of reasons, are becoming increasingly preoccupied with problems of a similar character. Indeed to come from Gramsci to, say, Raymond Williams's classic study of the interplay of social and cultural values in modern British history, Culture and Society, 1980-1950, is to experience a peculiar sense of contact and continuity. (1960, p. 596)

\footnotetext{
${ }^{3}$ See pages 13-19 and 21-23 for discussion of this debate.
} 
Gwyn A. Williams's comparison marked the first connection made between Williams and a European Marxist; it was by no means the last. A young Terry Eagleton (1976), who otherwise regarded Williams as inextricably bound by English cultural assumptions, would describe Williams's work as 'the most suggestive and intricate body of socialist criticism in English history - criticism for which no English comparison is even remotely relevant, but which must be referred for comparative assessment to the aesthetic production of a Lukacs, Benjamin or Goldmann' (1976, p. 9). He would later use the more explicit phrase 'the British equivalent of Lukacs' (2009, p. 96). Anthony Barnett (1976) drew a rough biographical equivalence between Sartre and Williams, with which The Times appears to have agreed in an obituary for 'our nearest British equivalent to Sartre. ${ }^{4}$ Tony Pinkney (2007b), anxious to rescue a modernist Williams from Eagleton's 'British Lukacs' thesis, ventured the British Bloch. Later, Bridget Fowler (2000), shrewdly connecting Williams's 'structure of feeling' to Bourdieu's 'habitus' would position Williams as the French sociologist's closest British equivalent. Andrew Milner (2002), in an innovative reading of Williams as a 'postculturalist' thinker, reads Williams as being to British culturalism what Habermas is to German critical theory and Foucault to French structuralism: a thinker both engaged in and moving beyond an antecedent 'national' problematic.

The above interventions are only the most explicit equivalences made between Williams and thinkers from the Western Marxist and adjacent European traditions; as we shall see, there is a significant critical literature in which a variety of other comparisons and claims of influence are made. For now, it is worth noting the frequency with which claims roughly following the pattern "Williams = "the British X"' are made. Why should this be so? After all, nobody refers to Goldmann as 'the French Lukacs'. As I aim to show in this introduction, the answer is more complicated than it may appear. At the most basic level, it is because Britain is not generally thought to have produced a Marxist thinker, during the pre- and post-war years, of the calibre or influence of the major figures of Western Marxism. Where this is not read as a surfeit of national quality, it is read, as in Williams's case, as a surfeit of national Marxism; this thesis finds its most systematic expression in the Nairn-Anderson theses of the midsixties, which I address in the next section. Goldmann, then, is not 'the French Lukacs' because he is, in a self-sufficient way, 'the French Goldmann'. I want to ask whether Williams might not be considered simply 'the British (or Welsh, or even English) Williams',

\footnotetext{
${ }^{4}$ This quote appears on the cover of the What I Came to Say (1990) and is attributed to a Times obituary. I have not been able to locate the original.
} 
so that, in moving through that tautology, it would no longer be necessary to append to another thinker's name the word 'British' (or 'Welsh' or 'English') to evoke Williams's connection to, or inclusion within, the Western Marxist canon.

By 1979, something like this had almost taken place. Anderson, Barnett and Francis Mulhern carried out wide-ranging interviews with Williams for Politics and Letters. The following passage is from the foreword, authored by the three New Left Review editors:

$N L R$, as it took shape in the mid-sixties, had repeatedly expressed the view that no autonomous or mature Marxism could emerge in Britain without taking the full measure of Williams's contribution to socialist thought ... Yet the Review proved no more able than other journals in these years to take adequate stock of Williams's growing achievement. In relation to modern traditions of socialist theory, its major effort lay elsewhere. In this period $N L R$ pursued a systematic enterprise of introduction and evaluation of the main schools within continental Marxism whether those of Lukacs or Sartre, Gramsci or Althusser, Adorno or Della Volpe ... The present volume is a natural and necessary extension of that work, turning to consider the pre-eminent intellectual representative of socialism in contemporary Britain, at a time when Williams's own writing has consciously rejoined a wider international Marxist debate. (2015 [1979], pp. 8-9)

The passage is replete with contradictions. If Politics and Letters, a wide-ranging discussion of Williams's life and work, is 'a natural and necessary extension' of the work of elaborating Western Marxism to a British audience, then Williams is, by implication, a figure in that canon: Britain's Western Marxist. At the same time, Williams is described not as the 'preeminent intellectual representative' of Marxism in Britain, but of the broader 'socialism'; the $N L R$ editors evade having to spell out what was implied a moment before. They concede that Williams's writings are now part of 'a wider internationalist Marxist debate' and yet this contribution is described as being to socialist, not to Marxist thought, and a British Marxism will emerge not in Williams's own work, but by others taking its 'full measure'. The tension between Freud's 'reality' and 'pleasure' principles is enacted here. Williams's interlocutors express a deep desire for a British, that is a 'native' Marxism (and for Williams's work to be it), all the while grappling with the intellectual intuition that the phrase 'British Marxism' is oxymoronic, the word 'Marxist' itself a cipher for 'European'.

As a case study, it will be worth interrogating Perry Anderson's omission of Williams from his canonization (1976) of the Western Marxist tradition. By 1979, after all, the editors of New Left Review collectively regarded Politics and Letters as the next phase of their longstanding project of introducing and critiquing that very tradition. The most obvious 
justification of Williams's absence is that Western Marxism refers exclusively to a continental European tradition. But there is nothing in Anderson's account, or indeed in his broader writings, to suggest that he would have opposed including a British thinker if he thought one appropriate. In fact, quite the opposite; one of the core concerns of Anderson's work in the sixties and seventies was his sense of the lamentable absence of a Marxist thinker of stature in Britain, countable among the giants of continental Europe.

So, what disqualified Williams? Anderson suggests a number of biographical and thematic similarities between the most prominent thinkers of the Western Marxist tradition, to which we can add at least two others (see below). I have italicized those features which I think Williams can reasonably be said to share with the thinkers of Anderson's canon. ${ }^{5}$ Plain text designates a clear difference and bold text indicates a partial or contradictory overlap:

Primary features of Western Marxist thinkers/tradition (Anderson, 1976)

- Born between 1885 (Lukacs) and 1924 (Colletti)

- Middle-class/bourgeois upbringings (exc. Gramsci)

- From West of Vienna/Prague (exc. Lukacs and Goldmann)

- Formed politically by either WW1 + Russian Revolution or WW2

- Professional academics

- Generally, from countries with a Communist party leading a militant working class, and a numerous and radical intelligentsia

- Break with the organic unity of theory and practice (de-linked from revolutionary activity)

- Work produced in situations of defeat/despair

- Pessimism

- Shift in focus from politics and economics to philosophy and 'method'

- Presence and influence of European idealism

- Rejection of the late works of Engels

- Focus on superstructures

Additional features

\footnotetext{
5 Anderson's canon, in order of birth: Lukacs (1885-1971), Korsch (1886-1961), Gramsci (1891-1937), Benjamin (1892-1940), Horkheimer (1895-1973), Della Volpe (1897-1968), Marcuse (1898-1979), Lefebvre (1901-1991), Adorno (1903-1969), Sartre (1905-1980), Goldmann (1913-1970), Althusser (1918-1990), Colletti (1924-2001).
} 


\section{- Focus on ideology as an explanation for proletarian 'consent'}

- Central use of the notion of totality ${ }^{6}$

Let us begin with the similarities. Williams would be one of youngest thinkers, but older than Colletti and only three years younger than Althusser. Like the younger sub-set (from Lefebre onwards), Williams came of age during the rise of fascism and WW2. He joined the student branch of the Communist Party on the eve of the war and saw combat. Anderson (1976) notes that only Lukacs, Korsch and Gramsci, the three oldest figures, were leaders within political parties; from then on, while "Marxism did not "stop", as Sartre was later to claim ... it advanced via an unending detour from any revolutionary practice' (1987, p. 42). Williams joins the post-Gramsci Western Marxists in owing his political maturity largely to the period after that of active revolutionary agitation in Russia and Europe. Like the thinkers of the Frankfurt School and the younger Italian and French Marxists, Williams contributed to Marxist thought primarily from within academia, though he was never politically inactive, being in turn a member of the Labour Party (1961-66) and Plaid Cymru ${ }^{7}$. Williams wrote in a period marked by the long shadow of Stalinism, ${ }^{8}$ extended periods of Conservative rule, the disappointments of the Wilson Labour governments ${ }^{9}$ and, later, the rise of neoliberalism. ${ }^{10}$ While Williams never succumbed to any general pessimism, this accumulation of defeats meant that his work was indeed produced, as Anderson (1976) writes of the Western Marxist tradition as a whole, 'in situations of political isolation and despair' (p. 42).

These are the most obvious biographical and conjunctural similarities between Williams and the Western Marxists, but there is also significant overlap of intellectual themes and objects. Anderson (1976) argues that the "most striking single trait of Western Marxism as a common tradition is ... perhaps the constant presence and influence on it of successive types of European idealism' $\left(1987\right.$, p. 56). ${ }^{11}$ Williams's own relation to idealist thought was complex. He viewed his own mature theory as materialist and Marxist and was dismissive of orthodox

\footnotetext{
${ }^{6}$ See Jay (2004) for a book-length discussion of the concept of totality in Western Marxism.

${ }^{7}$ Exact dates unknown. Williams (2003c) 'Decentralism and the Politics of Place' states that he was a member for 'a year or two' (p. 206), probably in 1971-73.

${ }^{8}$ The 1956 Hungarian Revolution (in which Lukacs participated) and subsequent Soviet invasion were formative moments in the New Left's rejection of Soviet-led Communism.

${ }^{9}$ Williams's most programmatic political intervention, the May Day Manifesto (1968), to which E. P. Thompson and Stuart Hall contributed, was a response to the failures of the first Wilson government.

10 'Plan X' (p. 244) in the language of Williams's Towards 2000 (1985d).

${ }^{11}$ See Anderson (1987), (pp. 56-57) for details. For our purposes, the influence of European idealism includes in almost all cases Hegel; for Lukacs also Weber and Simmel's sociology, Dilthey and Lask's neo-Kantian philosophy; for Gramsci, the idealist thought of Croce; for Sartre, the phenomenology and existentialism of Husserl and Heidegger.
} 
Marxist critiques of the idealist elements in his own work and that of the Western Marxist thinkers that influenced him. Speaking of his discovery of Lukacs and Goldmann's work in 'Literature and Sociology' (1971), he says tersely: 'The fact that I learned simultaneously that it had been denounced as heretical, that it was a return to Left Hegelianism, left-bourgeois idealism, and so on, did not, I am afraid, detain me. If you're not in a church you're not worried about heresies' (2005f, p. 20). Eagleton (1976) would attack Williams in precisely these terms, accusing his early work of reducing the social formation to a "circular", Hegelian totality' (p. 11) within the framework of an 'idealist epistemology' (p. 12) and describing the product of Williams's later rapprochement with Marxism (an original interpretation of Gramsci's hegemony ${ }^{12}$ ) as a 'fraught, dissentient, intellectually unclarified affair' (p. 23). However one evaluates the consistency of Williams's later positions, it is clear that elements of both idealist and materialist intellectual traditions inform Williams's mature cultural materialism. The idealist element originates in the inheritance of the English literary tradition in which Williams was trained, ${ }^{13}$ the materialist element in a more obviously transnational provenance: British philosophical and scientific materialism, stretching back to Hobbes, and Marxism itself.

In Culture (1981), Williams would explicitly accede to his dual formation by describing his 'sociology of culture' as participating in 'a new kind of convergence' (p. 12) between previously antagonistic idealist and materialist traditions in conceiving of culture as a 'whole way of life'. 'Whole way of life' is in fact an older version, taken up afresh in Culture, of what for most of Williams's career would be called 'totality', the irreducible connectedness of all elements of social life. An abiding concern with this idea of the total interrelation of parts within a social order was a hallmark of Western Marxism from Lukacs onward, ${ }^{14}$ as well as other British Marxists influenced by continental thought. ${ }^{15}$ The young Eagleton connected its use in Williams to Hegelian idealism but, as Milner (2002) points out, there are forms of materialism which also refuse to make absolute distinctions between, for example, culture and non-culture: 'A rigorous materialism, such as that proposed by Hobbes and subsequently pursued by modern economic theory, is ... fundamentally unable to conceive of the cultural as meaningfully distinguishable from the economic and the political' (p. 15).

\footnotetext{
${ }^{12}$ See Chapter Three for an extended analysis of Williams's theory of hegemony.

${ }^{13}$ See Milner (2002) for an account of the Anglo-European roots of English literary criticism, i.e. 'English literary criticism was influenced by German idealism by way of English and German Romanticism, especially through Coleridge' (p. 15). Coleridge, of course, was a major figure in Williams's Culture and Society.

${ }^{14}$ See Jay (2004), pp. 81-127 for details.

${ }^{15}$ See, in particular, pp. 14-18 for discussion of the importance of totality for the 'Nairn-Anderson thesis'.
} 
Williams's resolute focus on culture as 'the whole historical social and material process' (2005g, p. 52) and his insistence, in Culture and elsewhere, that one cannot meaningfully distinguish the realm of the 'aesthetic' from the rest of social life, ${ }^{16}$ would seem to align him with this 'rigorous materialism'. But in, to cite only a few examples, his abiding concern with feeling and experience, his account of generative or 'emergent' forms of consciousness and his late adoption of the language of 'signification' (drawn from a critical engagement with Saussurian linguistics), there are enough idealist or neo-idealist elements in Williams's work that Milner (2002) is right to describe cultural materialism as 'the paradigmatic instance, in the English-speaking world at least, of precisely this new kind of convergence' (p. 18).

As we shall see, much of the critical literature on Williams in the seventies and eighties revolves around the question of whether a properly Marxist theory of culture can be generated from the kind of 'irreducibility' or 'non-categorical' approach that Williams favoured. At stake in these debates are different conceptions of the 'functional' nature of the totality i.e. the specific processes by which its interconnected parts are articulated. This is related, in turn, to the question posed by the traditional Marxist binary of 'base and superstructure', namely of the relation of cultural and otherwise 'non-economic' elements to what is usually conceived of as a determining material or productive 'base' given by the mode of production. Like the canonical thinkers of Western Marxism, Williams's work is primarily concerned with that portion of social life traditionally placed within the 'superstructure', in particular the creative arts and 'consciousness'. The key point then, and here we move into the sphere of Williams's differences from the Western Marxist tradition, is that the period of Williams's work in which his engagement with Marxism is strongest (the seventies) is in effect an extended critique of base and superstructure as inherited from orthodox Marxism. The Western Marxist tradition holds a variety of ambiguous and often contradictory positions on this central tenet of historical materialism. Insofar as Williams's critique draws heavily on the steps taken by Western Marxists beyond 'vulgar' or 'mechanical' materialist versions of base and superstructure, he is working within that tradition and its contradictions. Insofar as Williams is really dismantling the theory and constructing something else in its place, he may be regarded as outside it. In this sense, Williams's later work moves within a conceptual space which is both within and beyond the problematic of Western Marxism.

\footnotetext{
${ }^{16}$ See pp. 72-77 for discussion of Williams's opposition to the 'specificity of the aesthetic' in Marxism and Literature.
} 
A further ambiguity in Williams's relation to Western Marxism is the fact that he devotes relatively little space to traditional philosophical questions. For Anderson (1976), a striking feature of Western Marxism was the 'overwhelming predominance of professional philosophers within it' (1987, p. 49). Williams's training as a literary critic marks him out, but what is then interesting is that this did not prevent him from developing an abiding concern with what Anderson calls 'method'. Indeed, The Long Revolution (1961), Marxism and Literature (1977) and Culture (1981) may be regarded as successive book-length attempts to produce a general framework for the study of the social totality; they are comparable, in this sense, to texts like Lukacs's 'What is Orthodox Marxism?' (1919) and Sartre's The Problem of Method (1957). What distinguishes Williams's work from these texts, and indeed from what Anderson call the 'obsessive methodologism' (1987, p. 53) of Western Marxism, is a) that most of Williams's critical texts are highly specific analyses of cultural and other objects, rather than philosophical exegeses, and b) that even the more methodological texts are not centrally concerned with the question of knowledge (epistemology), even where Williams's cultural analyses do court ontological debates on the nature of material reality, social causation etc. Williams's work is significant, however, for one long-standing epistemological debate of serious import for the British Left in the sixties and seventies: the question of empiricism vs. rationalism. In Chapter Two of this thesis I argue that while Williams's early work is indeed largely empiricist, rationalist arguments about the limits of experience and the necessity of 'abstract' cognition become increasingly present throughout his 'Europeanist' period (roughly, 1968-79).

Williams's work also bears an ambiguous relation to Western Marxism on the question of the role of ideology in disciplining and adapting the working-class to its subservient position within capitalism; in short, whether ideology is generative of consent (Gramsci) or even, in stronger forms of the argument, of subjectivity itself (as in Althusser's 'interpellation, ${ }^{17}$ ). As we shall see, Williams is entirely opposed to the strong Althusserian view that workers are 'interpellated' into a given subject-position by the ideological matrix of capitalist social relations, nor will he concede that the working class has been 'duped' into giving its consent. The former argument clashes with Williams's humanism, the latter with his empiricism: human beings are not functions or reflections of systems of power and consciousness cannot be dismissed as inadequate merely on the grounds that workers misperceive their economic interests. It is the relatively positive valence which Williams grants ordinary experience

\footnotetext{
${ }^{17}$ See Althusser (2008) for a full account.
} 
which renders him unable to accede to the more pessimistic accounts of culture and consciousness produced within Western Marxism; his affirmative account of the creative and generative nature of consciousness puts Williams firmly at odds with Althusser, but also, as we shall see, with Adorno and Horkheimer's 'negative' critical theory, Marcuse's OneDimensional Man (1964) and Timpanaro's melancholic physicalism, ${ }^{18}$ among others.

A central feature of Williams's work is an absolute rejection of elitism. ${ }^{19}$ In large part, Williams's anti-elitism accounts for his rejection of theories which deride the creative capacities of the working class and its potential to self-generate forms of consciousness conducive to socialism. It has been argued, not least by Williams himself, that this attitude which, paralleled in the work of Hoggart and Thompson, would come to be called the 'culturalist' emphasis, stemmed from Williams's working-class upbringing in the Welsh border village of Pandy; his father was a signalman active in trade union and Labour politics. The bourgeois formations of the Western Marxists are a far cry from Williams's own, and he provides us with numerous anecdotes to indicate the resilience of this formation against the quite different 'structure of feeling' of the class situation into which he entered at Cambridge. ${ }^{20}$ In Politics and Letters, Williams suggested that his trajectory was a commoner one in Wales than in England: 'Historically, Welsh intellectuals have come in very much larger numbers from poor families than have English intellectuals, so the movement is not regarded as abnormal or eccentric. The typical Welsh intellectual is - as we say - only one generation away from shirt sleeves' (1979, p. 29). Indeed, it is Williams's working-class formation (though not, indeed never, his Welshness) which Anderson, in his single mention of Williams in Considerations, emphasises as his unique and vital asset as an intellectual, prefacing the point with an endorsement of Gramsci's well-known typology:

The "organic intellectuals" envisaged by Gramsci, generated within the ranks of the proletariat itself, have not yet occupied the structural role in revolutionary socialism that he believed would be theirs. The extreme forms of esotericism that have characterized Western Marxism were symptomatic of "traditional intellectuals" in Gramsci's sense, in a period when there was little or no contact between socialist

\footnotetext{
${ }^{18}$ See Williams (2005i) for an essay-length discussion of Timpanaro's influential On Materialism (year) and The Freudian Slip (year).

${ }^{19}$ On the question of whether anti-elitism necessitates 'populism', Williams (2005h) provides a nuanced account in 'Notes on Marxism in Britain Since 1945', pp. 239-243.

${ }^{20}$ See Politics and Letters (2015 [1979]) for the best known of these, wherein Williams at Cambridge protests the Leavisite claim that the industrial revolution rendered the word 'neighbour' in Shakespeare incomprehensible to modern ears: 'I got up and said I thought this was only differentially true; there were obviously successive kinds of community, and I knew perfectly well, from Wales, what neighbour meant' (p. $67)$.
} 
theory and proletarian practice. But in the long run, the future of Marxist theory will lie with intellectuals organically produced by the industrial working classes of the imperialist world themselves, as they steadily gain in cultural skill and selfimportance. (1987, p. 105)

[Then, in a footnote on the same page]

Perhaps the most distinguished socialist thinker to have so far come from the ranks of the Western working class itself has been a Briton, Raymond Williams. Yet Williams's work, while it has corresponded closely to the pattern of Western Marxism in its typically aesthetic and cultural focus, has not been that of a Marxist. However, its class history - steadily and confidently present throughout Williams's writings has conferred on this work certain qualities which cannot be found anywhere else in contemporary socialist writing, and which will be part of any future revolutionary culture. (p. 105)

In describing Williams as a 'Briton' rather than as a Welshman, Anderson expresses the central desire of that younger, more militantly Marxist generation of $N L R$ editors ${ }^{21}$ in the sixties and seventies: the construction of a distinctively British Marxism which could hold its own, in intellectual terms, with the vibrant continental European traditions then at their height. As we shall see, this was an enterprise fraught with contradictions, a fascinating case study in which is the significance of Williams for those engaged in it. For at different moments and in different hands, Williams appears as both a) the figure to whom a British or 'English' Marxism will be most indebted and b) a symbol of the very intellectual weaknesses which make the prospect of a 'native' British Marxism impossible, and which necessitate the building of a Marxist tradition from scratch out of materials imported from continental Europe.

For Anderson, what disqualifies Williams from the canon of Western Marxism is not that there is a lack of basic correspondence. The omission is explained more simply and phrased as though uncontroversial: 'Williams's work ... has not been that of a Marxist' (1987, p. 105). What must then be noted is that Williams's engagement with Western Marxist ideas (as well as those of non-Marxist radical European traditions) intensifies in close conjunction with a) his increasing sense of his own Welshness and deepening antipathy towards England (and by proxy a certain England-centric image of Britain), and b) his sense of his own work as Marxist. These are contradictions, relative to the views of Anderson and others, that require analysis in the context of those critical responses. It is to this that I know turn, as part of a

\footnotetext{
${ }^{21}$ See p. 13 below.
} 
wider survey of critical responses, in addition to those already mentioned, to Williams's interactions with European thought.

\section{The Meaning of Williams's Europeanism: Critical Perspectives}

It seems there are no comparisons of Williams to continental Marxist thinkers prior to that of Gwyn A. Williams in 1960. Given the extraordinary lag between the publication of major Western Marxist texts in Europe and their translation and publication in Britain, ${ }^{22}$ this should not be surprising. In 1980, Williams would note the 'inordinate time' it took ideas to cross the Channel, 'one of the longest cultural journeys in existence by comparison with the physical distance' (1989n, p. 78). Two important intellectual events in the sixties structurally prefigure much of the subsequent critical debate: a) the shift from the 'first' to the 'second' generations of New Left Review, ${ }^{23}$ in which Williams played a significant role and b) the publication of the 'Nairn-Anderson theses', a body of work ${ }^{24}$ which provided the catalyst for British debates over the relative strengths and weaknesses of British and European socialist thought. The original $N L R$ would last only two years, in which brief period Williams contributed six articles. From 1963 and with a new format from 1964, a younger generation of editors around Perry Anderson, Tom Nairn and Robin Blackburn would steer the journal in a quite different direction. Fred Inglis (1995) provides a concise account of Anderson's new vision:

Anderson had flinty views on what to do with the Review. He would ditch the uneasy mixture of up-to-date journalism, CND and anti-Tory polemics, investigative exposures and movie reviews, ULR moralising and New Reasoner economics. The new version of the review would be a trans-continental and trans-Atlantic journal of neo-Marxist theory with a strongly revisionist turn, taking its lead from Sartre and Louis Althusser, a name then barely known in Britain, from early Marx and the unheard of Italian, Antonio Gramsci. It would keep faith with the cultural emphasis that had made its signature, and which carried Williams's unique authority, but attach it to a more exigent and rigorous sociology than the old Marxist historians had ever read. Weber would be as much cited as Bernstein, Levi-Strauss as Engels. (1995, p. 185)

While ostensibly concerned with many of the same issues (culture, the rise of "consumer society', the legacy of Stalinism, the question of revolutionary agency), the 'second generation' of NLR set their intellectual sights squarely beyond British borders, courting the

\footnotetext{
${ }^{22}$ See pp. 30-32.

${ }^{23}$ New Left Review was created in 1960 as a merger of the editorial boards of The New Reasoner (John Saville, E.P. Thompson and Ralph Miliband) and Universities and Left Review (Stuart Hall, Charles Taylor and Raphael Samuel). While not an editor, Williams regularly contributed articles and, as Ellen Meiksins Wood (1995) recounts, he was 'brought into the planning of the new journal very early' (p. 25).

${ }^{24}$ See Forgacs (1989), p. 74, for a full list of the texts.
} 
most contemporary continental Marxist theory. The formal editorial shift was fractious, effectively a purge by Anderson of several members of the old board, including Thompson, who responded by attempting a counter-purge. In conversation with Inglis, Anthony Barnett, another member of the board, recalls that Thompson attempted to enlist Williams in ousting the younger editors, but he refused (Barnett quoted in Inglis, 1995, p. 186). The disagreement was not bitter enough to stop Williams and Thompson collaborating on the May Day Manifesto, nor in keeping up a friendly personal correspondence. It was the spark, however, for what would be a long rivalry between Thompson and Anderson.

The 'meaning' of Williams's work is an element of contestation within the works comprising Thompson and Anderson's rivalry, and several commentators have noted the ambivalent relation borne by Williams to each camp. Wood, a Thompsonite critical of the second generation of $N L R$, suggests that Williams makes an interesting witness because 'he never neatly fitted into either group and for that reason could be seen as bridging them' (1995, p. 25). Inglis (1995), similarly, frames Williams's role as a personal, mediatory intervention in an intellectual dispute between the 'first' and 'second' New Lefts. ${ }^{25}$ Barnett (in Inglis, 1995) puts Williams's refusal to block Anderson's reforms down to an instinct for 'survival' (p. 186), a desire to avoid NLR suffering the same fate as his own short-lived journal Politics and Letters (1947-48). Inglis and Barnett's comments also suggest that Williams, in rebuffing Thompson, was demonstrating a closer theoretical affinity to the younger generation. This is very difficult; one of the aims of this thesis is to establish Williams's position relative to these opposing stances on the salience of European Marxism to British socialist thought. This is not to say that Williams's only differences with Thompson concern his 'Europeanism', or that his only differences with Anderson et al concern his 'Britishness'. The real divisions between tendencies within the New Left were far more complex than any single explanatory axis can capture, and are beyond the scope of this thesis.

It will be worth briefly summarizing the historical and theoretical debate around which the critical reception of Williams's Europeanism has orbited. Anderson and Nairn set out their theoretical critique of British radical traditions in a series of historical essays in $N L R$. The opening salvo was Anderson's ‘Origins of the Present Crisis' (1964), published alongside

\footnotetext{
${ }^{25}$ Inglis (1995), using interviews with some of the participants in this debate, provides a particularly thorough account.
} 
Nairn's 'The English Working Class' ${ }^{26}$ (1964). The basic argument of these ambitious texts was that Britain's lack of a classic revolutionary break from feudalism severely impacted the intellectual development of both bourgeoisie and proletariat. Untethered from the demands of revolution, Britain's bourgeois-feudal ruling class never had to develop an overarching, heroic revolutionary theory to justify its hegemony and, in consequence, Britain lacks a systematic, rationalist tradition. British intellectuals, both bourgeois and proletarian, have tended towards empiricism, favouring the tangible and fragmentary (particular) over the intangible and structural (universal). A near-total lack of 'totalising' theory rendered the English working-class corporative, rather than hegemonic in outlook, reliant on nonrevolutionary theories like utilitarianism (Fabianism). When Marxism finally arrives from the continent, it is 'too late'; there is a lack of serious intellectual labour to 'translate' the totalising, rationalist perspectives of Marxism into terms that make sense to 'the English mind'. Britain, then, lacks either a classical sociology or a national Marxism i.e. either an idealist (bourgeois) or a materialist (Marxist) theory of society as a totality.

Anderson explicitly singles out Williams's Culture and Society as an example of analysis which fails to distinguish between 'corporative' and 'hegemonic' forms of working-class culture and strategy (1964, p. 44). Now, Williams had argued that the solidaristic and communal culture of the working class could be generalised as a 'common culture' compatible with socialist goals; ostensibly, this is a hegemonic vision. Williams would later come to realise that this approach was guilty of a false universalism, the imposition of the culture of one specific kind of community (that of his own Welsh working class roots) onto society as a whole. ${ }^{27}$ Anderson's criticism is different: Williams's 'common culture' could never be hegemonic because it proceeded from the experience of a class with an over-defined sense of itself. The British working class, Anderson argued, knew only its own experience and, lacking any conception of the social totality, was ignorant of the practices and forces which would need marshaling for it to achieve power. The British labour movement needed to become acquainted with the kind of totalising reason that had found socialist expression in Marxism in Europe, but had failed to break through the empiricist armour ingrained into British culture by historical events. Williams, as it would turn out, would become perhaps the

\footnotetext{
${ }^{26}$ The title of Nairn's piece may have been a materialist rejoinder to the implication buried in the title of Thompson's The Making of the English Working Class, namely the 'culturalist' position that a national working class does not exist 'in itself', but must be 'made' in the course of its experiential development.

${ }^{27}$ See Chapter Two.
} 
foremost advocate of the 'perspective of totality' in Britain. His conception of totality, however, would not rely on the rejection of experience.

Thompson (correctly) read Nairn and Anderson's pieces as attacks on his The Making of the English Working Class (1963). His acerbic rejoinder, 'The Peculiarities of the English' (1965), claimed that Anderson and Nairn were 'model-builders' (p. 321), substituting abstract theoretical models for real, fine-grained historical analysis. Thompson defended what he agreed with Nairn/Anderson is a native English empiricism by contrasting it with the kind of ahistorical abstraction he believed the younger historians to be engaging in. For Thompson, empiricism was to be lauded as concomitant with scientific enquiry in general, as that which confirms hypotheses and grants the validity of any abstract model (p. 337). A member of the dissident Communist Party Historians Group, Thompson wanted to emphasize the strength of a native Marxist tradition as a means of distancing British Marxism from the Moscow line. ${ }^{28}$ Nairn and Anderson's dismissal of any native British Marxist tradition is thus read as dismantling Britain's only line of defence against the anti-humanism of orthodox communism in continental Europe. What is at stake here is the contested status of British intellectual traditions within the broader post-Stalinist reconceptualization of socialist internationalism. In both Thompson and Anderson/Nairn's work there is a sense of necessary reorientation, but in different directions. For Thompson: inwards, in search of the seams of national strength and authenticity that might ground a more durable internationalism in the future. For Anderson/Nairn: outward, against both the traditions of a native imperialism and the 'Foreign God that Failed'. Williams's own reorientation, as well shall see, contains elements of both.

Anderson's furious rejoinder to Thompson, 'Socialism and Pseudo-Empiricism' (1966), laid the groundwork for the more systematic critique of British intellectual culture in 'Components of the National Culture' (1968). Williams figures in both these texts in interesting ways. The key thesis is stated earlier in the 1966 text: 'Britain never produced either a Marxism or a classical sociology' (p. 22). What it did produce, however, was a relatively totalising literary and literary-critical tradition. Uniquely, in Britain, argues Anderson, it was literary criticism that came closest to adopting a totalising view; Anderson (1966) praises Williams's critical work alongside these exceptions to Britain's dire intellectual record:

\footnotetext{
${ }^{28}$ See Hamilton (2011), pp. 93-132, for a more detailed account of Thompson's grievances against Anderson and Nairn.
} 
The achievement of the English realist novel is a rare pinnacle in any comparative perspective. Indeed, as I remarked in Origins of the Present Crisis, it is precisely in a cognate literary tradition that the Victorian intellectuals came nearest to a philosophical vision and critique of their society - the subject-matter of Culture and Society. The issue, however, is whether these intellectuals produced a total political vision of society of the same quality or coherence. The indisputable fact is that they did not. (1966, p. 17)

It is immensely significant, incidentally, that the only major theoretical departure in English social thought in the last decade - The Long Revolution - has derived from a writer trained in literary criticism. This was perhaps the only source from which it could have come, since the literary tradition of Culture and Society was the British substitute for classical sociology or a philosophical socialism in the $19^{\text {th }}$ century. (1966, p. 23)

Williams, on this analysis, is the only contemporary 'English' thinker to break free from his 'native' empiricism, and to embrace a totalising, quasi-sociological perspective on social relations. The prevailing sense among commentators had been that Williams was indeed an 'empiricist', consistently privileging experience over structural modeling and abstract reason; Anderson's view is thus a dissenting one. It is explained by the concept of totality, the conceptual lodestone which Anderson correctly takes to be the crucial meeting-point between Williams and the Western Marxist tradition which he and Nairn were aligning themselves with in the sixties.

Thompson had implicitly accused the younger historians, due to their apparent anti-empiricist disregard for historical 'detail' and subjective experience, of recapitulating the anti-humanist logic of orthodox communism. In 'Socialism and Pseudo-Empiricism', however, Anderson (1966) rejects Thompson's critique and claims an unorthodox, transnational Marxist tradition:

The theoretical lineage of our work is altogether different from Thompson's image of it. It comes from the major tradition of Western European Marxism since the First World War - a tradition which has consistently been coeval with new forms of idealism, and a dialectical response to them within the evolution of Marxism itself. This distinctive movement has produced a Marxism which has always had an 'idealist' dimension, by the canons of Engels or Kautsky. There have been three decisive moments in this complex history. In the early 1920's, Lukacs, formed in his youth by Hegel and the neo-Kantians, Dilthey, Lask and Simmel - synthesized these influences with his new-found Marxism and produced Geschichte und Klassenbewusstsein. In the 1930's Gramsci, imprisoned in Italy, reworked the philosophy of Croce and De Sanctis (themselves descendants of Hegel) into a novel and labile Marxism, which started from a 'theory of the superstructures'. In the fifties and early sixties, Sartre - whose immediate intellectual ancestors were the existentialist Heidegger and the phenomenologist Husserl - reinterpreted the whole 
trajectory of his own work and wrote the massive treatise which dominates Marxist discussion today, the Critique de la Raison Dialectique. (1966, p. 31)

Most importantly for our purposes, the three thinkers Anderson aligns himself with here (Lukacs, Gramsci and Sartre) are precisely those whom Williams (1972) will describe as Marxism's 'alternative tradition', a lineage which this thesis argues was centrally formative of his mature cultural materialism. Notice also that the Marxist tradition Anderson is laying claim to consists of a) thinkers who are, like Williams, thinkers of the totality i.e. of society as a set of mutually constitutive relations and b) thinkers who, again like Williams, develop a materialist position from within idealist traditions (Anderson knows he has a solid precedent for this in Marx's Hegelian roots). The role Anderson then projects for Williams is as something like the progenitor of a late-coming, 'native' British Marxism tasked with overcoming the bankruptcy of its own intellectual inheritance. Working from the proposition that 'it is virtually certain that any creative Marxist theory in England will follow the [European] pattern' (1966 p. 32) he had described, Anderson implicitly portrays Williams as the British equivalent of the idealist precursors of the Western Marxists, the Dilthey, Husserl or Croce of an embryonic British, or rather English, Marxism: 'For the most advanced socialist thought in England is Raymond Williams's superbly intricate and persuasive work itself the most generous and humane idealism we have yet known. Any English Marxism will have to measure itself against this landmark in our social thought; it will only emerge from a real dialogue and communication with it' (p. 32). ${ }^{29}$

A fascinating dynamic in Anderson's assessment is that he appeared to view Williams as both the saviour and as the most powerful critic of the British intellectual tradition. Inglis (1995) has the right sense of this: 'Needing as a matter of urgency a home-bred theorist who could rescue old English inertia (the essay is powerfully, but of course implicitly, patriotic), Anderson found one in Raymond Williams' (p. 218). Anderson's elevation of Williams, then, has at its root a kind of patriotism. Anderson wants to save England from itself, from its own history, but the paradox of his approach is that while he cannot imagine the British tradition itself offering much of use, he also cannot imagine a 'British Marxism' emerging merely from he and Nairn importing a foreign theoretical pantheon; this, ironically, had been Thompson's concern. There is then a further irony, which is that while one of the commonest

\footnotetext{
${ }^{29}$ Anderson (1968) would reaffirm this positioning of Williams in 'Components of the National Culture', arguing that from within the native tradition of literary criticism, heretofore dominated by the 'mystified form' of the (conservative, organicist) totality in F. R. Leavis, 'Williams was able to develop a systematic socialist thought, which is a critique of all forms of utilitarianism and Fabianism - the political avatars of empiricism in the labour movement' (p. 56).
} 
critiques of Williams was his 'insularity', or even his 'cultural nationalism', Williams was actually far less concerned than either Anderson or Nairn with the production of a specifically British (much less English) Marxism or materialism. He was, in this sense, the more consistently transnational thinker.

I have already mentioned Nairn's harder critique of Williams's 'cultural nationalism', which was spurred by Williams's initial refusal to register a view on the question of Britain's accession to the European Community. Williams, Nairn believed, was cleaving to the British (bourgeois) nation-state. But, as Barnett (1976) would later recount, 'when the referendum came round in 1975 and Williams could no longer refuse to register, he drew exactly the conclusion that Nairn thought he would not ... Williams voted for entry into Europe, as a socialist' (p. 52). This, of course, was the period of a burgeoning Welsh nationalism which, as I have already argued, was connected to Williams's Europeanism by a thread of trenchant critique of the dominant English culture and the British state. Barnett intuits something similar: 'Far from clinging to it, he began to break away when international developments ${ }^{30}$ after 1968 made this more possible, until when the referendum came round he chose a "West European" identity' (p. 52). But by neglecting the Welsh dimension of this shift, Barnett misses an opportunity to assess Williams's increasing commitment to cultural pluralism, in effect reducing a complex development to a simple pivot towards Europe. I address this point in considerable detail in Chapter Two.

Like Nairn, the young Eagleton failed to perceive the scale of Williams's reorientation in the seventies, portraying his oeuvre, including the late cultural materialism, as irrecoverably immersed in an English tradition. By the time of his 'Criticism and Politics' (1976). NLR had practically achieved its goal of bringing Western Marxism to a British academic audience. Althusser had arrived and, for the young Eagleton, had superseded the residual idealism of the earlier Western Marxists with a more rigorous and scientific approach, grounded in a structuralist and anti-humanist redeployment of historical materialism. At the core of Eagleton's critique was complex a more rigorously anti-humanist version of the NairnAnderson theses. Thus it is Williams's 'insistence on experience, this passionate premium

\footnotetext{
${ }^{30}$ The international developments Barnett alludes to are presumably the popular uprisings of May 1968 and the shift towards Eurocommunism of some European communist parties in the wake of the Soviet invasion of Czechoslovakia. But there was also, of course, a major domestic reason for re-orienting towards Europe: the failure of the first Wilson Labour government to push through the contradictions of the 'new capitalism' towards a socialist future for Britain, a failure which had already been diagnosed by Williams, Thompson and Hall in the May Day Manifesto (1967).
} 
placed upon the "lived", which provides one of the centrally unifying themes of Williams's oeuvre - which supplies at once the formidable power and drastic limitations of his work' (1976, p. 8). Williams's work is fatally limited, then, by his 'native' empiricism and humanism but, interestingly, Eagleton also provides the first explicit comparison of Williams to named Western Marxist thinkers since Gwyn A. Williams's Gramsci allusion:

The English Marxism available to [Williams] was little more than an intellectual irrelevance; indeed if a Marxist criticism comes about in English society, one might risk the paradox that one of its sources will be the fact that Williams had in his own time to reject it. What he did, then, he did almost single-handedly, working from his personal resources, without significant collaboration or institutional support. The product of this unflagging, unswerving labour was the most suggestive and intricate body of socialist criticism in English history - criticism for which no English comparison is even remotely relevant, but which must be referred for comparative assessment to the aesthetic production of a Lukacs, Benjamin or Goldmann. It is enough to say that any Marxist criticism in England which shirks taking the pressure of Williams's work will find itself seriously crippled and truncated. (1976, p. 9)

Eagleton, unlike Thompson, Nairn and Anderson, is writing from within the same discipline as Williams; the goal is not an English Marxism tout court, but an English criticism. Thus Eagleton's European comparisons are thinkers with a prodigious literary-critical or 'aesthetic' output $^{31}$. Note that he does not make statements of influence but of comparative impact or achievement. Eagleton will grant biographical and thematic similarities between Williams and Lukacs, but he will not grant a serious influence. Indeed, Eagleton's primary criticism of Williams's late engagement with European theory is that Williams looks only with 'a certain proprietary interest to Europe, to find echoes of his own independently-produced work reflected back to him' (1976, p. 18) Rather than being actively influenced by Western Marxism, then, Eagleton takes Williams to be appropriating European theory to ends which are fundamentally those of an irreducibly British empiricism. Barnett's (1976) rebuttal is more an apologia for the parlous state of British Marxism during Williams's formation than of Williams himself. While Eagleton attributes the absence of a strong post-war Marxism to a British intellectual tradition incapable of 'thinking' historical materialism (the tendentially idealist nature of Eagleton's own position should be clear), Barnett attributed it to the predominance of authoritarian and pessimistic communism abroad. Ultimately, Eagleton and Barnett's disagreement on the historical logic of British socialism is secondary, for both agreed that Williams is not in any serious way an international thinker. They agreed,

\footnotetext{
${ }^{31}$ Benjamin, a secondary European influence on Williams to whom he had not previously been compared, would be the central figure of Eagleton's Walter Benjamin or Towards a Revolutionary Criticism (1981), from which the 'British equivalent of Lukacs' phrase comes.
} 
furthermore, that Williams's apparent lack of European influence left him dependent on a defunct British empiricism: 'It can be said that, although he approaches experience in a historical and materialist fashion, the use to which Williams puts his notion of "experience" does not share these qualities. On the contrary it is given a privileged role as the determining organizer of knowledge' (Barnett, 1976, p. 62).

This thesis will argue that Williams's deployment of the notion of totality is an attempt at synthesising the insights of empiricist and rationalist modes of analysis. Recall that Anderson had viewed totality as the integration of various forms of historical, economic and cultural investigation, so as to 'make whole' social analysis. Williams concurred but, in addition, viewed the divisions between individual and society and between consciousness (or experience) and reality as examples of the fragmentary perspective which it was the task of totality to integrate. For Williams, fusing these oppositions was the great achievement of Sartre's late opus, The Critique of Dialectical Reason (French: 1960, English 1976) which, as I discuss in Chapter Two, was a key influence on Williams in the mid-seventies. Barnett (1976) makes an early, biographical comparison between Sartre and Williams in the NLR rebuttal:

While Eagleton properly insists that Williams's criticism should be compared with that of Lukacs, Goldmann and Benjamin, his political role can be contrasted with Sartre's. At first sight no two figures might appear more dissimilar, but there are some striking parallels between the two. Both have worked on the relationship between politics and culture, especially literature. Both have written novels and plays as well as criticism and social theory. Both are fascinated by the heroic period of the 1940s. Both have tried to become materialists on their own terms, fighting an obstinate battle against the reductionism of mechanical materialism. Had Politics and Letters survived, rather than flickering out, after a year of publication, in 1948, it would have been the English cousin of Les Temps Modernes. (1976, p. 64)

This is right, and the connection between the two journals may be closer than Barnett realises: one of Sartre's pieces in Les Temps Modernes, 'What is Writing?' (1947) ${ }^{32}$, appeared in translation in Williams's Politics and Letters (1947). This was the first English translation of the text; it is likely that Williams, who could read and write French, was the translator. That Williams found the piece valuable suggests a deeper connection to Sartre's work than Barnett's largely biographical comparison allows. The critical literature in general is egregiously silent on the link between Williams and Sartre. I attempt to remedy this in Chapter Two.

${ }^{32}$ This would later form the first chapter of Sartre's What is Literature? (1948). 
The gulf between the first and second New Lefts, which widened during the seventies under the influence of Althusser, was articulated around three seemingly irreconcilable oppositions: Britain vs. Europe, empiricism vs. rationalism and culturalism vs. structuralism ${ }^{33}$. Thus Thompson, the most vociferous defender of British culture and radicalism during the period, writes the most sustained British attack on a European Marxist with his The Poverty of Theory (1978). Anderson, while not an Althusserian, sees it as his responsibility to defend the broadly structuralist, 'Europeanist' and rationalist position in his Arguments Within English Marxism (1980). The nature of Williams's Marxism is again contested in these texts, with Thompson broadly aligning him with the first terms of the above oppositions, Anderson the second. Centrally, Thompson claims Williams as an ally against hard-Althusserian versions of 'determination':

The critical concept (unexamined by Althusser) is that of 'determination' itself; hence the importance - as Williams and I and others have been insisting for years (and to the deaf) of defining 'determine' in its senses of 'setting limits' and 'exerting pressures' and of defining 'law of motion' as 'logic of process.' This helps us, at once, to break out of the idealist circuit; we can no longer offer social formations as 'society effects' or as 'developed forms' of an immanent mode. (2013, p. 214)

Indeed, a central tenet of Williams's mature cultural materialism was that law-like versions of material determination and cultural production, whether of the base/superstructure or class/ideology variety, were inadequate, and that a more variegated approach was needed. Anderson grants this in his Arguments, but then points out that Williams at least critically entertained Althusser's more subtle notion of 'over-determination' in Marxism and Literature. He goes on to argue that Williams is one inspiration, Althusser the other, for the complex Marxist model of determination outlined by Erik Olin Wright in his structuralist classic, 'Class, Crisis and the State' (1978). We should note that Anderson is not appropriating Williams for Althusserianism; he is disputing the strict affiliation which Thompson imagines him to have to an 'English empiricist' Marxism. As further evidence, Anderson contrasts Williams's clear statement of affinity with Western Marxism in Marxism and Literature with Thompson's on-going disdain for European theory: 'The "unendurable time for a rational mind in the Marxist tradition" [TPOT] here becomes "the first" in which such a mind "could feel at home" $[M L]$. Experience, touchstone of the Thompsonian world, reveals its waywardness' (1980, p. 130).

\footnotetext{
${ }^{33}$ This last opposition forms the basis for Hall's 'Cultural Studies: Two Paradigms' (1980), in which he links Williams to a broadly Gramscian (culturalist), rather than an Althusserian (structuralist) paradigm.
} 
Now, while Anderson (1980) is right to emphasise the 'antithetical' (p. 130) character of Williams and Thompson's responses to European Marxism, he is wrong to oppose Williams's Europeanism to the notion of experience. A broadly empiricist methodology, focussing on lived experience as central to art, culture and politics, remained the hallmark of Williams's work throughout his life, even under the influence of European, 'rationalist' Marxism. In this sense, Williams was nearer to Thompson. While Williams's work in the sixties and seventies cannot be read as a conscious attempt to bridge the first and second New Lefts, enabling a dialogue between them, however fractious, became its theoretical function, given the real cleavages within post-war British Marxism. But Williams's position had always contained something of this synthesising impulse. His trademark concept of a 'structure of feeling' was an early attempt to reconcile experience with the sociological abstraction required to analyse society as a totality. Later this would morph, under the influence of Gramsci, into an empiricist reformulation of hegemony which emphasised the residual and emergent experiences which coexist in social space alongside the dominant culture. I present a theory of Williams's ‘empiricist Gramscianism' in Chapter Three.

The publications of Marxism and Literature (1977) and PL (1979), in which Williams engaged more closely with European thinkers than in his previous work, meant that critics in the eighties were more comfortable making comparisons and, occasionally, claims of influence. Hall (1980) acknowledged Williams's considerable late debt to Gramsci while critiquing his application of Gramscian concepts from a more structuralist perspective. J. P. Ward (1981), in the first book-length treatment of Williams, emphasised his Welsh Europeanism and correctly positioned him on the Gramscian rather than the Althusserian side of the debate around the nature of totality. John Higgins (1983), noticing the tautology evident in in Althusser's notion of a subject which is both interpellated and produced via interpellation, convincingly defended Williams's critique of Althusserian anti-humanism. Edward Said (1983) ${ }^{34}$ saw a kind of culturally mobile lineage from Lukacs, through Goldmann to Williams while Mulhern (1984) noticed the value of Williams's (2005d) writings on the East German Marxist Rudolf Bahro. Jan Gorak (1988), with Said and against Eagleton, acknowledged the real influence of Goldmann and paired the French Marxist with Mikhail Bakhtin as important figures for Williams's mature thought.

\footnotetext{
${ }^{34}$ See Chapter One, pp. 78-85 for a fuller discussion of Said's thesis.
} 
Williams's untimely death in 1988 instigated a flurry of critical appraisals. David Forgacs (1989), continuing Gwyn A. Williams's now venerable line of thought, perceived a Gramscian thematic not just in Williams's early work, but also in that of Thompson, Anderson and Nairn. Eagleton, while not withdrawing his past criticisms, took a more conciliatory and respectful tone towards Williams in his edited collection Raymond Williams: Critical Perspectives (1989). Here Eagleton (2007a) reads Williams as actually anticipating more recent European developments (specifically: Bakhtinian social linguistics and Habermas's theory of communicative action) and argues that Williams wisely avoided the hard Althusserianism and post-structuralism then tempting literary scholars (including Eagleton). In the same volume, Fernando Ferrara (2007) situates Williams as a significant contributor to European intellectual life. He recounts that Williams visited him and his colleagues in Italy 'to cooperate in a project we had designed to support the introduction of cultural studies into the English curriculum of our university' (p. 97). Like other critics, Ferrara makes Gramsci central to Williams's thought, but he also signals the importance of Williams to Italian scholarship:

Hegemonization was the longest revolution; ${ }^{35}$ it is in fact a never-ending revolution. This doctrine at once authenticated and added new drive to [Williams's] own ideas. If Gramsci can be considered an authority in the field of cultural studies, then this is what Italian cultural studies have contributed to Raymond Williams as a cultural thinker. Perhaps it is not accidental that when he wrote Problems of Materialism and Culture (1980) and Culture (1981) his books were promptly translated into Italian and acknowledged as participating in an international discussion that went back to Tocqueville, Marx and Weber and extended to Gramsci, Lukacs, Brecht and Goldmann. (2007, p. 105)

Central to Ferrara's essay is a sense of mutual constitution: Gramsci provided Williams with the conceptual tools to develop his work within and beyond a British tradition, and Williams was now bringing the perspectives of British cultural studies to Italy, helping Ferrara and his colleagues to 'break up the dominance of Crocian, neo-idealist attitudes still rampant in the [Italian] academy, especially in literary studies' (p. 97). Anderson (2016) would later remark that it took a British intervention, namely that of Williams, to rescue Gramsci from his sterilization (p. 76) at the hands of the Italian Communist Party (PCI). Ferrara (2007) doesn't go as far in critiquing the PCI, but he does note that Marxist literary theorists had tended to follow the PCI's orthodox, 'base to superstructure' line and were unready to accept arguments about 'cultural revolution' (p. 102). In another crucial parallel between Williams

\footnotetext{
${ }^{35}$ In Chapter Three, pp. 206-223, I build on a variant of Ferrara's position, linking the notion of a 'long revolution', to what Gramsci described as a 'war of position'.
} 
and a Western Marxist, then, both Britain and Italy were 'unready', in the post-war period, to receive the insights of their respective 'culturalists'. When one broke through, so did the other; in both countries, a growing receptiveness to either Gramsci or Williams appears to have facilitated receptiveness to the other.

At the centre of Tony Pinkney's readings of Williams in this period is a recuperation of Williams as a modernist or even a postmodernist; anything but the 'British Lukacs'. The 'British Bloch' argument comes from his contribution to Eagleton's critical collection, but the ascription of postmodernism to Williams comes from Border Lines (1991), a study of Williams's novels. There Pinkney describes Williams as a 'postmodern novelist', and as developing from a realist into a postmodernist over the course of his career. As will be clear from Chapter One and the conclusion to this thesis, I take Eagleton's side in the realism/modernism debate as it relates to Williams. Briefly, I believe novels like The Volunteers (1978) and The Fight for Manod (1979) are better served by David Harvey's (1995) reading, that they evoke 'the battle between different levels of abstraction, between distinctively understood particularities of places and the necessary abstractions required to take those understandings into a wider realm, the fight to transform militant particularism into something more substantial on the world stage of capitalism' (p. 85), than by Pinkney's (1991) evocation of 'impossible totalities' (p. 109), 'the Lyotardian postmodernist sublime' (p. 108) or 'the impossible nature of postmodern, multinational space' (p. 108). I read Williams as a realist not only in his aesthetic preferences and literary-critical insights, but also philosophically. Eagleton's accurate observation that Williams avoided the lure of postmodernism is grounded, I think, in the recognition that Williams remains within a realist problematic; he maintains a space for thinking through the nature of objective reality. 'Representation' and its paradoxes are not, as Pinkney comes close to arguing, the horizon of Williams's thought. Williams's few engagements with the major postmodernists (Derrida, Foucault, Lyotard), as well as Lacan ${ }^{36}$ and the feminist psychoanalysts of the seventies and eighties were scant and insubstantial, tending towards the dismissive.

\footnotetext{
${ }^{36}$ The most positive statement on Lacan, which is really a critique of his academic use, is the following from Politics and Letters (2015 [1979]): 'I have great respect for Lacan, but the totally uncritical way in which certain of his concepts of phases in language development have been lifted into a theoretical pediment of literary semiotics is absurd, in a world in which there is current scientific work of a non-philological kind with which all such concepts have to be brought into interplay ... What is needed is not a blending of concepts of literature with concepts of Lacan, but an introduction of literary practice to the quite different practice of experimental observation. That would be the materialist recovery' (p. 341).
} 
Pinkney's intervention is indicative of a brief period in which several critics sought either to align Williams with figures linked to post-structuralism or, in stark contrast to the preceding period of critical reception, to critique him for being too Marxist. Thus Simon During (1989) reads Williams's decentralist politics as a possible influence on Laclau and Mouffe's postMarxist classic Hegemony and Socialist Strategy (1985) and distances Williams from Bourdieu and Sartre in favour of Maurice Blanchot (the latter a significant influence on Derrida, Foucault and Deleuze). Alan O'Connor (1989) makes an oblique comparison to Merleau-Ponty and notes some differences with Sartre on ethics. ${ }^{37}$ Michael Moriarty (1992), recalling Williams's contention that 'a fully historical semiotics would be very much the same thing as cultural materialism' (Williams, 1984, p. 210), argues for a theoretical rapprochement between cultural materialism and structural linguistics; Jon Thompson (1993), likewise, sees a fruitful connection between Williams on literary form and Barthes's ecriture. On the more concretely anti-Marxist side of things, Robert Miklitsch (1995) argues that Williams's 'characteristically proletarian, neo-Gramscian' (p. 86-87) reworking of hegemony is inferior to Laclau and Mouffe's which 'better enables one to think the dispersion, fragmentation, and indeterminacy of our postmodern moment' (p. 87). In a similar vein, John Brenkman (1995) argues that Williams, however 'dissident' he may seem relative to orthodox Marxism, nevertheless remains too attached to the working class and lags, conceptually, behind the Austrian social philosopher Andre Gorz, whose insights 'would have sharpened Williams's sense that the task of the democratization of culture and the struggle for socialist institutions was proceeding through new social movements that certainly traversed but could never unite the working class' (p. 265).

The minority of more post-structuralist oriented views above speak to the relative weakness of academic Marxism and class politics in the immediate post-Soviet years. Harvey (1995), whose views of Williams's novels I contrasted favourably to Pinkney's, restores Williams to a Marxist critical framework, noting his crucial affinity to Brechtian humanism and the message of his plays, that 'the ways in which personal and particular choices made under given conditions are the very essence of historical-geographical change' (p. 79). But it is John Higgins's Raymond Williams: Literature, Marxism and Cultural Materialism (1999) which most explicitly positions Williams within the Western Marxist tradition:

\footnotetext{
${ }^{37}$ O'Connor, noting the publication in Williams's Politics and Letters journal of a piece by Sartre (see Chapter Two of this thesis for further discussion), says: 'The Politics and Letters editorial description of the institution of literature as human responsibility is a very different vocabulary from Sartre's existentialism' (p.13). From the general vocabulary of existentialism, perhaps, but not from Sartre's larger account of 'committed' writing in What is Literature? (2001). In Chapter Two, I compare the 'literary ethics' of Williams and Sartre.
} 
Certainly, The Country and the City (1973) and Marxism and Literature (1977) are usually regarded as key works in the Western Marxist tradition of cultural and aesthetic theory. With Georg Lukacs and Lucien Goldmann, Williams shared a commitment to teasing out the relations between history and form; alongside Sartre and Gramsci, he explored the ideas of commitment and hegemony; like Benjamin, Brecht and the Frankfurt School, he sought to understand the dynamics of contemporary cultural expression. Throughout his career, he argued for a better understanding of the constitutive force of culture in social reproduction than orthodox Marxist theory appeared to allow, or, to frame his achievement differently (and this is the turning point for Marxist assessments of Williams), he overestimated the force of culture in social reproduction in ways which exemplify the left-idealist tendencies of Western Marxism. (1999, p. 100)

I suggest two caveats to this otherwise correct assessment. First, 'usually' is too strong; while Williams's debt to Western Marxism has been increasingly acknowledged, there has always been an equal, and in the post-war decades clearly dominant, tendency to distance him from it. Secondly, while it is true that Williams's work has often shared weaknesses with the 'leftidealism' of some Western Marxists, this is decreasingly the case as Williams matures and cannot properly be said of the later developments. My position on Williams's late work is closer to Fowler's (2000), who argues that both Williams and Bourdieu sought to forge new methods which were 'determinist but not economistic' (2000, p. 110), that is, which avoided the pitfalls of both vulgar materialism and the idealist paradoxes of much Western Marxist thinking.

The question of whether Williams can finally be called a 'culturalist' animates much of the critical discussion around his work. Andrew Milner's innovative analysis in Re-Imagining Cultural Studies (2002) begins from the proposition that cultural studies was always a transnational phenomenon, emerging from the tripartite intellectual foment of German critical theory, French structuralism and 'Cambridge English'. Milner then argues for a 'going beyond' of British culturalism in Williams, comparable to Habermas, Foucault and Bourdieu relative to their respective national 'schools':

In short, Williams stands in an essentially analogous relation to the culturalist tradition as does Habermas to the (Western) Marxist, Foucault and Bourdieu to the structuralist. Williams's cultural materialism is thus best understood, neither as a culturalism nor even a left-culturalism, but rather as what we have termed 'postculturalism'. We have noted how the theoretical literature in Cultural Studies tended to contrast Williams's 'culturalism' with the long tradition of French structuralism. What we now know as post-structuralism developed by way of a reaction against precisely this structuralist intellectual tradition. But there is an equivalently long culturalist tradition behind Williams, reaching back from Eliot and Leavis to Arnold 
and beyond. And Williams's relation to this tradition is essentially 'post-culturalist' (2002, pp. 169-170)

Milner acknowledges the significant theoretical differences between these thinkers, but his point is a relative one: Williams does for the Culture and Society tradition what Habermas does for the Frankfurt School and Foucault and Bourdieu, in different ways, do for French structuralism. But what is the substance of this comparison? Milner's analogy seems to be based upon what might be termed 'postmodernization'; thus in each thinker there is a 'relativizing turn' i.e. away from their respective 'modernist' traditions, an acknowledgement of the 'intrication of power in discourse' and a sense of 'genuinely free communicative action' (p. 170). I would argue, however, that at the root of Williams's realism lie commitments a) to some form of objective material and social reality and b) to forms of community which, in being materially structured by a common experience, are precisely nonrelativistic. As Daniel Williams (2003) points out, Williams's late cultural pluralism 'cannot be unreservedly aligned to the views of postmodern hybridists, for Williams's pluralism always involves a simultaneous gesture towards a community of belief and action which is hardly compatible with the cultural and political relativism of postmodernism' (pp. xlivxlv). ${ }^{38}$ 'Post-culturalist' may be a serviceable term, but Milner's analysis suffers from the assumption that the only way to be 'post' something is as the agent of its postmodernization. In this thesis I offer a different perspective on how Williams may be read as a 'postculturalist', rooted in my sense of him as a realist. Milner is right, of course, to emphasise that the discipline of cultural studies, as the 'father' of which Ferrara invited Williams to lecture in Italy, was the product of a thoroughly transnational and Europeanist foment.

Paul Jones's ambitious Raymond Williams and Sociology: A Critical Reconstruction (2004) is the most thorough-going attempt to rescue Williams from the 'charge' of culturalism, aligning him with a modern, sociologically-inclined Marxism. Briefly, Jones reads Williams as engaged in a recalibration of Marxist cultural theory away from base and superstructure and towards an analogy with Marx's 'forces' and 'relations' of production. ${ }^{39}$ In exploring this, Jones enthusiastically asserts the influence of Western Marxist thinkers on Williams, paying more attention to the influence of Frankfurt School thinkers like Adorno, Benjamin

\footnotetext{
${ }^{38}$ See Chapter Two, pp. 180-192, for a thorough discussion of Williams's views on community and the politics of place.

39 At the core of Jones's assessment is a rebuttal of Eagleton and Hall's critiques of Williams's 'culturalism' as insufficiently Marxist: 'For it is evident that Williams resolves the arguably oxymoronic nomenclature, "cultural materialism", by an appeal to a Marxian paradigm of production. He makes plain that the cultural materialism is not driven principally by an extended philosophical elaboration of a "materialism" but, instead, by the application of this production paradigm to the field of culture' (p. 38).
} 
and Marcuse ${ }^{40}$ than most previous critics. Central to Jones's argument is that Williams doesn't simply discard thinkers like Goldmann and Benjamin in favour of Gramsci in the late seventies, but that the influence of those thinkers are retained; this is right and, as this thesis demonstrates, must also be said of Lukacs and Sartre. The influence of Adorno and Benjamin may be overstated in Jones's account, but his assertion of influence is welcome. Jones's core argument, that Williams's developed thought is sociology rather than culturalist 'immanent critique', is in many ways convincing.

In recent years, during what might broadly be described as the era of postcolonial theory, discussion of Williams has quite rightly begun to address Williams's relation to nonEuropean thinkers, ideas and formations. ${ }^{41}$ This is important not only because of the scholarly value in mapping such connections, but because 'critical theory' itself has undergone a significant geographical shift since Williams's death. In his book The Left Hemisphere: Mapping Critical Theory Today (2013), Razmig Keucheyan argues for a process he calls 'the globalization of critical thinking' (p. 20), in which broadly marxisant critical and cultural theory migrates away from Europe in the eighties, first to the Anglo-American academy, then more recently to 'the peripheral regions of the international intellectual field' (p. 20). Daniel Williams's Who Speaks for Wales? Nation, Culture, Identity (2003), in its close focus on Williams's relation to Wales's post-coloniality has been instrumental in promoting a concomitant shift within Williams studies. And again, in this new movement, Wales has functioned as a kind of key to relating Williams to the world beyond England, beyond Britain and now beyond Europe. This thesis, of course, is focussed on Williams's Europeanism, but it is important to emphasise the connectivity which a modern, 'globalised' critical consciousness may intuit or construct between Williams and an even more expansive transnational milieu.

\section{Williams and European Theory: An Outline}

Not for nothing did Williams describe the crossing of the English Channel as 'one of the longest cultural journeys'. A central mediating factor in Williams's reception of European thinkers is the lag between original and English publications of many key works of Western Marxism, as well as structuralism and psychoanalysis (less so for existentialism). In orienting ourselves to Williams's Europeanism, then, it will be useful to establish some key publication

\footnotetext{
${ }^{40}$ Mulhern (2009) has also discussed the hitherto unrecognized influence of Marcuse on Williams.

${ }^{41}$ See, for example, Dix, H. (2010), Masnatta, C. (2010) and Williams, D. (2003).
} 
dates. The selection of texts below is based on Williams's own published writings; Williams makes reference to all of the listed texts at some point in his career (this fact alone should dispel the notion that he was an 'insular' thinker).

Publication in English of key texts by Williams (in bold) and by relevant European thinkers (original publication dates in brackets):

1921 - Williams born

1941 - Fromm's The Fear of Freedom (U.S.)

1943-51 - Various of Sartre's plays published in English shortly after French publication 1947 - Sartre's 'What is Writing?' (French and English, the latter in Williams's journal Politics and Letters)

1950 - Lukacs's Studies in European Realism (German: various, thirties)

1950 - Reading and Criticism

1952 - Drama from Ibsen to Eliot

1954 - Preface to Film

1954 - Drama in Performance

1955/56 - Marcuse's Eros and Civilisation (German and English)

1956 - Marx’s Capital vol. 2 (German: 1885)

1956 - Sartre's Being and Nothingness (French: 1943)

1957 - Gramsci's The Modern Prince and Other Writings (Italian: 1950 but written 1929-35)

1958 - Culture and Society

1959 - Marx’s Economic and Philosophical Manuscripts (German: 1844)

1959 - Marx’s Capital vol. 3 (German: 1894)

1959 - Saussure's Course in General Linguistics (French: 1916)

1960 - Border Country

1961 - The Long Revolution

1962 - Lukacs's The Historical Novel (German: 1937)

1962 - Britain in the Sixties: Communications

1963 - Levi-Strauss's Structural Anthropology (French: 1958)

1963 - Lukacs's The Meaning of Contemporary Realism (German: 1958)

1963 - Sartre's Search for a Method (French 1957)

1964 - Marcuse's One-Dimensional Man published in German and English

1964 - Brecht's 'The Modern Theatre is the Epic Theatre' (German: 1930) 
1964 - Brecht's ‘A Short Organum for the Theatre' (German: 1948)

1964 - Second Generation

1966 - Modern Tragedy

1967 - May Day Manifesto

1968 - Drama From Ibsen to Brecht

1969 - Levi-Strauss's The Elementary Structures of Kinship (French: 1949)

1969 - Benjamin's ‘The Work of art in the Age of Mechanical Reproduction' (German: 1935)

1969 - Althusser's For Marx (French: 1965)

1970 - Althusser's Reading Capital (French: 1965)

1970 - The English Novel from Dickens to Lawrence

1971 - Gramsci’s Selection from the Prison Notebooks (Italian: 1950 but written 1929-35)

1971 - Lukacs's History and Class Consciousness (German: 1923)

1971 - Lukacs's The Theory of the Novel (German: 1920)

1971 - Sartre's 'The Burgos Trials' published in French and English

1971 - Orwell

1972 - Adorno and Horkheimer's Dialectic of Enlightenment published in English (German: 1944)

1972 - Barthes's Mythologies (French: 1957)

1973 - Adorno's Negative Dialectics (French: 1966)

1973 - Marx's Grundrisse (German: 1939)

1973 - The Country and The City

1974 - Television

1975 - Goldmann's Towards a Sociology of The Novel (French: 1963)

1975 - Timpanaro's On Materialism (Italian: 1970)

1976 - Sartre's Critique of Dialectical Reason vol 1 (French: 1960)

1976 - Timpanaro’s The Freudian Slip (Italian: 1974)

1976 - Keywords

1977 - Lacan's Ecrits (French: 1966)

1977 - Bahro's The Alternative in Eastern Europe (German: 1976)

1977 - Marxism and Literature

1978 - Lukacs's 'Realism in the Balance' (German: 1938)

1978 - Benjamin's The Origin of German Tragic Drama (German: 1928)

1978 - The Volunteers 
1979 - Politics and Letters

1979 - The Fight for Manod

1980 - Lukacs's Essays on Realism (German: 1971 but essays written in the thirties)

1980 - Problems in Materialism and Culture

1981 - Culture

1983 - Towards 2000

1984 - Bourdieu's Distinction: A Social Critique of the Judgement of Taste (French: 1979)

1985 - Loyalties

1988 - Williams's death

1988 - The Politics of Modernism

1989 - Resources of Hope

1989 - People of the Black Mountains vol. 1

1990 - People of the Black Mountains vol. 2

1991 - Sartre's Critique of Dialectical Reason vol. 2 (French: 1985)

As we have seen, Williams could read French and, although he could not read German, his academic situation will have kept him abreast of some European ideas which had yet to make the crossing. Nevertheless, there is good reason to believe that Williams encountered most of these texts first in English translation, and so this chronological view allows us to make some initial observations. As we shall see, there are numerous occasions on which Williams signals his enormous frustration that Britain has been impoverished for so long by the more egregious translation delays.

Even excluding the extraordinary lateness of some of Marx's texts in English, the general situation is one of severe cultural lag. In general, the earlier the original publication in German, French or Italian, the worse the delay; evidently, the cultural journey had shortened by the seventies (not least due to the efforts of NLR). Thus Lukacs's History and Class Consciousness takes forty-eight years to cross, Bahro's The Alternative in Eastern Europe just one. By the time of Williams's first tranche of publications in the early to mid-fifties (Reading and Criticism to Drama in Performance), he only really had access to Fromm, writing in English in the U.S., to Sartre's plays, one book by Lukacs, to Freud and some of Marx. By the publication of Culture and Society, we can add one further major FreudoMarxist text from the Frankfurt School in English (Marcuse's Eros and Civilisation), Sartre's Being and Nothingness (thirteen years after the French) and a truncated selection from 
Gramsci, The Modern Prince and other Writings. Saussure's Course appears in 1959, fortythree years late. Fromm, Freud, Marx and Sartre all make appearances in The Long Revolution (1961); the absence reference to Saussure, Lukacs and Gramsci is forgivable in a British context of general disinterest - Williams was making broad contact with what was available. Between The Long Revolution and the mid-to-late sixties period of Modern Tragedy (1966) and Drama from Ibsen to Brecht (1968), more work of Lukacs and Marcuse is made available, along with Brecht's theoretical pieces and Sartre's existentialist-Marxist 'pivot' text, Search for a Method. Again, Williams makes use of the material. Williams (1962 \& 1963) reviews the extant English texts from Lukacs ${ }^{42}$ and the Brecht essays inform Williams's analysis of his plays in Modern Tragedy; whether Sartre's Search for a Method did the same for the Sartre/Camus material is less clear. ${ }^{43}$ European theory is far from absent, then, in Williams's work as of 1968, but there is nothing comparable to the statement of affinity already to be found in Anderson's 'Socialism and Pseudo-Empiricism' (1966).

As Barnett (1976) rightly concluded, the real shift towards Europe comes in the period between the May Day Manifesto (1967) and Marxism and Literature (1977). Between 1969 and 1973, when The Country and the City (in Williams's own words a kind of Marxist 'break' (Williams, 1985a, p. 209)) appeared, major works by Levi-Strauss, Benjamin, Althusser, a more comprehensive Gramsci, Lukacs, Sartre, Adorno, Horkheimer, Barthes and even Marx (the Grundrisse) appear in English for the first time. Some of these, like Althusser's For Marx and Reading Capital, are translated relatively quickly, while others, especially Lukacs's History and Class Consciousness, Benjamin's work, Gramsci's Prison Notebooks and the earlier Frankfurt School material, were between twenty-five and fifty years overdue. Over the next four years to 1977 and Marxism and Literature, major works by Goldmann, Timpanaro and Lacan become available, plus Bahro's The Alternative and Sartre's late opus, the Critique of Dialectical Reason (vol. 1), which Williams enthusiastically reviews in The Guardian. Williams wrote a huge number of reviews of European writers in the sixties and seventies, primarily for The Guardian and New Society. Williams reviewed no fewer than forty-five texts by or about the major European thinkers listed above in his lifetime, at least twenty-five of these in a ten-year 'Europhile' window between 1967 and 1977. Williams's catalogue of reviews has rarely drawn much attention, despite it constituting an enormous body of critical engagement. This thesis draws heavily on

\footnotetext{
${ }^{42}$ For discussion see Chapter One, pp. 50-56.

${ }^{43}$ For discussion see Chapter Two, pp. 117-128.
} 
Williams's reviews of European writers, collected among Williams's papers in the Richard Burton Archives at Swansea University.

Of course, Williams's engagement with European thought was not confined to reviews. As we have seen, Williams was incorporating the insights of European thinkers into his work from at least TLR, with further engagements in Modern Tragedy and DFIB, but there is a sharp uptick in the late sixties, beginning with an essay on Marcuse for The Cambridge Review $^{44}$ (1969) and coinciding with Williams's lecturing on European theory at Cambridge. ${ }^{45}$ I offer here only a summary of Williams's discussions of European thinkers in his essays and books after 1968; we will return to many of these texts later. Appropriately enough, many of the relevant essays appear in NLR. The first was 'Literature and Sociology: In Memory of Lucien Goldmann' (1971), first given as a talk at Cambridge in the same year. Goldmann had died in 1970 and Lukacs, who features heavily in the piece, passed away just months after Williams's talk. In 1972, another talk of Williams's, given in Montreal, was transcribed for The Listener; 'Lucien Goldmann and Marxism's Alternative Tradition' (1972) is a crucial text for thinking through Williams's Europeanism, and plays a structural role in this thesis. ${ }^{46}$ It was followed a year later by a classic text of the period: 'Base and Superstructure in Marxist Cultural Theory' (1973), which established the basic parameters of Williams's Gramscian critique of both orthodox and structural Marxism. Williams would expand his analysis of hegemony in Marxism and Literature alongside discussions (of varying length and detail) of Althusser, Benjamin, Adorno, Brecht, Goldmann, Lukacs, Saussure, Bakhtin and Sartre. Rounding out the 'cultural materialist' NLR pieces of the seventies was 'Problems of Materialism' (1978), in effect an essay-length review and discursus on Timpanaro. Significant discussions of Lukacs, Brecht, Sartre, Freud and

\footnotetext{
${ }^{44}$ We get a sense of the importance of Marcuse for Williams in the following passage from the 1969 essay: 'For historical reasons, we have been separated, in Britain, from a critical and philosophical tradition which, when we re-encounter it in Marcuse or in Lukacs, is at once strange and fascinating: at once broader and more confident, more abstract, and yet more profoundly involved than our own. I felt the size of this gap, and yet the interest and pleasure of a possible bridge across it, in one of Marcuse's essays from the thirties, reprinted in this volume, on the "The Affirmative Character of Culture". The particular interest of the essay, for me, is that its analysis corresponded so closely with a central theme of Culture and Society, and that both were historical treatments of very much the same problem, which were yet continents or countries apart in method and in language. It was a marvellous moment of intellectual liberation to read across that gap into a mind which in all but its most central area of concern and value was so wholly other and strange' (1969, p. 367).

${ }^{45}$ In a notebook dated January $23^{\text {rd }} 1974$ and titled 'Theories of Culture', Williams's lecture notes expound on ideas of culture in European thought from $18 \mathrm{C}$ to the present. The names mentioned give a flavour of the kind of concerted engagement with European thought Williams was making: Volataire, Herder, Montesquieu, Vico, Rousseau, Marx, Engels, the Frankfurt School, Lukacs, Gramsci, Pareto, Mannheim, Weber, Durkheim, Comte, Jung \& Althusser.

${ }^{46}$ See pp. 37-39.
} 
psychoanalysis, Timpanaro, Saussure and Bahro can be found in Politics and Letters (1979) alongside briefer comments on Goldmann, Althusser, the Frankfurt School, Lacan and Bourdieu.

Following the period of his most concerted engagement with European Marxism, Williams wrote several essays assessing the state of literary and cultural theory in Britain and its possible futures. ${ }^{47}$ These texts, alongside Culture (1981) and a range of essays on modernism and the avant-garde, ${ }^{48}$ placed European theory centre-stage in Williams's transition away from traditional literary criticism and towards the broader practice of cultural materialism or the 'sociology of culture'. Williams had laid the foundations of cultural materialism in Marxism and Literature and the NLR essays of the seventies; in the eighties, particularly in Culture, he offered more programmatic interventions. Within what he considered the terms of a materialist-idealist synthesis, Williams (1981) argued for a discipline which would combine 'the anthropological and sociological senses of culture as a distinct "whole way of life", and the sense of culture as 'all the "signifying practices" - from language through the arts and philosophy to journalism, fashion and advertising' (p. 13) to produce an overarching sociological enterprise. Williams emphasised that such a project had only been made possible because of the interventions of European Marxist critics, among them Lukacs, Goldmann, Benjamin, Adorno and Marcuse, who had provided ways of studying the relations between 'forms' and social relations, and between material conditions, signifying practices and aspects of ideology and consciousness.

Williams examined the disorienting effect which some of these Marxist cultural theories, alongside structural linguistics, post-Althusserian structuralism ${ }^{49}$ and Russian formalism, were having on British literary studies in an NLR piece, 'Crisis in English Studies' (1985a). This was written in response to the 'MacCabe affair', in which marxisant cultural critic Colin MacCabe was denied a permanent lectureship at Cambridge by a Faculty Board unprepared to institutionalize European innovation. In a late parallel with the New Left Review furore, Williams sided with the prevailing theoretical winds and fought in MacCabe's corner. Recounting the recent history of theoretical innovations, Williams distances himself from psychoanalysis and structuralism, and affirms the potential of an as-yet unformed 'fully historical semiotics'. 'Cultural materialism', he contends, 'is the analysis of all forms of

\footnotetext{
${ }^{47}$ See (1985a), (2007a) \& (2007b).

${ }^{48}$ These essays are collected in Politics of Modernism: Against the New Conformists (1989).

${ }^{49}$ Williams notes, for example, the influence of Eagleton's Criticism and Ideology (1976) of Pierre Macherey (1985a, p. 207).
} 
signification, including quite centrally writing, within the actual means and conditions of their production' (p. 210). Since much Western Marxist cultural theory has been criticism, rather than sociology, Williams argues that 'most actual Marxist and structuralist tendencies have been ... compatible or even congruent in a broad sense with the orthodox paradigm' (p. 211), that is, the 'dominant literary paradigm' (p. 209) which emphasises the uniqueness of literature as a distinct symbolic practice. In Williams's estimation, much of his own work was carried out within this broad orthodoxy. His late work, however, is included among the three modern positions Williams now takes to be incompatible with 'Cambridge English': traditional Marxist base and superstructure analysis, among which Williams counts The Country and the City (1973), 'radical semiotics' (confusingly, Williams uses this term as a synonym for deconstruction ${ }^{50}$ ), and cultural materialism. Each of these, argues Williams, share an incompatibility with orthodox literary criticism in that they 'necessarily include the [literary] paradigm itself as a matter for analysis, rather than as a governing definition of the object of knowledge' (p. 211). They are, in other words, versions of a total theory of cultural production, reserving no special place for literature, or indeed for any other cultural practice. For Williams, of course, cultural materialism is the worthiest alternative to Cambridge orthodoxy. Traditional Marxism and deconstruction are the polarised extremes (one materialist, the other idealist) of total cultural analysis between which Williams will try to steer his sociology of culture.

A key influence on Williams's mature sociology of culture was Pierre Bourdieu. It appears to have been E. P. Thompson, intriguingly, who put Williams on the French sociologist's trail. On an undated postcard to Williams, presumably from the mid-seventies, Thompson writes:

Just back from a second colloque in Paris: something peculiar is happening there. A group of scholars of the left, younger than me but not very young, are trying to make

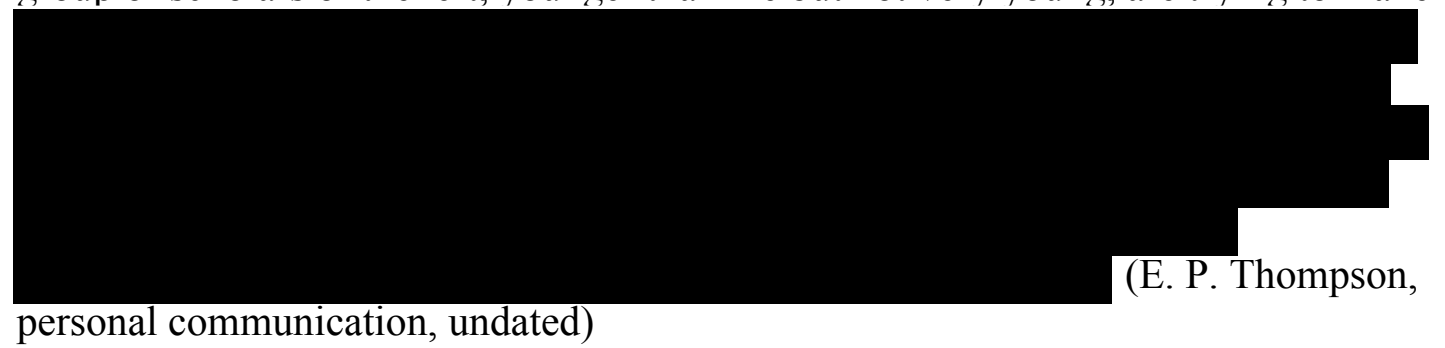

Williams would meet Bourdieu in France in 1976, giving a talk that December; later the same month, Bourdieu wrote to Williams in English:

\footnotetext{
${ }^{50}$ In 'The Uses of Cultural Theory' (2007b), Williams describes post-structuralist linguistics more broadly as 'a now increasingly false and misleading' distortion of Saussure (p. 171).
} 
I am most pleased with our meeting and hope that this may be the beginning of a

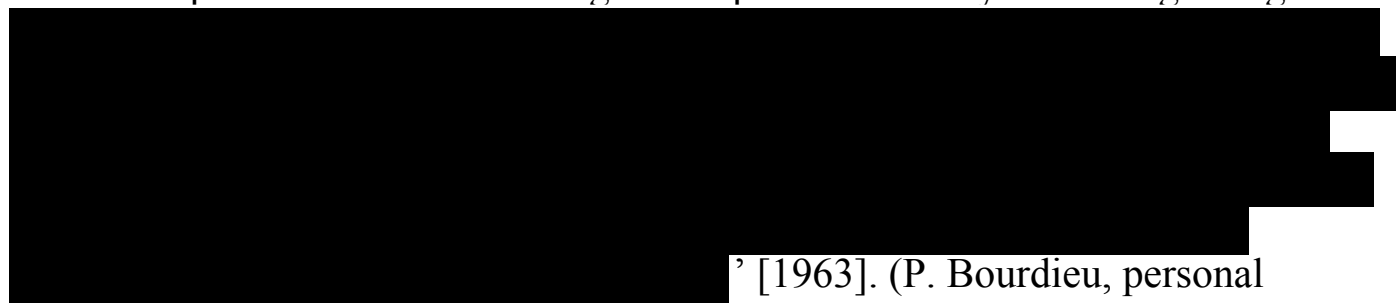

communication, December 22, 1976).

In the same letter, Bourdieu requests to publish a chapter from William's Television in his journal Actes de la recherché en sciences sociales. As in Ferrara's account, we find a sense of transnational, mutual affinity and influence, in particular here around the concept of the sociology of culture, and an aggrieved awareness of national insularity. Bourdieu would later express this in praise of Marxism and Literature: 'I read your book ... with interest and agree profoundly with you ... the fact is, I feel so isolated here that the extent of our agreement seems to me somewhat miraculous' (P. Bourdieu, personal correspondence, December 7, 1977). Williams's association with Bourdieu in the seventies proved so fruitful that, as the eighties began, Williams wrote (with Nicholas Garnham) 'Pierre Bourdieu and the Sociology of Culture: An Introduction' (1980), in which the authors argued that Bourdieu's work 'dialectically supercedes [sic]' (p. 210) three extant and opposing tendencies within cultural studies: culturalism, Althusserian structuralism/formalism and more recently, a resurgent political-economic Marxism emerging in response to Althusserian/Lacanian theoreticism. They viewed Bourdieu as grounding a materialist theory of symbolic power in class relations without dismissing either as merely secondary or affording either undue privilege. Such was Williams's goal, the task to which he set, at various points, the terms 'realism', 'totality', 'hegemony' and 'cultural materialism'. It is no exaggeration to say that Williams regarded Bourdieu's emphases as something like the future of cultural studies, and certainly the direction in which he would be taking his own work. The rather sad coda to Williams's association with Bourdieu is that in 1987, Bourdieu wrote to Williams to request his collaboration on a transnational journal of European letters that would try to bridge the divisions between Europe's national intellectual cultures. ${ }^{51}$ Williams would pass away the following year.

\footnotetext{
${ }^{51}$ Bourdieu's prospective journal was to have an innovative format: the first half of each issue would contain essays from scholars in the country of publication, while the latter half would comprise a common set of essays from across Europe in translation. To my knowledge, the journal never appeared.
} 
This thesis is structured as a series of detailed discussions of Williams's writings on the three European figures who, in my view, had the greatest overall influence on his thought: Lukacs, Sartre and Gramsci. Williams's engagement with these thinkers was more substantial than with any others (with the exception of Brecht - see p. 40), and speaks to the specific character of his Europeanism. It is far from coincidental that these three thinkers were also those with whom Anderson and Nairn aligned themselves in the mid-sixties. In 'Lucien Goldmann and Marxism's Alternative Tradition' (1972), Williams emphasised the significance of this same triumvirate:

Of the two men who died, Georg Lukacs was clearly the more widely significant figure. His History and Class-Consciousness, a collection of essays written in the early Twenties, is the most important single work of what can be seen - in part against the disavowal of its author - as the alternative tradition of Marxism. In the scale of its contemporary influence it is joined only by the Prison Notebooks, from the late Twenties, of Antonio Gramsci, and by the work of Sartre in the Fifties and Sixties. As we look at the range of this work, from fundamental philosophical problem to questions of strategy, tactics and political organisation, we can properly call it, over a very wide field, a tradition ... the most significant feature of this alternative Marxist tradition is its account of consciousness: a social analysis which seems to me radically different from what most people in Britain understand as Marxist. (1972, p. 375)

Williams does not go as far as Anderson in claiming allegiance to this tradition, but there can be little doubt that he regarded this body of work as the central instance of socialist thought moving beyond both mechanical materialism and ahistorical, liberal idealism: 'Consciousness is restored as a primary activity: that is the central result of this alternative Marxist tradition. But this consciousness is still social, and it is centred in history' (p. 375). Within the Marxist tradition, of course, these were the paradigmatic thinkers of the totality, whose work arose out of the confluence of Marxism with late-nineteenth and early-twentieth century forms of anti-positivist rationalism and, often enough, idealism. These figures were descendants of that older European generation H. Stuart Hughes had identified in his Consciousness and Society: The Reorientation of European Social Thought (1958), thinkers who were reacting not just against classical Marxism, but also against the positivist reaction to Marxism itself. As Marxists, Lukacs, Sartre and Gramsci restored a critical emphasis to European thought, but in a way that incorporated the lessons of their idealist forebears and opened out new possible futures for historical materialism. Anderson's theory that Williams was doing something similar with the idealist tradition of English literary criticism could only have been speculative in the mid-sixties; by the late seventies, it had been confirmed. In the following 
chapters I track the influence of Marxism's alternative tradition on Williams's development. I argue that what emerges from these interactions may be regarded, in the context of post-war British socialism, as a unique fusion of British and European intellectual traditions.

Much critical attention has rightly been placed on Williams's reception of Goldmann, a 'second generation' figure within the alternative tradition whose positions were undoubtedly closer to Williams's mature thought, and with whom he had a brief personal friendship. In Chapter One, however, I focus on Lukacs, with whose work Williams was familiar from an earlier stage and which he wrote on at greater length. Lukacs is the figure that binds Williams and Goldmann, providing the theoretical ground for their interactions. Critical attention has been less forthcoming on the influence of Lukacs on Williams, perhaps because much of Williams's engagement takes the form of reviews. I begin by outlining Williams's reception of Lukacs and addressing his early assessments in the sixties reviews. I then measure the impact of the long-awaited History and Class Consciousness and track Williams's subsequent development, in critical dialogue with Lukacs and Goldmann, of cultural materialism in the seventies. Finally, I interrogate Said's (1983) account of intellectual transmission and establish Williams's late perspective on Lukacs in the eighties reviews.

The near-total lack of engagement with Sartre's influence on Williams is, as I have said, an egregious aporia in the critical literature; I attempt to remedy this in Chapter Two, which is organised along more thematic lines. After outlining Williams's engagement with Sartre, I connect Williams's analyses of Sartre's plays to his broader sense of the structure of feeling of modern drama in the sixties and to his assessment of Brechtian theatre. I then assess Williams's relation to political and philosophical liberalism by means of comparison with Sartre on the crucial questions of human freedom and the political duty (or lack thereof) of the committed artist; Williams's 1976 review of Sartre's Critique and his later essays on aesthetics are key here. The final sections of the chapter argue for Sartre as a major influence on Williams's turn towards Welsh nationalism in the early seventies, reading side-by-side their views on the complex interaction of nation and class within a socialist and antiimperialist politics.

With Gramsci, no doubt due to the Italian Marxist's early death, Williams's engagement is predominantly with a concept, hegemony, rather than with a series of texts. But the links to Gramsci go much deeper, illuminating a shared cultural and political paradigm that bears significant investigation. Chapter Three completes a broad transition over the course of this 
thesis from questions of literary theory to questions of politics. My analysis here is more speculative and theoretical than in the previous chapters, and offers an original interpretation and development of Williams's Gramscianism. I read Williams's quasi-empiricist redeployment of hegemony as in essence a theory of reification, that is, of class domination buttressed by 'a sense of absolute because experienced reality' (Williams, 1983, p. 38). I then consider Williams's views on counter-hegemony and the role of culture in social revolution. I affirm Williams as a revolutionary socialist and present a theory of the long revolution as a form of what Gramsci called a 'war of position', drawing on Gramsci’s 'interregnum' scenario in The Prison Notebooks for theoretical support.

Williams wrote as much about Bertolt Brecht as he did about any of the figures of Marxism's alternative tradition. I will have occasion to refer to Brecht at numerous points and a full section in Chapter Two is devoted to Williams's readings of Brecht's major plays in Modern Tragedy and Drama from Ibsen to Brecht. I justify the omission of a comprehensive chapter on the German playwright on two grounds: first, that this thesis is primarily an account of the influence of European 'theorists' and philosophers, in particular those of the 'alternative tradition', on Williams's own theoretical and political positions. Brecht did, of course, produce theoretical work, but he was primarily a playwright, whereas Sartre can lay claim to being a prodigious philosopher in his own right, in addition to being a playwright and novelist. Secondly, because while some of Brecht's notions, in particular that of 'complex seeing', did influence Williams, Brecht cannot be regarded as a thinker of the totality in the same way as Lukacs, Sartre and Gramsci. A full, standalone discussion of Williams's engagement with Brecht's drama and thought, making full use of Williams's many reviews of Brecht and his critics, deserves to be written. Here I confine myself to the central influence on Williams of Marxism's 'alternative tradition'. 


\title{
Chapter One
}

\section{Williams and Lukacs: Realism, Class, Totality}

\author{
An Outline of Williams's Engagement with Lukacs
}

Williams closed his 1984 review of Lukacs's autobiography, Record of a Life (1984), with a note of intellectual exhaustion. Lukacs's legacy would go on being debated ...

... but in another sense that whole phase is ended, or ought to be ended: that movement of high intellectuals, with their own curriculum and preoccupations, towards the labour and democratic movements. Their memory can be honoured as a way of understanding and beginning to reverse the relationship, until the 'return to everyday life' is not a categorical conclusion but a hard and contested starting-point. (1984a, p. 15)

The word 'ought' in the above quotation asserts the superiority of something like the approach which Williams favoured and had slowly developed over the course of his life: the version of Marxist humanism which Williams finally named, in Marxism and Literature (1977), 'cultural materialism' (p. 5). Opposed to this is the quasi-involvement of sympathetic intellectuals who remain nevertheless largely detached from either the political realities of socialist struggle, or the lives 'as lived' of those they sought to represent in their emancipatory social theories. This, of course, was Anderson's (1976) critique of the Western Marxist tradition generally, that the bond between theory and practice had been broken, leaving only theory. It should be noted that this formulation, as Anderson conceded, applies least of all to Lukacs of all the central figures of Western Marxism. But Williams's point survives contact with Lukacs's biography, for it is a broader one: that 'everyday life ${ }^{, 52}$ is the only possible site of enquiry, the only possible seed-bed of socialist consciousness and struggle, available to even the most engaged intellectual. It was this passionate attachment to the fabric of people's personal experiences which set the meandering course of Williams's

\footnotetext{
${ }^{52}$ Williams abiding concern with 'everyday life', which informs every aspect of his work from the 'culture is ordinary' emphasis to the late work on hegemony, recommends a comparison with Henri Lefevbre, whose Critique of Everyday Life (three volumes, Fr. 1948, 1961 and 1981) was a significant influence on French antiStalinism.
} 
own engagement with Marxism and formed the background of his theoretical reservations about Lukacs.

Williams's reception of Lukacs's work was both long and difficult. Unable to read German, Williams was forced to read Lukacs as he was published in English. The extraordinary lag between the German and English editions of some key works was a constant frustration. The seminal History and Class Consciousness (English: 1971 - hereafter HCC), originally published in German in 1923, took forty-eight years to appear in English. Williams (1971) regarded the intellectual worth of $H C C$ as monumental, describing it in his review as 'one of the indispensable works of the twentieth century' (The Guardian, 1971, Feb 25, p. 8), and finding it 'remarkable that it has taken half a century to get it in English' (p. 8). Already in 1962, while reviewing the English edition of The Historical Novel (English: 1962 - hereafter $T H N$ ), itself twenty-five years overdue, Williams was noting the 'desperate need' (The Listener, 1962, March 8) for an English edition of HCC. British literary criticism, it seemed, was always lagging behind. In 1980, reviewing the English edition of Lukacs's Essays on Realism (English: 1980) nearly fifty years after they appeared in German, Williams is keen to point out the prefiguration of contemporary British debates around realism and modernism 'in the lively controversies between socialist writers, especially Russian and German, in the twenties and thirties' (New Society, 1980a, Nov 20, p. 381).

In keeping with William's tendency to equilibrate, the final judgment offered on Lukacs is balanced. Lukacs remained for him a thinker of the greatest importance and usefulness for contemporary thought, particularly in considering realism and the prospects for articulating diverse and heterodox versions of Marxist thought (the irony then being that Lukacs regarded himself as quintessentially orthodox, in the sense of 'true to Marx'). But in 1984, reviewing Lukacs's Record of a Life, there is severe disagreement: cultural materialism, says Williams, is a 'diametrically opposite answer to the questions which Lukacs and other Marxists have posed' (p. 15), particularly when it comes to the social character of art. For Williams, the lineage which Said traced in his 'Travelling Theory' (1983), from Lukacs through Lucien Goldmann to Williams himself, did not, in the end, express a 'meeting of minds' (p. 15); the differences in fundamental approach to Marxist criticism are simply too stark. And yet one of the crucial elements of Williams's discovery of Lukacs is the extent to which it is felt, particularly in its early stages, as symptomatic of discovering, late in the day, an intellectual horizon to which British literary and political debate must urgently catch up. 
The sheer material struggle involved in taking the measure of Lukacs at any point shadowed the struggle which Williams faced in coming to terms with the most resonant aspects of the intellectual inheritance of the 'contemporary Marxism' (1989r, p. 76) he eventually aligned himself with. Williams was not good at acknowledging intellectual influences and referenced theoretical work by other writers (even British ones) only sparingly; Lukacs, however, was one of his more constant references outside of the English-speaking world, the thinker to whom he most frequently referred (much more so, tellingly, than Marx himself). Williams's reception of Lukacs spans almost the length of his career, and so his own positions evolve in parallel with his encounters with Lukacs. The relationship between the development of Williams's work and his collisions with key Lukacsian texts and categories is the object of this chapter's investigations.

It is possible to group Williams's reception of Lukacs into three broad periods, the movement through which may be compared to the development of Williams's thought in general. These periods are a) the early sixties, in which the first few of Lukacs's books are made available in English, b) the early seventies, with the long-awaited publication of $H C C$ and some interesting theoretical engagements by Williams, and c) the late seventies through to the mideighties, when most of what is even now available in English by Lukacs had been published and Williams was at the height of his engagement with Marxism and its many internal debates. Chapter One of this thesis will describe these dual developments, of Williams's reception of Lukacs and the slow evolution of his own cultural materialist position, in some of their mutual interactions. The fact that Williams reviewed many of Lukacs's works in the years they were made available in English provides us with a fortunate scattering of signposts; at the same time, very many more works were made available over the course of Williams's career than he reviewed or commented upon. The result is that we can be very specific about when Williams's encountered certain texts, but must be entirely speculative about the rest, unfortunately the greater number.

Between the publication of Williams's first book, Reading and Criticism (1950) and The Long Revolution (1961), he would only have had access to one of Lukacs's books in English, Studies in European Realism (English: 1950, German: various, thirties - hereafter SIER) and we cannot be certain that Williams's read even this text until as late as 1962 (it is mentioned for the first time in his review of The Historical Novel). Williams therefore remained almost 
entirely disconnected from Lukacs's work until after the publication of The Long Revolution; as he says of the period of writing that text in 'Literature and Sociology' (1971), 'it seems to me extraordinary, looking back, that I did not then know the work of Lukacs or Goldmann, which would have been highly relevant to it, and especially as they were working within a more conscious tradition and in less radical an isolation' (2005f: 20). In 1962 The Historical Novel (German: 1937) was published in English, and The Meaning of Contemporary Realism (German: 1958) in 1963. Williams reviews both of these in the years of their English publication and so, by 1963, we can say with certainty that Williams had read The Historical Novel, The Meaning of Contemporary Realism and Studies in European Realism.

By Modern Tragedy (1966), then, Williams had come into contact with one book and one essay collection from Lukacs's literary-critical period in the thirties (THN (Russian: 1937) and SER (various essays dating from the late thirties)), and one later text from 1958 (MCR (German: 1958)). A number of essays by Lukacs had appeared in English by 1963, primarily of a political nature, but we cannot know whether Williams encountered these. From 1963 until 1971, when History and Class Consciousness (German: 1923 - hereafter HCC) was finally published in English, there is no hard evidence that Williams read any further texts written by Lukacs, with the exception of Solzhenitsyn (German: 1969), which appeared in English in 1970, and which Williams reviewed with HCC in 1971. English editions of Essays on Thomas Mann (1964) and Goethe and his Age (1968) appear during this period, as do Lenin: A Study in the Unity of his Thought and Writer and Critic and Other Essays in 1970; Williams may or may not have read these texts.

Between 1971 and the publication of Marxism and Literature (1977), which includes the period of The Country and the City (1973), a large number of essays and books by Lukacs are made available in English. Lukacs's pre-Marxist The Theory of the Novel appears in 1971 alongside HCC. Tactics and Ethics (1971), Marxism and Human Liberation (1973), Conversations with Lukacs (1974), Soul and Form (1974) and The Young Hegel (1975) all appear in the intervening years; given the significance of Lukacs to Williams as a writer, it seems likely that he would have read at least some of this output, but we cannot say for sure. In the book list to Marxism and Literature, Williams lists The Theory of the Novel (German: 1920, English: 1971). 
While Williams does not explicitly reference The Specificity of the Aesthetic (German date; it remains unpublished in English as of the time of writing) until Culture (1981), he does attribute the phrase 'the specificity of the aesthetic' (2009 [1977], p. 151) to Lukacs and discusses some of the concepts derived from that work in Marxism and Literature. It remains unclear whether Williams encounters the text in its primary form (unlikely, given that Williams did not read German) or via secondary material. In Culture, Williams references a 1969 Frankfurt edition of a text titled Die Eigenart des Ästhetischen. This probably refers to a later edition of Lukacs‘s 1963 work Ästhetik. Teil I. Die Eigenart des Ästhetischen (Aesthetic, Part 1: The Peculiarity of the Aesthetic), the first part of his planned Aesthetics, but may also refer to a 1969 text, Probleme der Ästhetik, the third chapter of which is titled Über die Besonderheit als Kategorie der Ästhetik (On Particularity as a Category of the Aesthetic). The balance of evidence suggests that Williams encountered the first part of Lukacs's Aesthetics via secondary material in English, probably a PhD thesis by John Fekete (1972) included in the Marxism and Literature book list (Williams refers to Fekete's comments on the difficulty of translating the German Eigenart into English while discussing Lukacs's text).

We can be certain that Williams read the essay 'Realism in the Balance' (German: 1938) in 1978 as part of reviewing NLR's Aesthetics and Politics collection, and that he read Essays on Realism (German: 1971, essays dating from thirties and forties) in 1980, again reviewing this in the year of its English publication. In the four years between Marxism and Literature and Culture, Williams would have had the opportunity to read all three parts of Lukacs's Ontology, the first two of which were published in English in 1978, the third in 1980, and The Destruction of Reason (1980), although, once again, there is no hard evidence to suggest that he did. In addition to the texts by Lukacs himself, in 1978 Williams reviews Goldmann's Lukacs and Hiedegger: Towards a New Philosophy (French: 1973, English: 1977) and in 1980 Michael Lowy's Georg Lukacs: From Romanticism to Bolshevism (1979). In 1984, Williams reviewed Lukacs's Record of a Life: An Autobiography (1984), also mentioning the early essay 'On Poverty of Spirit' (German: 1912) for the first time, although he may have read the latter in English from 1972 onwards. In the same review Williams comments on two further texts about Lukacs by critics: Agnes Heller's Lukacs Revalued (1983) and Lee Congdon's The Young Lukacs (1983). In summary, we know that Williams read or commented on the following texts by or about Lukacs (listed in chronological order of mention by Williams, with original and English dates of publication): 
1962: The Historical Novel (German: 1937, English: 1962) and Studies in European Realism (various original chapter publication dates in 1930s, English: 1950)

1963: The Meaning of Contemporary Realism (German: 1958, English: 1963)

1971: History and Class Consciousness (German: 1923, English: 1971) and Solzhenitsyn (German: 1959, English: 1970)

1977: The Theory of the Novel (German, 1920, English: 1971)

1978: 'Realism in the Balance' (German: 1938, English: 1978), Goldmann's Lukacs and Heidegger: Towards a New Philosophy (French: 1973, English, 1977)

1980: Essays on Realism (German: 1971 (essays written throughout 1930’s), English: 1980) and Lowy's Georg Lukacs: From Romanticism to Bolshevism (1979)

1981: Ästhetik. Teil I. Die Eigenart des Ästhetischen (German: 1963)

1984: Record of a Life: An Autobiography (1984), 'On Poverty of Spirit' (German: 1912, English: 1972), Heller's Lukacs Revalued (1983) and Congdon's The Young Lukacs (1983)

First, we should note the clear periodization: first the early sixties, then the early seventies with the crucial publication of $H C C$, then the period from Marxism and Literature on. Between each period lie gaps of several years. The period of reception, given that Lukacs was deceased with a 'complete' body of work by 1971, is very large; thirty-two years separate Williams's first and last encounters with Lukacs's work. Six years is the shortest gap between German publication and Williams's encounter with it (The Meaning of Contemporary Realism, first published in 1958), but for the majority of texts the span is much larger. Williams and Lukacs were born thirty-six years apart, but for nearly three decades they were contemporary writers; Lukacs was writing some of his most important works while Williams was mid-career. The villains here are not generational but geographical/cultural: the caprice of Lukacs's general reception in the English-speaking world and the exigencies of his translation. Nearly five decades separate the original publication of $H C C$ and the point when Williams, and indeed any other non-German-speaking British observers, could encounter it 'in the flesh'. HCC is Lukacs most significant and influential text, regarded by Williams, as we have said, as indispensable, and so the discovery of this fundamental work must have been both disorienting and revelatory. 
Another point of interest emerges from setting the real chronology of Lukacs's writing against the order in which Williams encounters them. Of the first three books which Williams reads, THN and SER are from the late thirties and MCR from 1958. The next major work encountered, $H C C$, dates from 1923, and so by 1971 Williams has read work from three quite different phases of Lukacs's life, in a muddled order, with the earliest read eight years later than the rest. This non-linearity continues: in 1977, Williams was encountering (in some form) the Aesthetic of 1953, followed shortly thereafter by a series of essays, from 'Realism in the Balance' to those of Essays in Realism, written throughout the thirties. With the review of Lukacs's autobiography in 1984, there is finally some chronological appropriateness. Generally, though, taking only those texts about which we have substantial knowledge of Williams's reception, the order in which the texts were read bears no relation to the order of their publication. This is not unusual in itself; when addressing the accumulated output of a writer whose work is finished, any order may serve the needs of the reader. But the point here is that Williams never had access to everything Lukacs wrote (non-German readers are still far from that today) and was not performing any kind of selection. He was forced to read Lukacs in a fragmentary and arbitrary order, without the concrete resources to place each text into its proper relation to the larger oeuvre. And, of course, Lukacs was writing right up until his death, coinciding with the English publication of $H C C$, in 1971.

The progression of Williams's fragmentary reception of Lukacs corresponds to the intensification of his theoretical engagement with Marxism, culminating in Marxism and Literature, the detailed discussions in Politics and Letters and the more explicitly sociological Culture (1981). Some caveats are necessary here. The development of Williams's Marxism was a process that was happening in a variety of ways and through the prism of a variety of concerns both cultural and political. It may be argued that Williams's reception of Lukacs occurred too sparsely, and at intervals too great to have had a truly significant effect on this development, but there can be no doubt that Lukacs, as Williams's most constant Marxist reference, was a central intellectual influence. The apparently parallel lines of Williams's reception of Lukacs and his own intellectual development were, as I argue below, closely intertwined.

Let us orient ourselves by briefly establishing Williams's late view. This can be introduced by referring to his own typology, in the Record of a Life review (1984a), of the dominant 
available viewpoints on Lukacs throughout the period of his widest British reception. The three dominant characterizations of Lukacs, says Williams, were as 'a more tolerable and less dogmatic than average Marxist literary critic' (p. 14), 'an outdated anti-modernist, antiBrechtian Stalinist' (p. 14), or as advocate of 'a humanist Marxism infected with strains of romantic anti-capitalism' (p. 14). The mutual exclusivity and tendency to polemic of these positions is clear. Williams himself cannot accept any of these positions as finally sustainable. Indeed, his comments on Lukacs throughout the years express all of the above positions in different combinations, refusing to settle on any one as definitive. By 1979 and Politics and Letters, which contains some of the deepest and most sustained explorations of many of Williams's major theoretical concerns, Williams has come to a fairly settled view of Lukacs; appreciative, but fully aware of some core theoretical differences.

In $19^{\text {th }}$ century literature and drama, broadly, Williams (2015 [1979]) feels that he and Lukacs 'would have argued in the same terms, but ... arrived at different conclusions' ( $\mathrm{p}$. 349). 'When, however, we come to the $20^{\text {th }}$ century,' says Williams, 'there is a radical divergence' (p. 349). The crux of problem, and what Williams interprets as explaining the disjunction between their positions across the two literary periods, is that 'Lukacs ... did have - much more strongly than I ever had; for this was the main reason for my distance from Marxist literary criticism for so long - the notion of a pre-existent social reality with which the literary model can be compared' (p. 349). This notion of a 'pre-existent' social reality, which in its broadest sense is common to almost all versions of the Marxist position, is the primary point of tension between Williams and Lukacs, and indeed between Williams and Marxism itself. It is, for him, 'where for a generation a certain mainstream of Marxism stuck' (p. 349), and constituted a 'major barrier when [Lukacs] came to consider the modernists' (p. 349). But it is crucial to note that Williams is not, with these comments, subscribing to an anti-realist position. He is not critiquing Lukacs's faith in an objective, material reality, but in a known social reality, transparent in its real complexity, to which literature can straightforwardly be related or compared. The result of Lukacs's preoccupation with a 'pre-existent' social reality, says Williams, is the assumption of a 'social reality to which that kind of [modernist] fiction corresponded ... which it described as decadence' (pp. 349-350). Williams maintained this aversion to both the notion of a 'pre-existent' social reality and the notion of 'decadence' throughout his life and work. 
Elaborating further on the dialectic of his convergence with and divergence from Lukacs, Williams (2015 [1979]) states:

So my accounts and those of Lukacs could be very similar for a type of literature in which the question - how does this fiction compare with otherwise observable (a phrase one can settle upon rather than pre-existent) social reality? - seems unproblematic. The realist novel of the $19^{\text {th }}$ century does not make it essential to clarify the differences between the otherwise observable and the pre-existent. They can appear virtually identical. But once you move to $20^{\text {th }}$ century fiction, the substantial theoretical divergence between them becomes critical. (2015 [1979], p. 350)

What is the theoretical divergence here and what work is the phrase 'otherwise observable' doing? Williams is concerned to refute two notions here; firstly, that we can speak of an irrefutable, theoretically known social reality, existing independently of culture and consciousness, and secondly that such a reality mechanically determines the shape of the fiction produced within it. The distinction between a 'pre-existent' and an 'otherwise observable' social reality, then, is that the former refers to a theoretical construct while the latter simply refers to the world external to the text, to which it bears a relation, but not one knowable in advance based on the theoretical construction. In fiction, such as the $19^{\text {th }}$ century realist novel, which actively attempts to depict 'otherwise observable' reality, the question of whether the depiction accords with a separate, theoretically determined version of reality is secondary; we can be relatively sure that the fiction in question is arising out of social reality and reflecting, at the very least, the way social reality appears (empirical realism). In $20^{\text {th }}$ century modernism, however, 'otherwise observable' social reality i.e. the world outside of the text which is available to perception, ceases to impress itself onto the fiction in the same way. The rise of modernist art confounds the previously existing relation and, for Lukacs, that means we must turn to an underlying or 'pre-existent' social reality, the reality uncovered by theory, to account for the lost purchase of art on its object. Bourgeois artists, argues Lukacs, in their late- $19^{\text {th }}$ and early- $20^{\text {th }}$ century 'decadence', lost ideological purchase on the social order over which their class continued to exert domination.

While Williams can agree that there is a 'breakdown' of the most obvious elements of the realist correspondence, he cannot take the further, Lukacsian step of claiming that this represents a period of 'decadence' in the ideological life-cycle of the bourgeoisie. Williams is happy to state that there has been a shift in the relation of art to 'otherwise observable' (nonliterary) reality and, as his own work on modernism demonstrates, is also concerned to assert 
a link between this shift and parallel shifts in other spheres of material production; what he will not concede is the existence of a theoretically transparent, class-tethered social reality to which this shift uniformly refers. It is a matter of some subtlety whether or not Williams's characterization of Lukacs, very loosely sketched above, is accurate; I will discuss this below. Williams's late position nevertheless provides us with a yardstick by which to measure the development of his responses over time, and to detect the relative shifts in his own position. We may now 'begin at the beginning', with Williams's reviews of the sixties.

\section{Williams and Lukacs in the Sixties}

In the sixties, Williams publishes two reviews, of The Historical Novel (1962) and The Meaning of Contemporary Realism (1963) in The Listener, and briefly discusses Lukacs's treatment of the tragic hero in Modern Tragedy (1966). Williams (1962) prefers THN to SER (we are not told exactly why), and declares that 'Lukacs has probably written one of the permanent classics of criticism ...' (p. 437). The tone is one of cautious high praise, the caution more pronounced by the close of the review: '... but at that level we need the caution of discipline. We shall only know, we shall only genuinely understand, after absolute and prolonged attention' (p. 437). There are two 'unknowns' here: whether or not THN will indeed find its place in the pantheon of modern critical classics, and whether or not what currently passes for understanding will stand the test of time. Part of the problem is the difficulty of the work, another the confused understandings current in Britain of the Marxist tradition: 'It is the work of a very original mind at a high theoretical level, and to approach it in the ready-made English context - through scraps of its author's life against a background of clichés about Marxism - seems inadequate if not insulting' (p. 436). Williams does not elaborate on the clichés, but we can assume them to be both political and philosophical: the equivalence of Marxism with Stalinism, and the assumption that Marxism can only reduce culture to something else, to non-culture. Notice that Williams is not absolving Lukacs of this charge, but rather claiming that it will be leveled in Britain regardless of its justice.

While considering THN a 'permanent classic of criticism', Williams nevertheless finds the overall argument 'not easy to accept as stated' (1962, p. 437). The idea that there is an essential truth buried within Lukacs's arguments which is not fully registered or expressed, is characteristic of Williams's reception of Lukacs's work. Stating his views only briefly in this review, Williams finds Lukacs weak on 'the nature of $18^{\text {th }}$ century realism' (p. 437) and on 'the Romantic response to the past' (p. 437), but strong on drama, to which 'he devotes his 
most brilliant chapter, which, if we attend to the preface, is really the core of the book' (p. 437). We should read this last statement alongside Williams's characterization of Lukacs's dramatic criticism in Modern Tragedy four years later. There Williams (1966) argues that, in his views on tragedy, 'Lukacs especially is a post-Hegelian rather than a Marxist critic' (p. 35). He reproduces some quotations from $T H N$ in support of this: '[the tragic hero is] the world-historical individual ... whose own particular purposes contain the substantial, which is the will of the world-spirit', and '[is the figure whose] personal passions centre upon the content of the collision' (p. 35). Lukacs's position, Williams goes on, 'is in fact doubtfully Marxist' (p. 35), elaborating: 'The identification of the 'world-historical individual' with the 'tragic hero' ... shifts attention from the objective conflict, which is present in the whole action, to the single and heroic personality, whom it does not seem necessary to regard as tragic if he in fact embodies "the will of the world-spirit" or of history' (p. 35).

How just is Williams's claim here? In $T H N$, Lukacs is concerned with the ability of drama to portray the historical totality, rather than with its capacity to generate a tragic charge; in order to perform the former function, he argues, protagonists must be those 'who in the selfcontainment of their personalities, can yet bear and reveal the fullness of the world' (Lukacs, 1983c, 119). Lukacs concedes the debt owed to Hegel's 'world-historical individual' in this formulation, but insists upon a strict Marxist translation and demarcation: 'One has only to translate the whole mysticism of the "spirit" into materialist, historical reality and to conceive as directly as possible this coincidence between the personality of the hero and the historical essence of the collision' (p. 119). Williams's (1966) claim that this is not a Marxist position is based upon what at first appears as a paradoxical critique: that Lukacs is annihilating both the objective ('shifts attention from the objective conflict') and the subjective factors (the tragic hero is deprived of his tragic character through his absorption into the world-spirit of history) of the tragic situation. It is then interesting to contrast the centrality of Williams's critique of orthodox Marxism (a critique of the strict separation of base and superstructure) with what appears here to be a critique of the conflation of the objective and the subjective. Clearly, what Williams has in mind as a properly total or realist view will neither separate out nor fuse subjective and objective factors, but rather set them into a dialectical relation of mutual constitution.

It is important not to regard Williams's characterization of Lukacs as a post-Hegelian as a criticism; such divergences from what Williams regards as Marxist orthodoxy (Lukacs's own 
insistence on orthodoxy notwithstanding) are, for him, essential to reclaiming a post-Stalinist tradition. In the 1971 essay 'Literature and Sociology', Williams puts the point as follows:

The fact that I learned simultaneously that [Lukacs and Goldmann's work] had been denounced as heretical, that it was a return to left-Hegelianism, did not, I am afraid, detain me. If you're not in a church you're not worried about heresies; it is only (but it is often) the most routinized Marxism, or the most idealist revolutionism, which projects that kind of authoritative, believing formation. The only serious criterion was actual theory and practice. (2005f, p. 20)

About this particular passage Eagleton (1976) remarked, 'One can almost see the approving marginal tick of the relieved liberal reader' (pp. 3-33). From the point of view of theoretical rigour and attention, Eagleton is surely right to suggest that 'If Williams is not in fact interested in the theoretical task of assessing Goldmann's [and, by association, Lukacs's] place within the Marxist tradition, then he ought to be' (pp. 3-33). But then, the evidence is not uniformly in Eagleton's favour; as we have seen, Williams described Lukacs as in some respects a post-Hegelian as early as 1966. Eagleton's political criticism, grounded in a firmly structuralist understanding of Marxism, has more bite. Isn't Williams's refusal to condemn the idealist elements in Lukacs the sign of an insufficient Marxism? At this stage, of course, Williams's mature Marxism is still in development, and will in any case be inimical to the young Eagleton's Althusserianism.

Despite some reservations, positive appreciation of Lukacs is the theme of Williams's engagements in the sixties. The 1963 review of $M C R$ (German: 1958) is particularly responsive, both to the text itself and to Lukacs as a thinker. Alongside commentary on the literary-critical material of the text, it also contains praise for Lukacs as a political thinker. Williams (1963) discusses the 1957 preface to the book, begun before and finished after the Hungarian Revolution of 1956: 'Lukacs, as a Marxist, had diagnosed and analysed this crisis before its public eruption, and it is extraordinarily impressive to see the way in which he goes on developing his central ideas after the bitterness of those months' (1963, Feb 28). The issue of Soviet authoritarianism found a literary parallel in the enforcement of 'socialist realism' upon revolutionary Marxist writers; Lukacs mounts a sturdy attack on the Stalinist elements in socialist realism, and in particular its tendency towards 'revolutionary romanticism', in $M C R$, which Williams praises in his review.

In terms of the critical substance of $M C R$, Williams (1963) singles out Lukacs's first chapter, 'The Ideology of Modernism', as particularly fruitful. 'I have not seen', says Williams, 'a 
better correlation of the style and the structure of the modern novel with its underlying assumptions about man' (1963, Feb 28), and furthermore suggests that, 'The analysis of "modernism" is the clearest Marxist criticism yet written of the movement we associate with Joyce, Eliot and Proust' (Feb 28). The 'underlying assumptions' are of man's 'natural solitariness' (Feb 28) and 'the conviction of an essentially static human condition' (Feb 28), or what Lukacs might have termed alienation and reification respectively. While Williams is supportive of Lukacs's critique of modernist assumptions, he is careful to distinguish this from 'the simple abuse of "decadence" (Feb 28) in THN (Russian: 1937). Indeed, Lukacs avoids the language of decadence in the fifties; the overriding keyword here becomes the 'disintegration' of man, society, meaning and even time in modernist literature. What Williams sees as an improvement in analytical subtlety, however, may be better viewed as a change in category to suit a new artistic object; the Lukacs of 'decadence' was concerned with what he saw as the deterioration of bourgeois critical realism through the $19^{\text {th }}$ century, whereas by the fifties he is concerned with the contemporary co-existence of the positive (adaptive realists like Mann, Roland and Gorky) with the negative/nihilistic (the anti-realist modernism of Joyce and Kafka).

What Williams detects, in Lukacs's later critique of modernism, is the shift of focus away from rigid class analysis to a critique which encompasses both class-rooted and other forms of experience, especially the overriding experience of the Second World War. For the Lukacs of $M C R$, the two great trends in bourgeois literature (modern realist and modernist) are still bourgeois, but they embody something of the exceptionality of the times and the contradictory class-formations present in phenomena such as the anti-Fascist and Peace movements. These new formations brought together radically antagonistic class and ideological elements. So heterogeneous were these elements, says Lukacs (1979), that 'The common ideological factor is thus, in Hegel's phrase, "an identity of identity and nonidentity"' (p. 15), that is, a common identity forged in and despite an interlocking network of similarities and differences. Lukacs states that 'it is no exaggeration to say that this new principle determining human allegiances' is now the 'starting-point' (p. 15) of his investigations. ${ }^{53}$ Already in 1963 , Williams is appreciative of this new focus on experiential plurality in Lukacs's work, but also of Lukacs's normative critique of the modernist

\footnotetext{
${ }^{53}$ It is worth noting the compatibility between this conceptualization and two others which will become important for Williams: Gramsci's hegemony (see Chapter Three for discussion) and Sartre's (1971) notion, also a Hegelian borrowing, of 'a true universalism through the common operation of all particularisms' (see Chapter Two, pp. 70-74 for discussion).
} 
'structure of feeling'. While Williams would not have concurred with Lukacs that modernism is 'the negation of art' (Lukacs, 1979, p. 46), he is alive to those elements of the Lukacsian critique which notice the potentially debilitating experiential focus on angst and nihilism in modernist writing. This is the focus of the second part of $M C R$, where Lukacs claims that 'between Franz Kafka and Thomas Mann, the contemporary bourgeois writer will have to choose' (p. 80). There is a passage at the mid-point of this essay with a certain Williamsesque cadence to it:

... acceptance or rejection of angst? Ought angst to be taken as an absolute, or ought it to be overcome? Should it be considered one reaction among others, or should it become the determinant of the condition humaine? These are not primarily, of course, literary questions; they relate to a man's behavior and experience of life. The crucial question is whether a man escapes from the life of his time into a realm of abstraction - it is then that angst is engendered in human consciousness - or confront modern life determined to fight its evils and support what is good in it. $(1979$, p. 80)

For Lukacs, the distinction between submission to the social order and its ethical (personal, moral and aesthetic) transcendence is, in literary terms, the distinction between historically total, realist portrayal, and the fragmented and subjective retreat into abstraction he associates with modernism. The artist has a 'duty' to observe the realist engagement with 'modern life' and to eschew the modernist indulgence in experiential angst (to choose Mann over Kafka). Williams's conception of 'duty' in art is very different to Lukacs's, but it still contains the crucial element of 'going beyond' what is given as social experience. For Williams, as he puts it in 'Art: Freedom and Duty' (1989b) the moment of ethical decision comes at the point at which the artist hesitates to continue mimicking the received speech, the 'familiar patterns which appear to make sense of a kind' (p. 94) (for example, modernist angst), towards which the subject as 'subject to' is pressured to gravitate: 'In much important writing it is the hesitation at that point, when the words can come all too easily - when the words are, so to say, ready-made - it is that hesitation which is the crucial condition ... something new is happening in the language itself' (p. 94). Both Williams and Lukacs, then, share a sense that artistic fidelity is about resisting dominant modes of experience and representation; this accounts for the Williams-esque character of the above passage. But whereas, for Lukacs, modernism errs when it ignores real life i.e. life outside of the dominant angst of 'inner' experience, for Williams, the failure of some modernist writers is that they ignore subaltern sectors of modern experience itself, the emergent experiences which exist below the surface of the modernist structure of feeling. 
Another way of putting the above is that the Lukacsian literary-critical discourse takes the most subjectivist modernist art at its word; it believes that the experience proper to modern life is angst, and then castigates the art that expresses this for doing so. Politically unhelpful art, on this model, is art which expresses politically unhelpful experiences, and if the only experiences available are politically unhelpful (angst, despair, nihilism etc.), then all art which focusses on experience will tend towards reaction. For the Williams of the sixties, however, art is only ever about the communication of experience, and so the Lukacsian model of evaluation cannot hold. In The Long Revolution (2013 [1961]), Williams describes art as the 'organization of experience' (p. 50) and progressive art as that which 'succeeds in describing and communicating new experience' (p. 51). The progressive nature of art, then, is not about its correspondence with progressive affects or representations, but in its facilitation of what Williams would eventually call the 'emergent' in social experience and culture, new and oppositional elements that resist the values and meanings of the dominant social order. Progressive art occurs when the artist succeeds in communicating some element, in his own experience, of an experience which exists socially but is as yet unrepresented. Thus the 'truth' to which Williams's positive ethical choice relates is not the truth which Lukacs would advocate in the choice of Mann over Kafka, the truth of the historically total portrayal; it is rather fidelity to an emergent social experience and commitment to finding the means of communication adequate to transmitting it.

Lukacs's conception of the ethical duty of the artist is essentially epistemological: the artist must understand, not merely express in an immanent way, social reality. Williams's focus on experience is very different from this, and yet in his review of $M C R$ (1963) Williams does appear to acknowledge that there is something progressive in Mann's 'struggle to comprehend' (1963, Feb 28) the social causes of angst and nihilism that is not present in, say, Kafka's expression of a certain dominant structure of feeling. As I argued in the introduction to this thesis and focus on in Chapter Two, Williams becomes less and less able to equate access to experience (in which the artist is especially skilled) to access to reality as his career progresses; the empiricist emphases of The Long Revolution give increasing ground to the need for abstract cognition in the seventies. Thus, while Williams cannot, as of his early sixties reviews, accept Lukacs's assertion that 'socialist' art must apprehend the real bases of social reality to avoid being reactionary, Lukacs's firm insistence upon the artist accounting for reality stays with Williams and significantly affects the trajectory of his thought. Later, Williams will combine the Lukacsian realist emphasis with what is already, in the sixties, a 
version of the Gramscian emphasis on emergent meanings and values, the necessity of discovering and building a socialist hegemony.

\section{Finally, History and Class Consciousness}

By the early seventies, Williams is visibly more comfortable with Marxist categories, and more willing to make specific theoretical pronouncements. The deaths of Goldmann and Lukacs seem to draw a line under an era of Marxist theory, and to inaugurate a new openness of possibility. ${ }^{54}$ Williams used his review of the long-awaited English edition of History and Class Consciousness, as well as the pieces 'Literature and Sociology' (1971) and 'Lucien Goldmann and Marxism's Alternative Tradition' (1972) as opportunities for retrospective, considering both his own work and the Marxist tradition in general from an early vantage on the new decade. These texts contain some of William's first and clearest engagements with Lukacs's conceptions of class consciousness and totality and, continuing the line of theoretical descent from The Long Revolution, prepare the ground for the explicit critique of base and superstructure outlined in the 1973 essay 'Base and Superstructure in Marxist Cultural Theory' and developed in Marxism and Literature (1977).

A good part of Williams's (1971) review is dedicated to the problem of receiving Lukacs in English and in the sclerotic context of Anglo-Saxon social theory. 'It is remarkable that it has taken half a century to get History and Class Consciousness into English' (The Guardian, 1971, Feb 25, p. 8), says Williams, 'For, whatever we finally think about its particular argument, it is one of the indispensable works of the twentieth century' (p. 8). The 'first quarter-century of neglect' (p. 8), as Williams describes it, was due to the fact that $H C C$ was described by Marxist orthodoxy as "a return to "idealism"; a Hegelian distortion of Marx and Lenin' (p. 8). In concert with this doctrinal suppression, it was at the same time 'part of a continuing Marxist argument which the equally orthodox social theory of the Anglo-Saxon world was neglecting' (p. 8). The double-headed threat which Williams's analysis depicts gives the measure of the challenge towards which Williams's own work was directed: to produce a social and cultural theory which would take the best insights from both the BritishAmerican and European traditions while avoiding both the idealism of either Angloliberalism or orthodox Marxism. The rigid binary between the two positions erected by

\footnotetext{
${ }^{54}$ These were personal, as well as intellectual events for Williams, who had maintained a friendship with Goldmann. He writes in 'LGM' (1972): 'I cannot easily explain my sense of loss at these two deaths' (p. 375).
} 
combatants on either side had been, for Williams, an absolute impediment. In the review, Williams expresses this in relation to his own work:

It is some indication of our slowness in recovering from the limitations then imposed that a further quarter-century has gone by without ordinary English access to a work which bears very closely on many of the most urgent themes we have been considering. I can only speak for myself, but I know that working in a wholly different intellectual tradition, I have been preoccupied by just the issues which Lukacs had so powerfully considered. (The Guardian, 1971, Feb 25, p. 8)

In this quotation is visible the bald fact that Williams did not, up until this period, consider himself as working within the Marxist tradition. Nor does he state explicitly in his review, or in the essays, that he is now working in that tradition (it was not until Marxism and Literature that the Marxist character of cultural materialism was explicitly affirmed). The reader, however, will be forgiven for thinking that these texts are written by a Marxist, since what comes through most clearly is Williams's conviction that the Marxist tradition must be recovered, explored, and renewed as a matter of urgency. Whether as a seed from which other theoretical contributions have sprung (those of 'Marcuse and Goldmann among others' (p. 8)) or as a major theoretician in his own right, Williams regards Lukacs as central to this project. 'In its movement beyond the abstract opposition of "idealism" and "materialism,", says Williams of $H C C$, 'and in its emphasis on consciousness as an active historical process rather than a set of "reflections" or "ideas," it represents a major position with which everyone who thinks about culture and society ought now to be familiar and concerned' (p. 8). For Williams, Lukacs is the deeply productive foundation upon which a more responsive and less abstract Marxism may be built in the seventies.

The false oppositions which Williams praises Lukacs for dismantling in the above quotation are, for him, aspects of the more general false opposition of base and superstructure. Williams tackles this in greater detail in the essays, but in the review of $H C C$ he proceeds with a different emphasis, suggesting that 'we can learn most about what Lukacs has to say about working-class consciousness and about bureaucracy' (The Guardian, 1971, Feb 25, p. 8). Williams points to the essays 'Class Consciousness' and 'Reification and the Consciousness of the Proletariat' as insightful texts for the 'linked issues of bureaucracy and working-class consciousness' (p. 8), which, he argues, 'ought ... to be at the centre of our thinking about both capitalist and socialist societies of our own day' (p. 8). Williams is in full agreement with Lukacs's description of bureaucracy as 'a form of organized activity - its 
own and the other human activities it controls - which is in a deep sense passive and static: a mode of adjustment to a world which it believes it controls but by which, finally, it is controlled' (p. 8). Lukacs of course, is primarily concerned with capitalist bureaucracy, but Williams insists that 'Communist bureaucracy is in the end the more serious problem, for it is more directly linked with the issue of working-class consciousness' (p. 8).

For Williams, then, what Lukacs has to say about class consciousness contains material which may be repurposed for the analysis not just of capitalist bureaucracy, but also of Communist authoritarianism. Williams goes on to reproach Lukacs for failing to fully apply this analysis, a repetition in another register of his constant complaint that Lukacs does not follow his own insights through to the issues most pertinent to socialist struggle. Lukacs's tendency to view the proletariat as an 'apocalyptic liberator' (The Guardian, 1971, Feb 25, p. 8) is an error, says Williams dismissively, which 'hardly needs emphasis' (p. 8). And yet, Williams concedes, 'in some of the most impressive pages he hits the real nerve' (p. 8). The crucial insight, Williams argues, is that 'if the working class is in one sense the product of capitalism, it will for a long time be subject to, and will even longer share, the modes of existence of its creator' (p. 9). This is indeed Lukacs's position, figured in terms of the continuing influence of reified forms of consciousness. He expresses the point with uncompromising vitriol in 'Towards a Methodology of the Problem of Organisation' (2010):

Lenin stubbornly insists on rejecting every utopian view of the human material with which the revolution must be made and with which the victory must be won: it consists necessarily of men who have been brought up in and ruined by capitalist society ... turned into something empty and abstract by the impossibility of finding satisfaction and of living out their personalities in their work ... which is now transformed into a brutal egoism greedy for fame or possessions ... The inner life of the party is one unceasing struggle against ... its capitalist inheritance. (Lukacs, 2010, p. 335)

Williams would not have endorsed any view of the working-class which described it as 'ruined', but he is keen, in his review, to distance Lukacs's perspective from those antisocialist critics who 'often make the easy point that whatever the theory may say, the practical consciousness of the working class is otherwise' (The Guardian, 1971, Feb 25, p. 8). 'Lukacs's account of the problem', says Williams, 'is more accurate in practice. He sees delay, deference, division, uneasiness as necessary but surmountable elements of the real historical development' (p. 8). Just as he had responded to Lukacs's awareness of experiential 
plurality in $M C R$, here Williams approves of the manner in which Lukacs's theory of class consciousness refuses to insist upon a determinate form of consciousness which follows predictably from the economic situation. At the same time, Williams challenges what he sees as Lukacs's unwillingness to connect the indeterminacy of class consciousness to the emergence of Communist bureaucracy: 'while he can then criticize social-democratic adjustments he does not go on to connect this precise phenomena to the emergence of communist bureaucracy and party dictatorship' (p. 8). This is a serious omission, says Williams, because it connects to the 'central controversy' (p. 8), which is that 'in the determinist and ordinary materialist theories of socialism, consciousness need not - ought not to - develop in that way: a change in the economic pace must be seen as changing consciousness predictably and directly, whether in practice it does so or not' (p. 8). The development which 'ought not to' occur here is the development of a consciousness from which arises the possibility of bureaucracy and party dictatorship. Williams charges Lukacs with seeing through the orthodox veil of mechanical materialism, but then failing to apply the resulting insights about the variability of class consciousness to the open possibility of adverse developments in revolutionary consciousness.

The justice of Williams's claims must be viewed as partial. Lukacs was certainly more willing to apply the 'stubborn reification' thesis to social democracy than to communism, but it is clear from the above quotation from 'Towards a Methodology of the Problem of Organisation' that Lukacs was well aware of the latter issue. The tendencies towards the mechanical objectification of man engendered by reification 'will necessarily persist in the Communist Party' says Lukacs, 'which after all has never claimed to be able to reform the inner nature of its members by means of a miracle' (Lukacs, 2010, p. 335). The practical realities of revolution, moreover, intensify these tendencies: 'the requirements of purposeful action also compel the Party to introduce the division of labour to a considerable degree and this inevitably invokes the dangers of ossification, bureaucratization and corruption' (Lukacs, p. 335). As a committed Leninist, Lukacs views both the problem of reification in revolutionary times and all possible solutions to it through the lens of the Party; although this is not the place to assess Lukacs's position in full, it can certainly be argued that his organizational strategies rely on a utopian faith in the 'living interaction between the will of the whole party and the Central Committee' (p. 339) and an inevitably hierarchizing recourse to 'iron discipline and ... [the] demand for total commitment' (p. 339) from Party members. While Williams (1971) neglects Lukacs's own formulation of the problem of Party 
dictatorship, he registers, more strongly than he did in the sixties, the tension in Lukacs's work between deviation from the Party line and unerring commitment to the Leninist model. Lukacs's analyses take us back, says Williams, not just to his 'originality, but to his no less important orthodoxy, as a Marxist intellectual, even more as a traditional intellectual' (1971, Feb 25).

Perhaps due to lack of space in his Guardian column, Williams leaves the question of the conceptual crux of Lukacs's argument, the distinction between 'actual' and 'imputed' class consciousness, to the essay 'Literature and Sociology' (2005f), written only a few months later as an ode to the deceased Goldmann. The immediate context of this discussion is important, since it concerns Williams's perception of the development of the sociological element in literary theory from the thirties up until the time of writing. Williams (2005f) notes the fact that young students throughout the sixties began to be drawn to the continental tradition and to what is referred to as 'theory', a word which 'suggests laws and methods, indeed a methodology' (p. 14). This turn towards alternative traditions and the 'rigour' of theory, says Williams, took place due to 'certain absolute restrictions in English thought, restrictions which seemed to link very closely with certain restrictions and deadlocks in the larger society' (p. 12). But there was then a danger of 'pseudo-theory' (p. 12), from which, Williams notes wryly, 'English thinkers could easily, too easily, fall back on their older habits, professing not to understand abstractions like a power structure though they could traditionally understand a microcosm ... not to know mediation although they knew catharsis' (p. 13). To complicate matters, thinkers like Goldmann were critiquing elements of their own tradition by critically acknowledging that 'the most available concept of laws, and from it the most available organizational methods, come in fact, from studies that are wholly different in kind: from the physical sciences, where the matter to be studied can be held to be objective, where value free observations can then be held to be possible' (p. 14). In the study of literature in particular, argues Williams, we encounter 'material so laden with values that if we do not deal directly [with them] we have literally nothing to deal with' (p. 14). Goldmann would have concurred, argues Williams, and notes that 'it is hardly surprising that in England it has been literary critics, and above all Leavis, who have led the opposition to what Goldmann calls "scientism", (p. 14). Williams (2005f) broaches this potential convergence of Leavisite practical criticism with the kind of critical continental approach represented by Goldmann only to dispel it: 
In his attack on 'scientism' [Goldmann] might for a moment have assumed that there were Cambridge allies, who had attacked the same thing in the same word. But this wouldn't have lasted long. Goldmann's attack of scientism - the uncritical transfer of method from the physical to the human sciences - was above all in the name of a critical sociology; whereas that word 'sociology' has only to be mentioned, in practical critical circles, to provoke the last sad look at the voluntarily damned. (p. 17)

Williams's disdainful attitude towards the inflexible specialism of practical criticism is clear here. In forgoing the scientistic attitude towards society and culture, practical criticism sought to position human values at the centre of literary production, an aim which Williams shared. But who would adjudicate the relation between text and values? The answer of Scrutiny, says Williams, 'was, as we know ... the informed critical minority' (p. 18). From this elitist critical perspective stems an interpretation of 'bad' literature, aesthetically defined, as a symptom of 'cultural decline' (p. 18), into which then slips the quasi-sociological 'wider social explanation: in this case the destruction of an organic society by industrialism and by mass civilization' (p. 18).

The notion of an anterior 'organic society' would seem to put the Leavisite conception at odds with Marxism, as indeed it did. At the same time, Scrutiny was effectively practicing a form of cultural criticism, and in this Marxism was a competitor, not an enemy:

In the 1930s [the Scrutiny] diagnosis overlapped, or seemed to overlap, with other radical interpretations, and especially perhaps, with the Marxist interpretation of the effects of capitalism. Yet almost at once there was a fundamental hostility between these two groups: a critical engagement between Scrutiny and the English Marxists, which we can have little doubt, looking back, Scrutiny won. But why was this so? (Williams, 2005f, p. 18)

Williams's answer to this forms the backbone of his critique of orthodox Marxism, and dictates the trajectory of his theoretical development as an attempt to work through the literary-critical contradictions of the thirties. 'Marxism, as then commonly understood,' Williams contends, 'was weak in just the decisive area where practical criticism was strong: in its capacity to give precise and detailed and reasonably adequate accounts of actual consciousness' (p. 19). Continental innovators like Lukacs and Goldmann came too late for the English Marxist of the thirties, the reason for whose defeat at the hands of Scrutiny, argues Williams, 'is not difficult to find: it lay in the received formula of base and superstructure' (p. 19). 
Williams (2005f) argued that the reductive reflection-theory characteristic of vulgar materialism 'left the field open to anybody who could give an account of art which in its closeness and intensity at all corresponded to the real human dimension in which works of art are made and valued' (p. 19). Into the breach stepped practical criticism, the result being a 'victory ... so crushing that in England, for a generation, even the original questions could hardly be raised' (p. 19). The pervasive language of warfare in Williams's descriptions (the thirties are described as an 'abandoned battlefield' to which Lukacs and Goldmann are now erroneously referred) underlines Williams's view of the literary culture of his own period as suffering from the effects of intellectual suppression by the victors. The belated English discovery of Lukacs and Goldmann points, for the Williams of 'Literature and Sociology', towards the possibility of renewing the vitality of literary debate, and of disrupting the hegemony of a set of positions which, in the name of a humanistic fidelity to experience, was neglecting the necessary analysis of society as a totality. But then, if a fresh volley was to be loosed against the establishment, it could not be by using the same theoretical arsenal as was employed by the losing faction in the thirties. Marxist criticism would have to be radically reformed, even if this meant, as it sometimes did, a qualitative disconnection from what had been the core insights of the tradition. The project of The Long Revolution, says Williams (2005f), had been 'to replace the formula of base and superstructure with the more active idea of a field of mutually if also unevenly determining forces' (p. 20) i.e. totality. It was in this same early sixties context that Williams first encountered Lukacs and Goldmann and, in a sense, rediscovered Marxism via the continent: 'it is easy to imagine my feelings when I discovered an active and developed Marxist theory, in the work of Lukacs and Goldmann, which was exploring many of the same areas with many of the same concepts, but also with others in a quite different range' (p. 20). The context in which Williams is receiving the ideas of Lukacs and Goldmann is thus crucial to the mode in which he receives them, and the purposes he wishes to serve in doing so. They point, for him, towards the possibility of a Marxist framework which disavows, or at the very least confronts, the disastrous hegemony of base/superstructure.

For Williams (2005f), the 'real advance' (p. 20) in the work of both Lukacs and Goldmann consists in the discussion of reification, this being for him 'the dominance of economic activity over all other forms of human activity, the dominance of its values over all other values ... so that this reification, this false objectivity, was more thoroughly penetrating every other kind of life and consciousness' (p. 21). Against this phenomenon Williams, with 
Lukacs and Goldmann, deploys the perspective of totality: 'The idea of totality was then a critical weapon against this precise deformation; indeed, against capitalism itself' (p. 21). But there is a crucial conceptual difference between Williams and the continental tradition he is attempting to converse with. The totality, for Williams, is a totality of experience or, as he puts it in the same essay, a 'totality of consciousness' (p. 22), an interlinked spectrum of responses, old and new, to reality. Criticism will intuit the various individual and collective responses to elements in a 'whole way of life', marking a break from all theories of singular determination in culture and aesthetics. For Lukacs, conversely, the totality is objective, a statement of absolute ontology, to which consciousness will in one way or another, with or without fidelity, relate. Moreover, the Lukacsian totality is specifically determinate along orthodox Marxist lines; the ontology of the totality depends first and foremost on the mode of production and developments in the class struggle. Williams does not quite seem to intuit, at this stage, the magnitude of the difference between his own conceptions and those of the continental writers (especially Lukacs) with whom he finds common cause. This becomes clearer still in his description of the difference between actual and imputed or possible consciousness:

Goldmann, following Lukacs, distinguishes between actual consciousness and possible consciousness: the actual, with its rich but incoherent multiplicity; the possible, with its maximum degree of adequacy and coherence. A social group is ordinarily limited to its actual consciousness, and this will include many kinds of misunderstanding and illusion: elements of false consciousness which are often, of course used and reflected in ordinary literature. But there is also a maximum of possible consciousness: that view of the world raised to its highest and most coherent level, limited only by the fact that to go further would mean that the group would have to surpass itself, to change into or be replaced by a new social group (Williams, 2005f, p. 23).

What emerges in the course of the subsequent analysis is a mapping of the actual/possible distinction onto something like the dominant and emergent strains (in Williams's later terminology) of a cultural hegemony. The distinction is useful, Williams argues, to the degree that it breaks with the received dogma of base and superstructure and permits the division of conscious responses to reality between those which conform to the 'common illusions' (p. 24) of a 'world-view, a particular and organised way of seeing the world' (p. 24) and those which, in their 'simultaneous realisation of and response to these underlying and formative structures' (p. 24), permits the 'imaginative act, the imaginative method, the specific and genuinely unprecedented imaginative organisation' (p. 25). Actual consciousness is linked 
here to the idea of a dominant world-view, while possible consciousness plays the part of a potentially subversive, or at least progressive, element of emergent response. But then what is the reader to make of the claim, in the above quotation, that possible consciousness is also 'that [dominant/actual] view of the world raised to its highest and most coherent level'? How can the highest and most coherent expression of a dominant world-view be synonymous with its transgression?

The problem here, which gives rise to numerous confusions, is that Williams is using the terms 'actual' and 'possible' consciousness as though the latter were an intensification of the former; actual consciousness is the consciousness a given social group actually has, while possible consciousness is that condition raised to the nth degree, to the point where to surpass it would be to pass through the border of what is possible for that particular group at that particular stage in its development. From this conception arises Williams's tendency to see 'possible' consciousness as a kind of 'going beyond', a transgressing of dominant responses and their organisation. But then this is in some respects the exact opposite of what Lukacs meant by these terms, and points towards the vast semantic gulf between Williams's 'possible' and Lukacs's (as he is most commonly translated) 'imputed' (zugerechnet). By 'actual' consciousness, Lukacs had meant a relatively indeterminate, perhaps even 'inappropriate', form of consciousness, precisely by its opposition to 'imputed' consciousness, that being 'the thoughts and feelings which men would have in a particular situation if they were able to assess both it and the interests arising from it in their impact on immediate action and on the whole structure of society' (Lukacs, 2010, p. 50); in short, their objective class situation. Williams is right, therefore, to suggest that the distinction points towards at least a partial break with base and superstructure, since actual consciousness need not necessarily follow the contours of imputed consciousness; real, psychological attitudes are not determined straightforwardly by class position. He is wrong, however, to suggest that 'possible' consciousness, in anything like its Lukacsian formulation as 'imputed', reaches towards the transgressive heights of new experience and the artistic spontaneity of the novel response. Possible or imputed consciousness is, in Lukacs, that form of consciousness which most closely follows the contours of the economic position.

Again, the crux of the matter is Williams's principled refusal to acknowledge the determining force of a 'pre-existent social reality' structured economically around the mode of production and its class effects. What he sees as the point of fruitful theoretical development in Lukacs is 
an analysis of consciousness which refuses to chain consciousness deterministically to an economic base; Lukacs does indeed unchain consciousness, but for him this means that there now exists a disjunction between consciousness and reality which must be explained and ultimately repaired. False consciousness represents the inability of human beings to understand their position within an objective historical complex of social relations; the role of historical materialism is therefore to restore the link between reality and consciousness which, in the orthodox interpretation, will lead to the working-class asserting its interests and abolishing class society. Williams simply does not attend to false consciousness as a category in this sense. When he speaks of reification, which is the name Lukacs gives to the economic process whereby false consciousness is instantiated, Williams (2005f) refers, as we have seen, to 'the dominance of economic activity over all other forms of human activity, the dominance of its values over all other values' (p. 21). But insofar as these economistic values are judged negatively, it is because they are, from Williams's avowedly socialist perspective, perilous to human eudaimonia, not because they are the values of people who have become incapable of perceiving adequately the exploitative basis of capitalist social relations.

Williams concludes his discussion of actual and possible/imputed consciousness with the following remarks, worth quoting at length, in which he stresses both the utility of the distinction (as he has interpreted it), and its limitations:

We must reject those versions of consciousness which relate it directly, or with mere lags and complications, to a determining base. The stress on an active consciousness made by Lukacs and Goldmann may give us a real way beyond that. And it might be possible to say that the relation I have tried to describe - between formal consciousness and new creative practice - might be better, more precisely, described in their terms: actual consciousness and possible consciousness. Indeed I hope it may be so, but I see one major difficulty. This relation, though subtle, is in some ways static. Possible consciousness is the objective limit that can be reached by a class before it turns into another class, or is replaced. But I think this leads, rather evidently, to a kind of macro-history: in many ways adequate but in relation to actual literature, with its continuity of change, often too large in its categories to come very close, except at certain significant points when there is a radical and fundamental moment of replacement of one class by another (2005f, pp. 25-26).

I hope I have shown that what Williams's distinction between the residual/dominant and emergent strains in a culture or a structure of feeling may not, in fact, be described in Lukacs's terms, unless those terms are made to mean something quite different. This does not, of course, invalidate either thinker's formulations, but it does, I think, render them very 
far even from being commensurable for the purposes of immediate comparison; Williams's conception refers to the conditions for the emergence of novel creative responses in artistic production, while Lukacs's refers to the capacity of particular classes to adequately perceive their material interests as part of an existing (and knowable) social totality. The confusions to which Williams's own conflation of these apparatuses give rise are sometimes quite grievous, but they are also instructive with regard to his development. Williams's error nevertheless reveals the trajectory he is trying to map out. What he is seeking to establish, in the latter part of the quotation, is the degree to which emergent strains are always and everywhere arising as part of the normal development of consciousness; their emergence is not limited to those few historical junctures (in practice, revolutionary conjunctures) in which classes cease to exist or are superseded. Because of the way in which he has interpreted Lukacs, Williams sees the actual/possible distinction as the first step in bringing criticism to the point of acknowledging the fluid, transformative nature of literary production. Lukacs's formulation remains problematic, however, in its inability to detach artistic creativity from class position, the result being a 'macro-history', a history viewed at an unhelpfully high level of abstraction and generalization which fails to acknowledge the granular mechanisms of cultural development. The appreciation of granularity, of course, was precisely what Scrutiny did well; the lack of it in the Marxist theory of the thirties was, in Williams's analysis, the source of its defeat at the hands of practical criticism and the ensuing (and enduring) paralysis of literary debate.

Again, for the sake of theoretical rigour, it must be pointed out that Williams is incorrect in his appropriation of Lukacs here. The class basis of possible/imputed consciousness does not render it an inadequate vehicle for emergent acts of creative imagination; it is neither a vehicle for such acts nor their negation. For Lukacs, whether or not a literary production is 'novel' (in the sense of reflecting an emergent response to social reality) is irrelevant to whether that same production is linked to the imputed class consciousness of its author. Novel instantiations of the creative imagination may proceed from both imputed and actual consciousness without distinction. What matters for Lukacs is whether or not such novel productions follow the contours of reality (which itself will change, offering up new material to be responded to) or submit to forms of false consciousness. These are complex issues which I will continue to draw out in the final two sections of this chapter. The salient point here is that Williams is appropriating Lukacs despite his flawed conception of the theory of actual and imputed consciousness. Conceiving of 'possible' consciousness as an index of 
emergent strands in a structure of feeling arguably makes Lukacs into more of an influence than he deserves. But Lukacs's complex model of consciousness does mark a break with simple reflection theory, opening the door as it does so to responses beyond the dominant ideological nexus. Williams's is not wrong, then, to appropriate Lukacs for the revival and extension of Marxist theory in the literary-critical context of the early seventies.

It should be noted that Williams (2005f) does not hold back in his criticisms of the specific failings of Lukacs and Goldmann's literary criticism, and indeed he links these back to what he understands as their Marxism. He complains, justly, that in Lukacs 'No English novels are considered at all' (p. 26), and accuses him of coming to such sweeping conclusions as that 'the novel is the form in which, in a degraded society, an individual tries and fails to surpass an objectively limited society and destiny' (p. 26) from material 'so extremely selective that we are almost at once on our guard' (p. 26). The idea of an inattention to granularity on Lukacs's part comes through here again, and Williams develops this into a critique of Lukacs and Goldmann's conception of literary form: 'form, in Lukacs and Goldmann, translates too often as genre or kind ... we stay, too often, within a received and ultimately idealist tradition in which 'epic' and 'drama', 'novel' and 'tragedy', have inherent and permanent properties, from which the analysis begins and to which selective examples are related' (p. 27). Of course, one of Lukacs's central concerns had been to distinguish the novels of high realism from the 'decadent' novels of the modernists; while Williams is cognizant of such appreciations of formal development and change ('Lukacs makes ... distinctions, from Balzac through Mann and Kakfa to Solzhenitsyn' (p. 27)), he insists that the issue of form is still confused by an 'undiscarded ballast of form in a more abstract, more supra-historical sense' (p. 27). Whether this 'undiscarded ballast' is indeed supra-historical is a larger issue that cannot be properly addressed here; what is at least clear is that Lukacs's distinctions are based firmly in class. For Williams, who could not accept what he saw as the 'macrohistorical' implications of the class theory of consciousness, the repetition of such a macrohistory in the analysis of literary form is equally unacceptable.

For Williams in the early seventies, then, Lukacs (with Goldmann), repurposed for a less orthodox Marxism, itself aware of the theoretical and strategic failings of base/superstructure, represent an opportunity to provide literary theory with a sociological dimension sorely lacking in practical criticism. Despite his misappropriation of some key categories, Williams's commentary is keener and more detailed than was possible during his first 
encounters with Lukacs in the early sixties. The reservations Williams has at this stage fail to mar his enthusiasm for the potential enlargement of literary debate which the increasing availability of Lukacs's work in English is making possible. In the remaining sections of this chapter, I want to bridge the gap between the Williams of 1971, who still regards Lukacs as a necessary addition to the arsenal of a materialist criticism, and the Williams of 1984, for whom the developed theory of cultural materialism is not a different, not a partial, but a 'diametrically opposite answer to the questions which Lukacs and other Marxists have posed' (1984a, p. 15 - my emphasis).

\section{Cultural Materialism and the Break with Lukacs}

The period 1977 to 1984 marks the phase of William's most robust engagement with Lukacs's work. 1977 sees the publication of Marxism and Literature, Williams's first systematic articulation of the theory of cultural materialism, in which he develops his position on the nature of class consciousness and addresses Lukacs's notions of 'typicality' and the 'specificity of the aesthetic'. In the Introduction to $M L$, Williams develops the contextual themes touched on in 'Literature and Sociology' with a more explicit statement of affinity to the European intellectual ferment that had inspired him in the sixties and early seventies. The 'model of fixed and known Marxist positions', says Williams, 'which in general had only to be applied, and the corresponding dismissal of all other kinds of thinking as non-Marxist, revisionist, neo-Hegelian, or bourgeois' (p. 2) was, mercifully, over. The deadlock of the thirties which Williams had described in 'Literature and Sociology' was, in this period of significant cultural and intellectual transmission, 'being vigorously and significantly reopened' (p. 4), and Williams positions his own work as embedded in this vital new conjuncture. How does Lukacs, who is after all one of oldest of the new European references, fit into this vibrant, emergent scene? For Williams, it is as the progenitor of certain categories and approaches which, while crucial in the early development of the new Marxism, must now be decisively superseded. Even in 1972, it had been Goldmann (having developed and nuanced Lukacs's categories) who represented the greatest advance; in the broad period of ML, $P L$ and Culture, Williams's critique of Lukacsian categories is extended and the distance between his own and Lukacs's positions is made more explicit. While the mid-to-late seventies was the period of Williams's most explicit affirmation of his work as Marxist, it was also the period of his most concerted critique of, as he put it in 1972, 'what [had] come down to us as Marxism' (The Listener, 1972, March 23). Alongside the seminal critique of 
base and superstructure, the term 'cultural materialism' drew its meaning from opposition to the closely related 'epochal' construction of historical materialism which had, in Williams's view, divided the 'whole and indissoluble material and social process' (2009 [1977], p. 68) beyond recognition.

One of the unifying themes of Williams's commentary in this period is his resolute opposition to any 'epochal' analysis of history and its 'corresponding' forms of consciousness and literary production. This position had already found expression in the early seventies in Williams's critique of the 'macro-historical' implications of Lukacs's classtheory of literature. In Marxism and Literature Williams (1977) turns his attention to the notion of ideology, in particular its usage as 'an abstraction ... a category of illusions and false consciousness ... given a categorical rigidity, an epochal rather than a genuinely historical consciousness of ideas, which could then be separated into ... successive and unified stages' (2009, p. 67). Here Williams opposes an epochal conceptualization of ideology, in which particular (false) ideas and forms of consciousness mechanically correspond to particular historical periods, to a 'genuinely historical' conception, centred in 'Marx's emphasis on a necessary conflict of real interests' (p. 67). An authentically Marxist (materialist and historical) definition of ideology would, Williams argues, be one in which the term 'reverts to a specific and practical dimension: the complicated process within which men "become" (are) conscious of their interests and their conflicts. ${ }^{55}$ The categorical shortcut to an (abstract) distinction between "true" and "false" consciousness is then effectively abandoned, as in all practice it should be' (p. 68).

Does the rejection of the abstract and categorical simplification of consciousness as an 'epochal' phenomenon demand the rejection of the distinction between 'true' and 'false' consciousness? The manner in which Williams brings Lukacs into the discussion clarifies his intention. The conflation of ideology with 'false consciousness', says Williams, 'has always prevented the more specific analysis of operative distinctions of 'true' and 'false' consciousness at the practical level, which is always that of social relationships' (2009 [1977], p. 68). The epochal or macro-historical approach, then, with its rigid taxonomies of true and false forms of consciousness and their iron-clad historical determinants, fails to

\footnotetext{
${ }^{55}$ Williams's analysis here is clearly indebted to Thompson's analysis of class (or class formation) in $T M E W C$ (1963), where he states that 'class happens when some men, as a result of common experiences (inherited or shared), feel and articulate the identity of their interests as between themselves, and as against other men whose interests are different from (and usually opposed to) theirs' (2013 [1963], pp. 8-9).
} 
account for consciousness at the level of the complex and particular social relationships in which men and women find themselves and locate their experiences. Lukacs, Williams suggests, had attempted to "clarify this analysis by a distinction between "actual consciousnesses" and "imputed" or "possible" consciousness (a full and "true" understanding of a real social position)' (p. 68). The clarification, Williams implies, lies in the fact that imputed consciousness (Williams now includes the more common term), being a 'full and true understanding of a real social position' (p. 68), points towards a more complete, complex or nuanced ('granular') apprehension of real social relationships; 'This has the merit', he argues, 'of avoiding the reduction of all "actual consciousness" to ideology' (p. 68).

In what sense does distinguishing 'imputed' from 'actual' consciousness avoid the stated reduction of actual consciousness to 'ideology' (false consciousness)? Only in the sense that actual consciousness, on this reading, is an 'incomplete' form of consciousness, in which case it must contain elements that do not follow mechanically from the particular ideological formation associated with the corresponding imputed consciousness. But here Williams is repeating the mistake he made in 'Literature and Sociology', namely, that imputed consciousness is a more 'complete' or 'full' version of actual consciousness. Lukacs is clear on this: imputed consciousness is awareness of interests, nothing more or less. On Williams's reading, actual consciousness isn't so much 'false' as contingent, and therefore potentially subversive; it cannot be reduced to mere 'bourgeois ideology' and may therefore, in being made more coherent, be raised to the level of totality. For Lukacs, however, what determines whether or not consciousness is true or false isn't 'coherence' but class, and the relation of a class to reality as described by historical materialism. To clarify Lukacs's position: actual consciousness is the consciousness of a class (or individuals within a class) which does not properly understand its class position and the interests proceeding from it. Whether or not such a consciousness is true depends on the relation between it and reality; in practice, this means whether or not it examines the social totality from the 'correct' perspective of historical materialism. By definition, the bourgeoisie cannot do this; its imputed consciousness is false, since it is not historical materialist (this is because a historical materialist view would insist upon the overthrow of class society, which the bourgeoisie cannot condone). Proletarian 'actual' consciousness will usually be false, as when proletarian individuals fail to understand their class position, but imputed proletarian class consciousness is true; it views reality 'correctly' via historical materialist theory and, by understanding its 
own interests in the overthrow of class society, which it can and must condone, is capable of realizing, in both thought and action, the 'truth' of history.

Now, Williams is aware of the thrust of this view of the 'truth' of proletarian class consciousness, and indeed this awareness forms the backbone of what is, in $M L$, a stronger condemnation of Lukacs's theory than is mounted in the early seventies. While the distinguishing notion of 'imputed' consciousness rescues actual consciousness from mere falsehood, Williams argues, 'the category is speculative, and indeed as a category cannot easily be sustained' (2009 [1977], p. 68). The reason is that, 'In History and Class Consciousness it depended on a last abstract attempt to identify truth with the proletariat, but in this Hegelian form it is no more convincing than [positivist, bourgeois abstraction]' (p. 68). Lukacs criticizes himself in similar terms in the 1967 Preface to HCC, in which he says that by imputed class consciousness he had meant 'the same thing as Lenin in What is to be done? when he maintained that socialist class consciousness would differ from the spontaneously emerging trade-union consciousness in that it would be implanted in workers "from outside", (Lukacs, 2010, xviii), i.e. by professional Marxist revolutionaries. This, Lukacs goes on, 'was transformed in $[H C C]$ into a purely intellectual result and thus into something contemplative. In my presentation it would indeed be a miracle if this 'imputed' consciousness could turn into revolutionary praxis' (xix). What is then interesting is that Williams, while cognizant of the class-basis of Lukacs's account, and while substantially agreeing with Lukacs's later self-criticism, nevertheless retains a conception of the actual/imputed distinction which strips it of its grounding in the dialectic 'class/reality' and makes of it a measure of the solidity or coherence of the world-view of a 'social group'. The attribution of 'true' or 'false' consciousness to such a group falls outside of the purview of class analysis. He firmly rejects Lukacs's distinction, then, but only after presenting it as a necessary step forward (now to be superseded) in the development of Marxist theory, a characterization which is only tenable for Williams on the basis of a misunderstanding of its real import.

If I labour the point about Williams's misreading of Lukacs, it is in no way to declare Williams's analysis, or indeed his general position, inadmissible by virtue of it; I insist on acknowledging his error only to bring into sharper focus the gulf that separates his late work from that of Lukacs. This is so much so, I have been arguing, that Williams primarily finds himself in agreement with Lukacs where he misunderstands him, and yet that very 
misunderstanding marks a sequence of points in Williams's development in which he feels able to trace the contours of a new theoretical conjuncture. As the strength of Williams's critique intensifies in the late seventies, the erroneous appropriation of Lukacs becomes less important, and the criticisms, which are often relatively autonomous (the errors having functioned mainly to increase Williams's esteem for Lukacs), come to the fore. I turn now to Williams's critique of Lukacs's late aesthetic theory in $M L$ and in Culture, before, in the final section, addressing $P L$ and Williams's later reviews.

I have argued that Williams is drawn to Lukacs, throughout his career but particularly in its middle phase, by the promise held in Lukacs's work of a resolution of the deadlock of the thirties: a 'third way' between the over-specialized and elitist practical criticism of the Scrutiny tradition, and the dogmatic reflection theory of a certain kind of orthodox Marxism (Caudwell). Another way of stating this same distinction is as that between a Platonic aesthetics, which made of art and literature a repository of pure human values floating above and beyond a 'fallen' industrialised society (Leavis), and a vulgar materialist aesthetics which subsumed art into an abstractly categorised totality of economic forces which art could only 'reflect', 'mimic' or otherwise ape. Williams shared with this orthodox Marxist position a positive conception of totality, the 'whole social and material process', but then the central issue was to avoid importing into the totality concepts which deviated from what was always, in Williams, a granular stress on the real material bases of social life. Theories, among which we may include both practical criticism and Marxist reflection theory, which separated art and artistic expression out from the whole social and material process as something secondary, perhaps even immaterial, could not be accepted; as Williams put it in 'Literature and Sociology', 'the whole point in thinking in terms of a totality is the realization that we are part of it; that our own consciousness, our work, our methods, are then critically at stake' (2005f, p. 21). Both practical criticism and orthodox Marxism failed to include artistic creativity within the totality at all, leading either to a denial of the real totality ('art is transcendent and separate from the world'), or the impoverishment of both the totality and art ('art, being "merely" superstructural, is not a part of the real foundation of society').

This conceptual dialectic, which Williams sought to sublate, reappears in his treatment of Lukacs's late aesthetic theory. In $M L$, Williams argues that the history of the word 'aesthetic' 'is in large part a protest against the forcing of all experience into instrumentality ('utility') and of all things into commodities' (2009, p. 151). This 'humane response' (p. 151), which 
recalls the emphasis of Scrutiny, used the idea of the aesthetic to communicate 'an affirmation, directly comparable with the definition and affirmation of "creative imagination", of certain human meanings and values which a dominant social system [industrial society] reduced and even tried to exclude' (p. 151). If this was an attempt to guard art against the ravages of capitalist instrumentality, then so too, says Williams, has been a Marxist 'tendency, centred on Lukacs, to distinguish and defend "the specificity of the aesthetic"' (p. 151) in internal opposition to the unhelpful 'reduction of art to social engineering (“ideology”) or superstructural reflection' (p. 151). If the 'humane response', in its transcendentalism, positions art above the social world, and the traditional Marxist response reduces art to either ideology or reflection, where does the Lukacsian effort, here explicitly formulated as an attempt to bypass this false dichotomy, go wrong in assigning to art a specific location? 'Lukacs sought to define art', says Williams, 'in ways which would distinguish it, categorically, from both the "practical" and the "magical"" (p. 151). By practical, says Williams, is meant 'containment within specific historical forms: for example the reduced practice of capitalist society' (p. 151) whereas the 'magical' or 'religious' 'offer their images as objectively real, transcendent, and demanding belief' (p. 151). Williams then offers the following summary of Lukacs's view of the 'aesthetic' category, which stands in opposition to the other two:

Art offers its images as images, closed and real in themselves (following a familiar isolation of the 'aesthetic'), but at the same time represents a human generality: a real mediation between (isolated) subjectivity and (abstract) universality; a specific process of the "identical subject/object"”. (2009 [1977], p. 151)

Williams's response is balanced, but reaches a verdict:

This definition is the strongest contemporary form of the affirmation of genuine 'aesthetic' practice as against a reduced 'practicality' or a displaced 'myth-making'. But it raises fundamental problems. It is, intrinsically, a categorical proposition, defensible at that level but immediately subject to major difficulties when it is taken into the multiple world of social and cultural process ... The problem is to sustain such a distinction through the inevitable extension to an indissoluble social and material process: not only indissoluble in the social conditions of the making and reception of art, within a general social process from which these cannot be excised; but also indissoluble in the actual making and reception, which are connecting material processes within a social system of the use and transformation of material (including language) by material means. (2009 [1977], p. 152) 
In 'reduced practicality' we hear echoed the 'ideology' and 'reflection' of the Marxism to which Williams is opposed; in the 'displaced myth-making' we can intuit the transcendental elitism of Scrutiny and practical criticism. The specific failing of Lukacs's alternative is that it is 'categorical', a word symbolizing the same kind of analytic taxonomy that Williams opposed in Lukacs's 'epochal' analysis of literary form. The categorical nature of the specificity of Lukacs's aesthetic cannot survive what Williams suggests would be a more probing and complex analysis of human activities as they really, that is, indissolubly, exist. The totality is a more severe one, for Williams, than it is even for Lukacs (long considered the foremost thinker of totality), a 'general social process' within which all forms of human creative activity ('practical' labour, 'magical' idealisation, 'aesthetic' creation), are so closely interwoven that categorical pronouncements are always insufficient, even as the complexity of the totality demands their most probing examination and description.

Williams's point is well made, and indeed a certain degree of categorical unraveling is unavoidable as soon as the critical gaze turns towards such liminal objects/practices as 'religious art' or 'artisanal manufacture'. But then, Lukacs's distinctions do not refer to the specific 'empirical' differences between activities but to the relation between subject and object, and to the possibility of the dissolution of that opposition (that opposition being the essence of alienation) in certain, quite contingent, creative situations; there is no necessary reason why certain kinds of manual labour or religious worship may not, indeed, be regarded as 'aesthetic' in Lukacs's terms. The explicit categorization of such human practices nevertheless comprises, for Williams, another example of Lukacs's inattention to the complexity of, as it stood in 'Literature and Sociology', the 'field of mutually if also unevenly determining forces' (2005f, p. 20). Williams expresses the same point with greater clarity in Culture (1981), and touches once again on the distinction between the historical and the categorical (or 'epochal'):

Too many processes and objects from the 'practical' and 'magico-religious' phases come to demand inclusion in the 'aesthetic' phase. Too many 'aesthetic' processes and objects overlap, in practice, with the 'practical' and 'magico-religious'. It is indeed the relative integrity of these phases, in certain periods of human practice, which allows us to see certain subsequent specializations, in periods of altered general practice, as historical rather than categorical facts (and the theory of Lukacs, in terms, as idealist rather than historical materialist). (1983a, p. 128) 
This is an important passage because it contains, in microcosm, the full kernel of Williams's disagreement with Lukacs's general perspective. 'Specializations', here of different kinds of (ultimately indivisible) human practice, are revealed, in the occasional integrity of their manifestations, to be responding to fluid, historical circumstances. An 'epochal' focus, on the other hand, is only capable of analyses in which the character of the phenomena in question is para- or extra-historical i.e. grouped according to non-historical criteria. From this opposition of the categorical and the historical (the categorical becomes 'epochal' in analyses aiming at historicity), Williams moves to the opposition between idealist and historical materialist thought, and maps the first opposition onto the second. The categorical analysis (Lukacs's), being based upon speculative, extra-historical criteria, is 'idealist'; it is de-linked from the 'whole material and social process' which, for Williams, is the totality. A properly historical materialist analysis, by contrast, would attend to the precise historical character of the creative response and account for it in terms of a general structure of responses (a structure of feeling with residual, dominant and emergent aspects) to the broader conjuncture.

If I were to argue, citing as evidence Marx's famous statement that 'the history of all hitherto existing society is the history of class struggles' (2008, p. 3), that Marxism is above all a class theory of history, then it is true that there is nothing particularly Marxist about Lukacs's distinction of the aesthetic from other forms of human creative practice. It is certainly 'dialectical', in positing the possibility of the synthesis of subject and object in aesthetic sublation, but it does not in itself go beyond dialectical idealism of a Hegelian kind. Williams is therefore quite right, from a Marxist perspective, to insist on placing aesthetic production back into the complex of specific material social processes as they unfold historically, and in criticizing Lukacs for failing to apply the insights of historical materialism in his account. But if Marxism is indeed a 'class theory of history', then the charge must also be leveled at Williams that his own account, while more 'materialist' in a basic sense, omits the category of class (replaced by the 'social group') almost entirely, a charge which could not be leveled at Lukacs's literary criticism of the thirties. What Lukacs's earlier criticism, and indeed HCC, shares with the founding doxa of Marxism is a) a materialist and class-based theory which is 'epochal' and 'categorical' because based on categorical distinctions between classes and an epochal-class theory of history and b) an insistence on 'truth' and 'falsity' as operative categories upon which social and economic analyses may be based and by reference to which criteria it should be possible, at least in theory, to assess the consciousness of individuals and classes. Even if Lukacs firmly continues only b) into his later aesthetic work, the lack of a 
commitment to class analysis in Williams, and of the 'categorical-epochal' analyses which Marxism thereby tends to erect, which remains the most fundamental difference between the two thinkers.

Remaining on the terrain of the aesthetic, consider in this light Williams's assessment, in Marxism and Literature, of the ideological content of the separation of the aesthetic from other forms of human practice:

We can then see more clearly the ideological function of the specializing abstractions of 'art' and 'the aesthetic'. What they represent, in an abstract way, is a particular stage of the division of labour. 'Art' is a kind of production which has to be seen as separate from the dominant bourgeois productive norm: the making of commodities. It has then, in fantasy, to be separated from 'production' altogether; described by the new term 'creation'; distinguished from its own material processes; distinguished, finally, from other products of its own kind or closely related kinds - 'art' from 'nonart'; 'literature' from 'para-literature' or 'popular literature'; 'culture' from 'mass culture'. The narrowing abstraction is then so powerful that, in its name, we find ways of neglecting (or of dismissing as peripheral) that relentless transformation of art works into commodities, within the dominant forms of capitalist society. (2009, pp. 153-154)

Williams implicates both the Scrutiny tradition and the new Marxist aesthetic emphasis of Lukacs in what is ultimately theorized as a malign ideological current: the separation of art from other kinds of productive activity. This, argues Williams, perpetuates an elite division of labour, divorces the making of art from its constituent material processes and obscures the ongoing commodification of art behind a veil of romantic transcendentalism. From the explicit signaling of the 'productive norm' as having its basis in class ('bourgeois'), to the emphasis on a form of ideological manipulation which obscures the real processes at work, this is a suggestive analysis with all the hallmarks of a Marxist criticism. At the same time, however, the 'abstraction' (the specificity of the aesthetic) is sociologically indifferent; 'we', not members of any particular class, or for reasons pertaining to the kinds of consciousness available to particular classes, neglect the commodification of art. Williams's analysis takes reification, interpreted as 'the dominance of economic values over all other values', to be a driving force behind the aesthetic abstraction. For Lukacs, however, reification is not a set of 'economic values' to which 'we', as an undifferentiated social subject, pay tribute by our collective consciousness; it is an illusion thrown up by the capitalist mode of production, which is absolutely false from an epistemological standpoint, and which persists as the ideological form of the interests of the bourgeois class and the ideological antithesis of the 
interests of the working class, who alone are capable, in their revolutionary activity, of 'practically' apprehending the underlying totality.

I have been arguing that Williams appropriates Lukacs for the purposes of resolving the contradictions of the thirties and rejuvenating Marxist criticism, and that this proceeds alongside some severe misunderstandings and a gradual intensification of Williams's own awareness of the distance between his own position and Lukacs's. All of this occurs in parallel with the development of Williams's own materialist theory, which aims at historicity by cleaving to an indissoluble and indivisible totality designated variously as a 'whole way of life', a 'structure of feeling', the 'totality of consciousness', the 'field of mutually if also unevenly determining forces', and ultimately 'culture' itself. 'Cultural materialism' formulates culture not as an abstraction or an idealization opposed to 'industrial society', nor as a rarefied metaphysical property of the identical subject-object, but as a material process like any other, wholly integrated and as fluid as the conception of history to which Williams subscribes. It seems perverse to argue that Williams's model ought not to be described as a 'historical' materialism, since it is evidently sensitive to history, to change and transformation, to the evolving character of the totality. But if historical materialism is to mean Marxism, then Williams is indeed propounding a cultural, and not a 'Marxist' materialism, since Marxism at its best has not been about ontology, but about causation, and it is in this precise sense that Marx's is a 'historical', as opposed to a 'philosophical', materialism. Eagleton (2007a) expresses this point clearly in his 'Base and Superstructure in Raymond Williams':

There is a strong implication throughout much of Williams's later work that to label a phenomenon 'superstructural' is somehow to assign it a lesser degree of effective reality than an element of material production ... The specificity of the base/superstructure thesis lies not here, but in the question of determinations. It is not a thesis which is out to distinguish the more from the less material, perhaps categorizing some phenomena as 'material' and some as 'spiritual' or 'ideal'. It is a conceptual instrument for the analysis of forms of material determination in particular historical societies, for the ends of political practice. Williams's concept of 'cultural materialism', by contrast, threatens to return to an essentially philosophical emphasis. (Eagleton, 2007a, p. 168)

Of course, even were Williams to accept that historical materialism does not aim at dividing material from ideal, real from 'less real' (and in a variety of places he does acknowledge this) he would still be disinclined to assent to any 'global' or 'total' theory of determination in the 
sense which Marxism can purport to be. There are undoubtedly versions of the base and superstructure thesis which, when sufficiently sensitive to historical specificity and when theoretically buttressed by the less controversial claim that 'social being determines consciousness', offer, for the committed historical materialist, ways out of the difficulties which Williams identifies. ${ }^{56}$ But there is then the question of whether Marxist cultural theory can survive Williams's pivot away from the idea of an 'articulated' totality, ${ }^{57}$ or whether the fully specific, fully granular model Williams advocates requires instead a broader discipline: a 'sociology of culture'.

For now, let us turn to Edward Said, whose essay 'Travelling Theory' (1983) offers a model of intellectual transmission, reception and even transformation, across time and space, and illustrates this via what he sees as a kind of lineage from Lukacs, through Goldmann, to Williams. This was a lineage which, as I have said, Williams was ultimately to renounce; Said's analysis nevertheless remains useful as a tool for orienting Williams's engagement with Lukacs in time and space, and to explain more concretely the process of partial appropriation of Lukacs's ideas in which Williams was engaged.

\section{Travelling Theory}

Said's (1983) analysis is guided by the idea that, when addressing cross-cultural and crossgeographic appropriations of theoretical constructions, it is proper to ask 'whether by virtue of having moved from one place and time to another a theory gains or loses in strength, and whether a theory in one historical period and national culture becomes altogether different for another period or situation' (p. 226). For all the contingent complexity of such movements, Said argues, there persists across a multitude of examples 'a discernable and recurrent pattern' (p. 226) comprising four rough stages:

First, there is a point of origin, or what seems like one, a set of initial circumstances in which the idea came to birth or entered discourse. Second, there is a distance traversed, a passage through the pressure of various contexts as the idea moves from an earlier point to another time and place where it will come into a new prominence. Third, there is a set of conditions - call them conditions of acceptance or, as an inevitable part of acceptance, resistances - which then confronts the transplanted

\footnotetext{
${ }^{56}$ Indeed, as I argue in Chapter Three, pp. 196-206, Williams's own work on hegemony in the seventies offers precisely such a model.

${ }^{57}$ A conception of the social totality as being 'articulated' in determinate ways was, for Hall in 'Cultural Studies: Two Paradigms' (1980), one of the strengths of structuralist over culturalist analysis.
} 
theory or idea, making possible its introduction or toleration, however alien it might appear to be. Fourth, the now full (or partly) accommodated (or incorporated) idea is to some extent transformed by its new uses, its new position in a new time and place. (1983, pp. 226-227)

The most striking thing about this passage is its debt to Williams's triad of the residual, dominant and emergent, here mapped onto cross-cultural processes of translation and reception of theory. Said's analysis is not only sympathetic to the destination at which Williams arrives but is itself, I would argue, an example of cultural materialist analysis. Said's focus is what he sees as the homologous relation, in Lukacs, between class consciousness and 'theory'. Subject and object become an identity with the selfunderstanding of consciousness, inaugurating the perspective of totality beyond the perspective of reification: 'Consciousness goes beyond empirical givens and comprehends, without actually experiencing, history, totality, and society as a whole - precisely those unities that reification had both concealed and denied. At bottom, class consciousness is thought thinking its way through fragmentation to unity' (pp. 232-233). At this point, when classes become aware of themselves as historical potentialities (in other words, when they 'impute' themselves), 'Consciousness had moved from the world of objects into the world of theory' (p. 234), theory here being figured as projective, so that 'consciousness looks ahead to complete self-realization, which is of course the revolutionary process stretching forward in time, perceivable now only as theory or projection' (p. 234). Theory and Lukacsian class consciousness, in this formulation, are the same; classes, using information from their real experiences, theoretically impute themselves and move from this imputation to revolutionary activity, a process which Lukacs (in the preface to the 1967 edition of $H C C$ ) was later to criticize as anti-Leninist and utopian.

Said then moves on to Goldmann, arguing that the French Marxist's appropriation of Lukacs's thought depletes its insurrectionary potential and renders the 'totality', itself reduced to a signifier of the coherence of a particular 'world-view', a function of the hermeneutic activities of academics in the study of great writers. For Goldmann, 'the theoretical enterprise, an interpretative circle, is a demonstration of coherence: between part and whole, between world vision and texts in their smallest detail, between a determinate 
social reality and the writing of particularly gifted members of a social group ${ }^{58}$ (Said, 1983, p. 235). Said delivers the following judgment:

Goldmann's adaptation of Lukacs removes from theory its insurrectionary role. The sheer existence of class, or theoretical, consciousness for Lukacs is enough to suggest to him the projected overthrow of objective forms. For Goldmann an awareness of class or group consciousness is first of all a scholarly imperative, and then - in the works of highly privileged writers - the expression of a tragically limited social situation ... to put it another way, for Lukacs theory originates as a kind of irreducible dissonance between mind and object, whereas for Goldmann theory is the homological relationship that can be seen to exist between individual part and coherent whole. (1983, pp. 235-236)

The first thing to be said about this otherwise acute analysis is that it fails to distinguish between the consciousnesses of different classes, so that Said takes 'consciousness' in general to be, for Lukacs, a sufficient condition for revolution. For Lukacs, of course, only proletarian class consciousness is sufficient for proper awareness of the totality and thus revolution; the non-proletarian class consciousness of, say, the great bourgeois novelists, which is tragic insofar as the fate of their class is tragic (against the grain of history), would be no more the guarantor of revolution for Lukacs than it is for Goldmann. The more important point made by Said, in my view, is that Goldmann makes class consciousness (including proletarian class consciousness), by an intensification of its connection to 'theory' more broadly conceived, into something which is initiated (imputed) by the 'scientific researcher' (p. 234) in his/her dialectical analysis of great works of literature. This may then be profitably distinguished both from the Lukacs of 1923, for whom imputed proletarian class consciousness is a spontaneous outgrowth of the working-class itself, and from the Lukacs of 1967, for whom it is the 'imputed' product of professional revolutionaries on the Leninist model.

Said claims that the considerable difference between the two thinker's use of the same categories may be at least partially explained by the fact that 'Lukacs writes as a participant in a struggle (The Hungarian Soviet Republic of 1919), Goldmann as an expatriate historian at the Sorbonne' (1983, p. 236). While he can accept that 'Goldmann's adaptation of Lukacs degrades theory ... domesticates it somewhat to the exigencies of a doctoral dissertation in Paris' (p. 236), Said is also keen to emphasize that not all 'borrowings inevitably involve

\footnotetext{
58 The debt to Goldmann owed by Williams's (2009 [1977]) reading of imputed class consciousness as a more 'coherent' version of actual consciousness should be clear.
} 
misreadings' (p. 236), and even where misreadings occur they ought often to be judged 'as part of a historical transfer of ideas from one setting to another' (p. 236). He therefore concludes:

The Hungary of 1919 and post-World War II Paris are two quite different environments. To the degree that Lukacs and Goldmann are read carefully, then to that precise degree we can understand the critical change - in time and in place - that occurs between one writer and another, both of whom depend on theory to accomplish a particular job of intellectual work ... In measuring Lukacs and Goldmann against each other, then, we are also recognizing the extent to which theory is a response to a specific social and historical situation of which an intellectual occasion is a part. Thus what is insurrectionary consciousness in one instance becomes tragic vision in another, for reasons that are elucidated when the situations in Budapest and Paris determined the kinds of theories produced by Lukacs and Goldmann. (1983, p. 237)

In Said's elaboration of theory as a 'response' to a social situation we can hear echoes of Williams's analysis of art, and indeed of consciousness. One of the consequences of applying a 'response-theory' to intellectual output is that it implies, but does not necessitate, a certain relativism with regard to the capacity of theory to apprehend reality. One can imagine a 'theory of theory' based upon response to a specific situation which is not relativistic (arguably, Lukacs's own), but Said's argument, which emphasizes the cultural dimension of theory, moves tendentially in a relativistic direction. Moreover, Said's reluctance to fully distinguish between the consciousness of different classes leads him to a flawed conception of Lukacs's and Goldmann's incompatibility. Thus, when he states that 'what is insurrectionary consciousness in one instance becomes tragic vision in another, for reasons that are elucidated when the situations in Budapest and Paris are seriously compared' ( $p$. 237), I think it is necessary to both criticize the initial conflation ('insurrectionary consciousness' is, in Lukacs, proletarian class consciousness; the 'tragic vision' is that of the dying noblesse de robe) while retaining the useful emphasis on the element of politicogeographic transmission. Said is undoubtedly correct to argue that Budapest and Paris, with all their historical and political import, 'provide limits and apply pressures ${ }^{59}$ to which each writer, given his own gifts, predilections and interests, responds' (p. 237).

So too, then, with Williams, in his own time and place. I suggested earlier that Williams's conception of totality was as a potential form of critical practice aimed at resolving the abstractions and false

\footnotetext{
${ }^{59}$ This language is directly lifted from Williams's work on base and superstructure in the seventies, in particular 'Base and Superstructure in Marxist Cultural Theory' (2005c).
} 
dualities of the debates of the thirties (base vs superstructure, aesthetic values vs fallen industrial society etc) and replacing them with a holistic analysis of the 'whole social and material process'. Said pursues a different line of argument, suggesting that, in Williams's hands, 'Lukacs's thought - in this instance the avowedly revolutionary idea of totality - has been tamed somewhat. Without wishing in any way to belittle the importance of what Lukacs's ideas (via Goldmann) did for the moribund state of English studies in late twentieth-century Cambridge, I think it needs to be said that those ideas were originally formulated in order to do more than shake up a few professors of literature' (1983, p. 238). In some ways, this overstates the case, since in $H C C$ the totality is above all a statement of ontology, not strategy. At the same time, Lukacs's formulation of class consciousness in HCC does tend towards rendering the attainment of knowledge of the totality immanently revolutionary, since such knowledge is only achievable by the revolutionary proletariat (the tautological character of such a formulation is precisely what Lukacs was, in 1967 , to disavow).

What starts to become visible here is the tension between the influence on Williams of Lukacs on the one hand and of Goldmann on the other. Williams responds positively, I think, to the implication of the early Lukacs (which Lukacs later disavowed and for which he drew harsh criticism from his fellow Marxists) that the perspective of totality may be in some way the spontaneous outgrowth of the working-class, of their coming to be aware of a truth which, in traditional Marxist theory, could only be 'imputed' onto them by others. Such a reading is broadly attuned to Williams's own conception of the essential validity of the consciousness of ordinary people and the fidelity of their responses to experience; it is when the notion of 'imputed' consciousness is taken not as a hypothetical point of departure, but as a real-world process of 'imputing' thoughts and feelings into the working-class for the purposes of ideological motivation (which was, Lukacs later claimed, how he had always intended it), that Williams cannot hold to totality in its Lukacsian sense. However, at the same time as he can affirm the spontaneity and experiential responsiveness of immanent consciousness, Williams is also drawn to Goldmann's conception, described by Said, of the 'perspective of totality' as a form of critical intellectual activity geared to towards the theoretical revelation of the homology between part and whole, a practice which may well, in the final analysis, be reserved for an intellectual class. The combination of these influences produces an uneasy tension between the steadfast advocacy of 'actual' consciousness, the real, categorically indeterminate responses of ordinary people to their lives, and the role of what may always be an elite critical activity: rigorous (intellectual) analysis of the whole social and material process.

Despite flagging up the disjunction between insurrection and critical reflection, Said's sympathies appear to lie with the latter: 'because Williams is not the militant Lukacs, because Williams is a reflective critic - this is crucial - rather than a committed revolutionary, he can 
see the limits of a theory that begins as a liberating idea but can become a trap of its own' (1983, p. 238). Said approvingly quotes Williams from 'Literature and Sociology' to the effect that Lukacs does not always carry the insights of $H C C$ through to the most penetrating conclusions (a common refrain), and that Goldmann too is susceptible to "certain cruder operations - essentially still those of base and superstructure' (Williams, 2005f, p. 21). 'What looked like the methodological breakthrough', says Williams, 'might become, quite quickly, the methodological trap' (p. 21). Said's (1983) interpretation of these and other comments is as follows:

What he means, I think, is that once an idea gains currency because it is clearly effective and powerful, there is every likelihood that during its peregrinations it will be reduced, codified, and institutionalized. Lukacs's remarkably complex exposition of the phenomenon of reification indeed did turn into a simple reflection theory; to a degree of course, and Williams is too decently elegiac to say it about a recently dead old friend, it did become this sort of idea in Goldmann's hands. (1983, p. 239)

For Said, Lukacs follows the logic of his own categories too closely, verging on dogmatic repetition and self-parody: '[Lukacs's theory] risks becoming a theoretical overstatement, a theoretical parody of the situation it was formulated to remedy or overcome' (p. 239). Reification is too absolute a domination by capitalism over social life, totality too absolute a theoretico-revolutionary solution, the result being a categorical polarity which is blind to the uneven porosity of power and discourse: 'For all the brilliance of his account of reification, for all the care he takes with it, Lukacs is unable to see how even under capitalism reification itself cannot be totally dominant' (p. 240). This in particular is very much in keeping with Williams's conception of an ever-changing mixture of residual, dominant and emergent factors (as opposed to the utter hegemony of the dominant factor which one version of reification implies). 'If you want to be told that our whole existence is governed by the economy' Williams notes wryly in Politics and Letters, 'go to the city pages of the bourgeois press - that is really how they see life' $(2015$, p. 141); just as the notion of art as superstructure engendered, for Williams, a malign (because divisive of the totality) ideological effect, so too is the notion of an omnipotent reification tantamount to political reaction.

Ultimately, then, Said conceives of Williams's appropriation of Lukacs as one of useful transformation rather than evolution or improvement. 'There is an extraordinary virtue to the distance,' says Said, 'even the coldness of his critical reflections of Lukacs and Goldmann, to 
both of whom he is otherwise so intellectually cordial' (1983, p. 240). Said argues that Williams's late work, and in particular the essay 'Base and Superstructure in Marxist Cultural Theory' (1973), acknowledges that 'the terminology provided by Marxist aesthetic theory for mapping the peculiarly uneven and complicated field lying between base and superstructure is generally inadequate, and then Williams goes on to do work that embodies his critical version of the original theory' (p. 240). A 'critical version of the original theory' is, I think, a good way to describe what Williams produced as a result of his exposure to Goldmann and Lukacs, provided that we conceive of the 'original theory' somewhat narrowly, as the conflict between reification and totality. In his concluding remarks on Williams, Said emphasizes the constitutive role played in Williams's work by 'travelling theory' and elucidates a general meta-position on theory which owes a lot to Williams, and which reflects the growing influence, in the eighties, of post-structuralist and post-Marxist perspectives:

There is no minimising the fact that Williams is an important critic because of his gifts and his insights. But I am convinced it would be wrong to underestimate the role in his mature writings played by what I have been alluding to as borrowed, or travelling, theory. For borrow we certainly must if we are to elude the constraints of our immediate intellectual environment. Theory we certainly need, for all sorts of reasons that would be too tedious to rehearse here. What we also need over and above theory, however, is the critical recognition that there is no theory capable of covering, closing off, predicting all the situations in which it might be useful. This is another way of saying, as Williams does, that no social or intellectual system can be so dominant as to be unlimited in its strength. Williams therefore has the critical recognition, and uses it consciously to qualify, shape and refine his borrowings from Lukacs and Goldmann, although we should hasten to add that it does not make him infallible or any less liable to exaggeration or error for having it. (1983, p. 241)

While I do not think Said is correct to apportion to Williams a greater degree of critical 'recognition' or 'reflection' than Lukacs or Goldmann simply by virtue of his status as an academic, in a non-revolutionary situation, introducing a stronger note of caution into their theories (politics, after all, need not be less critical than criticism, nor criticism less political than politics), he is absolutely right to position Williams on the side which refuses to see reification as all-pervasive (a viewpoint which has considerable and immediate implications for socialist strategy). Said is also correct to characterize Williams's thought as being profoundly affected by travelling theory, and the two dimensions which Said's essays brings out (the dissatisfaction with any totalizing definition of capitalism/reification and the influence of European theoretical impulses), are dialectically bound. The discussions contained in Politics and Letters (1979) and the sentiments expressed in Williams's later 
reviews make the interaction between the 'travelling' influences and Williams's own theory especially clear. Williams is using the work of Lukacs and Goldmann to remedy what Anderson described as 'the lack of either a classical sociology or a national Marxism' in Britain; at the same time, what those very lacking elements mean is being tested and transformed by contact with Williams and his own very different intellectual inheritance.

At a crucial point in PL, Williams's New Left Review interlocutors raise the question of the primacy of economic production in historical processes, generally taken to be a hallmark of historical materialism, and ask Williams for his viewpoint. There follows a discussion in which Williams charts the development of his thinking on this issue between The Long Revolution and Marxism and Literature. In The Long Revolution, he had described the social totality as comprising four essential systems interacting on the basis of 'parity of structure' (2015 [1979], p. 138); these were the system of 'maintenance' (economic), the system of 'decision' (political), the system of 'communication' (cultural), and the system of 'generation and nurture' (familial). The intervening period taught Williams two things which forced him to make significant alterations to the idea of structural parity between systems: first, that 'the relative importance of different kinds of production and social processes can be very uneven' 2015 , p. 138) and secondly that there is always 'a temporal unevenness in the formation and evolution of these structures' (p. 138). In light of these lessons, says Williams, 'My present vocabulary of dominant, residual and emergent patterns within any given culture is intended to indicate precisely the phenomenon of this historical discrepancy. So in these respects there has been a quite decisive change in my thinking' (p. 138). Acceptance of the notion of structural unevenness permits the conceptualization of the relative dominance of a single system, and it is in precisely this developmental context that Williams encounters Lukacs and is energized, if not entirely convinced, by the idea of reification (in Williams's use, the dominance of the economic order):

Today, however, I am interested in the increasing influence of the idea, which derives originally from Lukacs, that the domination of the economic order of society is peculiar to the capitalist epoch. I find that difficult to accept in its simplest sense, but it would explain one's sense of a qualitative alteration of the meaning of production precisely as the capitalist mode of production itself matured. It is at any rate noticeable that in the 20th century the exponents of capitalism have been the most insistent theorists of the causal primacy of economic production. (2015 [1979], p. 141) 
Williams's charge against the apologists of capitalism, that they regard economic production as determining the rest of social life (and approve of this), raises the question of whether this charge should also be leveled against Lukacs, to whom Williams attributes a similar perspective. It is necessary here, I think, to distinguish sharply between 'domination' and structural primacy. Reification, as formulated by Lukacs or by Williams (they each formulate it somewhat differently), is undoubtedly a vehicle for domination, whether of the ideological interests of the bourgeoisie over the proletariat (Lukacs) or of economic (commercial) values over values of community and solidarity (Williams); whether or not a particular element in the totality of social life is dominant over another is, however, a different question, since in theory an element may be afforded structural primacy without exerting 'domination' in the normative and moral senses relevant to Williams's political argument. Williams's suggestion that the dominance of the economic order is in principle politically regressive therefore charts a theoretical trajectory at odds both with the organs of business and financial propaganda, for whom the domination of social life by market imperatives is both true and felicitous, and with the mainstream of Marxist theory, for whom the same domination is true, but undesirable because of its specific character under capitalism (namely, the reduction of human beings to chattel for the production of surplus-value).

The above theoretical distinctions have direct and serious implications for the relationship between socialist strategy and literary and cultural criticism, since they unavoidably broach the question of how 'domination' under capitalism is, can or should be represented. Recall that, for Lukacs, reification produces false consciousness because, by fragmenting social life and ossifying available appearances, it prevents human experience from perceiving that social life is determined by economic activity, specifically the reality of generalised commodity production (and thereby exploitation) under capitalism. For Williams, on the other hand, reification indicates a 'false objectivity', by which he means that it produces an erroneous sense of the domination of capitalist economic activity (however defined) when, in reality, the totality of social life is heterogeneous and contested. In both formulations, capitalism itself produces reification (on this Lukacs and Williams are agreed), but then the question of whether or not to portray social life as being primarily structured by capitalist imperatives (and how do so) must be answered very differently depending on which position is affirmed. From the Lukacsian perspective, economic activity should be portrayed as having a determining effect, and reification revealed as deeply pervasive, precisely in order to portray the totality (the question then is how to achieve this at the technical and formal level). From 
Williams's perspective, to portray social life as being overwhelmingly determined by capitalist imperatives would, conversely, be to deny the totality as it really exists (as a shifting lattice of dominant, residual and emergent strands). Such a viewpoint does not deny the necessity of demonstrating the power and influence of reification conceived of as the domination of commercial values, or indeed of demonstrating the extreme prevalence of economic exploitation under capitalism, but it is nevertheless a conception of the role of literary realism which diverges sharply from Lukacs's.

The divergence described above is significant given that Williams's early views on realism, particularly as expressed in The Long Revolution, ${ }^{60}$ have been at the centre of comparisons of him with Lukacs. There Williams praised what he calls the 'realist tradition' (Williams, 2013, p. 321) in the novel, defined as that ...

... which creates and judges the quality of a whole way of life in terms of the qualities of persons ... Neither element, neither the society nor the individual, is there as a priority. The society is not a background against which the personal relationships are studied, nor are the individuals merely illustrations of the way of life. Every aspect of personal life is radically affected by the quality of the general life, yet the general life is seen as its most important in completely personal terms. We attend with our whole senses to every aspect of the general life, yet the centre of value is always in the individual human person. (2013 [1961], p. 322)

In effect, Williams endorses a dialectical view of the relation between the individual and society (each is mutually constitutive of the other), and determines that realist fiction is preferable to those modes in which the portrayal either over-subjectifies or over-objectifies reality. Realist fiction, formulated as bearing a relative proximity to reality, is precisely that fiction which avoids the 'polarisation of styles, object-realist [documentary] and subjectimpressionist' (p. 323), in terms of the vacillation between which 'it may indeed be possible to write the history of the modern novel' (p. 323). Williams criticizes recent developments in the novel for failing to perceive the deep interrelation of all individuals and the societies of which they are a part. The 'personal novel', for example, 'as it is now developing ... ends by denying the majority of persons. The reality of society is excluded, and this leads, inevitably, in the end, to the exclusion of all but a very few individual people' (p. 329). The 'social

\footnotetext{
${ }^{60}$ It should be noted that Williams's position on literary realism, while retaining some underlying assumptions, develops new emphases over time. In The Long Revolution (1961), realism is the portrayal of a dialectical relation between the individual and society; in later writings realism is attached to the politics of place and the 'knowable community' (ENDL, 1970a), and later still to a kind of intentional critique mixed with other features ('A Lecture on Realism/A Defence of Realism' (1977)).
} 
novel', all too often, does the opposite. The shared negative property, as so often for Williams, is the fragmentation of what is here described as realist 'balance' (p. 326), later as the literary-critical component of the perspective of totality.

Williams's analysis clearly makes the assertion that there are more and less accurate ways of perceiving and portraying social reality. 'There are perhaps a thousand cases', Williams suggests, 'where the restriction [of the polarizing new styles] is simply a failure of consciousness, a failure to realize the extent to which the substance of a general way of life actively affects the closest personal experience' (2013, p. 326). This comes very close, of course, to a traditional Marxist analysis along the lines of 'false consciousness', and indeed the implication throughout is that non-realist fiction is guilty of a failure of perception. But then what accounts for this failure and what, if anything, is its remedy? To the question of the origins of the 'crisis' (p. 330), Williams offers the following preamble to an answer:

The realist novel needs, obviously, a genuine community: a community of persons linked not merely by one kind of relationship - work or friendship or family - but many, interlocking kinds. It is obviously difficult, in the twentieth century, to find a community of this sort. (2013 [1961], p. 330)

A 'genuine community' of persons, then, is necessary for the health of the realist novel, at least as we have known it. Williams notes the passage from the typical Victorian narrative, which ends with 'a series of settlements, of new engagements and formal relationships' ( $p$. $33)$, to the modern, which 'ends with a man going away on his own, having extricated himself from a dominating situation, and found himself in so doing' (p. 331). The modern novel, then, reflects the real breakup of established communities and human relationships in the modern period; the movement towards personal assertion (and the concomitant distancing the individual from society) is a necessary process, says Williams, even if it appears to derail the realist project: 'while old establishments linger, and new establishments of a dominating kind are continually instituted, the breakaway has continually to be made, the personal assertion given form and substance, even to the point where it threatens to become the whole content of our literature' (p. 331). In this sentence are included all the elements of Williams's later formulation of residual ('old establishments'), dominant ('new establishments of a dominating kind') and emergent ('the breakaway') elements. Williams's analysis, for all its critical edge, suggests that the social conditions which have given rise to the modernist narrative, with its significant fragmentation of the realist dialectic, are not symptoms of 
Lukacsian decadence but rather an appropriate response, as individuals grapple, fallibly and partially, with the impact of accelerated historical change on the social totality. Relative to Lukacs, of course, what is missing from Williams's early critique of modernism is any mention whatsoever of class.

The gulf between Williams and Lukacs on the question of how non-realist fiction relates to totality and the 'phases of a class' (Williams, 2015, p. 221) is a recurring theme of the literary discussions in Politics and Letters. During a broader conversation centered on drama, Williams's $N L R$ interlocutors challenge him to react to Lukacs's critique of naturalism. Referring back to Williams's formulations in TLR, NLR sets out the Lukacsian stall as follows:

Realism, which Lukacs defined in very similar terms to your own as a kind of synthesis of the personal and the social, is in effect the great aesthetic achievement of the bourgeoisie, when it is still in its historical ascent. Naturalism is the decadent successor to it, which has ruptured the dynamic linkage between men and women and their society, indeed projects society into a kind of second nature ... Characters in naturalist fiction become essentially passive ... Lukacs argues that naturalism sets in as the bourgeoisie ceases to play a progressive historical role in $19^{\text {th }}$ century Europe ... Here the opposition between naturalism and realism is founded historically and corresponds to the variant social destiny of a class. (2015 [1979], p. 220)

Anchoring the discussion in Williams's critique of dramatic naturalism in Drama from Ibsen to Brecht, the questioners note the similarity between Lukacs's position and Williams's complaint that naturalist fiction undialectically portrays 'the external determination of the characters in the drama by forces that remain permanently beyond them' (p. 220). They note that in Williams's analysis even 'Brecht retained the central knot of the naturalist structure of feeling, for the two terms of his drama remained the unmodified pair of the isolated individual and the overwhelming society ranged against the individual' (p.214). What is lacking is the element of mediation between the individual and society (in Marxist terms, class), the inclusion of which in the narrative or action would render the relation between the two poles explicable and 'realist', freeing the characters from simple passivity in the face of an alien objectivity. Lukacs's account, $N L R$ suggests, 'appears compatible with your own account in that you lay great stress on the fact that naturalist theatre, even at its height, is unable to re-create or embody a dynamic interrelationship of persons and societies: the greatest masters of naturalism do not achieve that, whereas the masters of the realist novel did' (p. 220). 
Williams is asked whether he concurs with $N L R$ 's reading, and whether drama is capable of reaching beyond the constraints of naturalism towards a more realist portrayal of the relation between the individual and society. His response highlights the difficult absorption by Williams of two quite different conceptions of realism derived from either side of Lukacs's conversion to Marxism: a) realism as social critique via the portrayal of a thwarted subject beset by hostile objective conditions (The Theory of the Novel) and b) realism as the accurate (historical materialist) portrayal of the dialectical interrelation of subject and object in the totality. 'Naturalist drama', argues Williams, 'in spite of the limitations we have discussed, still seems to me to be committed to what Lukacs elsewhere describes as the classical realist project: showing a man or woman making an effort to live a much fuller life and encountering the objective limits of a particular social order ... the structural constraints of a society' (2015, p. 221). This progressive naturalism, which Williams associates with Ibsen and Strindberg, 'proclaimed that social life was stifling, and affirmed the validity of suppressed desires and impulses to a point where it questioned the whole order, though by definition the work did not get through to breaking with it' (p. 222). Thus Williams argues that naturalism of this sort, while falling well short of revolutionary aspirations, was still, like the work of the classical realists, capable of playing a progressive social role. Williams's opposition to Lukacs's specific critique of naturalism as the product of a decadent bourgeoisie thus proceeds on two fronts: firstly, he disputes Lukacs's claim that bourgeois art in general is, after a certain historical juncture, incapable of progressivity; secondly, as we have seen, he disputes the notion that developments in art may be explained solely by the phases of the class producing them. Naturalist writers were 'all bourgeois in their social composition' (p. 222), but the progressivity of their texts belies the notion that their class had entered a stage of accelerated historical degradation. 'Perhaps it would be simpler', Williams suggests, 'if we called it realist drama' (p. 222).

$N L R$ correctly point out that 'The action of a man or woman who seeks a freer life with a greater attainment of value in it and finds the society an insuperable barrier ... is not what Lukacs called the realist project. It is rather the leit-motif of Theory of the Novel, before he was a Marxist critic at all' (2015 [1979], p. 222). Williams does not explicitly answer the charge; both interpretations of the realist project, it seems, continue to inform Williams's reception of Lukacs and, in complex ways, his own practice. It would be unfair, however, to imply that Williams is ignorant of the contradiction between reifying portrayals which paint 
society as the dominant agent in the pair individual/society, and those in which the pair are represented as mutually constitutive. When Williams states, for example, that 'Lukacs's characterisation of $\ldots$ the realist novel in the $19^{\text {th }}$ century as the discovery by the dramatic hero of the limits of an unjust society ... is based much more largely on French and some Russian fiction than on the European novel as a whole' (p. 349), he is attempting to distance the European novel from the former conception. Williams broadly rejects Lukacs's preMarxist formulation of the realist project, but then cannot fully endorse the later Lukacs's more dialectical view either, since it relies on the notion of a 'pre-existent' social reality constructed upon, and rigorously determined by, inter- and infra-class structures. 'My argument for realism has always been', Williams insists, rounding out the discussion in $P L$, 'that it is a certain perception of reality and a certain awareness of interrelationships, not that it carries a certain mode of composition within it, nor that it has a second-order relation to a pre-existing reality' (p. 350).

\section{A Man without Frustration}

I began this chapter with a quotation from Williams's 1984 review of the autobiographical Georg Lukacs: Record of a Life, in which Williams restated his distance from Lukacs on questions of art, and called for an end to the era of 'high intellectuals, with their own curriculum and preoccupations' (1984a, p. 15), bringing their theories to bear on the 'real life' of culture and politics. Williams advocated the reversal of this process, a return to everyday life as 'a hard and contested starting point' (p. 15). In concluding the present chapter I now briefly return to this review and others that Williams wrote towards the end of his career. All are reviews of texts published in English after Lukacs's death; in them, we see Williams pursuing the difficult object of finally assessing Lukacs's effect on himself and, more generally, on socialist discourse and literary criticism.

In 1977, Goldmann's ambitious philosophical work Lukacs and Heidegger: Towards a New Philosophy (French: 1973) was made available in English; Williams reviewed it in New Society the following January. The review ranges widely, touching on many of the themes we have already discussed, including the tension between actual and imputed consciousness and the relation between class and literary form. Williams introduces readers of New Society to Goldmann's 'genetic structuralism', a non-positivist approach to sociology based on 'the analysis of forms, which disclose the true general situation of the group in its relations with 
other groups' (1978a, p. 26). In this view, classes are culturally manifested as 'collective subjects' who 'originate all cultural creation, through characteristic forms' (p. 26). It is in the raw objective data obtainable from these forms, rather than in the information 'ordinarily available to empirical enquiry' (p. 26) that, for Goldmann, genuine social knowledge may be found. From this stems the literary-critical goal of seeking out 'those major works in which a "potential consciousness" is most coherently and completely articulated' (p. 26). While such an approach tends in the synthetic direction Williams advocated for realism, he reproaches it for risking an 'implicit classicism' (p. 26) and for neglecting those elements of discontinuity and ideological tension in works as canonical as King Lear. Here we find a stronger critique of the 'coherence' model of consciousness which Williams had earlier found useful in Lukacs (as Williams understood him). He reserves his critical ire, however, for what he sees as the necessary political outcomes of such a viewpoint.

An interesting aspect of Goldmann's text is its discussion of Lukacsian actual and imputed consciousness alongside the existentialist binary 'authentic'/'inauthentic' as expressed by Heidegger (and, of course, Sartre). Williams is deeply suspicious of the implications of equating the two binaries, wherein actual consciousness, the product of ideological distortion, is equated with the 'inauthentic' and imputed consciousness with the 'authentic'. Whether or not actual consciousness is inauthentic is, for Williams, a matter for precise historical investigation, particularly when it comes to the analysis of the class character of literary works, and is a question ill-suited to the pursuit of totalizing theories: 'The distinction between "ascribed" and "inauthentic" works is, however, the outcome of the difficulties of specific groups in specific historical periods. It is easy to see the attraction of a concept of "ascribed consciousness" to intellectuals already seized by a global (Hegelian or Marxist) view of history and of classes' (1978a, p. 26). The implication of 'already seized' here is that literary intellectuals are bringing their pre-conceived social and political theories to the work of analyzing specific texts. The two 'magisteria', literature and politics, are inextricably linked, but the critical procedures which best acknowledge this seem wed to a familiar elitism. In expressing this point, Williams makes a brief but suggestive foray into the language of psychoanalysis:

...the relation of intellectuals (critical and revolutionary intellectuals) to "the masses" is implicit in the theoretical starting-point. A class generates only "actual consciousness"; "ascribed" or "potential" consciousness has to be theoretically, 
culturally or politically created. Thus within the "collective subjects" there is an effective split, between "conscious" and "unconscious" creators. (1978, p. 27)

Here the ascription of 'unconsciousness', meant not as 'false consciousness' but as 'acting without consciousness', is employed by Williams to critique the elitist assumptions both of Leninist/Lukacsian politics, and the literary-critical practice of both Lukacs and Goldmann. In assessing Said's 'Travelling Theory', I noted that, for the Williams of 'Literature and Sociology', there was a tension between his rejection of Lukacs's neo-Leninist elitism and his appreciation for Goldmann's conception of the 'perspective of the totality' as a form of critical intellectual practice. Though the distinction is retained in the later Goldmann review, the tension is somewhat elided as both positions now receive robust critique: the 'division between "actual consciousness" (that of the majority) and "ascribed" or "potential" consciousness (possessed, articulated or initiated by minorities) led in one period to Stalinism; leads now to the ratified privilege of "revolutionary" intellectuals' (p. 27).

Williams closes the 1978 review in an impatient tone which increasingly shows itself in his later writing about Lukacs: "The problems of "ascribed" consciousness are little more than a phase in the history of ideas; beyond that they can be forgotten' (1978a, p. 27). Nowhere is this harsher critical edge employed to more biting effect than in Williams's 1980 review of Essays on Realism, a long-delayed English publication of some of Lukacs's seminal literarycritical essays of the thirties. It is in these essays, some of them republications of polemical articles in newspapers and journals in which Lukacs is interacting directly with other commentators and writers on the issue of realism, that Williams finds Lukacs most arrogant and abrasive. The key examples of this, for Williams, are Lukacs's responses to the proletarian fiction of Ernst Ottwalt and Willi Bredel, in which Lukacs castigates both writers for insufficiently portraying the fundamental class-based character of the social totality:

It has to be said, first, that Lukacs's tone in these essays is appalling. It is as if he cannot avoid being patronizing, and in one way he deserved what he got when Bredel's novel and Lukacs's article were shown to (we don't know how many and how selected) German workers and got the response: "the book is good, the other stuff is shit." I have felt the same way reading the British working class novelists of the thirties and some of the academic and critical writing about them: a contrast between the struggling and imperfect producer and the high-class-consumer theoretician and critic. (New Society, 1980, Nov 20, p. 381) 
If, during the sixties, Williams had held out some hope that Lukacs's ideas might represent a solution to the literary-critical contradictions of the thirties, the above quotation provides perhaps Williams's clearest acknowledgment that by the late seventies and early eighties he regarded such hopes as having been very seriously misplaced. Lukacs's tendential elitism, his inability to accept the fundamental validity of diverse, even imperfect forms of consciousness remains, for Williams, in insuperable barrier to his efforts to establish a normative theory of literary realism. And yet it remains impossible to discard the questions which Lukacs's work raises. Still to be overcome, and in this Williams deviates little from his position in The Long Revolution, is the problem of 'representing working class life and at the same time introducing the necessarily different consciousness of the objective conditions and wider historical movement within which the men and women live and act' (p. 382). Williams sees Lukacs as having manifestly failed to solve this problem, but nevertheless 'the insistence that the problem exists is valuable' (p. 382). He concludes that 'the problem of finding ways of interlocking substance and system remains central and challenging, and it is not helpful to collapse in towards either of its poles', and that 'it is in just this effort to interlock, in convincing composition, that the whole realist project is defined, and Lukacs, who more than anyone showed us this, in fact damaged the project by tying it so closely to "traditional methods"' (p. 382).

The desire to assess and pin down Lukacs's legacy was a common goal of several Marxist writers in the early eighties. Williams reviews three such efforts during the period: Georg Lukacs: From Romanticism to Bolshevism by Michael Lowy (1979), Lukacs Revalued, a collection of essays edited by Agnes Heller (1983) and The Young Lukacs by Lee Congdon (1983). The latter two are mentioned only fleetingly in the body of the larger review of Lukacs's autobiography in 1984, but Lowy's text, reviewed by Williams in 1980, receives a longer treatment. Perhaps the most interesting thing about the review is how little Lukacs features in it. Williams focuses for the most part on what he sees as Lowy's great achievement: mapping out the pre-1914 central European intellectual milieu out of which Lukacs's Bolshevism is said to have developed (breaking with that tradition in the process). Williams identifies with the situation of 'that brilliant, mainly German, generation, between the 1880s and 1914,61 (New Society, 1980b) whose 'diffuse anti-capitalism' (1980b) enjoined them to engage in a series of difficult problematics which Williams sees as strikingly relevant

\footnotetext{
${ }^{61}$ There is some overlap between this group and the tradition H. Stuart Hughes discusses in Consciousness and Society (1958), whom Anderson (1966) suggested were the idealist precursors of the Western Marxists.
} 
to his own period: 'The hard intellectual and political choices, including quite radical divergences, which under pressure emerged from what had seemed a reasonably common position, have a very close, moving and challenging, relevance to our own strictly contemporary situation' (1980b). Lowy sees the substance of those 'hard choices' as being dramatized in Lukacs's transition, which he endorses, from romanticism (here used synonymously with 'diffuse anti-capitalism') to Bolshevism. Williams cannot accept this characterisation of the difficult situation in which the pre-1914 anti-capitalists found themselves, nor the interpretation of Lukacs's development which it argues for; his nuanced critique of Lowy's argument is worth citing here in full:

Of course one major way out of that substantial but diffuse anti-capitalism was the theory and practice of Bolshevism. But today, at a certain imposed distance, the problems of that road, and some of its major points of arrival, are too evident to allow us to dismiss the preceding positions as, where they are useful at all, merely preparatory. If the diffuse anti-capitalism of those days spent so much time analyzing the problems of state bureaucracy, of the relations between a modern industrial system and quantitative kinds of thinking and administration, of the difference between actual communities and a centralized monetary social order, we can hardly, from the late seventies, suppose that they were wasting their time or missing some simple central truth. Bolshevism, in this perspective, looks less like a solution than a short-cut to both new possibilities and some of the same old problems. (New Society, 1980b)

What is crucial in this analysis is the attention Williams pays to Lowy's pseudo-Hegelian sense of temporality. For Lowy, Bolshevism represents the 'sublation' of the contradictions inherent in the problematics faced by the pre 1914 European anti-capitalists. From this perspective, their diffuse anti-capitalism appears as preparatory, a necessary stage in the development of consciousness towards its appropriate historical form; Lukacs, for all the imperfections and inconsistencies in his development, becomes a kind of metaphor for this necessary movement. For Williams, on the other hand, the contradictions faced by the pre1914 group, much like those expressed in the debates between Marxists and Leavisites in the thirties, have stubbornly refused to resolve. These were, and remain, real problems to be faced down by socialists, not avoided or their emphasis by critical intellectuals disparaged on the grounds of 'romantic anti-capitalism'. Williams sees Lowy's tendency to describe nonMarxist-Leninist anti-capitalist positions as romantic as 'a muddle and at times a deliberate confusion between the historical reference - "Romantic" - and the deprecatory sense of "unrealistic", "cloudy", "impractical". And this is at every level intolerable, especially since its main intellectual result is to exclude those questions which were being put to the idea of 
socialism, from a number of positions within that complex earlier tradition' (1980b). The cost of this exclusion could hardly be higher; it 'has now to be diagnosed', argues Williams, 'as one major cause of damage to the theory and practice of socialism itself' (1980b).

One thing which made Lukacs an attractive figure to Williams was the way in which he appeared to straddle the divide between incorporation and outright rejection of the pre- and proto-socialist tradition out of which he had emerged. On the one hand, says Williams, Lukacs had to 'push away these earlier positions, in his relatively rapid transition to communism and above all in his later accommodation with Stalinism, during which most of the dismissive formulations were developed ${ }^{, 62}$ (New Society, 1980b). On the other hand, argues Williams, summarizing Lukacs's development:

The irony is that in History and Class Consciousness he recovered for Marxism, in part by returning to neglected elements in Marx, in part from the strongest elements in the anti-capitalist problematic, a dimension of social thought which in combination with a new revolutionary politics was indeed a major advance. In particular in his analysis of 'reification' he found ways of restating the critique of quantitative and instrumental consciousness and social relations in terms which genuinely connected with the struggle for socialism. But it is then a further irony, not only that he had to appear to withdraw from these new positions, under the pressure of actual developments which as a matter of fact were making them even more relevant, but also that when they came through again, in the crisis after Stalin, they were soon being attacked in the terms he had forged: as romantic idealism, and in the new rhetoric of abuse, as humanist and moralist. (New Society, 1980b)

When Williams writes in praise of 'a dimension of social thought in combination with a new revolutionary politics', he is referring, I think, to something like cultural revolution: an awareness of and a critique of reification, itself born of the breakdown of traditional communities, combined with the revolutionary determination to transform society by reclaiming the holistic and communitarian values Williams associates with the "perspective of totality'. Lukacs was the first Marxist writer to engage seriously with the breakdown of popular holistic modes of thought and to analyze them in terms of a 'failure of consciousnesses' (as Williams put it in TLR) brought about by concrete changes in the way people were experiencing their reality. The fact that Lukacs was forced to rescind some of the useful emphases of his earlier work, coupled with the backlash against that work in later years, is regarded by Williams as something quite tragic. Lukacs was wrong, finally, about class consciousness and realism, but he is nevertheless 'abused' by those later strands of

${ }^{62}$ Williams is probably thinking of the recently translated Essays on Realism (1983) here. 
Marxist thought which regard his early work as an aberration (partly for its connection to the work of the pre-1914 European anti-capitalists) and his more orthodox phase as the resolution of contradictions which have not, in fact, been resolved.

After having written very little about Lukacs's personal life and character, Williams's 1984 review of Record of a Life attempts to bring the real, historical Lukacs into focus as an alternative way of getting at the crux of his work. In part, this is a necessity owing to the material of the review: Lukacs's autobiography, an edited transcription of death-bed conversations with his friend Istvan Eorsi, and the two synoptic critical works from Heller and Congdon. But the two men had much in common, and it seems impossible, reading Williams's account of Lukacs 'the man', to avoid the conclusion that, even if equivalences were finally rejected, a comparison was being made. In concluding this chapter, I wish to briefly explore the resonances of that always implicit personal comparison.

The question of whether or not there is something of intellectual value to be gleaned from the transcribed utterances of Record of a Life, Williams (1984a) argues, is to a great extent determined by 'the kind of mind that is being questioned or interrogated' (1984a, p. 14). Williams is concerned first of all to deny the validity of two possible portraits of that mind, one from Lukacs himself, the other a speculative construction which Williams quickly disregards. From Lukacs himself, on this occasion originating in a separate NLR interview (1971), comes the image of a 'man without frustration':

I can say that I have never felt frustration or any kind of complex in my life. I know what these mean, of course, from the literature of the twentieth century, and from having read Freud. But I have not experienced them myself. When I have seen mistakes or false directions in my life, I have always been willing to admit them - it has cost me nothing to do so - and then turn to something else. $(1971$, p. 58)

Williams elaborates on Lukacs's self-description as the image of a man 'wholly dedicated to pure thought, who can indeed abandon and move on from positions and affiliations, without significant disturbance, and who moreover from that practice moves without difficulty into the kind of hard confidence, which can be interpreted as arrogance' (1984a, p. 14). Such a man, says Williams, were he to really exist, would be 'one kind of high intellectual, who knows and accepts and keeps his distance from what others see as substantial everyday life, and who can in fact rely on being judged, eventually, solely by the quality of his work' ( $\mathrm{p}$. 14). To be judged solely by the quality of one's work; this is not an aspiration which 
Williams feels it is possible to ascribe to Lukacs, the committed revolutionary socialist, to whom political action and effect must have been just as much the measure of success. But at the same time, and here enters the straw-man speculation, it is no more possible to put everything down to psychology, to explain the twists and turns of Lukacs's allegiances and positions to mere changes of heart: 'there is simply not enough evidence to move in one now familiar Western way, towards a form of psychological reconstruction and explanation' (p. 14). Williams is thus caught between two impossible portraits, of Lukacs as an arrogant and aloof pragmatist, constantly true to his own 'removed' thinking but able to move through disparate and incompatible commitments without psychological harm, and a totally speculative Lukacs, bearing no resemblance to reality, ruled, in one clichéd model, by his desires and passions, allowing his thinking to flow freely along affective channels.

To be 'a man without frustration', Williams seems to be suggesting, would above all mean possessing immense intellectual confidence, keeping one's work rigorously compartmentalized by 'delineating a sphere of public intellectual life from which merely personal matters are excluded' (1984a, p. 14). Before addressing the Lukacs which Williams arrives at in the course of dispelling the myth of the 'man without frustration', we might note that the issue of intellectual confidence and its relation to affect touches directly upon a recent episode in Williams's own life. As Fred Inglis (1995) recounts in his early biography of Williams, the interviews conducted in 1977-78 for what would become Politics and Letters took a heavy psychological toll on Williams. While Inglis is perhaps exaggerating when he describes Williams's subsequent state of mind as having 'approached a psychosis' (1995, p. 260), Williams's moving letter to Perry Anderson in 1979 indicates a profound anxiety and quite crippling depression:

The usual words don't help, but for what they're worth it's a condition of almost overwhelming anxiety, perpetually preoccupied - not only as a working habit but now as an almost paralyzing state - with qualification and revision and redefinition and exactness and so on, and the relations between that and the actualities and modes of past and present have come through as profound distress ... you'll remember Manod and my (prophetic) reply about that inexplicable kind of sadness, which I was then talking about mainly in others ... I've even known, for the first time, some of the states out of which defeatist and reactionary ideologies have been so often built ... But I'm fighting, and every handhold - what may seem to anyone else a marginal detail - has become crucial. (Williams quoted in Inglis, 1995, p. 261) 
In parts of Politics and Letters, Williams had indeed been very strongly and insistently challenged on the core assumptions of his thought. His Marxism, which had by now been named as 'cultural materialism', was rigorously critiqued, as were his long-held positions on literary realism. It is extremely difficult, reading through Politics and Letters, to speculate on which particular exchanges, upon later introspection, pushed Williams onto unstable ground. It seems likely, however, that $N L R$ 's sustained critique of formulations upon which it is no exaggeration to say that his life's work depended, played a central role. The primary symptom was an intense obsession with 'qualification and revision and redefinition and exactness'. Williams's writings had always been precise and tentative, even punctilious, but now the desire for authorial control, and to avoid misinterpretation, became paramount. It is notable that this painful episode in Williams's career occurred the year before the review of Lowy's book and only a few years before Williams was considering Lukacs, in one guise, as the 'man without frustration'; such a construction could hardly have been further from Williams's own recent intellectual and emotional trajectory. Williams engages in robust selfcriticism in Politics and Letters, and is generally open to the criticisms leveled at him by his interlocutors, but if he was at all convinced, internally, that he had gone in some wrong directions, he was not immediately able to crystallize those lessons into a detached 'hard confidence'. Williams wrote that the 'man without frustration', the aloof and confident intellectual, would feel satisfied that he would ultimately be judged 'by the quality of his work'; in 1979, this seemed to be precisely what Williams feared the most, developing an acute obsession with ensuring that posterity understood what he had been trying to say.

It is perhaps no surprise, then, that in 1984 Williams was not prepared to allow Lukacs his self-construction. Williams recounts some of Lukacs's utterances on his romantic entanglements, first with Irma Seidler, who committed suicide in 1911, then with Gertrud Bortsteiber, who was more politically and intellectually influential. The crucial point, for Williams, is that Lukacs regarded his personal development, including basic life decisions and romantic entanglements, as the mutually constitutive obverse of his political commitments and endeavors. As Lukacs puts it in Record of a Life:

What was at stake was my need to fuse my intellectual and practical aspirations with the contemporary world situation in such a way as to make my efforts bear fruit (not just objectively and practically right, but also favourable to my personal development) ... No one - with the exception of Lenin (in quite a definite sense) - has understood that the two processes are ultimately identical: that is, the social development of the 
new man is in effect a synthesis of the individual aspirations to come to terms with the novel reality in an honest revolutionary way. (1983b, p. 158)

Williams argues that this is 'quite central to Lukacs's thought' (1984a: p. 15). Indeed, the passage is redolent with the kinds of intuitive emphases that Williams had always thought proper to literary and social analysis. In Lukacs's desire to fuse his public and private aspirations we can hear echoes, displaced into the context of an intellectual's life and work, of Williams's long-standing aspiration for a realism which would authentically attend to the dialectical interrelation of subject and object. In the notion of coming 'to terms with the novel reality' a clear emphasis emerges on the subjective response to social experience which Williams found so central a consideration in pinning down the nature of class consciousness. There can be no dividing, in this model, the personal aspirations of the individual from his or her class's collective aspiration for emancipation; these are 'not any aspirations, but those learned from and centred in a changing reality' (p. 15) In Lukacs's fusion of his personal life with his political and intellectual commitments, if not in his simplifying self-portrait, Williams finds a trace of the Lukacs whose work had first inspired him in the sixties: a Lukacs alive to the absolute necessity of attending to the personal responses of those who labour under capitalism; a Lukacs from whom the notion of a consciousness imputed from on high seems quite distant. For a moment, in this, Williams's final engagement with Lukacs, the 'man without frustration', the intellectual who simply has his view and his commitments and divorces them from his affective life, is not present, and a recovered Williams can feel somewhat at home. And yet, for all that, Lukacs remains insistent: only Lenin fully understood these problematics. 


\section{Chapter Two}

\section{Williams and Sartre: Tragedy, Freedom, Nation}

\section{An Outline of Williams's Engagement with Sartre}

Lukacs's Record of a Life was not the only auto/biographical work by a European thinker Williams reviewed in 1984; he also reviewed Simone de Beauvoir's Adieux: A Farewell to Sartre, in which details of the last ten years of Sartre's life introduce, much as in Lukacs's Record, wide-ranging transcribed interviews. Sartre had died in 1980, but perhaps what is most interesting about the review is the manner in which Williams suggests he had already 'bid adieu' to Sartre some time before: 'The move from history to biography, and then to a kind of exposed biographical living ... is the point at which, many years ago, one said adieu to Sartre, though still respecting the fierce energy and the rigour, and the different adieux of those who loved him within his singular and intransigent circle' (1984b, p. 470). When did this move 'from history to biography', with which Williams broke with Sartre, occur? This is difficult to judge; it seems likely that Williams is referring to Sartre's unfinished, threevolume existential-psychoanalytic biography of Flaubert, The Family Idiot (1971-72), a work which more than any other of Sartre's sought to comprehend the 'meaning' of one man and his work. Williams is really dealing with two turning points in Sartre's career in this review: a) the movement from the early, necessarily subjectivist existentialist works to the publication of the more Marxist and historically engaged Critique of Dialectical Reason (1960), and b) a period of, as it were, 're-subjectification' in the later biographical output. In a sense, then, the full movement Williams is describing is from biography to history and back to biography again. Williams (1984b) expresses this trajectory in both a psychological and a literary register:

There was a time, in the sixties, when the engaging paradoxes of the earlier work seemed to have been taken to a new objectivity of inquiry: a movement, one might say, from a subjective sense of historical situation to exploration of a common and general history. It is now clear, from the whole trajectory, that this was not a culmination; it was a heroic phase, ending in failure and then in relapse. But even his failure is of great intellectual and symptomatic importance. (1984, p. 470) 
The period of the Critique was 'heroic'; it is a sign of Williams's esteem for Sartre that he does not say 'tragic', perhaps the more apt description given what Williams sees as Sartre's 'failure' and 'relapse', and a word which would have conjured his critical analyses of Sartre's plays in Modern Tragedy. Williams will argue that one of the greatest barriers to Sartre's further progress was his over-engagement with psychoanalysis or 'Freudianism'. And yet, it is only from a psychoanalytic perspective that we might ask whether there was something in Sartre's original formulations that dictated there should be a 'return of the repressed' postCritique, a return of the voluntaristic atmosphere which pervaded existentialism, and rendered it a difficult fellow traveller with Marxism.

At the core of Williams's definition of the failure of Sartre's heroic phase is the sense that Sartre was both the product of his time (influenced by the residual and dominant strains in his society) and the purveyor of original or emergent ideas which, from the beginning, were not sufficiently distinguishable from certain bourgeois philosophic and moral orthodoxies:

[Sartre] went into this inquiry with certain profound orientations which at the end and over and above what can be seen as an inevitable, because in its time very general, failure - stand out as barriers to the project. It is not only the persistent bourgeois position that one's freedom is constrained by the freedoms of others. It is also the voluntarism: [quoting Sartre] 'One is concerned with men who would be equal if they would make a slight change in their attitude, but who in their present state are countermen'. ${ }^{63}$ (1984b, p. 470)

We can infer what Williams means by a 'very general' failure by referring to two related statements in his 1974 review of Sartre's Between Existentialism and Marxism, in which he a) describes what he sees as a general weakness among the French Left-intelligentsia and b) asserts the inflexible and dogmatic nature of a certain kind of orthodox Marxism:

[Sartre's difficulties] remain, for me, centred in the problem of the relation with psychoanalysis. Sartre maintains a stubborn reservation about what he calls, accurately, the mythology of Freudianism, but it is clear that he is hard pressed by the prevailing structures of French neo-Marxism in just this area which is its confident and insistent weakness. (The Guardian, 1974, April 25)

What Sartre is trying to do, as a Marxist, is to restore individual and collective response and responsibility to a system which had become, internally, abstract and falsely determinist. (The Guardian, 1974, April 25)

\footnotetext{
${ }^{63}$ I have not been able to locate the source for this quotation.
} 
There is much to unpack in these three statements. What is crucial to note for now is the critical thread Williams is drawing between orthodox Marxism, psychoanalysis and existentialism, as discourses and as (political/clinical/philosophic) practices. In Modern Tragedy, which I will discuss extensively in the section on Sartre's drama, Williams argues that 'the three characteristically new forms of thinking, in our own time - Marxism, Freudianism, Existentialism - are all, in their most common forms, tragic' (1966, p. 189). The phrase 'in their most common forms' is important because, as we know, Williams's own work will eventually attempt to assert an alternative and affirmative position within the Marxist tradition. Nevertheless, Williams is emphatic in drawing together these three twentieth-century traditions under the umbrella of a tragic discourse which, whether in the mechanistic and deterministic manner of orthodox Marxism, the pseudo-bourgeois voluntarism of Sartrean existentialism or the psychoanalytic vision of individuals in permanent conflict with society, evinces a view of human nature and freedom which fails to acknowledge the considerable emancipatory resources human beings hold in common.

It should not be taken, from the above, that Williams's judgement on Sartre was damning. Sartre never receives anything resembling the upbraiding that Lukacs received on the basis of his Essays on Realism, and indeed Williams overwhelmingly appears to esteem Sartre as a man of character and compassion. In the review of de Beauvoir's text Williams notes Sartre's 'characteristically brave identification with the most extreme and exposed individuals and movements' (1984b, p. 470) in a period, from the mid-fifties onwards, in which the atmosphere of cold war and the regressive foreign and domestic policy of the Soviet Union had led to 'the simple contrast between communism and liberty which, in so many cases, and to a shameful extent in France, ends with an accommodation to capitalism ${ }^{64}$ (p. 470). Sartre, says Williams, even though 'despairing of the [communist] project, after the suppression of the Prague Spring, was incapable of that kind of accommodation' (p. 470), his constant mission being 'the attempt to recover communism for liberty - still the central project of our time' (p. 470). Such a project, in the sixties and seventies, was required to intersect at innumerable points with struggles that could not be fitted cleanly into the class struggle, engaging Sartre in a myriad of progressive causes, perhaps most significantly the national liberation struggles of the period. Williams writes, glowingly: 'His intense recognition of the

\footnotetext{
${ }^{64}$ Williams may be thinking here of the French 'New Philosophers' around Bernard-Henry Levi and Andre Glucksmann, former leftists who, from the mid-seventies, denounced both Marxism and communism and declared for liberal-democratic capitalism (and later neo-conservatism).
} 
victims of every kind of oppression, and both his courage and his conscious use of his celebrity to protect others, led him again and again to denounce tyranny and exploitation wherever they occurred: a rare and invaluable position within the polarisation and opportunism of a continuing cold war. From a distance, and now also when we see its close details, this stand should engage our immense respect' (p. 470). As we shall see, the issue of commitment, both in in politics and literature, is one of the most significant components of Williams's reception of Sartre.

Sartre's intellectual and political commitment to the causes he championed is a quality which signals, for Williams (1968b), a difference in consciousness between 'England' and the continent: 'Sartre is not a writer and thinker who takes time off for politics and journalism: that familiar English account in which thinking is a professional activity, a job, and politics is another professional activity, on which amateurs may sometimes intrude' (The Guardian, 1968b, Nov 29, p. 11). From his reception of Lukacs and Goldmann we know that Williams was highly critical of the English literary establishment, and that he was conscious of England lagging behind the continent in its engagement with what Williams saw as the crucial questions facing the politically aware critic of literature and culture. In his review of Iris Murdoch's Sartre, Romantic Rationalist in 1967, Williams is equally disparaging of what he sees as the elitism and lack of imagination of the British philosophical establishment, at that time almost entirely analytic in orientation:

Since an icy upper-middle-class voice took over rational discourse in England, people have been frightened of what they think of as philosophy, and have developed a kind of bored awe. Yet "philosopher" still sounds forbidding, and "Oxford philosophy", vaguely imagined as a prodigious intellectual exercise about returning a book to a friend, especially so. (The Guardian, 1967b, May 12, p. 8)

Sartre had strongly criticised the classical formulations of dialectical materialism (Marxist philosophy since Engels) in the Critique. Williams appreciated the way Sartre was seeking to reformulate the postulates of classical/orthodox Marxism without assimilating the analyticempiricist assumptions of the Anglo-American philosophical establishment, traditionally the hardest opponents of Marxism as a metaphysical or epistemological position (though this does not stop Williams from criticising what he does see as a bourgeois strain within Sartrean existentialism). Time and again in his engagement with European thinkers, and even where he finally and decisively parts ways with them, Williams is finding productive seams of thought which seem to hold the promise of resolving deadlocks within the intellectual 
Anglosphere. Rarely, if ever, are these deadlocks resolved to Williams's satisfaction, but each attempt is a step towards a new and productive emergence, so that even the failures of thinkers like Sartre (and Lukacs) are 'of great intellectual and symptomatic importance'.

A key difference between Williams's receptions of Sartre and Lukacs is the issue of access and translation. Inglis (1995) implies a less than perfect aptitude when he says that Williams 'didn't read French for fun' (1995, p. 145), but the fact remains that Williams read French, and could therefore have read Sartre at any point following the French publications. In stark contrast to Lukacs's major works, the bulk of Sartre's output, for reasons of celebrity and commercial impact in the immediate post-war era, was very rapidly translated. All but one of the plays Williams discusses in Modern Tragedy were published in English within three years of the French; Nausea (1943) and the Roads to Freedom (1945-1949) trilogy found translation just as rapidly. Sartre's major philosophical works, Being and Nothingness (1943) and the Critique (1960), took longer, at thirteen and sixteen years respectively; while it seems unlikely that Williams would have read either of these highly complex texts to completion in French, he could nonetheless have read passages or fragments, as well as reviews and analysis in French, close to their French publication. In the case of Lukacs, we were aware that Williams could have read a number of English translations which he did not directly comment upon in print. With Sartre these unknown but potential engagements extend to his entire corpus in French. Nevertheless, we must proceed on the basis of what we know Williams to have read, or can reasonably infer from his commentaries; fortunately, as with Lukacs, Williams's published pronouncements on Sartre are considerable, spanning almost the full length of his career. Here I provide an outline of that engagement, followed by a brief commentary.

In 1947, one of the pieces on literature and political commitment that Sartre was gradually publishing in the journal Les Temps Modernes and in Situations I (1947) and II (1948) was published in English translation in Politics and Letters, the literary-political journal Williams co-founded and edited following the completion of his studies at Cambridge. This piece, entitled 'What is Writing?', would comprise the opening chapter of Sartre's What is Literature? (French 1948), published in English in its entirety in 1950. While 'What is Writing?' was published on its own in English in 1948 by the Paris-based literary journal 
Transition, the 1947 translation in Politics and Letters is, to my knowledge, the earliest English version of the text. The interesting question then, of course, is whether Williams himself was the translator; the edition of Politics and Letters does not inform us, so we cannot be sure. Nevertheless, the inclusion of the piece in so early a publication of Williams's signals a very early familiarity with Sartre's work (I have mentioned the rapidity with which Sartre's fiction was being translated), and is an early acknowledgment by Williams that Sartre would be a significant figure for thinking through the relationship between literature and politics. The first time Williams refers to Sartre in his own words is in Drama from Ibsen to Eliot (1953); the brief material on Sartre here would be considerably expanded in the ...to Brecht version. In both versions, a single play is treated: Sartre's The Flies (F. 1943, E. 1946). Following this we find a gap of eight years (1953-1961) in which Williams does not explicitly engage with Sartre in his published writings (he may well have read some of Sartre's on-going output in French and English).

Williams's first serious engagement with existentialist themes comes in The Long Revolution (1961), in which Williams assesses the contribution of existentialism to debates around the individual and society. While Williams does not refer to any specific texts here, his engagement with the concepts of 'authenticity' and 'inauthenticity', terms which, in English translation, originate in Heidegger's Being and Time (1927) (Sartre generally prefers 'good faith' and 'bad faith'), indicates familiarity with existentialist arguments. Sartre is mentioned by name, and that Williams refers to Sartre's use of the terms 'function' and 'duty' (2011b [1961], p. 110) suggests that he has at least read the chapter on 'Bad Faith' in Being and Nothingness (F. 1943, E. 1956), in which these terms appear. The next engagement, and perhaps the most significant for Williams's views on the function of literature/art, comes in 1966 with Williams's critical analysis of Sartrean drama in Modern Tragedy. Here Williams provides readings of six of Sartre's plays: The Flies (F. 1943, E. 1946), No Exit (F. 1945, E. 1946), Men Without Shadows (F. 1946, E. 1949), Dirty Hands (F. 1948, E. 1949), The Devil and the Good Lord (F. 1951, E. 1960) and Altona (F. 1959, E. 1960) alongside works by Camus and Brecht. In 1967 Williams reviews Iris Murdoch's earlier work Sartre, Romantic Rationalist (1953 - this text deals primarily with Sartre's novels, suggesting that Williams was broadly familiar with them), and in 1968 (alongside the material on The Flies in DFIB), he reviews the essay collection The Philosophy of Jean-Paul Sartre (1968), edited by Robert Denoon Cumming. In the latter review, Williams actually quotes from Sartre's Critique, 
which was not yet available in English, indicating that he had at least read parts of it in French as of 1968.

In 1972, Sartre (with his Critique), appears alongside Lukacs and Gramsci as part of Marxism's 'alternative tradition'. In 1974 Williams reviews Sartre's Between Existentialism and Marxism (F. 1972, E. 1974) alongside two critical texts, Sartre (1973) by Hazel E. Barnes and Camus and Sartre (1974) by Germaine Brie. Two years later, in 1976, Williams includes 'existential' as an entry in his Keywords, elaborating on the development to 'existentialism' after 1945, due in large part to Sartre's influence. In 1977, the year in which he publishes his own 'reckoning' with Marxism, Williams reviews Sartre's major theoretical engagement with the Marxist tradition, the Critique of Dialectical Reason (F. 1960, E. 1976). Williams also discusses the theme of commitment in literature and Sartre's poetry/prose distinction in Marxism and Literature (1977) and, in the same year, refers favourably to Sartre's position on the national liberation movement of the Basques in Spain in the essay 'Marxism, Poetry, Wales' in Poetry Wales. Williams's mention of Sartre's position in the latter text strongly suggests that he had read Sartre's essay 'The Burgos Trials' (1971), which had quickly appeared in English in the journal Planet: The Welsh Internationalist (19711972). Williams rounded off the seventies with some significant discussion of Sartre in the Politics and Letters interviews, including ruminations on Sartre's materialism, his concepts of 'seriality' and 'scarcity' in the Critique, and the relation of his pessimism to other strains of thought within contemporary Marxism. Williams also mentions Sartre in the context of the crucial question of hope in politics in his afterword to the 1979 edition of Modern Tragedy. In 1980, Williams returns to the issue of commitment in literature with the significant essay 'The Writer: Commitment and Alignment' in Marxism Today; Sartre's position is mentioned as in many ways the linchpin of debates around the subject. In 1984 we have the abovementioned review of de Beauvoir's Adieux: A Farewell to Sartre, and in 1985 Williams briefly mentions Sartre in the context of non-economic interpersonal relations in his lecture 'Cinema and Socialism', appearing in print for the first time in The Politics of Modernism (1989).

In summary, then, we know that Williams reads or comments on the following texts by or about Sartre. Texts are by Sartre unless otherwise indicated and are listed in chronological order of mention by Williams, with French and English dates of publication: 
1947: 'What is Writing' (French: 1947, English: 1947)

1953: The Flies (French: 1943, English: 1946)

1961: Being and Nothingness [at least the 'Bad Faith' chapter] (French: 1943, English: 1956)

1966: No Exit (French: 1945, English: 1946), Men Without Shadows (French: 1946, English: 1949), Dirty Hands (French: 1948, English: 1949), The Devil and the Good Lord (French: 1951, English: 1960) and Altona (French: 1959, English: 1960)

1967: Sartre, Romantic Rationalist by Iris Murdoch (1953)

1968: The Philosophy of Jean-Paul Sartre edited by Robert Denoon Cumming (1968), Critique of Dialectical Reason (French: 1960, English: 1976)

1974: Between Marxism and Existentialism (French: 1972, English: 1974), Sartre by Hazel E. Barnes (1973), Camus and Sartre by Germaine Brie (1974)

1977: 'The Burgos Trials’ (French: 1971, English: 1971)

1984: Adieux: A Farewell to Sartre by Simone de Beauvoir (French: 1981, English: 1984)

The first thing to note about the above chronology is that, in comparison with Lukacs, Williams is 'dealing with' Sartre roughly a decade earlier. The translation of 'What is Writing?' in Politics and Letters comes fifteen years before Williams's first writings on Lukacs (1962). Williams's engagement with Lukacs in the sixties is confined to two reviews, whereas his engagement with Sartre in that decade comprises six plays, parts of Being and Nothingness and two reviews of critical texts. By the mid-seventies Williams had probably read everything on Sartre that he would comment on (with the exception of de Beauvoir's book) in his lifetime, whereas he was still discovering newly translated texts of Lukacs into the eighties. This is so despite the fact that Lukacs began his career and died roughly a decade earlier than Sartre; the over-riding reasons are, of course, Williams's language ability and relative speeds of translation. Broadly speaking, then, the key decades for Williams's engagement with Lukacs are the seventies and eighties, for Sartre the sixties and seventies. That the overlapping decade is the seventies is in keeping with the general acceleration in translation of the fundamental texts of European or Western Marxism in the immediate post1968 era. 
A second observation relates directly to the first. One of my contentions in chapter one was that Williams's opinion of Lukacs declines over time, roughly in keeping with the intensification of Williams's own engagement with Marxism up to Marxism and Literature, a text which evinces a Marxist perspective significantly at odds with Lukacs's. Williams's position on Sartre, beginning critically, peaking with the Critique and declining again in the early seventies, is relatively settled prior to the period of Marxism and Literature and the explicit affirmation of the Marxist character of cultural materialism. While it is still the case that Williams is reading or commenting on some of Sartre's works during the period of his own theoretical transition, his encounters with Sartre's output occur earlier and in a more concentrated form than with Lukacs, and there is a lack of the sense of sudden discovery and re-orientation that obtains, for example, in Williams's commentaries on History and Class Consciousness or Essays on Realism. Williams's engagement with Sartre is steadier, earlier and more linear, following the contours of Sartre's career more or less in real time, and permitting Williams a more accurate and complete image of Sartre's development. As noted above, this chapter will be structured along more thematic than strictly chronological lines.

The key cultural issue in Williams's writing on Lukacs was that of literary realism; the key political issue was that of class consciousness. With Sartre, I think, the predominant cultural issue is that of commitment in art, the predominant political issue the relation of the individual to society. At stake in both is the question of freedom, and so the theoretical spine of the following discussion will be the relation of both Williams and Sartre's thought to the notion of human freedom and its intellectual corollary under capitalist social relations: political liberalism. Williams's criticisms of existentialism in the 1960's and beyond, both as a philosophical doctrine and as a structure of feeling within literature, stem from his rejection of the stance, which he sees as absorbed from a certain kind of bourgeois ideology, that the freedom of the individual is antithetical to inclusion within, or partial determination by, a social structure. We will find an inherited strain of liberalism in Williams's thought, alongside its socialist obverse: frustration with the liberal (or libertarian) equation of freedom with radical individualism. In his After Theory (2004), Eagleton puts the distinction between liberal and socialist conceptions of freedom into relief:

If human beings naturally live in political society, we can either try to arrange political life so that they all realize their unique capacities without getting in each other's way, a doctrine known as liberalism; or we can try to organize political institutions so that their self-realization is as far as possible reciprocal, a theory known as socialism. One reason for judging socialism to be superior to liberalism is the belief 
that human beings are political animals not only in the sense that they have to take account of each other's need for fulfillment, but that in fact they achieve their deepest fulfillment only in terms of each other. (2004, p. 122)

Eagleton is simplifying and is not, of course, saying that liberalism, in the Thatcherite manner, does not 'believe' in society; the point is that liberalism regards the formation of political institutions as a means to establish negative liberty for individuals, traditionally conceived of as freedom from others. Socialism, in contrast, regards political institutions as enablers of a common and reciprocal prosperity, in which individual freedom is theorized as achievable only through others, by means of common resources employed in solidarity. Sartre, of course, was not a liberal politically, and indeed the relationship between Sartrean existentialism and liberalism would itself require the devotion of a thesis. The question of whether a philosophical position and an ethics based on a radicalism of individual freedom can contribute to the socialist project is a key one for Williams in assessing Sartre. His is a mixed response, acknowledging the validity and power of the goal of 'restoring communism for liberty' while criticizing the vulnerability of Sartre's work both to lapses in the rigour of its author's anti-bourgeois assumptions, and to misinterpretation by the libertarian zeitgeist of the late sixties. Clearly, Williams's reception of Sartre also provides an opportunity to interrogate Williams's own liberal inheritance, the tension therein, and his own conception of human freedom, individual and social. Let us begin with a topic which presages in interesting ways these more philosophical and political concerns: the social and aesthetic nature of tragedy.

\section{The modern tragedy is the Sartrean tragedy}

Williams's book-length discussions of drama in Drama from Ibsen to Eliot (1952 - hereafter DFIE), Drama in Performance (1954), Modern Tragedy (1966) and Drama from Ibsen to Brecht (1968 - hereafter DFIB) form the backbone of his literary criticism before a turn towards the novel with The English Novel from Dickens to Lawrence in 1970. The European dimension of this body of work is largely absent in the early DFIE, which Williams acknowledges is a weakness: 'There are omissions I regret, where the opportunity to see and read important recent work in the European theatre was not available' (1967a, p. 43); ${ }^{65}$ the engagement develops apace in the later texts. It was precisely during the period between

\footnotetext{
${ }^{65}$ In addition to the European dramatists mentioned in the following quotation, Williams also became familiar with Scandinavian drama during this period. In a 1965 review of Evert Sprinchorn's collection, The Genius of Scandinavian Theatre (1964), Williams bemoans the absence of Bjornson, Grieg, Munk and Hjalmar Bergman, along with the screenplays of Ingmar Bergman, from Sprinchorn's account.
} 
DFIE and DFIB (the latter a wholesale revision and extension of the former) that Williams noticed the increasing influence of contemporary European drama on 'English' practice, as he recounts in a new conclusion for the 1963 edition of the DFIE:

A very important recovery of European and American drama was widening the sense of possibility in English drama ... The first influence was undoubtedly the reopening of the English theatre to the full range of European practice. The work of Anouilh, Sartre, Brecht, Beckett, Giradoux, Ionesco came as a revelation, especially since people were feeling that elsewhere only mannerism and the commercial theatre was left. Much of the work, especially that of Brecht and Beckett, realized, in practice, what the revival of verse drama [Eliot] had originally been about: the expansion of dramatic action and speech to a more vital and more extended human range. (1983b, p. 303)

The process of 'widening', 'reopening' and 'expansion' is never a finished process, and what begins as a critique of the limitations of naturalism in DFIE becomes, by $D F I B$, equally a critique of expressionism, with Brecht pushing at the outer edges of what has been achieved as far as social critique. Modern Tragedy is the clearest expression of what is really at stake in Williams's critique of modern drama, not a formal critique but a critique at the level of a structure of feeling common to both major forms and realized fully in neither. It is a structure of feeling which aims at a fully human truth, shorn of external designs or elite interference (Lukacs's 'imputed class consciousness', for example), but which is nevertheless embedded within a class society and cannot but express the resulting tensions and contradictions. In Modern Tragedy this is given a politico-aesthetic formulation as the interaction between revolution and tragedy, with the dramatists Williams selects to examine presented as 'stages' in this interaction. Brecht is the last stage, as of Williams's writing, and Sartre the penultimate one (literally, in the progression of chapters; theoretically, in the argument). Preparatory to interrogating Williams's reading of Sartre's plays, then, it will be worth examining Williams's account of the tragic structure of feeling he sees as constitutive of modern drama.

I will bluntly state the case at the outset: Williams is for revolution as a total process and against the pessimism of a certain modern conception of tragedy based on an indifferent universe and isolated human nature. 'Hope' is not a theoretical category for Williams, but it persists as an affective through-line throughout his work. Williams's opposition to the Leninist/Lukacsian model is a rejoinder to the cynicism implicit in the notion that ordinary people are incapable of coming to emancipatory conclusions under their own experiential and cognitive power. This is at the root of his humanism, and we saw it in his rejection of 
Lukacs's view of realism: the model of truth and resistance to which realism aspires cannot be that of an abstract, objective (in the sense of beyond human experience) and thus alienated system of mechanical laws. We noted that in Politics and Letters (2015 [1979]), Williams's interlocutors pull him up on using a definition of realism which is really that of the preMarxist Lukacs of The Theory of the Novel (1916), as 'the action of a man or woman who seeks a freer life with a greater attainment of value in it and finds the society an insuperable barrier, the ratification of the quest, yet at the same time the representation of the society' (2015, p. 222). Now, while this is not the version of realism in the novel which Williams puts forward in his own work nor, as a rule, what he criticizes Lukacs for advocating, the old (preMarxist) Lukacsian model is reminiscent of Williams's analysis and critique of dramatic naturalism, an analysis which bleeds into the critique of expressionism in DFIB.

$D F I E$ is a critique of naturalism on the grounds that its formal conventions, namely, the reproduction of 'everyday' or 'lifelike' speech, settings and scenarios, in fact effect only a shallow simulation of reality: "The naturalist dramatists wanted to produce "the illusion of reality". (The unconscious irony of the phrase is perhaps the final critical judgment of naturalism)' (1967a, pp. 25-26). What is lacking in naturalism is what Williams calls, following Eliot, a 'deeper consistency ... the "reduction" to essentials ... of living experience; the refusal to be distracted by the "natural surface experience". It is the consistency of art rather than the consistency of representation' (p. 24). In DFIE, Williams sees this consistency as only practicable under the strict authorial control of the dramatist and with strict proximity to what he calls the 'community of sensibility':

The moral activity of the artist [i.e. 'intentional' expression of experience/sensibility] can also be an individual perception of pattern, or structure, in experience; a process which involves the most intense and conscious response to new elements of substantial living, so that by this very consciousness new patterns of evaluation are created or former patterns reaffirmed. In an age of widespread community of individual belief, the conventions of this process are clearly easier to establish, and full communication is more likely. But at all times, the community between artist and audience which seems to matter is the community of sensibility. (1967a, p. 31)

This is clearly an early formulation of what would become one of Williams's lasting theoretical legacies, the 'structure of feeling', but also the later 'knowable community' of The English Novel. Here the idea is general but, in DFIB, Williams develops the 'structure of feeling' as it relates to drama specifically (it was developed as a general cultural category in TLR) and especially to dramatic conventions. 'Conventions' are formal qualities which carry collectively understood and tacitly agreed upon meanings: 'the convention, in any particular case, is simply the terms upon which author, 
performers and audience agree to meet' (Williams, 1983b, p. 4). In a naturalist play, then, 'the convention is that the speech and action should as closely as possible appear to be those of everyday life' (p. 4). As the common ground between dramatist and audience, conventions reflect a collective and intuitive experience of the totality of social life (i.e. a structure of feeling) in a given community in a given period. While we are accustomed to dividing social reality into empirically manageable chunks, Williams argues, 'in the living experience of the time every element was in solution, an inseparable part of a complex whole ... it is from such a totality that the artist draws' (p. 9). The artist will undoubtedly name parts of social reality, but what is being drawn on as the structure of feeling is an intangible set of whole relations: 'there yet remains some element for which there is no external counterpart. It is this, in the first instance, that I mean by the structure of feeling' (p. 10). The non-empirical nature of the structure of feeling (as precisely that which eludes separation and definition) means that Williams's position is both antiformalist and, to a limited degree, anti-representational. What matters is not what conventions express 'in themselves', or whether they express 'reality' (the goal to which naturalism aspired), but how they relate to the structure of feeling; a given set of conventions may help or hinder the artist's communication of experience of the totality which his/her creative act hopes to express and participate in. Already, Williams's commitment to totality is rendering his critical methodology incompatible with any simple empiricism.

Given these positions, Williams cannot regard the relationship between naturalism and expressionism as merely formal. Instead, Williams reads these forms as sharing an underlying structure of feeling that we can summarize as secular, humanist and tragic (Brecht, at his best, transcends this last quality). At its most basic level, 'naturalism' names a dramatic form evincing 'an absorbed interest in the contemporary everyday world, and a corresponding rejection or exclusion of any supposed external design or system of values' (Williams, 1983b, p. 382). But then the rejection of naturalism, and the rise of other forms such as expressionism, was not the rejection of 'too lifelike' a set of conventions, but the judgment of those conventions as 'no longer true enough, by essentially similar criteria' ( $p$. 383). Williams elaborates: 'It can then seem a rejection of naturalism to use conventions of speech, action and scene which are not, in immediate terms, probable, or superficially lifelike. But these new conventions, normally, have the same central purpose: a true representation of life' (p. 383). That 'true representation', however, is really a representation of a modern structure of feeling, in which the dominant sense is of a man-made world or context (as opposed to a theologically oriented one) within which, paradoxically, the 
individual person is thoroughly, even tragically, limited by that very man-made environment; it is the drama of "a uniquely representative figure (representative of "humanity" or "Man") who is in revolt against the representative environment other men have made' (p. 390). For Williams, this contradictory structure of feeling is inextricable from the development of bourgeois society:

The inner history of naturalism is really this: that it developed as a style $-\mathrm{a}$ characteristic way of handling the world - in bourgeois society, but that it developed as a form, capable of major dramatic importance, in a period in which bourgeois society was being fundamentally criticized and rejected, mainly by people who nevertheless belonged in its world. There is then a contradiction in naturalism, but also a tension out of which the great drama of Ibsen directly came. The style assumed an understandable, recognizable, manageable everyday world; the form, while linked to this, discovered a humanity which this same world was frustrating or destroying. (1983b, p. 389)

Both of the major modern dramatic forms, then, express the tension between a secular liberal humanism, which seeks to liberate man by freeing him from transcendental determination, and the socialist recognition of the reality of class in capitalist society. In other words, there exists in these forms a contradictory recognition, even if only unconsciously for the bourgeois practitioners of these forms, that humanism is not in itself a sufficient guarantor of freedom. Williams argued that a dissident, critical tension existed in naturalist plays between the realistically portrayed rooms, the everyday speech and scenarios, and the sense that the humanity which humanism had discovered was being stymied by the liberal capitalist order (or, in more philosophical terms, empiricism as an escape from transcendentalism was being problematized by a materialist recognition of the injustice inherent in the deep structures of a man-made social order). 'This real contradiction between style and form', argues Williams in $D F I B$, 'could not last forever, in serious drama' (p. 390). The result was a complex of adaptations in formal expression (conventions) that became known as expressionism:

The suppressed tension, of those many trapped rooms, now breaks to a redefinition of what any environment is. A dramatic world is made (and we are still mainly in this phase) in which it is human isolation that has become representative: another unique history, offered, even more paradoxically, as a general truth. What was still, in the patient reproduction of naturalism, a self-evidently man-made world, is now a phantasmagoria, a hostile projection, a parody of order. Out of this structure of feeling - in historical terms, out of the failure of bourgeois revolt against bourgeois society comes a new confidence: a confidence of despair ... the techniques were available, from traditional romantic literature, from the fragments of a supernatural order: visions, transformations, superhuman powers, a malignant nature ... It was not now in an order beyond man that these manifestations occurred; it was inside him, deep 
inside him, in dreams and in visions, in his own irreducible and most personal and significant life. (1983b, p. 391)

The dramatic action of the major expressionists, then, 'succeeds to, rather than contradicts, the great tensions of the major naturalist play' (p. 391). While expressionism uses a very different set of conventions, it communicates many of the same critical or dissident liberal intuitions as naturalism in 'what is really only a development of the structure of feeling' ( $p$. 391). Expressionism is the more pessimistic because the more inward-facing form, tending to wallow in 'despair, contempt and rejection' (p. 395); Sartre, while his work contains both naturalist and expressionist formal elements, falls primarily into the more severe affective space of expressionism. But it is clear that, for Williams, neither of the major forms go nearly far enough in their critique. This is because both forms proceed from an essentially tragic structure of feeling, 'a "rejection" of bourgeois society which was also, factually, a resigned or angry acceptance of it as inevitable' (p. 393). This, in effect, was the importation of an older, metaphysical notion of tragedy (as Fate), into a modern context in which it functions as the unrecognized projection of social and individual breakdown.

Modern Tragedy (1966), which is where the bulk of the material on Sartre's plays appears, is Williams's attempt to render revolution in a manner which neither rejects nor succumbs to tragedy, but rather incorporates it into the conceptual apparatus of modernity. But this will require a wholesale reassessment of the concept of tragedy as it has been applied in dramatic criticism. Williams argues that the conventional academic account of tragedy has tended to divorce it from people's everyday experiences. This critical tradition asserts that 'there has been tragedy', defined as dramatic actions embodying a certain metaphysical relation to Fate or a divine plan/will, 'but that lacking this belief, that rule, we are now incapable of it' (Williams, 1966, p. 45). A specifically modern tragedy, by this logic, is impossible because of the loss of a metaphysical order. Both ordinary tragic events, such as accidental deaths, and larger historical and political events, such as wars and revolutions, are by this cynical humanist logic excluded from the definition of tragic experience and action: 'The events which are not seen as tragic are deep in the pattern of our own culture: war, famine, work, traffic, politics. To see no ethical content or human agency in such events, or to say that we cannot connect them with general meanings, and especially with permanent and universal meanings, is to admit a strange and particular bankruptcy, which no rhetoric of tragedy can finally hide' (p. 49) A multitude of events, clearly imbued with a great deal of suffering and negativity and comprising a large part of what happens to people in modern society, are 
barred from participation in the potentially cathartic affective structures of tragedy and are reduced to the status of indifferent accidents. Both 'ethical content' and 'human agency' are, by a kind of humanist masochism, purged from the humanist experience of society in the period of industrialization, impairing our ability to take the full measure of periods of suffering and crisis by accepting our own active role in their development and resolution.

Williams argues that individualist liberalism, which played such a crucial role in the initial, emancipatory step of separating human values from abstract metaphysics (and, in doing so, sowing the seeds of revolutionary optimism), is 'especially responsible for the sharp opposition between the idea of tragedy and the idea of revolution which we find so clearly in our own time' (1966, p. 68). The deadlock of liberalism expresses itself as the naturalist paradox also discussed in $D F I B$, of a non-metaphysical world over which, because it is abstracted into a set of mechanical, law-like processes (as in both natural science and orthodox Marxism), human beings can have no control:

The tragedy of naturalism is the tragedy of passive suffering, and the suffering is passive because man can never really change his world ... the impulse to describe and so change a human condition has narrowed to the simple impulse to describe a condition in which there can be no intervention by God or man, the human act of will being tiny and insignificant within the vast material process, universal or social, which at once determines and is indifferent to human destiny. (1966, p. 69)

Recall that in DFIB Williams would characterize naturalism as the product of a period of bourgeois revolt, and expressionism as the product of the failure of that project, 'the failure of bourgeois revolt against bourgeois society'. Naturalism made society into a kind of machine, beyond all human contact, while expressionism, being the product of the failure of a liberal rebellion against that notion, made society per se, society as a concept, into the enemy of the individual, the source of his subjective anguish and isolation. Irrationalism emerges as a counter to the mechanical rationality of the previous phase, as does the rejection of all collective or social acts, including social revolution, as allied to an ineradicably hostile and oppressive external world. Both conceptions, argues Williams, are inevitably tragic; the first makes man impotent, the second either renders him or actively encourages him to be irrational, isolated and nomadic. In naive opposition to these tragic conceptions, argues Williams, stands 'utopianism, or revolutionary romanticism' (p. 77), the 'suppression or dilution' of the inescapable fact that revolution is tragic, that it is 'born in pity and terror: in the perception of a radical disorder ... in an experience of evil made the more intolerable by the conviction that it is not inevitable, but is the result of particular actions and choices' ( $p$. 
77). We thus remain stuck between an idea of tragedy that cannot incorporate the idea of revolution, and an idea of revolution which, obsessed with 'the total redemption of humanity', cannot incorporate the idea of tragedy.

Williams's solution is dialectical and totalizing. Revolution and tragedy share a genus in historical experience, namely, the living through by human beings in society of periods of acute social disorder, the crises which ensue and their often very painful resolution in the construction of a new order. The temptation to view the pain and suffering as 'merely' tragic, and thus as inimical to the emancipatory spirit of revolution, must be overcome. How is this to be done? First, an affirmation of socialism: 'Socialism, I believe, is the true and active inheritor of the impulse to human liberation' (1966, p. 74). Next, the humanist acknowledgment of our own involvement in revolution (and indeed tragedy) and the rejection of any purely objective/mechanical viewpoint: 'Elevating ourselves to spectators and judges, we suppress our own real role in any such action, or conclude, in a kind of indifference, that was has happened was inevitable and that there is even a law of inevitability' (p. 83).

Following this recognition of the tragic nature of revolution, wherein we 'see actual liberation as part of the same process which appalls us' (p. 82), comes the acceptance of the unbreakable dialectical bond between the two concepts and experiences: 'The tragic action, in its deepest sense, is not the confirmation of disorder, but its experience, its comprehension and its resolution. In our own time, this action is general, and its common name is revolution' (p. 83). Finally, Williams enjoins us to fully identify with the tragic experience of revolution as a means of furthering the emancipatory project initiated by humanism but stalled by the contradictions of liberalism, and by our own limited responses to the experience of tragedy: we must 'make the connections, because that is the action of tragedy, and what we learn in suffering is again revolution, because we acknowledge others as men and any such acknowledgement is the beginning of a struggle, as the continuing reality of our lives. Then to see revolution in this tragic perspective is the only way to maintain it' (pp. 83-84).

So, where does Sartre fit within Williams's complex dialectic of tragedy and revolution? It is instructive that the heading Williams gives to the Sartre (and Camus) chapter in Modern Tragedy is 'Tragic Despair and Revolt: Camus, Sartre'. The difference between the two tragedians is smaller, argues Williams, than Sartre believed it was. Sartre had contended that 'while Camus was ostensibly in revolt against historical suffering, he was less concerned to 
end this than to find a personally satisfying position: a metaphysical revolt against an eternal injustice' (1966, p. 184); Williams is quick to point out, however, that Sartre 'shares with Camus those perceptions of the absurd which are the starting point of the metaphysical rebel' (p. 185). Camus's attempt at an emancipatory humanism, argues Williams, which would deny the inevitability of despair, was hampered by the consistent location of revolt in the isolated individual, collectivity being reserved for the negative pole of suffering:

Thus while the suffering is genuinely collective, the revolt is inevitably individual. The last rhythm of liberal tragedy is again heard. The capacity of history to change the common condition, is any essential way, is implicitly denied. Thus revolt is sharply distinguished from revolution. (1966, p. 183)

Revolution, then, as collective revolt. It is worth recalling in this context Williams's discussion of the different positions an individual may take towards society in TLR. There Williams defined, as conservative positions, the 'member' as the person who whole-heartedly endorses and identifies with the purposes of their society, the 'subject' as the person who makes no such identification but is forced by material necessity to conform, and the 'servant' as the person who is only partly, to use an Althusserian term, interpellated; the servant becomes aware, through deep personal suffering, of the gulf between the purposes of (class) society and the possibility of living a full life, but nevertheless 'plays the role as if it were really his' (Williams, 2011b [1961], p. 112), denying the necessity of rebellion as well as his own capacity to rebel. Williams terms this the 'servant complex' (p. 113), and places it in direct opposition to existentialist doctrine. The existentialist, concerned to adopt an authentic and responsible position with regards to his/her choices, 'refuses this complex, and asserts the centrality of personal choice. From this position, with the reality of membership virtually excluded as a possibility, the whole repertory of modern individualism proceeds' (p. 113). As in Camus, then, the refusal of identification with a social edifice that produces 'despair' issues forth in a merely individual revolt, a revolt perennially limited by its association of society tout court (in short, other people) with the alienating pressures that are felt and theorized as absurdity (this is very close to Williams's general critique of expressionism). Sartrean drama will follow a similar, if more militant, existentialist trajectory.

Williams's analysis of Sartre's plays in Modern Tragedy nuances what were quite dismissive comments in DFIE, in which he suggested that Sartre's dramatic output was less that of a dramatist, and more that of a philosopher, contrasting him unfavourably with his fellow Frenchman, the playwright Anouilh: 'Sartre ... is fundamentally a melodramatist, and [his] 
opinions are more interesting than the plays which express them ... Anouilh's achievement is, like that of Ibsen, the achievement of a dramatist, and not of a philosopher' (Williams, 1967a, pp. 221-222). This was based on the following critique of Sartre's The Flies (1943), in which the Orestes and Electra myth is reformulated as a kind of existentialist parable: 'it is Orestes's refusal of guilt, Sartre's modification of the legend, which is the main interest. But in Sartre's play one's attention is directed to the philosophical change, and the legend is not so much a form as a case. The philosophical interest in indeed considerable, but the play is an example of a gain in interest at the expense of intensity' (p. 221). Such broad-brush valuejudgements are indicative of Williams's pre-cultural materialist or 'practical critical' period (DFIE is an explicit attempt to apply practical criticism to drama); the argument is considerably advanced in Modern Tragedy but retains the, I think correct, view that the engine of Sartre's drama is his philosophy.

In Modern Tragedy Williams tackles six of Sartre's plays (including The Flies) from across the latter's career, producing an overview of Sartre's development as a dramatist from his existentialist roots to the Marxism of his mid-to-late period. Williams works chronologically, beginning with The Flies. Here, he argues, Sartre produces a paradigmatic metaphysical rebel in the personage of Orestes, whose refusal of any metaphysical order beyond man liberates Argos from the tyrannical Aegisthus, backed by Zeus. In the cosmos of Sartre's play, gods exist (Zeus is a major character), but influence human affairs only under cover of the lie that they are all-powerful; in reality, the gods have no power and men are fully free. The realisation of this fact by the hero and its communication to others is then the focus of the dramatic action, effectively elevating the revelation of an existentialist metaphysical doctrine to the level both of moral imperative and dramatic catharsis. The adaptation of the form of Greek tragedy is a technical tool towards philosophical revelation, and that revelation is the form taken by the revolt. As Williams puts it: 'By the form of the Greek story, [Orestes] is the man destined to the decisive action; thus the metaphysical rebel can be seen also as the liberating hero' (1966, p. 185). The play itself corroborates Williams's sense that, in Sartrean drama, collective revolt is off the table. It is Orestes, not the people of Argos themselves, who performs the reversal of false consciousness. Furthermore, Orestes only frees the people via a strange act of self-sacrifice, drawing to himself the pestilence of flies, representative of the false unfreedom of Argos, and leaving the kingdom forever. All responsibility now lies with Orestes, and by a kind of messianic 'positive alienation', the people are delivered into freedom. We are firmly in the realm of imputed class consciousness, of Leninist elitism, 
when Orestes benevolently accepts the position of king but vows to be a king 'without subjects':

Now I am of your kind, my subjects; there is a bond of blood between us, and I have earned my kingship over you. As for your sins and your remorse, your night-fears, and the crime Aegisthus committed - all are mine, I take them all upon me. Fear your dead no longer; they are my dead. And, see, your faithful flies have left you and come to me. But have no fear, people of Argos. I shall not sit on my victim's throne or take the scepter in my blood-stained hands. A God offered it to me, and I said no. I wish to be a king without a kingdom, without subjects. (Sartre, 1989c, p. 123)

A king without subjects, of course, is still a king. The metaphysical rebel refuses to rule but leaves intact the distinction between those who rule and those who do not. The implication that it is possible to speak and act in the interest of all men without ruling them is progressive in a limited, liberal sense, but falls far short of what Williams defines as revolution: collective revolt enacted with an acknowledged and responsible involvement in suffering. The people of Argos do neither.

The Flies is fully consistent with the philosophical ideas of the early Sartre. In Existentialism is a Humanism (1946), Sartre presented the following view on the relationship between individual and collective ethics/freedom:

When we say that man chooses himself, we do mean that every one of us must choose himself; but by that we also mean that in choosing for himself he chooses for all men. For in effect, of all the actions a man may take in order to create himself as he wills to be, there is not one which is not creative, at the same time, of an image of man such as he believes he ought to be ... When a man commits himself to anything, fully realising that he is not only choosing what he will be, but is thereby at the same time a legislator deciding for the whole of mankind - in such a moment a man cannot escape from the sense of complete and profound responsibility. (Sartre, 2007, pp. 31-33)

The formulation fits Orestes perfectly; not a King in the traditional sense, but nevertheless a 'legislator deciding for the whole of mankind', burdened by that responsibility (the flies are transformed from a symbol of bad faith into Sartrean 'anguish', the trans-personal, but not properly collective, burden of ethical choice). As Williams puts it during a third discussion of the play in $D F I B$, 'It is not the revolt of the citizens, as in Alfieri or Voltaire, which liberates the city. Their freedom is brought to them, by the desperate outsider, who in acting for himself is acting for them' $(1983$, p. 256). This is the action of the metaphysical rebel, the figure who goes beyond the simple, fully individualized metaphysical angst of Antoine Roquentin in Sartre's Nausea (1938), pushes through to social critique (revolt) but falls short of historical solutions. In this sense, The Flies bears the archetypal political weakness that 
Williams attributes to expressionism more generally: the manifestations of social disorder, their experience and their working through occurring entirely within the critical consciousness of the far-seeing individual.

In Modern Tragedy (1966), Williams argues that a welcome shift onto the terrain of history begins with Sartre's Les Mains Sales (Dirty Hands) (1948), the story of Hugo Barine, a communist and reluctant assassin who goes through with the hit only when he sees his victim in a romantic liaison with his wife. The target, Hoederer, is a fellow party member whom Hugo's superiors believe was about to make a damaging strategic blunder. The action postassassination focuses on the question of Hugo's real motives: political duty or passionate jealousy in the moment? The meaning of this complex interplay between motive and outcome is further obfuscated by the fact that Hugo's superiors belatedly come to believe that Hoederer's strategy was in fact the right one. Williams is scathing of the political implications of such multi-layered uncertainties:

It is possible to read it as in part the familiar Freudian gloss on historical actions: Hugo could not kill Hoederer for public reasons, but he can kill him in personal jealousy. The public reasons are themselves made ambiguous by the shift in the party line which makes Hoederer first a traitor and then a hero. Of such ironic reveals and ambiguities of motive, history, the play seems to assert, is in fact composed. Authenticity is then a matter of personal intention, of the meaning given to the act by the man who commits it. Other kinds of meaning are inevitably secondary and confused. This is then still the morality of revolt, and not of revolution. A personal meaning can be asserted, but there are no effective meanings beyond this. (1966, p. 185)

In the absence of an authoritative account of history, then, authenticity is what the person involves makes of it, their 'version of events'. Williams's analysis is in many ways adequate, but his account of authenticity is lacking, and an important sexual dimension of the play is left untouched. After the assassination, Hugo's life is at risk from the party, since because Hoederer's strategy turned out to be right, it is now Hugo who is 'objectively' the traitor. Hugo refuses to please guilty to a 'crime of passion', insisting that he really did believe, and still does, that Hoederer was wrong. At this level, the play implies, Hugo is being inauthentic, attributing false motives to his actions. However, a homoerotic subtext in the play strongly suggests that Hugo in fact loved Hoederer, not his wife, and that the murder was one of erotic rage directed at the male object of his desire. At this level, Hugo is right to say that the murder was not the crime of passion his friends hope it was; it was, in fact, a quite different crime of passion. But by holding onto the face-saving and, in this case, heteronormative 
narrative of dispassionate political service, his action remains 'inauthentic'. Williams is right to assert that the play offers no metric by which to judge the adequacy of different political strategies or ethical commitments. But as a reading of authenticity in the early Sartre, Williams's analysis is flawed. Authenticity is never a matter of 'personal intention' for Sartre; it is about taking responsibility for one's choices, and accepting that a man's actions define him, not the reverse ('existence precedes essence'). 'Personal meanings' are not authentic by definition for Sartre. They are just as often post-factum rationalizations of behavior on the basis of an idealized self-image, as with Hugo ('I am politically committed/heterosexual') and paradigmatically, as we shall see, with Garcin in No Exit (1945).

While his analysis is flawed as an account of Sartrean authenticity, Williams's focus on the gap between individual and collective meanings is pertinent. He is noticing a development, in Sartre's work, from the individual experience of freedom to the acknowledgment of common projects and a corresponding tension. Williams (1966) turns briefly to Men without Shadows (1946), written before Dirty Hands, to illustrate the presence of the individual/collective meaning problematic even in the earlier plays: 'Already in Men without Shadows, the essential argument has begun' (1966, pp. 185-186). In the play, a politically committed group of Resistance fighters are captured and tortured; they kill a younger member of their group who was likely to talk under duress, raising questions about who is qualified to judge others. In the end, supposedly in exchange for their freedom, they agree to confess a jointly fabricated version of events. Their jailors believe the lie (the activists' actions were useful to the cause), but they are killed anyway by their cruel and dishonest captor. Williams writes:

In the extremes of exile and despair, the decision has to be taken between a selfjustifying death [i.e. refusing to talk] and the limited actions by which they can still be useful to the cause. They make the decision to be useful, by a common morality, but are killed anyway, by a cruel lie which has all the effect of the wholly arbitrary. (1966, p. 186)

One of Williams's irritations throughout Modern Tragedy is the tendency of the tragic tradition to emphasize the arbitrary nature of suffering, the cause of death or isolation being either blind Fate or malicious caprice, irrelevant to common meanings. In Men without Shadows, a common meaning or ethic is asserted by the characters, but their suffering has no connection to their endeavor or to the movement of history. Williams is perturbed by the way the play's denouement invites a wholly bleak interpretation of events, wherein even tentative 
movements towards collective revolt are coded in terms of an arbitrary and callous universe of empty contingency.

Williams's analysis tracks the development of Sartre's ethical characters from the pure metaphysical rebel (Orestes) through the political assertions of collective meaning in Men without Shadows and Dirty Hands to the active revolutionary (Goetz) in The Devil and the Good Lord (1951 - hereafter TDGL)). In TDGL, Goetz, a military commander and willful mass murderer, loses a bet with a priest and commits to being 'good'. He erects a city of pacifist love, the 'City of the Sun' within a war-torn country (his military genius, meanwhile, is sorely missed at the front) and the city is predictably razed. He eventually abandons his quest for goodness and chooses war. Williams summarizes Goetz's development: 'Goetz comes to see that in a world without God, and in a time of violent social conflict, the important commitment is not to goodness, which is impossible, but to the cause of liberation ... this is the final point of development, from revolt to revolution' (1966, p. 186). In the play, Goetz discovers that in the context of social upheaval, his commitment to abstract goodness was in fact a way of being isolated, a refusal to engage with the common materiality of history. He chooses revolutionary war as a way of 'being with everybody' (Sartre, 1960, p. 149). So yes, there is a movement towards revolution, towards collective action and meaning, a political advance on The Flies, but Williams intends neither a ringing endorsement of Goetz, nor of Sartre's dramatic trajectory. On the contrary, Williams is highly critical of the overwhelming emphasis on revolutionary violence at the expense of what he regards, throughout Modern Tragedy, as the appropriate synthesis of revolution and tragedy, the experiential working through of social disorder. He suspects that, for Sartre, violence means something else:

For Sartre, revolution must be accepted, if any final personal authenticity is to be attained. And if revolution, then political realism and if necessary violence ... Sartre, defending revolution, puts his whole stress on its violence, which at times seems to be not merely necessary but actively purifying. For or against, [both Sartre and Camus] identify historical revolution with a kind of willed violence. (Williams, 1966, p. 187)

Again, Williams is using 'authenticity' oddly; it is perfectly possible, in the Sartrean schema, to be an authentic counter-revolutionary. But he is right to point out, particularly in the case of $T D G L$, that what amounts to 'self-realisation' for many of Sartre's characters is a kind of violent will to power, an existential 'leaning in' to concrete, at their best collective, actions to which it remains intractably difficult to attach firm historical meanings. In part, I think, this is 
because Sartre, at this stage, is deeply suspicious of the social actor who assigns 'respectable' meanings to his actions, like Hugo in Dirty Hands. It is safer to simply act, free from all selfimposed meanings, to refuse to 'code' existence with essence, and to let what objective historical meanings may be established in the fullness of time apply retroactively. In keeping with Williams's critique of liberalism's contradictory metaphysic, we should read this as a secular version of the Christian injunction to forego moral arrogance and await the judgment of God at the end of life.

The commitment to violence, or rather the inability to think through violence to a more meaningful and collective experience of revolution, appears to persist in Sartre's drama, at least, through the conversion to Marxism. Williams completes his survey of Sartre's plays by claiming a basic philosophical similarity between an early and a later work, Huis Clos (No Exit) (1945) and Altona (1960) respectively, drawing a starkly negative conclusion:

If we compare Sartre's early Huis Clos with his most recent Altona, we discover that in the later play a political dimension has been added to the identical (Pirandellian) version of human beings as inevitably mutually destructive and frustrating. It is true that in Altona the destructive and frustrating elements are related to capitalist and to imperialist war, but whether this is a primary or secondary relation we cannot say. If people are as they are in Huis Clos - and nearly all of Sartre's work confirms that this is his view - it is indeed difficult to believe that revolution could be anything more than nihilism. (1966, p. 187)

On the one hand, then, Williams had been tracing a development in Sartre's dramatic characterizations from the pure metaphysical rebel to the active and willful revolutionary. On the other, he detects a countervailing tendency to the progressive development in a basically pessimistic view of human beings in their social relations. Moreover, Sartre's pessimism is not an occasional but a core impulse confirmed by 'nearly all of Sartre's work'. The texts which Williams goes to for evidence are well chosen. Huis Clos (No Exit) contains the famous line 'hell is other people', spoken by the paradigmatically inauthentic Garcin upon realizing that hell is not a place of fire and brimstone, but of eternal proximity to other human beings. The action of the play revolves around the futile attempts of three damned individuals, stuck together in a single room, to evade recrimination by resorting to selfdeceptive ideal-egos, ameliorative fictions which are continually punctured by the barbs of the other detainees. Garcin's starkly pessimistic declaration is an aggrieved railing against authenticity, and a despairing acknowledgment that it is because man is a social animal that he cannot remain protected by his own self-image. 'Other people', the play implies, do not 
have the same interest in rendering your actions respectable, and will often force you to confront the reality that your actions/choices (existence), as opposed to your interpretation of those actions/choices, define your being (essence). In the language of Being and Nothingness (1943), other people are what prevent the human individual from alchemizing itself as poursoi (for-itself: one's conscious self-description) into the more substantive en-soi (in-itself: being).

Williams had noted that in the later Altona, the historical context of capitalist-imperialist war bears only a tangential relation to the mutual frustration of human beings by one another. Again, this is an accurate reading. In the play, set post-WW2, Franz, the eldest son of the Gerlach dynasty of German industrialists, spends his days voluntarily locked in his room, imagining that outside his bricked-up window Germany, having lost the war, lies in ruins. The mystery is why he does so; he appears mad, begging for a future race of 'crabs', the successors to human beings, to judge him. We receive snippets of Franz's troubled backstory, some of which, including sheltering an escaped Jewish concentration camp detainee, imply a deep moral antipathy to Germany's conduct in the war. We eventually learn that Franz is the latest in a long line of inauthentic characters, pretending that his inability to face a 'ruined' Germany was because he had betrayed it. It fact, Franz is incapable of looking upon the real, resurgent Germany out of disgust at its crimes, and guilt at his own complicity in them during his time as a soldier: 'The ruins gave me my justification. I loved our looted houses and our mutilated children. I pretended that I was locking myself up so that I shouldn't witness Germany's agony. It's a lie. I wanted my country to die, and I shut myself up so that I shouldn't be a witness to its resurrection' (Sartre, 1981a, p. 154). Franz's father, whose company provided ships, ports and land for the concentration camps, to the Nazis, apologizes for his role in producing Franz's guilt. The two men achieve a personal détente but, unable to deal with their mutual guilt, they perform a double suicide. Once again, a revelation of authenticity precipitates a bleak, violent dénouement.

Authenticity never 'saves' any of Sartre's characters; it resolves a certain personal deadlock which, regardless, culminates in death or violence of a kind that eschews any sense of transpersonal meaning or historical agency. The rebellion of the metaphysical rebel, even where imagined into a historical context, is never revolutionary in Williams's sense of active, collective involvement. Williams (1966) notes that the kinds of human experience Sartre chooses for his dramatic actions 'are of an overwhelmingly negative kind' (1966, p. 187). 
Sartre's real support for freedom and revolution does not excuse the direction of his dramatic art: 'That he has the courage to believe in freedom, and to support revolution, despite such evidence, is important but again secondary' (p. 187). Williams cannot forgive Sartre the pessimism of his plays because they are predicated on a philosophy the inherent individualism of which not only isolates human experience but, like expressionism, reduces the external (social or natural) world to a system of mechanical laws in contradiction with human needs and interests:

Whether in the bourgeois and bourgeois-Marxist versions of nature as matter to be dominated, or in the existentialist version of nature as indifferent or resistant, there is no sense of common process or common life, and this, itself an analogue of individualism, leads inevitably to despair. In these ways, I see the work of Camus and Sartre as the latest and most notable struggle within the deadlock which has, historically, taken over our consciousness. The conclusions they draw, whether of revolt or revolution, are convincing only to the extent that one's own mind remains within the deadlock itself. (1966, p. 189)

Recalling Williams's general discussion of modern drama, this is the deadlock brought about by the failure of progressive liberalism i.e. the bourgeois revolt against bourgeois society. Liberalism, finding the world which it had made replete with alienation and injustice, attempted to harness its own founding emancipatory gestures to the critique of liberal society. The discursive and political strategies of liberal humanism were sufficiently forceful to emancipate modern society from the pre-existing alienations of a theological/monarchical social order. But that emancipatory promise falls short when confronted by the fresh alienation of an industrialised class society which it can only critique from within a logic of inevitability, since it is the society to which it (liberalism) corresponds. The contemporary enemies of freedom (for Williams, as a socialist humanist, these include both philosophical individualism and real structures of property and power) evade the targeting systems of liberal critique, which turn instead to society in general, to an ahistorical human sociality which 'inexplicably', 'inevitably' reverts to barbarism despite casting off the chains of absolutism.

As stated earlier, tragedy, in the eyes of its conventional theorists, was supposed to have been rendered impossible in modernity because the metaphysical doctrines which undergirded it (Fate, divine caprice etc) had been replaced with the secular doctrines of liberal humanism. ${ }^{66}$ But Williams, having surveyed the existentialist tragedies of Camus and Sartre, cannot

\footnotetext{
${ }^{66}$ Modern Tragedy was in part written in response to a thesis along these lines by George Steiner in his The Death of Tragedy (1961).
} 
concur. His concluding statement on these French dramatists, in which Williams draws a crucial link between Marxism, psychoanalysis and existentialism as quintessential modern doctrines, is worth quoting in full:

It has often been said that tragedy is impossible, in the twentieth century, because our philosophical assumptions are non-tragic. What is then adduced, as evidence, is the humanism of the Enlightenment or perhaps the Renaissance. I have already argued that this is useless; the humanism that matters is not now of those kinds. What is more important to notice is that the three characteristically new systems of thinking, in our own time - Marxism, Freudianism, Existentialism - are all, in their most common forms, tragic. Man can achieve his full life only after violent conflict; man is essentially frustrated, and divided against himself, while he lives in society; man is torn by intolerable contradictions, in a condition of essential absurdity. From these ordinary propositions, and from their combination in so many minds, it is not surprising that so much tragedy has in fact emerged. The tragic humanism of Camus, the tragic commitment of Sartre, are as far as any of us have reached, and each experience, evidently, is of our own time ... But the question remains, inevitably, whether this is really as far as we can go, whether under the weight of a common suffering this is our own last word. (1966, p. 189)

I think this is one of the most crucial passages in all of Williams's theoretical work. Brecht, in the following chapter of Modern Tragedy, will go further than the existentialists. His chapter is called 'A Rejection of Tragedy', and indeed the passage above appears to vacillate between a defence and an assault on the modern tragic impulse. On the one hand, Williams is keen to defend modernity against the charge that its secular humanism renders it non-tragic; as the whole of Modern Tragedy has demonstrated, the tragic impulse is alive and well in new forms. But what these new forms share with the old, and what Williams would like to critique in them, is an essential pessimism about human nature and society, anathema to his own conception of tragedy as the experiential working through of social disorder. For Williams, the modern tragic impulse has been focused through the combined prism of three doctrines, (orthodox) Marxism, psychoanalysis and existentialism. Each of these, argues Williams, postulates an intractable negativity immanent to either human nature or to various intractable structural properties of history/society tout court. In each case, both the problems of social life and their solutions are suspended above human experience and, to a significant degree, human agency. Williams resists these multiple alienations in the name of a new humanism, socialist and materialist, which outperforms the liberal critique of the existing social order by refusing to alienate either problem or solution to a sphere beyond human beings, their common agency and experience. Sartrean drama, even in those moments where it courted history, and even, with Altona, during Sartre's Marxist period, could not achieve 
this, pinned down as it was by the dissident bourgeois structure of feeling which Williams associates with expressionism. For Williams, it was Brecht alone among modern dramatists who occasionally pointed the way forward to a humanist re-historicisation of social transformation, an insistence on the possibility of revolutionary change on human terms.

\section{Beyond Tragedy: Brecht}

In the epilogue to his recent book on the Russian Revolution, China Miéville (2018) offers the following reading of the world's first socialist revolution and its legacy:

The standard of October declares that things changed once, and they might do so again ... Fleetingly, there is a shift towards workers' control of production and the rights of peasants to the land ... And though those moments are snuffed out, reversed, become bleak jokes and memories all too soon, it might have been otherwise. It might have been different, for these were only the first, most faltering steps. The revolutionaries want a new country in a new world, one they cannot see but believe they can build. And they believe that in so doing, the builders will also build themselves anew. (2018, p. 317)

Miéville's is a Brechtian reading of history. The idea that things 'might have been otherwise', that even the past is infused with contingency, is vital to Brecht's project, as is a conception of history as an act of self-making by human beings. Such an anti-mechanical, antiteleological perspective is what Williams is attracted to in Brecht's plays, in which specific historical, or indeed fictional, events are presented as 'case studies' in the contingency of human choice and actions. In this section, we will consider Williams's responses, in Modern Tragedy and Drama from Ibsen to Brecht, to the major plays of the period 1937-1945.

As of the late sixties, Williams regarded Brecht as without parallel among modern dramatists. $\mathrm{He}$ is not only a formally original artist, but a pioneer of a new and progressive manifestation of what Williams called a structure of feeling, that historically specific complex of perceptual, affective and creative responses to social life that functioned as the central epistemological category of Williams's early theory. Williams (1966) emphasizes Brecht's achievement in Modern Tragedy, his last sentence below prefiguring Miéville's Brechtian evocation of the essential contingency of history:

In most modern drama, the best conclusion is: yes, this is how it was. Only an occasional play goes further, with the specific excitement of recognition: yes, this is how it is. Brecht, at his best, reaches out to and touches the necessary next stage: yes, this is how it is, for these reasons, but the action is continually being replayed, and it could be otherwise. (1966, p. 202) 
In the lineage of modern dramatists which Modern Tragedy traces, Brecht comes closest, for Williams, to a perspective approximating a dramatic Marxist humanism. He is not without his limitations, however, and for Williams these are symptomatic of his emerging out of an expressionist tradition inherently predisposed to taking the measure of the individual against society; Brecht falls short, in other words, except in his greatest moments, of a drama of the totality. Nevertheless, via the application of an original theoretical apparatus and dramatic conventions, Williams views Brecht as having achieved a level of social critique which eclipses the metaphysical revolt of the early Sartre and invites further progress.

Contextually, we should acknowledge that Williams's dramatic criticism was in many ways a belated intervention into the Marxist debates around realism and modernism of the thirties, within which Brecht and Lukacs were perhaps the main antagonists. ${ }^{67}$ 'It is remarkable,' Williams (1980) noted in his review of Lukacs's Essays on Realism, 'that so many current arguments, among left writers and commentators, about such fundamental problems as realism, reportage, partisanship and experimental form were prefigured in the lively controversies between socialist writers, especially Russian and German, in the twenties and thirties' (New Society, 1980, Nov 20). Williams's writings on Brecht in the sixties were fundamentally an attempt to enrich the anti-Stalinist humanism of the British New Left, indeed British political and literary criticism more generally, with what Williams saw as a vital strand of European socialist humanist thought.

Before addressing Williams's reading of Brecht's plays in Modern Tragedy and Drama from Ibsen to Brecht, it will be worth briefly recalling the different politico-aesthetic positions, and their attendant formal conventions, which Williams was identifying in his dramatic criticism. Naturalism, Williams argued, was a product of the liberal critique of bourgeois society, an attempt to solidify an object of critique via realistic representations, instead producing an alienated objectivity antithetical to its own humanist aspirations. Expressionism, a product of the failure of the original liberal revolt, escaped inwards, emphasizing the subjective anguish of the bourgeois subject, rejecting conventions aiming at verisimilitude and instead positing an irrevocable gulf between an abstract 'society' or 'external world' and an equally abstracted individual consciousness. Neither was revolutionary; the structures of feeling to which the conventions of both relate are limited to a non-dialectical experience of tragedy. The early Sartre remained at the level of expressionist-subjective revolt, a metaphysical

${ }^{67}$ For an overview of these debates see Theodor Adorno et al, Aesthetics and Politics (2007). 
rebellion which, even when it does rise to meet the real contradictions of revolutionary action (The Devil and the Good Lord), is held at the point of 'willed violence'. Opposed to both the naturalist and expressionist accommodations with the prevailing social order, 'revolutionary romanticism' asserted the necessity of revolution without the negotiation with tragedy (i.e. awareness of contradiction and suffering) which Williams regarded as necessary for revolution to proceed as a 'total process', an authentic experiential working through of social disorder. Sartre had perpetuated the old expressionist structure of feeling; Brecht, for Williams, signaled the emergence of a new experiential paradigm. His dramatic theory and practice offered what Williams saw as the essence of a vital artistic creativity: the communication of new experience to a receptive audience via new conventions developing a common, existing tradition (as expressed in Williams's elaboration of the creative act in $T L R)$. Williams therefore pays considerable attention to the relation between Brecht's theoretical concepts and his theatrical conventions, seeing in them the emergence as dramatic form of a new, proto-revolutionary structure of feeling exemplified in the notion that 'things could be different'. As we shall see, however, Williams still regards Brecht as having fallen short of a 'total' drama or dramatic realism.

In DFIB, Williams argues that by 'Aristotelian' theatre, Brecht meant dramatic naturalism, 'the dominant naturalism of the period after Ibsen' (1983b, p. 317). What Brecht is attacking, Williams contends, "is the central thesis of the "illusion of reality", in which an action is created that is so like life that the verisimilitude absorbs the whole attention of both dramatist and audience' (p. 317). Williams gives some examples of Brecht's opposition between naturalism/Aristotelian drama and epic theatre:

The drama he opposes involves the spectator in a stage-action and consumes his capacity to act; the drama he recommends makes the spectator an observer but awakens his capacity to act ... the drama he opposes presents experience, drawing the spectator inside this until he is experiencing the action with the characters; the drama he recommends presents a view of the world, in which the spectator confronts something and is made to study what he sees ... the drama he opposes takes man, in the run of its action, as known, given, inevitable; the drama he recommends shows man producing himself in the course of the action, and therefore subject to criticism and to change. (1983b, p. 317)

Audience passivity vs. audience activity, immersion vs. critique, man as reified and given vs. man as self-producing contingency. The latter terms of each opposition approximate the axioms of a broad humanism, but Williams is also happy to ascribe to Brecht's practice a Marxist foundation: 
Essentially, what Brecht created, after long experiment, was a dramatic form in which men were shown in the process of producing themselves and their situations. This is, at root, a dialectical form, drawing directly on a Marxist theory of history in which, within given limits, man makes himself. (1983b, p. 318)

Williams deepens the reading of Brecht as Marxist by contrasting his approach to 'naturalist materialism': 'Correspondingly, the pure naturalist form ... depends on a simpler materialist view, in which man discovers the truth about himself by discovering his real environment: the literal presentation of this environment is then a means to human truth' (p. 318). Brecht, argues Williams, manages to avoid the naturalist temptation to explain man entirely in terms of his environment; he refuses the ahistorical abstraction of human nature and the liberalhumanist variant of mechanical materialism (in which the determining role of God is displaced onto Nature). In other words, Brecht aims at, and occasionally produces, a nonalienated objectivity, an objectivity suited to the goals of a 'Marxist humanism'. Recall that it was precisely on the grounds of its elaboration of an alienated objectivity that Williams rejected orthodox Marxism (mechanical materialism), including Lukacs's subtler formulation.

Both DFIB and Modern Tragedy assert the superiority of Brecht's output between 1937 and 1945 to earlier efforts. In The Threepenny Opera (1928), The Measures Taken (1930), St Joan of the Stockyards (1931) and the slightly later Fear and Misery in the Third Reich (1938), Williams views Brecht as groping towards, but ultimately failing to achieve, the dramatic realization of his central theoretical categories, in particular the notions of 'making strange' (Verfremdung/Entfremdung - also 'alienation/distancing effects') ${ }^{68}$ and 'complex seeing'. It was only, Williams argues in DFIB, 'in the major plays, from 1937 to 1945, that Brecht broke through to a complex seeing which was the dramatic action itself' $(1983, \mathrm{p}$. 323). The four major plays which Williams discusses in this context are The Life of Galileo (1938), Mother Courage and her Children (1939), The Good Person of Szechuan (1941) and The Caucasian Chalk Circle (1945).

Williams's account of The Threepenny Opera will suffice in elaborating his critique of the earlier plays. The broad point is that an 'objective-critical' position, which Williams saw as being at the heart of Brecht's mature drama, is incompletely realized when the advance in consciousness which declares 'this is how it is' is not followed with the assertion that 'things

\footnotetext{
${ }^{68}$ For Brecht's own formulations of these concepts, see Bertolt Brecht, Brecht on Theatre: The Development of an Aesthetic (1997).
} 
could be otherwise', i.e. when the critical charge remains at the level of naturalist or expressionist critique and resignation. Williams reads The Threepenny Opera, an ironic farce in which the amorality of criminals, whores and corrupt officials acts as a metaphor for the endemic immorality of bourgeois society, as aiming at the defamiliarization of bourgeois society for the audience by inserting its own ideology of respectability into a down-and-out, criminal milieu: 'The Threepenny Opera, for example, is offered or rationalized as a portrait of respectable bourgeois society. If all property is theft, and the institutions of property cold and false, then thieves and whores are the true if shocking portraits of a society trying to pass itself off as respectable' (1966, p. 192). The inevitable result of this attempt, argues Williams, is failure. 'Nothing is more predictable', says Williams, 'in a falsely respectable society, than the conscious enjoyment of a controlled and distanced low life ... There is no real shock, when respectable playgoers confront it, because [it is] seen, precisely, as a special class, a district' (p. 192). Brecht's early attempt at a drama of 'complex seeing', in which the audience should be invited to critique 'what is' in the name of 'what could be', ends up ratifying the existing order; endemic immorality is relegated to a district which is in any case disavowed by bourgeois morality. The result is an incomplete synthesis between theory, formal convention and the structure of feeling Brecht latterly expressed. Williams expresses this as follows:

Brecht had found his theory, in the idea of complex seeing, but its practice was not there, in the actual play ... He had used distancing effects to push the spectator into 'what the spectator wishes to see': crime and coldness not structural in the society, but lived out in a romantic and theatrical district ... Brecht thought he was detaching himself ... by a calling it bourgeois morality, but in The Threepenny Opera this is so external, so really casual, that it is in effect an indulgence. The displacement of feelings about modern capitalism on to a group of pseudo-eighteenth century thieves and whores is no more than an escape clause. (1966, pp. 193-195)

Williams (1983b) acknowledges that Brecht recognised his error, and that in his later plays complex seeing was integrated into the dramatic action, rather than appearing as an 'imputed' attitude of a newly 'enlightened' audience: 'The spectator (as Brecht learned, bitterly, when his Threepenny Opera succeeded for what to him were the wrong reasons) is the one element the dramatist cannot control, in any form. It is in the action, the dramatic design, that the choices Brecht insists upon must be made' (1983b, p. 318). This, of course, was precisely Williams's critique of Lukacs's notion that good realist fiction should transparently demonstrate the totality of an unjust social order, and that provided this was achieved the reader would necessarily become possessed of her imputed class consciousness. Williams's 
critique of Brecht places the full burden of stimulating the audience to critical thought on the skill of the dramatist. The 'epic' dramatist, for the later Brecht and for Williams, should provoke the critical faculties of the audience by defamiliarizing the dominant ideology and presenting the staged action as radically contingent and dependent upon human action within a given context.

Williams views Brecht's later plays as the synthesis of his dramatic theory with his dramatic form. 'The extraordinary thing about Brecht', says Williams, 'is that he was able to grow through this position ... into the genuine complexity: the connections and contradictions between individual goodness and social action' (1966, p. 196). Naturalism and expressionism were, of course, concerned with the relation between the individual and society, and here Williams praises Brecht for approaching this in an unusually subtle manner. The later plays do not, like the earlier, rely on a direct transfer of 'true' consciousness from dramatist to audience via a univocal unmasking of bourgeois ideology. Rather, the dramatic action itself expresses the possibility of multiple interpretations, and the audience is invited to interact with the material critically on this basis. 'It was in the major plays, from 1937 to 1945', Williams (1983b) argues, 'that Brecht broke through to a complex seeing which was the dramatic action itself' (1983b, p. 323 - my emphasis).

The most explicit example of Brecht's later method is, for Williams, The Good Person of Szechuan. In the play, the destitute prostitute Shen Te is granted a sum of money by gods who wish to find a good person on Earth. She sets up a tobacco shop but is immediately beset by problems stemming from the needs of others in a brutal, commercial society. Unable to resolve the contradiction between personal morality and social immorality in herself, she devises an alter-ego, Shui Ta, a male 'cousin' who occasionally appears and, by practicing a tough, utilitarian self-interest, protects Shen Te's personal prosperity by immoral means. The epilogue, the play having refused to pass verdict on the contradictory life of Shen Te/Shui Ta, challenges the audience to make up their own mind: 'There's only one solution that we know / That you should now consider as you go / What sort of measures you would recommend / To help good people to a happy end / Ladies and gentlemen, in you we trust: / There must be happy endings, must, must, must!' (Brecht, 1998, p. 111). At the most basic level, the play evokes the usual naturalist-expressionist incompatibility between the aspirations of the individual and the frustrations of the prevailing social order. But Williams sees Brecht's version as avoiding the temptation to submit to commonplace versions of this liberal-critical 
doxa, whether in 'the romantic figure of the isolated heroine destroyed by the greed of others' (1983b, p. 323) or 'the anti-romantic version, in which the woman, realizing that her society was like this, [would adopt] a cheerful, tough amoralism - "eats first, morals after" - and [keep] alive' (p. 323). Both of these would be examples of 'simple seeing' (p. 323), argues Williams, monologic exercises in accepting, or critiquing and then accepting, the hegemonic order. Brecht, says Williams, incorporates both archetypes into a single consciousness and a single objective action, achieving complex seeing:

But what Brecht now does is in effect to embody both versions: Shen Te, the good woman, invents her tough cousin, Shui Ta - first as an alternative, relieving role, but then, in effect, as an independent person who coexists with her. It is not fixed goodness against fixed badness - a cops-and-robbers morality - but goodness and badness in the act of being produced in the turns of an action, as coexistent possibilities. This is genuinely complex seeing, and it is deeply integrated with the dramatic form. (1983b, p. 323)

In opposition to the traditional expressionist method of showing contradictions in their subjective aspect, occurring within a single mind, the contradictions which The Good Person emphasises are shown 'through an objective action in which Shen Te and Shui Ta are at once created characters and yet, by this fact of creation, reveal the processes by which they have produced themselves' (p. 323). This is only possible, Williams argues in Modern Tragedy, because 'No resolution is imposed. The tension is there to the end, and we are formally invited to consider it' (1966, p. 197). The lack of explicit ideological positioning permits, in epic style, 'impersonal judgement' (p. 198) on the part of the audience, negating both the tendency to audience passivity of earlier forms and the pseudo-Lukacsian aspiration to 'imputation' that marred The Threepenny Opera.

It is demonstrative of Williams's conception of art as the expression of a structure of feeling rather than as formal conventions in abstraction that he regards The Good Person as both the clearest expression of epic convention (complex seeing) and as less than 'a full dramatic discovery' (1983b, p. 324). In DFIB, Williams groups the four major plays under discussion into two pairs, the 'fable plays' and the 'history plays'; The Good Person and The Caucasian Chalk Circle fall into the first pairing, Mother Courage and Galileo into the second. In the fable plays, says Williams, 'the issues are characteristically simpler' (p. 324). Scenarios are created as cases for direct debate and judgement by the audience, which Williams regards as 'the simplest, most discursive version of complex seeing' (p. 324). The fable-plays, Williams's analysis suggests, are in an important sense ahistorical; they are set in given 
historical periods and regions, but do not engage history as a motive force in constructing the social context within which characters make their choices. Fables, of course, are meant to be universally applicable, and by this choice of form, Williams argues, Brecht simplifies the full complexity of these scenarios. Williams notes that, in The Caucasian Chalk Circle, a play in which the clownish, vitalist figure of Azdak becomes the real arbiter of justice in a case of disputed maternity between a cruel aristocrat (the biological mother) and a criminalised peasant (who raised and loves the child), the fable form facilitates complex seeing at the same time as it displaces history:

The main dramatic conclusion, through the figure of Azdak, is arrived at almost by impulse: an essentially unpredictable vitality, concerned, really, with neither formal law nor human morality, gives the child to the woman who loves her, in 'a brief Golden Age that was almost just'. That is indeed how it could happen, in the fable plays: life would find the right way, as in all fable conventions. The intellectual backing, that life finds the right way through the struggles of history, can be produced on demand, but, in creative terms, is only marginally present. Thus, though formally the seeing is complex, the chosen action is a simplification. (1983b, p. 325)

Even the mature Brecht, it seems, at least in the fable plays, slips into something like abstraction or formalism. The distinction which Williams is drawing between the fable and the history plays is more than a formal comparison. It relates, crucially, to his assertion that Brecht is dealing with a new structure of feeling, and that his conventions are only fully successful when they relate directly to this. Recall that a structure of feeling is really a social experience; the communication involved in successful art is not of objective knowledge, but of this experience. It is in their disconnect from this experiential epistemology that Williams sees the partial failure of the fable plays: they do not communicate experience so much as dramatize the objective-critical mode of thinking itself. Another way of putting this would be to say that it is impossible to engage the audience in a structure of feeling, in the communication of real experience, via what is ultimately the portrayal in art of a critical methodology. Experience has to be conveyed in a different way, and it is this feat that Williams sees Brecht's history plays as better accomplishing.

The key virtue of the history plays is their insertion of a sense of historical process into the conventional Brechtian 'case study'. This combination of history and contingency is, for Williams, the true locus of Brecht's achievement (it is also, of course, the locus of totality). Williams (1966) is particularly effusive in his praise of Mother Courage: 
To call this action Shakespearean is not to put the praise too high. History and people come alive on the stage, leaping past the isolated and virtually static action that we have got used to in most modern theatre. The drama simultaneously occurs and is seen. It is not 'take the case of this woman' but 'see and consider what happens to these people'. (1966, p. 198)

The difference is between 'taking the case' and 'seeing what happens to these people' may not be immediately apparent. The crucial phrase is these people; specific people, in a specific historical moment, faced with specific contradictions embedded in a concrete social structure. The point is not, as was partly the case with The Good Person, to establish whether or not characters are making the 'right' moral choices: 'That separable moral judgement is precisely what the play confounds. For not an attitude but an experience drives through the action: what else can be done, here, in this war across Europe?' (Williams, 1983b, p. 327). Mother Courage, like the other three major plays, eschews a contemporary setting, but unlike the others its action (the travails of a destitute family in the war-torn Europe of the Thirty Years War) is immediately translatable into Brecht's and his audience's common experience of war. A link is thus forged between the dramatic action, the convention of complex seeing (encouraging an objective-critical attitude) and a resonant historical experience capable of engaging the audience with the Brechtian structure of feeling. What exactly that structure of feeling amounts to is then the crucial question.

The action of Mother Courage revolves around the absolute contradiction, in a violent class society, between the imperative to acquire money as the means of subsistence, and the imperative to directly preserve life. Both are matters of life and death and are, in concrete historical circumstances, mutually exclusive; the preservation of life in one moment can lead to death in the next. Mother Courage herself is repeatedly required to make such decisions and, by the close of the play, her children have all been killed. It is worth quoting Williams's (1983) commentary at length:

Past the justifications, the excuses, the 'bad luck', the inevitabilities, it takes this action - of a mother destroying her family with the aim of preserving life - to see what is happening; to be able to bear to see it. If she were not so strong and persistent, there would be no life at all; and at the same time, because she is strong and persistent, in a destructive society, she destroys the life that she has herself has created. This deep and complex image, in a character and in an action, is Brecht's central structure of feeling, directly dramatized. It is by looking at this action, this character, in the face, that we see what we are doing: the essential contradiction; the destructive acquiescence in the name of life; the persistent vitality in a continuing destruction ... The conflict is pushed through, seen from every side, until it connects with our own conflict. (1983b, p. 328) 
How does this differ from the traditional naturalist-expressionist structure of feeling, in which an individual lives an impossible life at the hands of an irrecoverably unjust society? The difference is that Mother Courage tries, consistently, with 'courage', to preserve life; she does not revert to ironic acceptance of corruption like the characters of the Threepenny Opera, engage in duplicity or self-deception like Shen Te, or in any way pretend that her choices are not her own. She is aware of social injustice, but also that her decisions carry weight, and are her own even when enacted under the overwhelming pressure of a violent social order. What Williams does not say, but which his analysis strongly implies, is that Mother Courage is acting authentically in the Sartrean sense, refusing to attribute her actions to external energies which force her hand despite an 'inner' goodness. Unlike in Sartre's plays, however, the assumption of responsibility by characters is not followed by an act of arbitrary violence; Mother Courage carries on, as a living character in a violent society, making painful decisions in an overall historical context she cannot personally control. Moreover, her actions are not causally superfluous. At least two of her children die as direct consequences of her decisions; she alters the social world she is living in. The point is not that an inert society and/or human nature presents us with impossible decisions or an unliveable life, but that human beings can produce suffering and destruction through their very attempts to supersede it or to mitigate the effects of social disorder. The suicides and arbitrary deaths of Sartre's plays fail to speak to this constitutive, painful human involvement in history. For Williams (1966), the image of Mother Courage struggling on with her cart through a concrete historical world, making decisions and living with them, is 'a way of looking at a continual action' (1966, p. 199), the real, frequently sad, continuous action of history as both 'lived in' and 'made'. Tragedy is not inevitable, in this model, but history is often tragic.

Where Mother Courage was about a particular kind of degraded but active life embedded in history, Galileo concerns human decisions of larger historical significance. The action revolves around Galileo, who has discovered the true movement of the spheres, and his tortured decision to renounce his discoveries under theocratic persecution. At the end we discover that Galileo, while under 'house arrest' by the Church for many years, has secretly been completing his radical Discorsi; the play closes with the text being smuggled over the border into freedom. In the penultimate scene Andrea, a friend of Galileo's, interprets his actions as an honourable rebellion against the Church in the name of science. Galileo disagrees, claiming that he recanted to avoid torture and insisting that he has done a great disservice to the scientific community. In his final speech of the play, Galileo makes clear his 
view that he has betrayed not only science, but also his fellow man, since his actions have ensured that the social function of science will be to bolster the power of an elite at the expense of a superstitious and exploited population:

If the scientists, brought to heel by self-interested rulers, limit themselves to piling up knowledge for knowledge's sake, then science can be crippled and your new machines will lead to nothing but new impositions. You may in due course discover all that there is to discover, and your progress will nonetheless be nothing but a progress away from mankind. The gap between you and it may one day become so wide that your cry of triumph at some new achievement will be echoed by a universal cry of horror. (Brecht, 2006, pp. 108-109)

Galileo loses his public connection to the truth, and with it disconnects the public from that truth, and from the social goods that stem from the democratization of knowledge; as Williams puts it, Galileo 'loses the connection of his truth, his science, with the needs - the physical continuities and satisfaction - of the majority of men' (1983, p. 328). In the final scene, as the text crosses the border, some small boys speak credulously of witches; they remain in the world of superstition which Galileo's decision has helped perpetuate. In this composite image, Williams's argues, contradiction is retained and left unresolved as a constitutive force in history:

When the manuscript crosses the border, it is hidden in a coach, and the boys playing at the frontier - the boys who would have been Galileo's audience - are talking of devils and witches. Both things happen: a way of continuing science, and a way of detaching it from ordinary life. And the solution is in the service of Galileo's ordinary life: the goose and the opportunity to work, both of which he had every right to. A complex consciousness, in which not only this but also that must be said, is then brilliantly created. (1983b, p. 329)

The creation of a 'complex consciousness', replete with contradictory impulses neither entirely honest nor entirely self-justifying, responding to and altering an objective context; this, for Williams, is the method of properly historical characterisation. It is also a way of inoculating a piece of narrative art from pseudo-idealism of the Lukacsian-Sartrean variety, the temptation to think that if only the right things were known or admitted, a positive outcome would be reached. Simple awareness of class interests or individual freedom is not a sufficient guarantor of radicalisation. Williams felt that Brecht's mature drama offered a superior conceptualisation of the radical impulse to change things, as well as the experience of suffering associated both with life as presently lived and with the conflictual process of social revolution. 
At the core of Williams's generally positive appraisal of Brecht in Modern Tragedy is the idea that the playwright is breaking with the tragic tradition by incorporating history and contingent human decision-making into his dramatic actions, rejecting tragedy as an inevitable, reified fact: 'The major achievement of Brecht's mature work is this recovery of history as a dimension for tragedy' (1966, p. 202). The Brechtian structure of feeling is precisely this refusal of tragedy as synonymous with the human condition, an affective complex which actively and self-consciously rejects the notion that things cannot be otherwise. The tragic feeling in Brecht is the feeling that the suffering borne by his characters is a contingent fact, and therefore avoidable, but also that, for concrete reasons, it is not avoided in numerous cases. From this mode of consciousness, Williams argues, commitment to a different future may follow.

This feeling extends into a general position: the new tragic consciousness of all those who, appalled by the present, are for this reason firmly committed to a different future: to the struggle against suffering learned in suffering: a total exposure which is also a total investment. Under the weight of failure, in tragedy that could have been avoided but was not avoided, this structure of feeling is now struggling to be formed. (1966, p. 203)

Tragedy, here, is not an affliction, but an aspect of history. History, for its part, is not an alienating process but that which human beings produce in their activity, and could produce differently; this is the achievement of Brecht as a historical materialist. But if Williams regards Brecht as at least in part unravelling the knot of historical alienation, establishing the negative liberty of history (freedom from alienation), it is equally clear that Williams sees Brecht as failing to provide a positive emancipatory project; the freedom to produce history, the means to do so, is lacking. I turn now, in concluding, to Williams's discussion of the limitations of Brecht's approach, and his insistence on the necessity of moving beyond it.

Williams touches on the possible pitfalls of the Brechtian structure of feeling in Modern Tragedy; these are fleshed out with a different emphasis in DFIB. In the former text, Williams's partial critique of Brecht is centered on the idea of historical fixity through resignation. Danger arises when 'not the recognition but the acceptance of contradiction' (1966, p. 203) is the predominant attitude towards the basic Brechtian acknowledgement that humans beings often produce suffering in their attempts to go beyond it; recognition is the goal, resignation and acceptance the pitfalls. The final paragraph of Modern Tragedy (also the very end of the Brecht chapter) expounds on this risk in broad strokes, relating it at all times to the difference between fixation and abstraction on the one hand, and the real, 
experiential working through of social disorder on the other; it is also linked to the concrete historical example of the Soviet Union. This is worth quoting at length:

The recognition is a matter of history, the known harshness of the revolutionary struggle. But while this is seen as a process it can be lived through, resolved, changed. Whereas if it is seen, even briefly, as a fixed position - an abstract condition of man or revolution - it becomes a new alienation, an exposure stopped short of involvement, a tragedy halted and generalized at the shock of catastrophe. In our own day, in a known complexity, it is the fixed harshness of a revolutionary regime which has turned to arrest the revolution itself. (1966, p. 203-204)

Resignation, then, breeds abstraction, and is the antithesis of humanist 'involvement'. Where suffering in the process of cleaving to something better is viewed as a perennial feature of the human condition, the critique of capitalism becomes 'a new alienation', the alienation of man from history, the revolutionary process 'stopped short of involvement'. Moreover, this is not the overwriting of revolution by tragedy, but 'a tragedy halted', tragedy itself, as a dialectical counterpart to the real process of revolution, abstracted into an external force which suffuses man. That Williams brings his discussion round to the Soviet Union should not distract us from the fact that this is the conclusion Modern Tragedy brings to bear on Brecht; the danger of fixity, of acceptance, are dangers shared by real revolutionary movements (which, by 'halting tragedy', breed counter-revolution), and by Brecht himself and us as readers encountering his work. In this absolute opposition to fixity, Williams prefigures his later formulation of the residual, dominant and emergent strains in a structure of feeling; indeed, we may venture to read this tripartite process not just as a factual description of the way cultures develop, but also as a normative statement of how cultures should develop, continually, if they are to resist the counter-revolutionary pressures of fixity and abstraction.

The critical historical analogy in Modern Tragedy is, it must be said, a little cryptic. We can better discern the connections Williams is making by turning to the more precise account of Brecht's limitations in DFIB. In his concluding remarks in that text, Williams argues that while Brecht does more to develop the expressionist mode than any other dramatist, he is still ultimately of that tradition and, crucially, still cleaves to the binary individual/society:

Put one way, Brecht's drama is that of isolated and separated individuals, and of their connections, in that capacity, with a total historical process. He is hardly interested at all in intermediate relationships, in that whole complex of experience, at once personal and social, between the poles of the separated individual and the totally realized society. His dramatic form, isolating and dialectic, serves this structure of feeling exactly. (1983b, p. 331) 
Another way of putting Williams's claim that Brecht neglects 'intermediate relationships', of course, would be that Brecht neglects class; we might then argue that this condemns Brecht's drama to a limited apprehension of the movement of social forces so vital to a perspective capable of overcoming fixity (Brecht's characters, it should be acknowledged, are distinctly classed). Williams, however, in a move which signals his proximity to Lukacs on the issue of reification and totality, declines a straight class analysis and focuses, as in his treatment of realism, on the opposition between a conception of the totality and the reified polarization of the individual and society. The lack, in Brecht, of a sense of how to move through suffering to a new state of affairs is then formulated in terms of his continuation of this binary; collective action, social revolution as the whole movement of the totality, is foreclosed or left unexplored. We might say that Williams views Brecht's drama as dialectical but isolating; it insists on the possibility of change while retaining the isolation of individuals who, precisely because of this, are not aligned with a trajectory of transformation.

What in $M T$ had been the risk of abstraction and fixity has become, by DFIB, Brecht's actual fate. Williams describes Brecht's ultimate inability to overcome fixity as follows:

Because the polar relationship is still there and decisive, the drama is retrospective, in a deep sense: the intolerable isolation is a fact, and when we see men producing themselves and their situation it is this, essentially, that they produce; that it is seen as inevitable and yet is rejected. The dramatic form is not oriented to growth: the experiences of transforming relationship and of social change are not included, and the tone and the conventions follow from this: men are shown why they are isolated, why they defeat themselves, why they smell of defeat and its few isolated, complicit virtues. (1983b, p. 331)

Men are shown why they suffer in a humanist manner which refuses the cynical arbitration of external abstractions, but they are not shown how to proceed, or even given an indication of the processes involved in social transformation. This, for Williams, is a fatal limitation, but it does not take away from Brecht's 'major originality' (p. 331), which is that his drama thoroughly rejects the world of defeat, frustration and absurdity accepted by the naturalists and earlier expressionists, 'a world purged now, by Brecht, of pity and acceptance - held at arm's length, criticized, explained' (p. 332). Brecht's critique is not only a moral one, that things ought to be different, but also metaphysical one, that things can be different, because social causality is the remit of human beings in society. Brecht's achievement is to fully illuminate the dramatic world of naturalism and expressionism, which is a reified world, to be fully aware of all the implications of a world based on the opposition between the individual 
and society. At the same time, Brecht is still 'of' that world; he does not achieve a drama of the totality, but rather a kind of self-conscious reification, the furthest point that a reified drama can develop before changing into something else.

Brecht's work, in Williams's (1983b) view, is a kind of postscript to the modern dramatic tradition, its hard limit, which must now be the ground of a new structure of feeling, and a new dramatic world:

The power of this different master is conclusive. With this last shift, a particular dramatic world - that of the individual against society - is now wholly seen. Without the substance created by others, Brecht's critical epilogue - his dramatic negative could not have been written. But now that it has been written, in two or three great plays and in a wider achievement of a powerful and unforgettable dramatic consciousness, we have to struggle to enter, as Brecht himself insisted, a new kind of world. (1983b, p. 332)

Brecht, in short, has opened up the possibility of change. How to bring about that change is then the salient question, as is how to do so in such a way that tragedy and revolution are viewed dialectically, as the experiential and cultural 'working though' of social disorder. It is clear that Williams regarded Brecht's inability to envision that kind of progress as a function of his isolating retention of the individual/society binary and unwillingness to investigate 'intermediate' social groupings. In the extract from China Miéville with which I opened this section, we are met with a Brechtian endorsement of possibility but in a social action populated by specific people: the workers or, later, the 'builders'. Brecht's drama was by no means classless, but neither did it portray the proletariat as the exclusive agent of historical change. Williams also eschews the traditional Marxist model, preferring the more expansive and inclusive emphasis on culture itself, the totality of a way of life (with subject and object mutually determining one another), as that which powers and undergoes social transformation. What Williams is doing then, as his own way of attempting to 'go beyond' Brecht, is recapitulating his central stance that the project of overcoming fixity, the wallowing in tragic social disorder, will not be realized by the emancipation of an isolated individual who in any case does not exist.

We might characterize the challenge of a Marxist humanism as being to overcome the condition which Fromm, to whom Williams's analysis of the individual and society in TLR was indebted, attributed to modern man in his The Fear of Freedom (1942): a feeling of insignificance and powerlessness resulting from the tension between a liberal, positive freedom from social bonds and the insecurity and uncertainty which this very freedom 
engenders. 'Society' comes to appear not as a constitutive force in one's development, but as an alien force or collection of 'others' to which one must somehow relate through 'social contracts' and other means. Liberal or bourgeois ideology, of course, erects itself upon this conception of the human being. Williams's theory of tragedy, as well as his critical assessment of various 'tragic' traditions and conceptions, is both an acknowledgement of this 'liberal condition' and a call for its theoretical and political negation. The means of doing so, of course, was the perspective of totality, the production of an altered understanding of man's position in the world that relates him inseparably to a social and material world while retaining the individual human being as the centre of political and moral concern. Let us now, in tracing Williams's response to Sartre's transition to Marxism and the Critique, enquire of both: is individuality still a meaningful concept in a world defined by totality? Over the next two sections, I read Williams's writings on individual freedom by the light of his responses to Sartre's, both in his existentialist and his Marxist phases. We will find that Williams's estimation of Sartre on these issues increases as we move from the tendentially liberal and voluntarist existentialist writings, from which the 'metaphysical rebel' of the plays proceeds, to the properly dialectical analysis of the Critique, which both influenced and confirmed the totalising methodology of Williams's social and aesthetic theory.

\section{Williams, Sartre and Liberal Ideology}

Williams begins his discussion of the individual and society in TLR with an etymological analysis, prefiguring the methodology of Keywords. He draws our attention to the medieval roots of the word 'individual' as closer to 'inseparable', being involved in theological debates over the status of the separate aspects of the Holy Trinity, 'how a being could be thought of as existing in its own nature yet existing by this nature as part of an indivisible whole' (2011b [1961], p. 96). The notion then moves through Reformation conceptualizations of the 'individual soul' and 'a man's individual relationship with God' (p. 97) towards application to a person's social position; men become capable of seeing themselves as 'having' rather than 'being' their social position, to choose or move between positions and to develop affective links to 'being an individual in a sense separable from one's social role' (p. 98). Williams's analysis here is ideological-linguistic, but patently non-idealist; he is at pains to stress the formative role of material historical and social change to the development of the ideas concerned. In particular, he emphasizes the historical roots of what would become bourgeois ideology: 
The growth of capitalism, and the great social changes associated with it, encouraged certain men to see 'the individual' as a source of economic activity, by his 'free enterprise'. It was less a matter of performing a certain function within a fixed order than of initiating certain kinds of activity, choosing particular directions. The social and geographical mobility to which in some cases then changes gave rise led to a redefinition of the individual - "what I am" - by extension to "what I want to be" and "what by my own efforts I have become." (2011b [1961], p. 98)

What Williams does not do is explicitly link the emergence of liberal ideology to the rise of the capitalist class. The historical analysis evokes the passage to modernity rather than the transition to bourgeois rule: 'Thus we can trace our concept of 'the individual' to that complex of change which we analyse in its separable aspects as the Renaissance, the Reformation, the beginnings of the capitalist economy' (p. 99). Williams views the development of the modern 'abstraction of the individual from the complex of relationships' (p. 99) as a general pattern of response to changing real conditions; the emergence of ideological and philosophical liberalism is an intellectual intensification of that pattern, rather than a reflection of ideological dominance on the newly dominant class.

In English thought, Williams argues, a pattern develops through Hobbes, utilitarianism and Locke, within which, in contrast to the foundational organicism of former systems, 'individual man is the axiom, and society the derivative' (2011b [1961], p. 100). This abstraction of the individual, the conception of it as something which pre-dates society and which society is codified around and in the service of, is a severe limitation in producing convincing social analyses. The major success of liberalism, however, is in something not dissimilar to the Brechtian emphasis: that things can be different and that a person can be to some degree self-making. Building on social-psychological theories of 'individuation', Williams's formulates a tentative (and rather imprecise) definition of 'individuality' that combines an acknowledgment of the unique potentialities and histories of each person with the strong effects of social influence and partial determination and capacities for selfdirection attendant on self-consciousness: "This "autonomous" self grows within a social process which radically influences it, but the degree of gained autonomy makes possible the observed next stage, in which the individual can help to change or modify the social process that has influenced and is influencing him' (p. 107). Here Williams is groping towards what he will, in the later essays on artistic freedom, call 'alignment and formation', a basic embeddedness in social relations and the lasting formative influence of one's personal and 
social history, in negotiation with art, however 'unconstrained' by other factors, is necessarily produced. In the 'Individual' entry in Keywords, Williams would make a clarifying distinction between 'individualism', the liberal inscription of the rights of a 'given' or preexisting abstract individual, and this version of 'individuality', which 'comes out of the complex of meanings in which "individual" developed, stressing both a unique person and his (indivisible) membership of a group' (2014, p. 161), in effect restoring to the word a measure of its organicist origins.

In the 'Images of Society' section of $T L R$, Williams more explicitly connects individualism (the abstract cousin of individuality) to bourgeois liberalism or 'economic individualism' (2011b, p. 131). 'Here', says Williams, 'instead of thinking of society as an established order, you think of it, essentially, as a market ... You do not now start from the King or the established social order: you start from the activities of production and trading, and increasingly these are seen as the essential purposes of the society, in terms of which other activities must submit to be judged' (p. 131). This ideological saturation accelerates as does the development of capitalist social relations: 'With the further development of capitalism, to its corporate stage, society was no longer thought of as merely providing a market: the organisation of society itself was essentially a market organisation ... Obligation and service had been challenged by freedom and responsibility, but then, in the final image, buying and selling became terms in which all human activity could be assessed' (pp. 131-132). Again, the direct Marxist attribution of these changes to shifts in class power is absent; the new individualist ideology militates in favour of markets and market relations, but these are seen as an overarching condition, a material generality producing a set of changing ideological responses. This harnessing of the abstract conception of the individual to the maintenance and justification of a market society was, recalling the discussion of Lukacs, what Williams had understood by reification: the pattern of material developments produces a pattern of response which is inadequately totalising, distorting the real dialectical indivisibility of individual and society. Williams's critique of classical liberal ideology in TLR is clearly a measured one. In the general assessment of liberalism above, Williams views the positive element as the liberation of human beings from 'arbitrary and oppressive systems'; the negative element is not intrinsically linked to the market, nor to the interests of that rising class whose interests liberalism in fact announced and legitimised, but is tied instead to the inability of liberalism to adapt to changing circumstances, in particular the development of its own intensifying contradictions, including the prevalence of market relations. As elsewhere 
in $T L R$, class is present but implicit, perceptible beneath the surface of a trenchantly universalizing argument that stresses the development of general ideological tendencies in a shifting and contradictory, but fundamentally shared cultural formation. The breakdown of that formation and its ideology is then the salient issue.

The title of Modern Tragedy finally refers, I think, to precisely that breakdown of liberal consciousness which issues in the irrationalism of expressionism and the total disassociation of the individual from society. It is important to always bear in mind that, for Williams, this is the breakdown of an emancipatory impulse, its fixation (as we saw in the discussion of Brecht) in counter-revolutionary forms. At the core of Williams's analysis across TLR and $M T$ is an account of two interrelated necessary conditions for a sustainable emancipatory movement: a) the commitment to openness and change (inoculation against fixation) and b) an awareness of the totality as the dialectical interrelation of individual and society. One way of framing Williams's argument in these two sixties texts is that liberalism achieves a) but not b); it asserts, as did Brecht, the necessity of change and the irreducibility of human beings to roles within a fixed order, but it builds this critique of absolute order from a reified foundation, the autonomy of the pre-existing atomised individual. It is this, essentially, that renders liberalism a failed project for Williams. In Modern Tragedy that failure is theorized as an inability to make the decisive choice to embrace socialism and the socialist idea of revolution, which is fundamentally the choice between a reified and a total conception of human freedom:

The liberal idea of revolution and the feudal idea of tragedy are no longer the only alternatives, and to go on offering to choose between them is to be merely stranded in time ... It is at first sight surprising that so open and positive a movement as liberalism should ever have produced tragedy at all. Yet each of the literary movements which took their origins from liberalism came to a point where the most decisive choices were necessary, and where, while some chose, others merely divided. (1966, p. 68)

The 'feudal idea of tragedy' was the inescapability of the absolute order, given agency in the figure of Fate; liberalism diffuses this with its emphasis on contingency and the malleability of rank, but in cleaving to this option we remain mired in the reification of the individual, from which perspective social revolution, as opposed to the desperate, violent individual rebellions we found in Sartrean drama appears impossible. 'Socialism, I believe,' says Williams at the end of the section on liberalism, 'is the true and active inheritor of the 
impulse to human liberation which has previously taken so many forms' (p. 74). For Williams in Modern Tragedy, the acceptance of totality is the acceptance of a socialist form of revolution, one which views tragedy not through the prism of the abstract individual oppressed by an abstract society, but as the dialectical synthesis of suffering and liberation through which means alone social disorder may be overcome. But this means discarding a particular, received notion of liberty, and making the active decision to embrace a new consciousness of what freedom and unfreedom might mean in a modern, capitalist society. This conception of revolutionary consciousness recurs in Williams's claim in 'Art: Freedom as Duty', that the only duty of the writer is to move through the temptation to replicate the emancipatory slogans and rhetorical flourishes of an available tradition: to 'hold yourself at that point as a writer ... with some hope of moving beyond it' (1978, p. 94). Here freedom is the combination of the negative liberty of artistic freedom itself (the absence of an absolute aesthetic code to which one must adhere), plus self-consciousness of one's formation within and through the totality of social relations. Contingency plus consciousness of totality, then, are the necessary conditions of both progressive art and social revolution. Having established Williams's basic position, let us now turn to his responses to Sartre's writings on human freedom in both his existentialist and Marxist periods.

In $T L R$, Williams had stressed the tension between a particular version of existentialist 'authenticity', interpreted as 'autonomy from social determination', and reified ideas of individual freedom: "Sartre emphasizes the danger of such social concepts as "function" or "duty", which can only be valid to the "unauthentic" man ... but the tendency to equate "social man" with "unauthentic man" is highly misleading. For what is being described as a social process is not the experience of a member, but of the subject or the servant' $(2011 \mathrm{~b}, \mathrm{p}$. 110). That Williams, a thinker of the totality, is keen to stress the possibility of forms of social inclusion (what will later be called alignment and formation) which are not 'unfree' or 'unauthentic', should not be surprising. In TLR this finds expression in the idea of the 'member', the self-consciously socially integrated person, in contrast to the relationships of oppression and determination implied by the positions 'subject' and 'servant'. For the member, who in Williams's view evades inauthenticity, is involved in a central process of decision-making; choice appears as the central category of freedom: 
The valuable element in the existentialist emphasis is the insistence on choice and commitment. It is true that unless an individual, in the process of his growth, achieves a real personal identity, he is incomplete and can be dismissed as 'unauthentic'. He must become deeply conscious of the validity of his ways of thinking and acting, so that he is not merely 'a creature' of the society, but also an individual, a man in his own right. (2011b, p. 111)

The process of self-conscious individuation which Williams is describing here is that which produces, as in the distinction outlined in Keywords, 'individuality' as opposed to a reified 'individualism'. While this is clearly a rejection of the idea of the mechanistic, fully determining abstraction of society, it is also a rejection of the fully self-determining individual in abstraction from the processes of alignment and formation inherent to the development of true individuality.

Williams finds another affinity with Sartre in the latter's insistence, in Being and Nothingness (1943), that 'existence precedes essence', i.e. that individuals do not possess a pre-existing hard core of attributes that determines their ideology or behaviour. In his 1968 review of The Philosophy of Jean-Paul Sartre (1968b), a collection of essays edited by Robert Denoon Cumming, Williams elaborates on this crucial notion and its contribution, but also its vulgarisation:

The major contribution of Sartre's early work, within a phenomenological tradition only recently much known in Britain, is his attack on the idea of a self, a character, which precedes action and consciousness and which can be used as a causal explanation of them. The implications of this successful attack are as crucial in literature, especially in the novel, as in any other field. But it is then an irony that the alternative idea, of the self as a project, should, both in his own work and, more grossly, in its popularisation, have confirmed social experience as a process of selfmaking. (The Guardian, 1968b, Nov 29, p. 11)

The paradox of Sartre's early work, for Williams, is the fact that Sartre's demythologization of the abstract, pre-existing individual has nevertheless provided fertile ground for extreme voluntarism in ideas of selfhood expressed both in 'romantic versions of existentialism' and in 'a kind of post-liberal individualism which is now our dominant ethos, in most kinds of social assent and dissent' (p. 11). But here we should recall that Sartre's individual, while not 'pre-existing' in the sense of having a determinate 'essence' which precedes experience and action, is nevertheless abstract in that its freedom is abstract; freedom as conceptualised by the early Sartre is indeterminate but absolute, inherent in the nature of man but possessed of no specific content. Since this is not so far from the negative liberty of the classical liberal 
tradition (also being indeterminate, absolute and inherent in the nature of man), it is not surprising that a version of Sartrean freedom should have been harnessed to new forms of abstract individualism in a period, towards the end of post-war social democracy, in which the market was indeed coming closer to becoming that incarnation of 'absolute order' which Williams had hypothesized in TLR. But Williams is also aware of Sartre's gradual theoretical turn towards Marxism (the political turn came earlier). In the 1968 review, Williams suggests that Sartre's interpretation of Marxism is an 'inversion of method', that is, of Marxist method; rather than proceeding 'downwards' from macro level structural determinants to individual behaviour and consciousness, as in the traditional Marxist model, Sartre moves 'upwards' from the individual to the deeper connection and practical links from which emerge larger social structures. This is 'a necessary antithesis' (p. 11), Williams concedes, but it falls short of synthesis, so that, beginning from 'the quite different starting point of lived relationships through which the abstractions of "individual" and "society" are both made and known' (p. 11), Williams must finally reject both orthodox Marxism and its Sartrean 'inversion'.

Now, Williams's rejection of Sartrean Marxism in 1968 is challenged, it seems, by the publication in English of Sartre's avowedly Marxist Critique of Dialectical Reason in 1976 (French: 1960). Williams was aware of the Critique in the French and appears to have read at least parts of it as of the 1968 review just discussed, in which he notes that 'the essential "Critique de la raison dialectique" (1960) is not available, as a whole, in English, and there has been less popularisation of the later positions than of the earlier, for reasons closely connected with what those positions are' (The Guardian, 1968b, Nov 29, p. 11) i.e. precisely because of the more explicitly Marxist argumentation. In a 1974 composite review of Sartre's Between Existentialism and Marxism (French: 1972) and two critical texts, Williams insists that 'someone has to say that the Sartre who emerged from the conflicts of the fifties is very much the more significant figure. This is certainly my own view' (The Guardian, 1974, May 25, p. 17); the fifties is broadly the period after Sartre's major existentialist productions but before the Critique, when Sartre was working out his relation to Marxism, most concertedly in Search for a Method (1957). In the 1974 review, Williams gives the following assessment of the late Sartre's Marxism, more comprehensible now with the English edition of the Critique: 
What Sartre is trying to do, as a Marxist, is to restore individual and collective response and responsibility to a system which had become, internally, abstract and falsely determinist. It is a mark of the backwardness of the state of the argument that the old response to perception of this difficulty - the adhesion of another system, abstract and falsely determinist, but dealing with individuals - should go on being attempted: trying to bind one shell to the other. But though Sartre takes the colour of this confused and difficult period, it remains true that in the "Critique of Dialectical Reason" (1960) Sartre himself took one of the very few original steps beyond it. (The Guardian, 1974, May 25, p. 17)

The 'other system', abstract but individualist, is psychoanalysis, while the binding of two deterministic shells gestures towards the various attempts, by the Frankfurt School and others, to install the subject into orthodox or vulgar Marxism by the psychoanalytic route. Such attempts, for Williams, produce not a conception of the totality, a true synthesis, but rather a dual determinism, a twice-alienating analysis within which human beings both making and situated in history remain as absent as in systems, like Althusserianism, which reject the subject entirely. The Critique, for Williams, moves tentatively beyond this.

In his 1977 review of the Critique, Williams argues that Sartre's late opus has been neglected or outright rejected both by English thinkers guilty of romanticising 'Sartre the post-war existentialist' (The Guardian, 1977b, Jan 20, p. 14) and by 'one important kind of orthodox Marxist: men who sustained their work by adherence to what they believed were the "scientific laws" of history and society, and among these laws "the dialectic" (p. 14). Williams argues, in agreement with Sartre, that 'the basic error of what has been known as "dialectical materialism" is its external character: its projection of predicated laws not only to Nature but on to Man and History' (p. 14). Indeed, Sartre's argument in the Critique is not merely against Engels's notion of the 'dialectic of Nature', but also the ascription of such exteriorising, abstract laws to the movement of human history and society. Sartre's most sustained encounter with Marxism asserts the need for something called 'dialectical materialism', but insists that it must be of a kind that fully incorporates both major clauses of Marx's claim (in The Eighteenth Brumaire) that 'Men make their own History ... but under circumstances ... given and transmitted from the past'. Thus the dialectic must be an account of praxis, the process whereby human beings, in a determinate situation, pursue aims and engage in actions, the synthetic outcome of which Sartre calls a 'totalisation' (Sartre, 2004, p. 830). As the observable movement of history, the dialectic must appear as both the product and as the motive force of the individuals through whose actions history both operates and is operated; 'in a sense', says Sartre, 'man submits to the dialectic as to an enemy power; in 
another sense, he creates it ... we must show how it is possible for it to be both a resultant, though not a passive average, and a totalising force, though not a transcendent fate' (pp. 3536). The dialectic is thus the 'unity of freedom and necessity' (p. 35) and this is a human, not a transcendent, operation:

The dialectical movement is not some powerful unitary force revealing itself behind History like the will of God. It is first and foremost a resultant; it is not the dialectic which forces historical men to live their history in terrible contradictions; it is men, as they are, dominated by scarcity and necessity, and confronting one another in circumstances which History or economics can inventory, but which only dialectical reason can explain ... on the level of ontology, the dialectic appears as the only type of relation which individuals, situated and constituted in a certain way, and on account of their very constitution, can establish amongst themselves. (2004, p. 37)

This is a clear advance on what Williams had described in 1968 as Sartre's Marxism, namely, an 'inversion of method', a working up from the ground of the individual to social structure. Here, Sartre is explicit in opposing the erasure of the world by the individual, or indeed viceversa: 'the universe becomes a dream if the dialectic controls man from outside, as his unconditioned law. But if we imagine that everyone simply follows his inclinations and that these molecular collisions produce large-scale effects, we will discover averages of statistical results, but not a historical development' (2004, p. 35). At the same time, Sartre is explicit in stating, in terms which come a little closer to the 'inversion' model, that the only way to avoid transcendentalism is, in fact, to appeal to a conception of the individual (as opposed to classes) as the agent of history: 'if we do not wish the dialectic to become a divine law again, a metaphysical fate, it must proceed from individuals and not from some kind of supraindividual ensemble' (p. 36). Now, Sartre privileges the individual here not because he believes in the individual as a non-historical, contingent atom, but because he wishes to refound dialectics as 'a reason rather than a blind law' (p. 37), which is to say as a procedure for acquiring knowledge rather than an impersonal process on the model of natural science. Since knowledge must be knowledge of something by something, Sartre argues, it requires a thinking subject, which can only be the organic individual. What makes dialectical reason distinct from 'analytical' reason (the impersonal, categorical reason Sartre associates with liberalism and the bourgeois social sciences), then, is that it names the epistemological operation wherein human individuals come to know a process which is both an object for them (the process of history) and of which they are the subjects (history being made by human beings). 
The epistemological process I have just described is what Sartre means when he uses the word 'interiority' in the quotation below, the italicised part of which (my emphasis) Williams reproduces in his review of the Critique:

The stance of the de-situated experimenter ... tends to perpetuate analytical Reason as the model of intelligibility; the scientist's passivity in relation to the system will tend to reveal to him a passivity of the system in relation to himself. The dialectic reveals itself only to an observer situated in interiority, that is to say, to an investigator who lives his investigation both as a possible contribution to the ideology of the entire epoch and as the particular praxis of an individual defined by his historical and personal career within the wider history which conditions it. (2004, p. 38)

Williams is in deep agreement with Sartre's analysis here, commenting that this 'kind of inquiry, taking the weight of every clause, is now so rare, whatever name may be given to it, that even its definition is a landmark' (The Guardian, 1977b, Jan 20, p. 14). The idea of interiority is vital to Williams not because it recuperates the individual for Marxism, which would violate the principle of totality, but because it foregrounds the dimension of experience in the production of history. Sartre's analysis makes experience into a form of reason, an epistemological procedure, rather than one by which an isolated observer passively absorbs and is acted upon by information coming from 'somewhere else'. Lukacs and Goldmann's epistemological strategies (as they have appeared in Williams's engagements, at least), imputed class consciousness and homology respectively, seem to fall markedly on the side of analytical reason in comparison to the late Sartre's formulation, which is to say that they fall on the side of the observer in exteriority. The Lukacsian observer, in effect the professional revolutionary, observes the proletariat from a distance, imputing to it what he/she regards as an appropriate consciousness. Goldmann's critical-intellectual observer, establishing the coherence of literary text and historical development, is more detached, more 'exterior' still. The achievement of what Williams regards as the necessary experiential involvement of authentic revolutionary activity will, from either of these positions, on the evidence of Sartre's analysis, be problematic.

In Sartre's Critique, dialectical reason is not the 'reason of nature', which is the domain of the natural sciences and is carried out by scientists from a position of exteriority, but the 'Reason of History' (2004, p. 36), the becoming-known-to-itself of a process which has its origin and essential substance in human beings. Williams's humanist model of cultural extension, experience and response which, in its relation to the individual, is analogous to the 
late Sartrean conception, bears striking epistemological resemblances to the procedure of dialectical reason as Sartre elaborates it in the Critique. Indeed, contra Eagleton's claim that Williams's advocacy of an extending participatory democracy is non-revolutionary by virtue of its being idealist, that is, of placing a fallacious faith in the power of human reason, we must answer that the kind of reason to which Williams gestures is really a dialectical reason of the Sartrean type, and ought to be defended against attacks such as Eagleton's which are better levelled at non-Marxist articulations of analytic reason. Eagleton believes Williams to be propagating an idealism in which the observer, somehow standing apart from the material determinants of her own consciousness, effects both those determinants and future social change merely by learning/responding in new ways i.e. by thinking differently. In fact, Williams's model, like Sartre's, is one which aspires towards an epistemology in which thought apprehends its own material conditions, and in doing so produces a new material condition in which history has been made intelligible by dialectical reason. This is the sense in which Sartre says that 'Marxism is History becoming conscious of itself' (2004, p. 40): dialectical reason as the process whereby the subject becomes conscious of itself as both subject and object. Analytic reason, by contrast, holds the object at bay, outside of the subject, and attempts to discover its laws, including the production of what can then only appear as the 'fiction' of a subject (Althusser). Eagleton views Williams as projecting a 'circular totality' onto history, rendering causal analysis of how material processes impact consciousness impossible. What Williams is in fact doing, with Sartre, is denying that a subject constituted by material processes is in fact a pure object or resultant. He instead posits the double-life of a subject which is irreducibly both subject of and to history.

Marxism and Literature appears in 1977, a year after Sartre's Critique appears in English and the same year in which Williams publishes his review. It seems to me that the Critique was a significant influence on that text, and its basic logic definitively informs the cluster of related politico-aesthetic essays which Williams writes in the late seventies and early eighties, of which the 'Alignment and Commitment' chapter of $M \& L$ is effectively a part. I turn now to those texts, and to a comparative analysis of Williams and Sartre on the question of artistic freedom and political commitment. We shall find that while Williams finds something of value in the aesthetic positions of the early Sartre, he arrives at a view of artistic freedom which is heavily indebted to the philosophical arguments of the Critique, with its dialectical synthesis of freedom and necessity. 


\section{Williams and Sartre on Freedom and Commitment in Literature}

In both 'Commitment' (1978) and 'The Writer: Commitment and Alignment' (1980 hereafter 'The Writer'), Williams casts Sartre as a key source of debates about politics and art around the term 'commitment'. Sartre's is 'the original argument for "commitment"' (1990b, p. 256) and 'commitment became the normal term, in our own time, because of the famous intervention by Jean-Paul Sartre at the end of the war when he wrote...' (1989n, p. 77); the intervention to which Williams then refers is the following, from Sartre's 'The Purposes of Writing' (1960):

If literature is not everything it is worth nothing. This is what I mean by 'commitment'. It wilts if it is reduced to innocence or to songs. If a written sentence does not reverberate at every level of man and society then it makes no sense. What is the literature of an epoch, but the epoch appropriated by its literature? (Sartre, 2008, pp. 13-14)

Williams states that Sartre wrote this 'at the end of the war'; this is incorrect (the quote is from 1960). Whether this was parapraxis on Williams's part or an acknowledgment that the idea of commitment being referred to is that established in What is Literature? (1948), is unclear. It should also be pointed out that this passage, which hails from the period of the Critique, contains elements of both periods. The noble universality of the first few sentences evokes Sartre's presentation of prose writing as the apotheosis of freedom in What is Literature?; the final sentence prefigures the procedure of apprehending one's own material conditions or 'objectness' in the Critique. Distinguishing between the early and late positions will help us to establish the relation between the idea of commitment in the early Sartre, to which Williams refers and which grounds his discussions, and ideas found in the Critique which are crucial to understanding the position which Williams in fact comes to.

The question to which Sartre's comment, above, refers us is whether literature must or should have, a broad social application, 'commitment' to something which ranges far beyond the individual writer. Williams points out, both in $M L$ and in 'Commitment', that such a position is open to Adorno's critique that commitment as such is 'politically polyvalent': 'Adorno's critique of this position is convincing ... [Sartre's view] leaves all questions of commitment in writing unanswered. (It is of course an aspect of Sartre's commitment to freedom that they are left unanswered)' (2009 [1977], p. 202). Now, commitment in the very broad sense sketched in 'The Purposes of Writing' is indeed politically polyvalent (Sartre's larger 
argument, as we shall see, is not), and Williams's account, in 'The Writer', of the backlash against politically committed prose is grounded in this slipperiness of the political signifier. There Williams identifies three forms of resistance to the notion of commitment. First, the backlash against the cause to which left writing was supposed to be committed (authoritarian Communism), from which 'it was no distance at all to saying that writers should keep out of that kind of political and especially left-political thing' (Williams, 1989n: 78). Secondly, the accusation, given historical support by Stalinist literary repression, that commitment was in fact 'the practice of an authority above the writer which was telling him what to write and how to write' (1989n, p. 78). Here Williams turns to Brecht, writing against Lukacs:

They ${ }^{69}$ are, to put it bluntly, enemies of production. Production makes them uncomfortable. You never know where you are with production; production is unforeseeable. You never know what is going to come out. And they themselves don't want to produce. They want to play the apparatchik and exercise control over other people. Every one of their criticisms contains a threat (Brecht quoted in Benjamin, 1973, p. 3)

Williams is entirely in support of this endorsement of artistic freedom from Brecht, and sees it as the expression of a healthy, socialist distinction between 'a commitment to production linked to a cause, and on the other hand subservience to some version of desirable production arbitrarily decided by a party and its ideologists' (1989n, p. 79). This socialist counterinterpretation of commitment, Williams notes, was not enough to prevent a general fatigue: 'it was very difficult to sustain it in the period of the cold war and that mood of confession of errors ... the two very different ideas - of commitment and subservience - were pushed together and seemed to support each other' (p. 79). The third backlash against commitment that Williams identifies was the critique of 'the false commitment of the inserted political reference' (p. 80), what we might think of in Sartrean terms as commitment in bad faith, as opportunism or pure propaganda, that 'superficial kind of writing which took care to include the political references that went with the cry of the moment' (p. 79). Williams concurs with this opposition to the uncritical attachment to certain habitual kinds of content, and refers more or less approvingly to Marx and Engels's opposition to 'tendency' literature within the socialist movement (Lukacs, in the name of a robust realism, had opposed the same phenomenon).

${ }^{69}$ Brecht means advocates of, in one form or another, socialist realism. 
Now, against these negative characterizations of commitment, Williams reminds us that 'commitment still meant, at its best, taking social reality, historical reality, the development of social and historical reality, as the centres of attention, and then finding some of the hundreds of ways in which all those processes can be written' $(1989$, p. 79). Commitment, then, as the commitment to something like a realism (echoing Lukacs), but one which, devoid of any specific political content, does not obviously escape Adorno's political polyvalence; all political positions, after all, stem from, legitimate and pursue their aims via a set of historical and ontological assumptions. Here we may return to Sartre, for Williams's characterisation of the arguments of What is Literature? as essentially formal or 'conceptual' (2009 [1977], p. 202), that is, on the side of freedom but abstracted from concrete political goals, is not entirely accurate. This is important to clarify since Williams appears to agree with Sartre only when his argument can be interpreted in this way.

Sartre's argument in What is Literature? accords with his basic existentialist position in the forties. Man is free, a pure contingency. He can either be aware of this (authentic) or unaware or in denial of it (unauthentic). It is in this sense that 'existence precedes essence' i.e. that what person does determines what he/she is (their 'existence'), as opposed to that being determined in advance by an 'essence' which pre-dates the subject in its real interactions with other people and with objective reality. Man aims at being objective, at having 'being' independently of his actions and intentions (man as en-soi or 'in-itself'), but man is 'condemned to be free', having full responsibility for what he is (man as pour-soi or 'foritself'). Literature, in this context, is both process and product of an interaction between two freely acting and producing agents, author and reader, who collaboratively produce the literary object as an expression of the freedom of both, recognising in so doing the freedom of all men. For Sartre, literature takes the form of an appeal from author to reader, 'the writer appeals to the reader's freedom to collaborate in the production of his work' (2001, p. 34) and this, being an appeal primarily to the reader's unconditioned freedom, it is also an end in itself or 'unconditioned end'. At this early stage in the argument, it could well be claimed that literature as an appeal from the unconditioned freedom of the author to the unconditioned freedom of the reader, is indeed politically polyvalent; one may after all 'freely' chose to write in defence of fascism. But here Sartre's argument takes an overtly political turn; he moves from literature as the implicit contract between two unidentified free agents (author and reader in abstraction) and considers the conditions within which a truly free writing can 
occur at all, emphasising the reality of the situated writer making a specific and concrete appeal to a real audience:

The freedom of writing implies the freedom of the citizen. One does not write for slaves. The art of prose is bound up with the only regime in which prose has meaning, democracy. When one is threatened, the other is too. And it is not enough to defend them with the pen. A day comes when the pen is forced to stop, and the writer must then take up arms. Thus, however you might have come to it, whatever the opinion you might have professed, literature throws you into battle. Writing is a certain way of wanting freedom; once you have begun, you are committed, willy-nilly. (2001, p. 49)

Taking the notion that man is 'really' free, an unconditioned end, at face value, the very possibility of an unfree (undemocratic) society, in which one must take up arms to defend freedom, may seem paradoxical. There are real contradictions here which it is not the purpose of What is Literature? to resolve. Suffice it to say that Sartre in his existentialist phase is at least as concerned with the capacity of man to perceive his freedom (to be authentic), as with the question of his literal or political freedom. In the sphere of literature, this implies the distinction between an alienated and a non-alienated literature, a literature which appeals to man's essential freedom and a literature that does not. Thus, Sartre argues, 'if it is true that the essence of the literary work is freedom totally disclosing and willing itself as an appeal to the freedom of other men, it is also true that the different forms of oppression, by hiding from men the fact that they were free, have screened all or part of this essence from authors' ( $p$. 116). This false consciousness on the part of authors is compounded by the fact that while literature, by its nature, is an appeal to the freedom of all men (freedom of the totality) specific, historically situated authors necessarily are only read by a small fraction of humanity. Sartre erects upon this fact a crucial distinction between 'abstract universality', wherein a writer 'postulates the constant repetition in an indefinite future of the handful of readers which he has at present' (p. 118), in effect taking a limited, bourgeois audience for all of humanity, and 'concrete universality', or 'the sum total of men living in given society' ( $p$. 119). At various points, Sartre refers to this distinction as that between one's 'virtual public' and one's 'real public'. It is to concrete universality, to one's 'real public', that the writer's work must be addressed and to the freedom of which it must appeal, if it is to be 'a concrete and liberated literature' (p. 119).

The lack of immediate existence (availability as an audience) of a 'real public' for whom one may write is an obstacle and a contradiction which Sartre resolves in favour of a concretely 
Marxist politics, so that 'actual literature can only realise its full essence in a classless society' (2001, p. 120). Class, argues Sartre, is the fundamental social co-ordinate of the split between abstract universality and concrete universality, the virtual and the real public. Class is the gulf between literature as an appeal to the freedom of all men, and literature as bourgeois ideology, partial and oppressive:

Only in [a classless] society could the writer be aware that there is no difference of any kind between his subject and his public. For the subject of literature has always been man in the world. However, as long as the virtual public remained like a dark sea round the sunny little beach of the real public, the writer risked confusing the interests and cares of man with those of a small and favoured group. But, if the public were identified with the concrete universal, the writer would really have to write about the human totality. (2001, p. 120)

It is the advent of a classless society, then, which allows literature to realise its essence as the expression of and appeal to the freedom of all men, so that the writer can finally write for all men, as his real public, and about all men, as the social totality. The important thing to note here is that a 'concrete' (i.e. historical) literature does not only require the freedom of the author, but also of the reader: 'It is not enough to accord the writer freedom to say everything; he must write for a public which has the freedom of changing everything' (p. 122). Formal discursive freedom is here insufficient. Freedom, argues Sartre, is only meaningful in the classless society of the socialist democracy, entailing 'suppression of classes, abolition of all dictatorship, constant renewal of frameworks, and the continuous overthrowing of order once it tends to congeal' (p. 122). Liberal or negative freedoms from the kinds of coerced commitments which Williams discusses in 'The Writer' are necessary but not sufficient; the freedom to which a concrete literature appeals must also be a positive project, so that 'concrete literature will be a synthesis of Negativity, as a power of uprooting from the given, and Project, as an outline of a future order' (p. 122).

For Sartre, then, literature must demonstrate the power/freedom of man to change himself and his situation, to constantly overturn all embedded and sclerotic hierarchies, but it must also posit a constructive social project. ${ }^{70}$ And this is not an abstract proposal; it entails a

\footnotetext{
${ }^{70}$ Sartre, of course, did not do this in his plays. From Williams's analysis of Brecht, moreover, we may conclude that the German playwright, while injecting a welcome contingency and humanism into expressionism (bringing it almost to the point of dissolution), also did not posit a constructive project. As we shall see in Chapter Three, Gramsci's concept of hegemony provides Williams with the theoretical ground for a concrete cultural positivity.
} 
definite commitment to a particular politics and a particular project which, while framed as the product of the freedom of the author and reader is far from politically polyvalent:

We must historicize the reader's goodwill, that is, by the formal agency of our work, we must, if possible, provoke his intention of treating men, in every case, as an absolute end and, by the subject of our writing, direct his intention upon his neighbours, that is, upon the oppressed of the world ... [but also] show him ... that it is quite impossible to treat concrete men as ends in contemporary society ... In other words, we must transform his formal goodwill into a concrete and material will to change this world by specific means in order to help the coming of the concrete society of ends. For goodwill is not possible in this age, or rather, it is and can only be the intention of making goodwill possible ... In short, we must militate, in our writings, in favour of the freedom of the person and the socialist revolution. It has often been claimed that they are not reconcilable. It is our job to show tirelessly that they imply each other. (2001, pp. 211-213)

There is a lot to unpack here. Firstly, the prevalence of the word 'must' indicates that Sartre is not making a set of recommendations, but is setting out a moral programme, a normative theory of committed literary practice. Secondly, Sartre is very clear that writers must not simply 'be' socialists, or advocate socialism as public figures; 'we must militate, in our writings' (my emphasis) says Sartre, insisting that the content of one's writing must itself be 'for' both 'the freedom of the person' (liberal rights) and 'the socialist revolution'. Thirdly, we are given some indication, not of specific content, but of what the content of a committed writing must 'show' about the world, namely that it is 'impossible to treat concrete men as ends in contemporary society' and that the freedom of the person and the socialist revolution are not antitheses but rather mutually constitutive aspects of the same emancipatory formation. This passage, at least, calls into serious question Williams's claim that Sartrean commitment is 'politically polyvalent'; it seems clear that Sartre is advocating not commitment in abstraction, but concrete commitment to the cause of freedom and of socialist revolution, to be militated for in writing, and which is implied in the nature of literature as the collaborative creative activity of free individuals.

The question we must now ask is: why does Williams choose to interpret Sartre as though he is in favour of the polyvalence of political content? The simplest explanation is that Williams did not regard the latter parts of What is Literature? as carrying the core message of that text. It is only late in the text, after all, that Sartre makes the explicit recommendations of political content given above; the bulk of the argument does indeed treat the issue of artistic freedom in a relatively conceptual/abstract manner. The more salient explanation, however, is that 
Williams is trying to recuperate the idea of commitment away from its older, problematic connections to particular kinds of 'imputed' political content and towards something implied in the totalising analysis of the Critique: commitment not to a specific politics but to the comprehension of one's material conditions, an understanding only achievable on the basis of the thorough routing of ideas founded on the reifying binary of the individual and society. Consider Williams's comments on Sartre in the 1984 review of de Beauvoir's Adieux, where he simultaneously applauds Sartre's attempt to 'recover communism for liberty - still the central project of our time ... an attempt wholly distinct from the simple contrast between communism and liberty which ... ends with an accommodation to capitalism' (New Society, 1984b, June 21, p. 470) and criticizes 'the persistent bourgeois position that one's freedom is constrained by the freedoms of others' (pp. 470-471), as well as Sartre's 'voluntarism' (p. 471). In other words, Williams is entirely in favour of pursuing a materialist theory and practice of freedom (libertarian communism); what he will not abide is any conception of freedom which abstracts the individual from others and from the social structure (historically, the bourgeois liberal view).

Let us be clear in noting that, for Williams, 'commitment' in literature does not/should not mean exclusively commitment to socialism. But neither does Williams believe that this reductive meaning of commitment has been the dominant one in the period inaugurated by Sartre's popularization of the term: 'What we have come to understand, I think, is that commitment was not, for the most part, a positive proposition. It was mainly a response to ... the position that the artist, by definition, must be a free individual; that to be an artist is to be a free individual' (1989n, p. 81). Commitment, here, appears as a negative political reaction to the liberal-Romantic conception of the artist as an entirely free creative agent. While the latter is not really so far from Sartre's position in the bulk of What is Literature?, Williams acknowledges that 'there is a version of commitment which can include that, because if you are a free individual you can choose to commit yourself' (p. 81). But then the 'libertarian' conception of freedom, while an improvement on the false and coerced commitments, is also insufficient. The problem is precisely the element of 'voluntarism' which Williams ascribes to Sartre's work generally. Voluntaristic ideas, in Williams's schema, are invariably symptomatic of reification, the artificial isolation of the individual from society. Thus commitment in the sense which Williams attributes to Sartre (freely chosen commitment), is tendentially liberal and limiting in conception. As Williams describes it in 1978: 
'Commitment' implies conscious choice, and thus voluntary choice. This makes it sound almost liberal, and it is indeed, in one sense, a profoundly liberal idea. It presupposes writers who, as it were, survey the spectrum and decide to which part of it they will move. It also presupposes a natural state of innocence, free of ideology, from which a writer may or may not choose to move, committing himself, if he moves that way, to a set of acquired positions and values. Historically this is the bourgeois concept of the individual, who exists, as it were, free and formed, before he decides to enter into relationships, associations or contracts, or, in the extreme case, to refrain from doing so or to enter into as few as he can. (1990b, pp. 257-258)

In contrast to this atomizing view, Williams, in 'Art: Freedom as Duty', emphasises that 'We are born into the specific relationships of a family, of a society, of a historical phase, well before any questions of conscious choice and any realisation of the possibility of freedom can arise' (1989b, p. 91). Here Williams is writing in strict opposition to the early Sartrean notion of a freedom of the individual which pre-exists one's situation in society. Williams was sympathetic to Sartre's 'existence precedes essence' schema on the basis of its antiessentialism and the possibility of it being linked to a historical and totalising theory of individualization through material practice in relation to others. It had to be rejected, however, insofar as it practiced a kind of libertarian extremism, an apparently limitless endorsement and theorisation of contingency. For Williams, freedom is unthinkable 'except in terms of its specific social production' (p. 91); social influence, moreover, is not something which must escape the critically-minded artist's consciousness: 'in an important sense, a writer is not free, and knows in the course of his practice that he is not free' (p. 92). In place of the early Sartre's libertarianism of human freedom, Williams enjoins us to think 'in terms of formation and alignment ... every artist who reflects on his experience and development becomes deeply aware of the extent to which these factors of formation and alignment in his own very specific history have been decisive to a sense of what he is and what he is then free to do' (p. 91).

One of the most important pressures upon the freedom of the situated writer is of course the language-system into which he is born and embedded. Language, 'the medium from which he must try to make his particular art' (Williams, 1989b, p. 92), is both a factor in the freedom of the writer and in his being restrained, his 'indispensable resource', a 'constant stimulus', and at the same time 'a set of limits, of constraints ... directions this way and that' (p. 92). Between mental conceptions (themselves strongly influenced by elements of personal formation and socio-cultural alignment) and the material-productive practice of writing lies a highly pressurised field of influence stemming from the material and historical structure of 
the language itself: 'between the conception as it moves in the mind ... and [its] quite material realization in the words, there is a very complex process which most writers spend their lives trying to understand, and perhaps never fully understand. It is a material process' (p. 92). Williams is keen to emphasise this surprising, unplanned aspect of the confrontation of the writer with language, the fact that 'many writers have correctly observed a moment of surprise when the creation seems to be going in a way which they had not fully intended' ( $p$. 93). The outcome of this merely contingent contact with language, while it can, 'in some instances, be diagnosed as failure', it is just as often the case that 'what happens at that stage comes to be seen as more important, as having more substance to it' (p. 93).

Williams's analysis of the confrontation of artistic creation with the materiality of language returns us to the question of choice, but a choice which now appears not as the expression of an abstract but of an emergent contingency, a literary fecundity which, while 'appearing' only to the individual, has in fact been co-parented by the material and social forces of formation, alignment and language. This process, moreover, which in 1978 Williams describes as culminating in 'moments' or 'points' of significant artistic praxis, in no way negates the freely choosing individual in the positive sense implied by 'individuality': 'Now of course we all become, or hope to become, fully-formed individuals, and we do have real choices - to allow ourselves to be pushed this way or that or to resist that kind of push. Nothing I'm saying diminishes the importance of that kind of mature choice ... I wish it was more widely exercised' (1989b, p. 91). The individual writer does and should make choices, then, but the crucial thing for Williams is that these choices take place within a process which in important ways surpass the writer, and which are indelibly marked by formative and aligning forces which the writer did not choose. 'And what, then, is freedom?', Williams wonders, 'Or what is duty?' (p. 93). Freedom, firstly, must indeed include the liberal freedom from 'arbitrary interferences' (p. 95) which Sartre had also recognised as necessary. But beyond that, freedom comes to be attached to an emergent project which arises from consciousness of formation and alignment, that is, of the material, social and linguistic conditions which ground one's exercise of resistance or passivity in the face of established conventions. As I have already noted, Williams's position is that the only 'duty' which a writer can have is to follow through on the hesitation to conform, the potential for originality announced by 'the hesitation at that point, when the words can come all too easily ... to hold yourself at that point with some hope of moving beyond it' (p. 95). But that act of hesitation and emergence is predicated upon recognition of the determining pressures against which 
original practice arrays itself. Freedom, Williams argues in 'The Writer', is not freedom from formation and alignment, as it so often appears in the early Sartre, but the freedom to act in conscious defiance of formative pressures:

It is one of the most surprising things about [critics of commitment] that they say, 'I only write as a free individual, I only write what I want to write', but in fact what they write is, in majority, already written and what everybody else knows. That of course is an illusion of freedom. This is when you are free to choose, or to choose to try to alter, that which is really pressuring you, in your whole social formation, in your understanding of the possibilities of writing. (1989n, p. 87)

Or, as he puts it in 'Art: Freedom as Duty':

We have to think that the most significant freedoms may therefore be discovered in the consciousness of our true conditions, including conditions which necessarily set certain limits on us. Not the arbitrary limits, which we must always refuse, but that placing in a people, in a language, and in a time, which is not a denial of freedom but, properly used, the means of its realization. (1989b, p. 95)

So, our 'understanding of the possibilities of writing' is linked to 'consciousness of our true conditions'; what considerable freedom there is in artistic practice is symbiotically linked to a materialist practice of combined self-reflection and social critique. We are now in a position to address the striking similarity between Williams's development of a holistic, totalising aesthetic epistemology out of the discredited binary of 'pure' artistic freedom and commitment, and the epistemological divide between the early and the late Sartre (and with this the influence of the Critique on Williams's late aesthetic essays).

For Sartre in What is Literature?, the enemy of consciousness was inauthenticity, the inability to perceive or acknowledge absolute freedom. Authenticity, by contrast, was the perception or acceptance of freedom, of man as an 'unconditioned end'. This, in Williams's analysis, is close to the ideology of the 'pure artist' of individualist contingency, writing 'from the heart' and 'unconditioned' by social forces. 'Commitment' or 'duty', within this reifying and tendentially liberal framework, can only appear as arbitrary restraint (although, as we have seen, the early Sartre was not above making concrete demands of the committed writer). In the Critique, by contrast, the idea of man as an 'unconditioned end' has been replaced by the Marxist notion of freedom within pre-existing parameters, history as made by man but in conditions transmitted from the past. Indeed, the Critique defines praxis as 'the activity of an individual or group in organizing conditions in the light of some end' (Sartre, 
2004, p. 829). Revolutionary praxis, of course, takes as its end socialist revolution; replace 'organising conditions' with 'formation and alignment' and we are not far from Williams's analysis, in which the committed writer has as his 'end' the transmission of new aesthetic experience via the commitment to emergence. In the Critique, the enemy of consciousness is no longer inauthenticity but analytic reason, precisely the reified and exteriorizing logic that would oppose coerced or false commitment to the isolated 'pure artist'. Dialectical reason, by contrast, the core epistemological procedure of the Critique, is precisely 'the intelligibility of praxis at all levels' (p. 828) i.e. self-consciousness of thought and action wherein the individual becomes aware of itself as materially conditioned and conditioning. This is precisely the logic of Williams's politico-aesthetic essays; the artist is enjoined, via a process of intellection which is remarkably similar to Sartrean dialectical reason, to a) become aware of the constitution of both his subjectivity and his art in the material processes of formation and alignment and b) direct, through self-conscious aesthetic praxis, 'emergent contingency' in the direction of new artistic creation.

What of revolution, given this line of aesthetic argument? Eagleton (1976) had criticised Williams for his 'idealist' belief in the power of deliberative reason, but it is better to say that Williams 'believes in' the power of interiority (self-conscious praxis). Art, in Williams's view, is not only a process of expression but also of discovery; emergent art is only possible under conditions of self-understanding, which entails, since the isolated individual is a myth, an understanding of social relations. Thus, as Williams argues in Marxism and Literature, 'In any specific society, in a specific phase, writers can discover in their writing the realities of their social relations, and in this sense their alignment. If they determine to change these, the reality of the whole social process is at once in question' (2009 [1977], p. 204). The artist, then, can be a revolutionary if he goes through with that hesitation to conform to, or merely reflect, his material conditioning; this is not the 'metaphysical rebellion' which Williams had criticised in the early Sartre, but the discovery of real social conditions, which are always extra-individual, and the commitment to changing them. This, for Williams, can only be realised in an educated, participatory democracy (the end-point of Williams's 'long revolution') in which, we may now argue, dialectical reason is the normative epistemological horizon and the production of freedom entails the perception of material and social formations: 
This is why the claim for the freedom of the artist is necessarily a claim for quite new kinds of freedom, an acknowledgment of the need for freedom for everyone in society. This sense connects with the deepest notions of an educated and selfmanaging democracy as the best cultural and political model, distinct from the received models with which other ideas of art have been so commonly associated. (Williams, 1989b, p. 95)

Let us now, in establishing precisely what is meant by 'everyone in society', pass to a more practical set of considerations. Since revolutions are not carried out by man in the abstract, it follows that the material and social formations which dialectical reasons enjoins us to 'interiorize' will not be uniform over the surface of the globe. The freedom of everyone in society may be acknowledged as a need, but it may also have to be acknowledged as a series of different needs, or of different freedoms. In the passage from abstraction to concreteness, we face the reality of groups differently constituted as cultures, nations and peoples or, in other words, as distinct particularities. In the early seventies, partly, I argue, due to his exposure to Sartre's work on the Basque separatist movement, Williams became increasingly concerned with questions of particularism, cultural plurality and self-determination. The interaction of these considerations with the foregoing philosophical questions, that is, of the epistemological project of totality or dialectical reason with the concrete realities of placed and classed struggles, will be the subject of the remaining sections in this chapter.

\section{From the 'common culture' to the Burgos Trials}

In his introduction to the edited collection Who Speaks for Wales? Nation, Culture, Identity: Raymond Williams (2003), Daniel Williams is surely right to foreground the dissonant combination, in Williams's work, of experience in a place and the abstract, objective insights gleaned from a prestigious formal education:

Williams's writings on Wales are consistently informed by that backward gaze from a formal education to the 'intense association' of family and childhood in the Welsh Border village of Pandy. In both his theoretical writings and his fiction Williams shares Hardy's 'special gift' of relating his own early history to the 'insights of a consciously learned history and of the educated understanding of nature and behaviour', of seeing 'the native place and experience but also the education.' (D. Williams, 2003, xv)

This dichotomy, I would argue, is central to Williams's work in general, but it achieves its highest pitch in Williams's writings on Wales, where he speaks dialogically from what D. 
Williams describes as the 'ambivalent location that lies at the heart of his fictional and theoretical engagement with Wales and Welshness' (xxiv). The ambivalence of this position can be related to the concept, liberally applied by Williams scholars, of the border, the liminal space within and across which the subject is forced to apply both experience and reason, lived and abstract knowledge, to make sense of his surroundings and identity. This also implies a kind of combined presence and absence: the presence of the native, with his lived experience, and the partial or total absence of a) the subject who relies only or mainly on abstract or objective knowledge (lacking the lived experience) and, as I argue here, b) a certain quantum of knowledge which may be read as being inaccessible to experience, at least in the sense implied by 'lived'. Objective knowledge, in particular that related to structural class relations, haunts Williams's work in a way that I believe Williams himself found difficult to interrogate; nevertheless, such knowledge becomes increasingly important for Williams in the seventies and eighties with his analyses of nationalism and the politics of place. Sartre's writing on Basque nationalism influenced Williams's 'nationalist turn' in the early seventies; in this section I will draw on this work, alongside the conceptions of knowledge outlined in the previous section, to examine the relation between class and nation in the socialist politics of both thinkers.

The title of D. Williams's introductory essay is 'The Return of the Native', a reference to Hardy's novel which neatly encapsulates the temporal trajectory of Williams's writing on Wales and the politics of place: an increasing engagement with a place of origin and the implications of that emphasis, properly beginning with 'Culture is Ordinary' (1958) and Border Country (1960) but increasing significantly in volume and depth in the early seventies with the publication of 'Who Speaks for Wales?' (1971), a review of Ned Thomas's The Welsh Extremist (1971). What the return permits, under propitious circumstances, is the enrichment of experiential knowledge with information gleaned from external sources of knowledge, the 'outside' component of what Williams describes as 'seeing the matter in my own living conditions from both inside and outside' (2003b, p. 28). Here I would like to layer on top of this directionality a rough tri-partite structure, corresponding with a) the period of the late fifties and sixties, b) the early to mid-seventies and c) the late seventies through the eighties. In the first period, Williams advocates cultural equality and anti-elitism (opposition to anything resembling an 'imputed' culture), focussing on the importance of self-made meanings derived from experience and the idea of universal solidarity rooted in an amorphous 'equality of being' (2013 [1958], p. 337); this is best encapsulated in the 
conclusion to Culture and Society, in which Williams calls for 'diversity without separation' (2013 [1958], p. 334). In the second period, under the influence of Welsh nationalist currents and a broader and deeper understanding of his own Welsh cultural inheritance, the 'without separation' element weakens, though under the same presumption that the goal of a cultural politics is a self-defining, 'free' people or community, which may or may not take the form of the traditional nation-state. Towards the end of the seventies and throughout the eighties, Williams increasingly advocates an approach incorporating both experience and 'the politics of abstract analysis' (2009 [1977], p. 182) i.e. the application of objective knowledge. Engaging with left critiques of nationalism and encountering conceptual difficulties within the politics of Welsh nationalism, this third period is characterised by a holistic view of the role of class and nation in a socialist politics, in keeping with his long-standing commitment to totality. Williams's position increasingly mirrors the Sartre of the early seventies, both in terms of a general epistemology (dialectical reason) and the role of minority nationalism as a necessary component of the socialist project.

It is the conspicuous absence of geographically delineated place in Williams's theoretical works of the fifties and sixties ${ }^{71}$ that is probably responsible for what D. Williams (2003) rightly criticises as a serious aporia in the critical treatment of Williams's later engagement with these issues. Nevertheless, in the notion of a common culture and its enemies, we can establish the links between the early and late work, and detect the nascent impulses behind the mature shifts. In 1958, Williams publishes the essay 'Culture is Ordinary' and includes a meditation on the idea of a common culture in the Conclusion to Culture and Society ('The Development of a Common Culture'). These texts, along with the 1968 essay 'The Idea of a Common Culture' which summarises and builds upon them, confirm the narrative that sees the early Williams as rejecting the traditional nationalist emphasis on political and cultural separation, but belie the assumption that this implies cultural or experiential homogeneity; precursors to what D. Williams describes as Williams's mature advocacy of 'a culturally diverse society based on the acceptance of a necessary ambiguity in cultural and political identity' (2003, xlv) are present, in muted forms, from at least these early works.

In $C S$, Williams begins from the position that society must not be viewed as a 'ladder', with its definition the purview of an elite and a population defined as a 'mass' or 'the masses'

\footnotetext{
${ }^{71}$ It is firmly present, of course, in the novels Border Country (1961) and Second Generation (1964).
} 
locked out of the processes of definition by artificial scarcities of elite education and political power. 'For in the end, on any reckoning', argues Williams, 'the ladder will never do; it is the product of a divided society, and will fall with it' (2013 [1958], p. 332). The ladder model, which expresses 'the inherent dominative mode’ (p. 336) of class societies, must be opposed by 'democracy' and 'solidarity', which 'is potentially the real basis of a society' (p. 332). The problem of building a 'fully democratic society' (p. 332), argues Williams, 'can be defined as one in which diversity has to be substantiated within an effective community which disposes of majority power' (p. 332). What is being imagined here is a single community run on democratic principles, but free from the yoke of elite power and minority definition. At this point, the rationale for adopting the aim of 'achieving diversity without creating separation' is attributable to a kind of Millian rationalism; ${ }^{72}$ the point is to acknowledge the limits of dogma and intellectual over-confidence in uncertain times and, whatever one's own starting point, 'to listen to others who started from a very different position' (p. 334). Thus, argues Williams 'It is necessary to make room for, not only variation, but even dissidence, within the common loyalty' (p. 334). That there should be a 'common loyalty', a sacrosanct solidarity, is not questioned at this stage and the idea of a common culture is expressed as the democratic circumvention of the elite and artificial hijacking of common cultural processes. The acknowledgement of difference and variation is primarily a means to the end of 'common government' (p. 337).

The title phrase of 'Culture is Ordinary' (1989d) carries the same emphasis as Williams's analysis in $C S$, that culture is, in effect, classless, or ought to be, and that it is the province of everyone who lives in a given society, not only a 'cultured' elite. Everyone 'has' culture because culture is not merely 'high culture' but, famously, a 'whole way of life'. Common, in this sense, means something akin to 'public', a common stake held in something in which there is universal involvement and shared responsibility. A Welsh dimension to the discussion emerges in the initial descriptions, but primarily as a 'proof' that culture is everywhere, and that every community produces its own culture via experience, conservation and emergence (culture as tending and growing). The political thrust of the Welsh descriptions is an emphasis on working-class culture in general, which could be a model for England, itself being artificially defined by a minoritarian cultural hegemony, as much as Wales: 'I think this way of life, with is emphases of neighbourhood, mutual obligation, and

\footnotetext{
${ }^{72}$ Indeed, Mill had been a key figure in Culture and Society.
} 
common betterment, as expressed in the great working-class political and industrial institutions, is in fact the best basis for any future English society' (1989d, p. 8). The prerequisites of what Williams describes as 'a good common culture' (10) are that it is a) grounded in solidarity, b) produced and agreed upon in common, by deliberation, c) opposed to the Leavisite disavowal of the cultural legacy of the industrial revolution and popular education and d) opposed to the distinction between 'high' and 'low' culture.

With 'The Idea of a Common Culture' in 1968, Williams reaffirms the goals of his previous writings while emphasizing in a stronger way than before the value and necessity of cultural heterogeneity. The language of totality, organicism and 'wholeness' is, as ever, pervasive; complexity, discrepancy and dissent are conceived of as elements within a whole process, so that the idea of a community of interest or process follows almost as a logical necessity. Thus Williams's account of his previous work is as follows: 'In talking of a common culture, then, one was saying first that culture was the way of life of a people, as well as the vital and indispensable contributions of specially gifted and identifiable persons, and one was using the idea of the common element of the culture - its community - as a way of criticizing that divided and fragmented culture we actually have' (19891, p. 35). The goal here is full, rather than minority involvement in making cultural meanings and the political vehicle is 'an educated and participating democracy' (p. 37); education is the key to challenging the elite monopoly of the means of communication, on which material basis cultural hegemony is reinforced. Williams is keen, by this point, to emphasize that he does not regard the common culture, which he is still advocating, as a culture freely chosen only by a minority and made artificially universal or 'common'. A concluding passage to that text is worth quoting at length:

There is some danger in conceiving of a common culture as a situation in which all people mean the same thing, value the same thing, or, in that usual abstraction of culture, have an equal possession of so much cultural property ... people, inevitably, will have different aspects of the culture ... When this is an act of choice, it is completely desirable; when it is an act of someone else's choice as to what is made available and what is neglected, then of course one objects. But it is not only that the society will be complex ... It is also that the idea of a common culture is in no sense the idea of simply consenting, and certainly not of a merely conforming, society. One returns, once more, to the original emphasis of a common determination of meanings by all the people, acting sometimes as individuals, sometimes as groups, in a process which has no particular end. (19891, p. 37) 
Williams, acknowledges, then, the diversity of individuals and groups within a culture, but not at any point different cultures. Part of Williams's shift towards a more openly nationalist emphasis in the seventies comes from recognizing the difficulty of combating the 'flattening' effect of minoritarian cultural hegemony without fragmenting one culture into several. And then, of course, if one accepts the necessity of division, the problem is how to retain the sense of solidarity that Williams's found so central to the project of an educated and participating socialist democracy.

Let us turn now to Sartre's essay 'The Burgos Trials' (1971), a work of Marxist postcolonialism which helped precipitate Williams's reorientation towards Welsh nationalism and cultural pluralism in the early-to-mid seventies. 'The Burgos Trials" ${ }^{73}$ was Sartre's interrogation of the relation between class and minority nationalist elements in a socialist praxis through the then ongoing historical example of Basque nationalism under Franco's fascist regime. In the 1977 essay 'Marxism, Poetry, Wales', Williams looked back on Sartre's piece as a sensible endorsement, against the grain of orthodox Marxism, of left-wing minority nationalism as a force for good (and for socialism):

Originally the Marxist challenge was precisely that the proletariat has no country. Whereas any good Marxist who has to preserve practice in history, even if he proposes to transcend it, has had to notice ever since that one of the most tenacious holds of the proletariat is to a country ... When it comes back to Europe, there's been such a lot of impatience among traditional Marxists that I found that Sartre writing about the Basques had for me a lot of the right sense of this, that people should determine, since it is the crucial thing for them, the conditions of their own social being. And this is the Marxist project. It is extraordinarily difficult to rule out on abstract grounds some particular project which describes itself as nationalist. I often think that is not what it is, but it is the obvious thing to call it, when it comes up in Wales or Ireland, or Scotland or Brittany. (2003d, p. 86)

We can connect elements of this account to both the early and middle periods of Williams's development. In the consciousness of place and nation we find the increasing engagement with Wales and minority nationalism, but in the more abstract phrase, 'people should determine ... the conditions of their own social being', which Williams sees as central to

\footnotetext{
${ }^{73}$ Sartre's essay appeared first appeared in Zutik, the organ of the Basque armed separatist movement Euskadi Ta Askatasuna (ETA), before appearing in the 1971/72 edition of the journal Planet: The Welsh Internationalist, translated into English from the French by the Welsh nationalist poet Harri Webb - this is almost certainly where Williams encountered it.
} 
Marxism, we find an echo of $C S$, where Williams had said: 'The struggle of democracy is a struggle for the recognition of equality of being, or it is nothing' (2013 [1958], p. 337 - my emphasis). There is a difference, though, between the abstract 'equality of being', which is more redolent of liberal universalism than any recognizably Marxist analysis, and 'determining the conditions of one's own social being', which suggests a more variegated and historical process better capable of incorporating class and geographical differences into political praxis. To simplify, it is the difference between universalism and particularism as valences of an emancipatory politics; indeed, Sartre's analysis in 'The Burgos Trials' illuminates some of the complexities inherent in this distinction.

In What is Literature?, Sartre had made the distinction between a writer's 'virtual public' and his 'real public', between the 'constant repetition in an indefinite future of the handful of [bourgeois] readers which he has at present' (2001, p. 118) and 'the sum total of men living in a given society' (p. 119). Sartre overlays a Hegelian theoretical couplet onto this formulation: to write for one's 'virtual public' is to be on the side of 'abstract universality'; to write for one's real public is to side with 'concrete universality'. Abstract universality means taking the experiences and perspectives of a minority for those of everyone in the society; the abstract is oppressive and 'unreal', the concrete real, expansive and tendentially democratic. In 'The Burgos Trials', many years later, Sartre applies these conceptual categories to the question of Basque nationalism, but now with the crucial addition of 'concrete particularism'. Sartre argues that what the militant Basque nationalists (ETA), with whom he sides unreservedly, must oppose, is 'the present unity' (1971, p. 24), the bourgeois nationalist (internal) unity of the modern roll-call of nation-states, which are the product of imperialism and class war: 'It has become clear that the present frontiers correspond to the interests of the dominant classes and not to popular aspirations, that the unity of which the great powers are so proud is a cloak for the oppression of peoples and for the overt or covert use of repressive violence' (pp. 24-25). The unity on which such state structures are erected is false and abstract, so that in each imperialist country there is the forced ideological construction of 'the same type of abstract man defined by the same formal rights - democracy - and the same real obligations, without taking any account of his concrete necessities' (p. 24). This false liberal or bourgeois unity is an abstract universality which must be opposed by the 'concrete particularism' of Basque resistance both to class oppression (by Basque and Spanish capitalists) and to Spanish cultural and political repression, both of which are arrayed on the side of abstract universality. Note that Sartre's advocacy of concrete particularism, here, as 
opposed to concrete universality, indicates a shift of emphasis in his later work, consonant with his increasing involvement in anti-colonial struggles. The universalist element is not lost, however, and returns at the close of Sartre's argument.

Sartre regards the Basque struggle, and many others like it in the post-war period, as cases of 'really existing' experiential and historical communities legitimately demanding that they not be annihilated by liberal universality: anti-colonial struggles, argues Sartre, 'could not have taken place if the so-called provinces had not had a national existence which for centuries the conquerors have tried to suppress and obstruct and conceal, but had remained in being, a fundamental tie between the people' (1971, p. 26). This is in keeping with basic existentialist ontology; Spanish abstract universality is 'essence', preceded by the concrete particularism of Basque 'existence': the real, lived, historical and practical existence of the Basque people with their own unique customs and language. A really existing and distinct cultural and linguistic heritage, however, is only one of Sartre's preconditions for minority nationalist struggle. The other is a properly Marxist one, namely colonial super-exploitation, here of the Basque country by imperialist, centralist Spain. The following selection gives Sartre's basic political-economic analysis, and his prescription for Basque emancipation:

Can we say, with ETA, that Euskadi (Spanish Basque country) is a colony of Spain? The question is important. For it is in colonies that the class struggle and the national struggle merge ... history offers no example of a conquered country which does not pay tribute to the conqueror ... Spain is committed to a veritable campaign of fiscal pillage against the Basque country. The workers are crushed by taxes ... despite appearance, the situation of the Basque worker is in all respects that of a colonised worker. He is not merely exploited, as the Castilian worker is exploited, who wages a 'chemically pure' class struggle, but deliberately super-exploited, in that he does the same work as the Spanish worker and receives a lower wage for it ... [Basque workers] have to be made to understand that in the case of Euskadi, the economic and social problems are expressed in national terms. (1971, pp. 28-31)

Note, first, that Sartre does not concede that national and class struggles can merge elsewhere than in the colonial situation; national independence is a worthy goal for the Basques because of the fact of Spanish super-exploitation, not despite or alongside it. The 'chemically pure' class struggle, argues Sartre, is waged by workers in imperialist countries, so that Basque workers are naïve to think that they can achieve socialism by means of traditional class struggle only. 
It is unclear, on the basis of 'The Burgos Trials', whether Sartre regards national selfdetermination as an end in itself, or only as the proper means to socialist ends for workers in a colonised situation. Casting doubt on Sartre's commitment to self-determination as an endin-itself is his analysis of the two main rivals to the ETA on the anti-Spanish side: the Basque Communist Party (PC) and the Basque Nationalist Party (PNV). Sartre chastises both for failing equally to recognize the necessity of both socialist and nationalist agitation in the Basque context. Of the communists, Sartre says:

PC [Basque Communist Party] regards Euskadi as merely a geographical expression. It takes its orders from the Spanish Communist Party in Madrid and takes no account of local realities. Clinging to centralism, it is socially progressive and politically conservative. It attempts to lead the Basque workers into a "chemically pure" class struggle. They forget they are dealing with a colonised, superexploited country. (1971, pp. 34)

Of the nationalists:

The PNV is also mistaken. It considers independence as an end in itself. First, they say, let us set up the Basque Republic, then we can change our society any way we like. But if this means setting up a bourgeois Basque state then, although Spanish superexploitation would be brought to an end, it would not be long before the new state fell into the clutches of American Imperialism. (1971, pp. 35)

The 'chemically pure' class struggle, then, is insufficient because it fails to grapple with the reality of colonial super-exploitation, and is too optimistic about the capacity of the centralist Spanish state to realize the essential solidarity proper to both the Basque and the Spanish workers. National sovereignty as an end-in-itself will fall through the fingers of a liberal nationalism which, ignoring the centrality of class to economic power relations, will sacrifice working-class Basque particularism to the abstract universality of U.S. economic hegemony: 'If the [prospective Basque] state retained the structure of capitalism the compradors would sell the country, the USA would rule through the local bourgeoisie, colonialism would be succeeded by neo-colonialism' (p. 35). On this account, the concept of 'nationalism for all', even when pursued by minorities, would seem to fall outside of the purview of a thoroughgoing socialist praxis.

At the end of 'The Burgos Trials', in ambiguous relation to the thrust of the larger argument, Sartre expresses a muted optimism for the idea of a universal and particularist socialist politics. He openly inquires of history whether there might be a universalist emancipation 
which operates by and through the assertion of particular interests, and whether this could in fact be the proper grounding for socialism:

A heroic people, led by a revolutionary party, has given us a glimpse of the 'other' socialism, decentralist and concrete, the singular universality that ETA rightly sets up in opposition to the abstract centralism of its oppressors. Is this socialism viable for all? Isn't it only a provisional solution for colonized countries? In other terms, can we foresee that this is the end of a stage towards the time when universal exploitations will come to an end and all men will enjoy equally a true universalism by the common operation of all particularisms? (1971, pp. 40-41)

If particularism is expressed primarily at the level of the bourgeois nation-state, it seems clear from Sartre's indictment of the PNV that the answer to this question is 'no'. But then, Sartre is emphatic in claiming that particularism in general must be pursued as part of any properly humanist political project: 'What ETA has shown us is the need of all men to affirm (including the centralists) their particularisms against abstract universalism' (p. 41). That 'the centralists' (i.e. imperialist populations) also stand to gain is a crucial feature of Sartre's account; 'to affirm [the Basque's and others'] concrete singularity', argues Sartre, 'is, as a direct consequence, to fight for ourselves as French people, for the true independence of France, which is the first victim of its own centralism' (p. 41). The French people, then, despite being nominally non-colonised, are gripped by an abstract universality of their own projection turned inwards, 'massifying' them by proxy ('today there are only French masses' (p. 41)). The French working-class, in other words, should not think that they embody universality simply by virtue of having national self-determination. What Sartre calls 'true universalism', or 'concrete universality' in What is Literature?, is the realm of all people, and since the French are not all people, they are not it. Concrete particularism for all is, on Sartre's account, the precondition of concrete universality 'for all'.

Let us now, armed with the spirit and the letter of Sartre's influential text, consider the transition from the first to the second stages of Williams's developing engagement with the politics of place. From at least Modern Tragedy (1966), Williams had been emphasising the ubiquity of colonial domination and national liberation struggles but, in keeping with the 'common culture' emphasis of his first phase, these were conceived in terms of a tragic disorder occurring within an essential totality. While Williams is cognisant of Western 
imperial domination, in this period, he is not yet conceiving of national independence struggles as autonomous struggles for regionally and culturally specific forms of emancipation. In Sartrean terms, we are still in the realm of a kind of weak abstract universality, anti-elitist but non-concrete, majoritarian but lacking consciousness of particular interests.

It is with the review of Ned Thomas's The Welsh Extremist in 1971 (the same year as 'The Burgos Trials' appeared in English) ${ }^{74}$ that new emphases on what Sartre would call concrete particularism come to the fore. The knee-jerk equation of nationalism with fascism is emphatically rejected, and thus the simple association of nationalism with anti-socialism on the traditional left. Williams foregrounds Wales as a historically oppressed, post-colonial nation, itself internally divided and experientially diverse. He makes the necessary distinction between industrial South Wales, with its 'centres of socialist consciousness' (2003k, p. 3) and 'the more enclosed, mainly rural, more Welsh-speaking west and north' (p. 3), where 'a radical emphasis on identity and community' comes through in 'the campaigns of Plaid Cymru and the Welsh Language Society' (pp. 3-4). Williams refuses, however, to see the two as incompatible and castigates the tendency of 'Many English Socialists, and many Welsh Labour Party people', to see the nationalist emphasis of the rural areas as 'a marginal or romantic irrelevance' (p. 4) praising by contrast 'the new thinking about culture which in many parts of the world has been called the New Left' (p. 4). Here Williams is cognisant of the kinds of abstract universality which can issue from socialist as well as liberal formations. Williams's opposition to the mechanical universalisms of orthodox Marxism now accompanies an acknowledgement, more pronounced in later essays, of the danger of universalising or writing one experience within a minority nation over others within that same nation i.e. the experience of the industrial South over the rural west and north. While there is still the danger of a 'falsely inward-looking, regressive, and complacent localism' (p. 3) to be avoided, Williams is now appreciative of the fact that 'some of the most powerful campaigns begin from specific unabsorbed (and therefore necessarily marginal) experiences and situations' (p. 3). Specificity 'in common' replaces, at this stage, the common culture, so that an equation can be made between diverse particularisms: 'Black Power in the United States, civil rights in Ulster, the language in Wales are experiences comparable in this respect to the

\footnotetext{
74 Thomas, in fact, was the founder of Planet, where Sartre's essay appeared; an analogy was clearly being drawn between Welsh civic nationalism and the Basque case as elaborated by Sartre.
} 
student movement and to women's liberation' (p. 3); this is not so far away from Sartre's 'common operation of all particularisms'.

What began as the necessity of a participatory common culture becomes, as of the early seventies, the necessity of defining a distinct culture and a distinct cultural identity. Now, while the achievement of a common culture had not seemed inherently difficult to Williams, since what was preventing it was mainly the 'external' imposition of abstract universality, the achievement of a distinct culture appears to face greater internal challenges. In the essay 'Welsh Culture' (1975), Williams rakes over the coals of Welsh national self-definition, focussing on the difficulty of arriving at a settled conception of Welsh culture within a modern commercial society, and with a past and present of colonial domination and hard economic pressure to incorporate, unevenly, into that image; the difficulties, in short, of a culture which is not common. 'Where is it now, this Wales?' asks Williams, 'Where is the real identity, the real culture?' (2003j, p. 5). The goal, as for Sartre, is to foreground that which is concrete against that which is abstract, but this is a prodigious feat in the face of a history of colonial exploitation and cultural repression. Williams notes the temptation to 'reach for our fancy dress' (p. 5), to 'indulge' culture only on 'high days and holidays: not an ordinary gear but an overdrive' (p. 5), or to see culture as a commercially-oriented exercise in selective preservation, 'a resort and a festival, both meticulously and distinctively Welsh' (p. 7). Wales, argues Williams, is expressing a post-colonial cultural pattern in which distinctiveness is cultivated negatively and with an oppositional fixation on painful historical processes of formation, lacking the expansiveness and confidence in the future necessary to achieve effective cultural self-definition:

There is a very skilful kind of accommodation, finding new ways to be recognised as different, which we then actively cultivate, while not noticing, beyond them, the profound resignation. These are some of the signs of a post-colonial culture, conscious all the time of its own real strengths and potentials, longing only to be itself, to become its own world but with so much, too much, on its back to be able, consistently, to face its real future. It has happened in many places. Real independence is a time of new and active creation: people sure enough of themselves to discard their baggage; knowing the past as past, as a shaping history, but with a new confident sense of the present and the future, where the decisive meanings and values will be made. (2003j, p. 9)

Williams's analysis of the problematics of Welsh cultural experience bears a close resemblance to Sartre's formula for dialectical reason, to which coin there was two sides: a) 
the acknowledgement of objective historical processes and their determining influence, and b) the awareness of human action itself as the fundamental shaping force of history; intentional human action proceeding on the basis of both was what Sartre called praxis. Welsh culture, in Williams's analysis, refuses to 'discard the baggage' of its own history, to take practical responsibility for the historical past and future. It is as though Welsh culture has achieved a passive version of the objective component of dialectical reason, recognising the past 'as a shaping history', but has failed to achieve the subjective, creative element, the art of 'knowing the past as past' so that it can be in the present and future that 'the decisive meanings and values will be made'. In 'Welsh Culture' something similar to what Williams called, in the review of The Welsh Extremist, a 'falsely inward-looking, regressive, and complacent localism' appears in the form of the tourist version of historical memory, a sublimation of post-colonial anxieties substituted for the production of new meanings in the present. We might here draw a fourth pairing from Sartre's four-term combinatory (concrete, abstract, particularism, universalism) and say that Williams's analysis points to the production of abstract particularism, the mistaking of a historically fixated simulacra of a culture for the real, lived culture of an existing community.

The goal of cultural self-production, as I am framing it here using Sartrean terminology, may be theorised as the avoidance of both abstract universality (false unity) and abstract particularism. The first barrier, abstract universality, is also the most politically urgent, and it is against such false unity that Williams rails in 'Are We Becoming More Divided?' (197578). There Williams provides a basic sense of what minority nationalism is for him, as an antidote to the received view that such projects create only spurious and harmful divisions:

In Scotland and Wales we are beginning to find ways of expressing two kinds of impulse that are in fact very widely experienced throughout British society. First, we are trying to declare an identity, to discover in fact what we really have in common, in a world which is full of false identities ... second, but related to this, we are trying to discover political processes by which people really can govern themselves - that is, to determine the use of their own energies and resources - as distinct from being governed by an increasingly centralised, increasingly remote and also increasingly penetrating system: the system that those who run, for their own interests, have decided to call 'Unity.' (2003a, p. 188) 
The search for concreteness announces itself in phrases like 'what we really have in common', that is, an underlying cultural experience ${ }^{75}$ and 'by which people can really govern themselves'; what is 'real' is opposed to what is abstract, and what is abstract is falsely called 'Unity' by those who stand to gain from traditional and habitual configurations of unity and division. But other false unities, albeit smaller ones, are close at hand, whether in the form of 'a weak kind of romanticism' making 'the Scots and the Welsh more different from the English than they really are' (p. 188) or the elision of, as Williams reiterates, 'the deep differences between industrial South Wales, rural North and West Wales, and the very specific border country from which I myself come' (p. 188). For Williams, the solution to the problem of cultural self-definition cannot lie in 'inventing a pseudo-historical or romantic Welshness' (p. 189) i.e. the replacement of abstract universality with abstract particularism. The solution, Williams argues, is a new unity: 'We get past it by looking and working for unity in the definition and development of a modern Wales, in which the really powerful impulses - to discover an effective modern community and to take control of our own energies and resources - can be practically worked through. That is what I mean by saying that the nationalist movements, while they can be seen from one position, as working to divide, must be seen from another position as working to unite' (p. 189). Again, the comparison with Sartre is instructive; if Wales is to be the site of a new unity, it will be a unity of acknowledged differences, a universality composed of free particularisms. ${ }^{76}$ The crucial thing is self-determination, but the focus on an inclusive form of unity returns us to the emphasis of the 'common culture'; solidarity doesn't depart the argument, and the 'work' of cultural definition remains a common work or nothing at all. The difference by this point is that Williams no longer sees it as necessary to corral conflicting viewpoints into a single cultural matrix, however tolerant and democratic the process of doing so may be; social systems falling beneath particular locational signifiers may be comprised of many different, distinct cultures which either agree or refuse to co-operate in common projects and formations.

Williams's trajectory up to the early-seventies is thus defined by the move from the common culture to the (hopefully) co-operating plurality of concrete particularisms (concrete or 'effective' communities):

\footnotetext{
${ }^{75}$ Recall that Sartre, similarly, had claimed the existence of a concrete Basque cultural experience.

${ }^{76}$ Specifically, the industrial South, rural West and North and the border country. The same would be true, says Williams (2003a), of the English regions, if they had the definitions to hand, so that 'a nationalist movement isn't the only way, often isn't the way at all, to work for these things' (189).
} 
Once you are not controlled, in advance and systematically, by others, you soon discover the kinds of co-operation, between nations, between regions, between communities, on which any full life depends. But it is then your willing and not your enforced co-operation. That is why I, with many others, now want and work to divide, as a way of declaring our own interests, certainly, but also as a way of finding new and willing forms of co-operation: the only kind of co-operation that any free people can call unity. (2003a, p. 190)

Cultural co-operation, here, is an act of 'willing', carried on by a 'free people'. A prerequisite of such 'sovereignty-pooling' is that a given community 'is not controlled, in advance and systematically, by others'. Politically, Williams gives us little to object to; there is a nonetheless a conceptual tension between this broadly liberal, 'contractual' analysis and Williams's insistence, in his aesthetic essays and elsewhere, that freedom is unthinkable 'except in terms of its specific social production' (1989b, p. 91). Is Williams indulging in what he will later call 'the bourgeois concept of the individual, who exists, as it were, free and formed, before he decides to enter into relationships, associations or contracts, or, in the extreme case, to refrain from doing so or to enter into as few as he can' (1990b, pp. 257258)? Here, of course, Williams is speaking of communities rather than individuals, but it was clear from his analysis of Welsh culture that communities are no less formed and aligned by social-historical forces than the human beings who comprise them. The way in which Williams parses the tension between material-historical formation and cultural selfdetermination cannot be considered apart from the issue of class and socialist practice within minority nationalism. Let us now, in approaching the third period of Williams's engagement with the politics of place, consider his increasing concern with objective (especially economic) forces in the constitution of 'free' or concrete cultures, as well as the question of cultural elements which remain intractably obscure to experience. In doing so we shall also fully reckon with Sartre's insistence that minority nationalism must incorporate the class struggle to achieve concreteness.

\section{Dialectical materialism and the politics of place}

Williams's search for cultural self-determination, focussed through the prism of Welsh minority nationalism, leads him to the view, as of the mid-seventies, that true unity is achieved through the mutual operation of distinct particularisms, so that D. Williams (2003) is correct in arguing that, for Williams, 'plurality forms the basis for a new sense of Welsh 
communality' (xxxv). Recalling that, for Williams, cultural identity is based on the practice of self-defining communities establishing the meaning of their own experiences, free from imposed abstractions, we can say that the plurality and diversity which Williams advocates has experience as its primary site and grounding; the cultures which will emerge from a system of self-determining politico-cultural units will be 'concrete' precisely because the full complexity of diverse, 'placed' experiences elude unitary, 'abstract' definitions. Diverse cultural interpretations and 'whole ways of life' co-exist in the combinatory of a wider cultural signifier (say, 'Wales'), entering into various and shifting configurations without being overwritten or obscured by other terms (in this case, the impositions of abstract universality/particularism). By the mid-to-late seventies, Williams has resolved the problem faced by the 'common culture' argument, of how to incorporate heterogeneity without sacrificing solidarity, by incorporating plurality into a 'single-system' approach, in keeping, at least at the level of rhetoric, with the notion of totality; we can achieve unity through the free configuration and reconfiguration of distinct cultural units on the basis of what we might call 'syntagmatic' cultural relations, which is to say the simultaneous presence of different cultural forms within a wider social experience.

But how do we incorporate those elements of culture which either do not announce themselves to experience, or do so unreliably? While it is right to attribute to experience a privileged position in Williams's cultural schema, based as it is on self-definition, he was nevertheless acutely aware of the importance of incorporating knowledge of processes which are less available to experience. This, after all, was the central kernel of the realist problematic, which Williams regarded as having been correctly posed but unresolved by Lukacs: how to portray the full complexity of life under capitalism in such a way as to capture the power relations and structural causalities immanent to modern industrialised society? The problem is one that Williams described as being between 'substance and system' i.e. between concrete lived experience and objective structures. As of his 1980 review of Lukacs's Essays on Realism, Williams did not believe that a reliable literary method had been found for 'representing working class life and at the same time introducing the necessarily different consciousness of the objective conditions and wider historical movement within which the men and women live and act' (New Society, 1980, Nov 20, p.382). Williams thought that a 'different consciousness' would be required for untangling objective reality from lived experience, and that this would be central to apprehending or representing the real lives of working-class people. At the level of epistemology, Williams 
found something akin to this 'dual consciousness' in Sartre's late elaboration of dialectical reason, which aimed at precisely such a synthesis of objective historical analysis and 'interiority' or lived experience. If working-class life is also, and fundamentally, the life of a people in a place, it remains for socialists to bolster the free self-definition of effective communities with objective analysis of those material structures which are difficult to explore from within a stance of pure 'interiority'.

Early precedents for Williams's thinking about the synthesis of substance and system express an acute anxiety about its very possibility. Matthew Price in Border Country (1961), a university lecturer born in Wales but working in London, is the archetypal case of a psychological 'wedge' between the dual consciousnesses required for real social representation. Struggling to resolve the tension between the cold detachment of formal analysis and the lived and placed experience of a community to which he feels a deep but time-frayed attachment, Price, on returning to Wales to visit his dying father, reflects on his epistemological dilemma:

He was working on population movements into the Welsh mining valleys in the middle decades of the nineteenth century. But I have moved myself, he objected, and what is it really that I must measure? The techniques I have learned have the solidity and precision of ice-cubes, while a given temperature is maintained. But it is a temperature I can't really maintain; the door of the box keeps flying open. It's hardly a population movement from Glynmawr to London, but it's a change of substance, as it must also have been for them, when they left their villages. And the ways of measuring this are not only outside my discipline. They are somewhere else altogether, that I can feel but not handle, touch but not grasp. (Williams, 2010, pp. 56)

The word 'substance', which actually appears in this passage, is used in a similar way to 'concrete' in Williams's (and Sartre's) writing, to mean lived, particular, or experienced. Moving to London isn't just a 'population movement', an objective fact, but a 'change of substance', an experiential shift. The precision measurements of his research fail to capture this; the tools required to measure the experience are 'somewhere else', that is, in a specific place where he is not, so that he can somewhat ephemerally 'feel' them (having grown up there) but no longer 'handle', 'grasp' or know them as matters of continuing practical relevance. Price is the paradigmatic 'returning native' in Williams's oeuvre, but he does not return with the 'concrete' experience of a different, English culture. While Price speaks disparagingly of a more atomized, distant set of social relations in England (p. 5), his anxiety 
is provoked not by the contact of Welsh culture with English culture, but of lived experience with abstract analysis. England, in fact, operates largely as a metaphorical analogy with abstraction itself, the antithesis to the role that Wales plays, in the 'common culture' essays, as the site of a relatively autonomous, self-defining cultural productivity based in experience. D. Williams (2003) argues that, in Border Country, this tension manifests itself most immediately as a 'crisis of language' (xix), of communication, as Matthew struggles to 'readapt' to the speech patterns and received meanings operative in his place of origin. 'The relationship between the language of intellectuals and the inherited language of one's "native country" is a recurrent theme in Williams's theoretical and fictional writings' (xxiii), he suggests; we have consistently observed Williams's impatience with intellectuals who impose abstract theories onto more 'concrete' interpretative procedures. Such linguistic difficulties can provoke stark political tensions, as in another example D. Williams draws from Williams's later fiction: 'In a significant and revealing moment in the novel The Volunteers, Evan castigates a technocratic intellectual for having "nothing to say for us. You have plenty to say to us. You beam in from another world"' (xxiii). Again, we are returned to Lukacs and the perennial problem of condescending to people lacking adequate consciousness of exploitation. And yet, like Lukacs, Williams considers it a genuine problem of literary representation that the wider structures determining so much of working-class life elude the eye of the realist narrator.

A passage from the start of 'Welsh Culture' evocatively announces the problem of what we might call 'cultural objectivity':

So if you say Welsh 'culture' what do you think of? Of bara brith and the Eisteddfod? Of choirs and Cardiff Arms Park? Of love spoons and englynion? Of the national costume and the rampant red dragon? All these things are here, if at different levels and in different ways. But over and above them is another culture. Not the alien Saxon, who belongs, in truth, with the fancy dress ... Taking culture in its full sense you would be speaking of something quite different: of a way of life determined by the National Coal Board, the British Steel Corporation, the Milk Marketing Board, the Co-op and Marks and Spencers, the BBC, the Labour Party, the EEC, NATO. But that's not Welsh culture. Maybe, maybe not. It's how and where most people in Wales are living, and in relation to which most meanings and values are in practice found. Depopulation, unemployment, exploitation, poverty: if these are not part of Welsh culture we are denying large parts of our social experience. (2003j, p. 5)

What makes the narrow 'customs and costume' definition of culture seem painfully narrow is the totality in all of its expansiveness, the full range of interconnected material, political, 
economic and institutional forces which contribute to a 'way of life'. Williams's case, that we should broaden our definition of Welsh culture, appears unarguable, but when he refers to 'denying large parts of our social experience', he is begging the question. For unless the modifier 'social' is supposed to detach 'experience' from the issue of consciousness entirely, one would be hard pressed to argue that 'NATO', for example, announces itself to experience, still less the experience of a place, in anything but the most distant and abstract manner. What makes Williams's argument sound faintly idealistic is the fact that the larger material structures governing much of what signifiers like 'EEC' and 'National Coal Board' refer to are deeply resistant to 'social experience' of the lived or 'concrete' kind. Like Lukacs's unanswered challenge, it alerts us to the necessity of abstraction in grasping the totality, which appears in Sartre's work as the objective, historicizing side of the coin of dialectical reason, and in Williams's as the 'different consciousness' required to achieve full social representation. It is primarily from the late seventies into the eighties that Williams's writings on the politics of place begin to seriously incorporate this acknowledgement, although from at least the 'common culture' pieces it was present in the need for an 'educated and participating democracy', which means among other things a democracy capable of abstract or formal analysis.

The central problem which 'The Importance of Community' (1977) addresses is why it has been so difficult to make the 'common culture' argument for socialism, namely that the values of close-knit, working class communities ought to be 'extended towards a political movement which should be the establishment of higher relations of this kind and which would be the total relations of a society' (2003h, p. 179). Such efforts, argues Williams, underestimated 'systemic obstacles' (p. 181) centered around the inscrutability of structures of power and property, and the concomitant necessity of 'the politics of abstract analysis' ( $p$. 182). What the general shift towards abstract analysis on the left betokened, Williams argues, is 'the perception that there were now fundamental and systematic historical changes, above all in the mode of production but carrying with them virtually every other kind of institutional change ... which put the basic elements of our social life beyond the reach both of direct experience and of simple affirmation, affirmation followed by extension' (p. 182). What Williams regrets in the necessary movement towards abstract analysis is the manner in which community was made to seem, and sometimes actually was, the antithesis of both a globalizing world and the paradigms now required to understand it: 
Certain things which are now profoundly systematic, which happen in complex ways over very large areas, and which we have had to understand in ways that, in comparison with the simple affirmatives extended from experience through community to the making of new societies, seem and indeed often are distant and dehumanized: the apparent opposite of community. The system of ownership, for example, in the modern economy, which cannot be observed, which has to be consciously discovered. (2003h, p. 182)

We are a long way, in the foregrounding of that which 'cannot be observed', from the skepticism of TLR (1961), where Williams approached a semi-Kantian, anti-realist epistemology. ${ }^{77}$ Williams does not cede too much ground to abstract analysis in 'The Importance of Community', however, insisting that a left politics which negates experience cannot simply replace one which affirms it. It is 'of course' (2003h, p. 183) right that 'a modern community simply could not be built in the model of these simpler and earlier ways of life' (p. 183) and that 'the objections being made in the phase of this revival of community and nationalist thinking ... have to be taken at their full and proper weight' (p. 183). However, Williams argues, 'if that negative politics is the only politics then it is the final victory of a mode of thought which seems to me the ultimate product of capitalist society ... a mode of thought which really has made relations between men into relations between things or relations between concepts' (p. 184). This, of course, recalling Williams's discussions of Lukacs, would be reification, the dehumanizing and naturalizing logic of the market and of abstract universality. Minority nationalist movements, argues Williams, are restoring to the necessary but 'negative' procedure of abstract analysis 'the sense of what any of this liberation is for, the sense of what the struggle would be able to attain, the sense of what human life would be' (p. 185). They point, in other words, towards a positive project to identify a non-reified, non-alienated way of life in service to human needs and aspirations, discoverable in experience; ' a reconnection inside the struggle, including the negations, but also the sense of an objective which has the possibility of affirmation' (p. 185).

It is important to note that Williams, following Sartre's 'interiority', does not see objective knowledge as an addition to self-knowledge, but as internal to it. Self-knowledge of a culture or a community cannot be achieved without incorporating those elements of culture, which can be absent from the 'text' (and indeed the territory) of experience. Thus in 'Remaking

\footnotetext{
${ }^{77}$ For example: 'The new facts about perception make it impossible for us to assume that there is any reality experienced by man into which man's own observations and interpretations do not enter' (2011b [1961], p. 38). Even here, however, Williams provides a realist caveat: perception acts not upon objective reality, but on reality as 'experienced by man'.
} 
Welsh History' (1980d), commenting on the work of the Welsh historian David (Dai) Smith, Williams approvingly cites "the crucial description of the nineteenth-century "Imperial" and "Atlantic" economy, in iron and then coal, which is the true historical matrix. That wealth and power, that scale of world-economic significance, is as much to be remembered as the subsequent depression, for it is from the political interactions and effects, in each period, that the complexity of culture derives' (2003e, p. 71). Again, Sartre-esque phrases such as 'the true historical matrix' would have felt utterly out of place in TLR. Culture as it really is, Williams suggests, in its full historicity, cannot be understood without this information. The combination of subjective experience in a place, including memory, with objective, 'learned' information creates a new kind of knowledge and new affective and personal resonances. As an example, Williams recalls his father growing potatoes: 'But I just did not know the complex history of potato-setting, and its formal and informal labour obligations as traced by David Jenkins' (p. 71). The result, far from overwriting experience with cold abstraction, is an unlocking of cultural identification:

The personal memory, local and specific, is then suddenly connected with the history of thousands of people, through several generations. As the particular and the general, the personal and the social, are at last brought together, each kind of memory and sense of identity is clarified and strengthened. The relation between people and 'a people' begin to move in the mind. (2003e, p. 71)

This, of course, was precisely the object of the perspective of totality, as elaborated for realist literature in $T L R$, and the reference point of the affective complex known as a 'structure of feeling'. Where the general overwrites the particular, on the left, it polarizes 'an idea of the proletariat against the idea of community' (2003e, p. 72), an anachronistic Marxist temptation ('the proletariat has no country') against which Williams had endorsed Sartre on the Basques. It is, of course, tautologically true to say that 'the proletariat has no country', since 'the proletariat' is a term originating in abstract analysis, at the level of absolute generality; it is true, in that it refers to the universal, borderless reality of exploitation, but not to reality as experienced, day-to-day, by the majority of working people. ${ }^{78}$ Qua Sartre, we would have to say that the true sentence 'the proletariat has no country' does not, at the level of its simple elaboration, satisfy the requirements of dialectical reason. But neither does the simple (bourgeois) assertion that nation or community are what is 'real' in people's lives, while class is a mere abstraction or overlaid theory. What both Sartre and Williams's positions imply is

\footnotetext{
${ }^{78}$ In the structurally identical sentence 'homo sapiens has no country', the tautology is evident.
} 
that praxis is not achievable except for that social actor who experiences her interiority objectively; as historically and materially conditioned and conditioning (thus Sartre's assertion that the national and the class struggle are inextricable).

Ellen Meiksins Wood (2003) describes capitalism as a mode of production in which the economic and the political are separated out, both literally and ideologically, because the extraction of a surplus is carried out through economic means, in contrast to the direct coercive force used in, for example, the feudal system. The appropriating class thus establishes a certain distance, in reality and in appearance, between its own activities and the civic and cultural lives of the working majority, so that while continuing to exert social hegemony, it becomes spectral, its character as a class opaque. This raises severe problems for the socialist novelist who wishes to set his action in a well-observed locale, as Williams acknowledges of his own fiction in Politics and Letters (1979):

The class relations in Border Country come through literally at the end of the line, in the way the railway company tries to treat the workers after the General Strike through its remote telegrams and notices. The capitalist world is not a presence, it is never directly introduced in the novel. If it had been, I would have felt in a quandary. (2015, p. 284)

Williams doesn't explain the nature of the quandary; we can assume, on the basis of later essays such as 'Region and Class in the Novel' (1985c), that it consists in the extreme difficulty of representing 'the capitalist world' i.e. large-scale systems of economic oppression within the narrative parameters of a local experience. In that essay, Williams foregrounds the problem of distance and opacity: 'The local class enemy is usually the manager, or more broadly the local petty bourgeoisie. The dominant bourgeoisie is less visible and indeed is often, at this stage of capitalist development, physically absent' (1985c, p. 237). We are returned to the Lukacsian problematic, with Williams even noting the irony 'that the best historical fiction about the Welsh working class has been written by a sympathetic outside observer, who could read as well as experience the history: Alexander Cordell (see The Rape of the Fair Country (1959)' (p. 237). This is ironic, but only from the received nationalist perspective that close personal experience is equal to 'better understanding'; from the dialectical perspective, it follows that someone with a grasp of the material history of a place might write better historical fiction than someone with intimate knowledge only of the local present. That Williams endorses the quality of being someone 'who could read as well as experience' is redolent of that life-long commitment to popular 
education, what was called 'cultural revolution' in the sixties, as the enabler of the perspective of totality (or of dialectical reason). Historical literacy, then, as one way of evading abstract particularism.

D. Williams (2003) correctly notes that Williams's advocacy of cultural pluralism does not ally him with postmodern theorists of cultural 'hybridity': 'Williams's pluralism always involves a simultaneous gesture towards a community of belief and action which is hardly compatible with the cultural and political relativism of postmodernism' (xliv-xlv). Against the temptation to read Williams's firm rejection, in Sartrean fashion, of cultural 'essences' as a 'postmodern' impulse, we must recall that postmodernism has no monopoly on antiessentialism; it is also a hallmark of historicizing but non-relative forms of thought, among which Williams's must be counted. The key distinguishing feature between Williams and postmodernism, I would argue, is his commitment to philosophical (as well as literary) realism, the maintenance in theory of objects beyond consciousness, to which our access may be indirect and mediated. The purpose of education, then, of becoming historically and economically literate, can be neither the discovery of combative essences with which to fight the essences wielded by imperialism, nor the overwriting of experience and interiority with determining systems articulated in the language of science and Enlightenment. Such nondialectical logics, as Williams's analysis in 'Wales and England' (1983) suggests, have as their end-point failed political strategies:

At its most negative, this has led, on the one hand, to archaic or residual types of nationalism, in which a received, traditional and unproblematic identity has been asserted as overriding all those modern economic and political relations which are in fact inevitable and determining. It has led, on the other hand, to pseudo-modernist rejections of the specificities of Welshness and the Welsh situation, in which the confident imperatives of the incorporation - a transforming Liberalism, a redeeming and transforming Labourism - are repeated long after they have practically failed, both at the centre and in Wales itself. (2003, p. 23-24)

Liberalism and Labourism, in this schema, are the abstract universalities of Welsh antinationalism, while essentialising forms of Welsh nationalism play the role of abstract particularism. Nationalist false consciousness figures in the 'ideological notion ... that Wales is classless, because we do indeed have easier immediate ways of speaking to each other' ( $p$. 25), so that a cultural history of solidarity, misinterpreted by essentialism, could now be 'a powerful barrier to that practical communalism which requires difficult transformations of political and economic institutions and relations, rather than friendly and informal 
accommodations to them' (p. 25). And yet Wales, argues Williams, with its complex experience of both socialist and nationalist politics within a context of historical oppression, may yet be closer than England to that concrete particularism (and thus concrete universality) which Sartre identified and advocated for the Basques: 'The Welsh of course, have been inside these cross-pressures for much longer than the English. And as a result we have had to learn that we need to solve the real contradictions between nationality and class, and between local well-being and the imperatives of a large-scale system. Consequently, we may be further along the road to a relevant if inevitably painful contemporary social consciousness' (p. 25). Wales, then, as a potential locus for the synthesis of substance and system.

I have argued that the shift from the first to the second phases of Williams's development was the movement from a kind of democratic monoculturalism (the common culture) to an advocacy of cultural pluralism which, at least in theory, evades ephemerality ${ }^{79}$ by better reflecting the diversity of real experiences; the stability of the plural system is to be found in its correspondence with really existing differences between nationally 'co-habiting' ways of life. This is cultural diversity at the level of the syntagm, the co-presence of cultural units within the national text/territory. But the development from the second to the third phases of Williams's development expresses a problem which is not captured by the monoculturalismpluralism antagonism, but which instead refers us to presence/absence relations within the cultural totality i.e. between those which are routinely experienced and those which are not. The elements which are not experienced are most often those which relate to the larger, extraterritorial and structural properties of class relations in developed capitalism. Moreover, the experienced and the non-experienced elements of a culture are by no means independent of one another; larger structural relations limit and exert pressure on the symbolization of experience, while received definitions are used both to solidify and to challenge existing structural relations. ${ }^{80}$ The perspective of totality must incorporate both axes, as well as their mutual interrelations and interdependencies, to be properly 'total'.

'The Culture of Nations', a chapter in Williams's last book-length work of social criticism, Towards 2000 (1983), strongly echoes Sartre's 'The Burgos Trials' and is perhaps the best

\footnotetext{
${ }^{79}$ Or, as D. Williams (2003) puts it, 'a self-frustrating libertarianism' in which 'the "nation" is regarded as a vessel in which a limitless plurality of cultures may co-inhabit and coexist with equal validity' (xxxiv).

${ }^{80}$ See Chapter Three for a fuller discussion of these processes in Williams's writing.
} 
expression of Williams's mature, totalizing view. Like Sartre, Williams conceives of the dominant forms of nationalism and the nation-state as weapons in the arsenal of class hegemony. 'It is an evident historical fact', says Williams, 'that the processes of political combination and definition are initiated by a ruling class: indeed to say so is virtually tautologous. The building of states, at whatever level, is intrinsically a ruling-class operation' (2003g, p. 192). From this proceeds the traditional opposition between socialist radicalism and minority nationalism, but this sits uneasily, Williams notes, with the fact that 'what has been most remarkable in the twentieth century has been the successful fusion of nationalism and political revolution, including armed struggles, in many other parts of the world, from Cuba to Vietnam' (p. 194). There is clearly, on this account, a bedrock of reciprocity between the two which makes itself felt in some historical situations (colonies), and not in others (the metropoles). Social democrats imbibe the existing national definitions and this, combined with their antipathy to social revolution, exacerbates the problem:

For what [the social democrats] will not challenge, except in selected marginal ways, is capitalism itself. Yet it is capitalism, especially in its most developed stages, which is the main source of all the contemporary confusions about peoples and nations and their necessary loyalties and bonds. Moreover it is, in the modern epoch, capitalism which has disrupted and overridden natural communities. (2003g, p. 195)

It is capitalism, in other words, which overrides concrete particularism in favour of abstract universality. In the modern period, moreover, the use of nationalist rhetoric by the ruling classes veils an ever increasing commitment to international capital flows; what remains of 'national' efficacy is channeled ever more narrowly towards maintaining a 'socially organised and socially disciplined population' (pp. 196-197), subjects of a capitalism (we now call it neoliberalism) ever more detached from the real lives of people in places. Thus is continually overridden 'what might be called the true nation, the actual and diverse people' (p. 197). An atomizing commercial culture, meanwhile, cleaves apart the social connections which might have restored a sense of the 'nation' concomitant with solidarity. Perverse symptoms then abound, such as the counter-intuitive fact that " "nationalization" is not perceived as connected to "nationalism" ...while a transnational strategy, pursued even to the point where a national economy loses heavily within unrestricted competition, is by its structural retention of the most artificial national images perceived as the "patriotic" course' (p. 197). Such, argues Williams, are the 'intolerable confusions' (p. 199) of the modern nation-state. 
Williams's late critique of the nation-state as a disciplinary technology of the ruling class is by no means a restatement of the traditional socialist complaint against proletarian division. He remains fully committed to the politics of place, and to forms of common identity which incorporate particular forms of 'placed' life: 'It is by working and living together, with some real place and common interest to identify with, and as free as may be from external ideological definitions, whether divisive or universalist, that real social identities are formed' (2003g, p. 201). Bringing such a condition about, however, will be as much a matter of scale, and thus of practical organisation, as the 'free' formation of identity. 'The nation-state, in its classical European forms', argues Williams, 'is at once too large and too small for the range of real social purposes' (p. 201). The formulation that follows attempts, in two strokes, to solve the problems laid along what I have described as the presence/absence axes of cultural self-definition. In the first instance, Williams's analysis recommends the restoration of a measure of substance to the empty vastness of the modern nation, which is 'too large, even in the old nation-states such as Britain, to develop full social identities in their real diversity' ( $p$. 201). Since no workable combination of meanings and definitions is possible in such states, Williams suggests that 'a large part of the now alienated and centralized powers and resources must be actively regained, by new actual societies which in their own terms, and nobody else's, define themselves', and further, that 'all effective socialist policies, over the coming generations, must be directed towards this practice' (pp. 201-202). In order for the real co-existence of distinct 'ways of life' to be achievable under the signifier of a selfdefining society, then, political relations must be reduced to a scale concomitant with lived experience.

The recalibration of borders in line with lived experience does not, of course, solve the problem of the epistemological opacity or 'absence' of structural class relations in developed capitalism. Williams, now fully aware of these difficulties, incorporates them into his proposed solution:

At the same time it is obvious that for many purposes not only these more real societies but also the existing nation-states are too small. The trading, monetary and military problems which now show this to be true, and which have so heavily encroached on the supposed 'sovereignty' of nation states, would not disappear in any movement to placeable communal self-management. (2003g, p. 202)

While Williams does not claim that these structural issues are insurmountable, he insists that 'we cannot say, at any level, that these placeable self-managing societies could be 
"sovereign". Even to say that they could be "autonomous" is taking a very limited sense' (p. 202). The determining force of class relations here asserts itself, returning us to Sartre's warnings about U.S. neo-imperialism to the liberal Basque nationalists. It also recalls Williams's critique of the artist who falsely believes himself free from social determination; the Sartrean model of subjective apprehension of objective determinants which Williams moved towards in his aesthetic theory, is also perceptible in his sharper reckoning with the objective determinants of a nation's range of action and power of self-definition. What is wanted, argues Williams, is not autonomy per se, but particularism as a principle and an ideal: 'we have to explore new forms of variable societies, in which over the whole range of social purposes different sizes of society are defined for different kinds of issue and decision' (p. 202). This 'variable socialism' (p. 203) would replace the current system of localities, regions and nations, all subject to a centralized power, with 'an absolute refusal of overriding national and international bodies which do not derive their specified powers directly from the participation and negotiation of actual self-governing societies' (p. 203). Communities would interact on the basis of 'rooted contacts and mobilities' (p. 203), on selective issues and projects, 'negotiated from real bases' (p. 203). Such a system will be needed, argues Williams, or else 'we shall be condemned to endure the accelerated pace of false and frenetic nationalisms and a reckless and uncontrollable global transnationalism' (p. 203); in short, the contradictions of late capitalist globalization.

It is far from a perfect model. Insufficient emphasis is placed on the fact that Williams's selfgoverning societies would presumably have socialist economies; if they did not, it is difficult to see how direct democratic fluidity of political borders could contend with the hard logic of capital accumulation in the long run. Williams's vision may, in this sense, be putting the cart before the horse, solving a specifically capitalist cultural problematic by means that would require the revolutionary emergence of socialism before they could be instituted. But he does call it 'variable socialism' and makes it clear in 'The Culture of Nations' that capitalism is the main problem and must be overthrown. The absence of revolutionary rupture nevertheless gives the impression of a smooth or evolutionary progress towards realistic cultural and political forms. The missing break or rupture with capitalist social relations is then a missed opportunity to discuss what that rupture itself might mean for the nation-state and the selfdefinition of effective communities; we might imagine this as a development of the themes of Modern Tragedy for the politics of place. As we shall see in the next chapter, Williams is not 
a pacifist; violence, as part of an expansively defined revolutionary process, is by no means disavowed in his work.

It may be that Williams's 'variable socialism' resolves the 'common culture' problematic in favour of 'substance'. A system of fluid social scales, aligned with the real diversity of experiences and interests, it would free ordinary people, theoretically, from imputed, unitary and false definitions of nationhood and community. However, the problem of cultural absence, the opacity of structural relations ('system') is more stubborn; it remains to be explained how class relations are to be made present at the level of consciousness, in other words, how dialectical reason/the perspective of totality are to be produced and practiced psychologically. If this is not a requirement of Williams's schema, it remains unclear why people would opt for a variable socialism rather than a variable capitalism. For while it is in principle reasonable to assume that democratic societies operating at variable scales would be free to establish systems of common, democratic ownership, this is only a formal freedom; the inclination and capacity to do so, if we take Williams and Sartre seriously, will depend on structural class relations appearing to consciousness as fully incorporated features of their social identities. If praxis is not to be the preserve of a philosophical or political elite, the question of under what conditions an entire people may become possessed of self-definitions which are neither imputed ('socialism from above') nor false (bourgeois), neither abstractly universal nor abstractly particular, must be answered. This is the question of hegemony; it is to Williams's reconceptualization, in the seventies, of Gramsci's ubiquitous concept that we now turn. 


\section{Chapter Three}

\section{Williams and Gramsci: Culture, Submission, Emergence}

\section{An outline of Williams's engagement with Gramsci}

There are barriers to assessing the influence of Gramsci on Williams with which we did not have to contend in the preceding chapters. There it was possible at the outset to provide summaries of Williams's interactions with the texts of Lukacs and Sartre spanning multiple decades, and to map these over developments in Williams's thought. Due primarily to what David Forgacs (1989) calls the 'fragmentary and posthumous' (p. 71) nature of Gramsci's writings and their publication in English, there is no significant mention of Gramsci in Williams's work until 'Lucien Goldmann and Marxism's Alternative Tradition' (1972), published a year after the English edition of the standard Selections from the Prison Notebooks of Antonio Gramsci (1971). A less adequate selection, The Modern Prince and other Writings (1957) had appeared much earlier; Williams may well have read this but, as Forgacs notes, the book 'did not sell well and had relatively little resonance at the time beyond a small group of people actively interested in Marxist politics' (1989, p. 73). Of course, Williams may be considered such an interested person, but while Gwyn A. Williams named him as someone to whom comparison with Gramsci might be made as early as 1960, I think Forgacs is right to describe Williams and Thompson's work in this period as an indirect brokerage of Gramscian themes: 'It was not so much a question of Williams or Thompson having read and been influenced by Gramsci in their own work at this stage ... it was that their work on culture provided a framework, an intellectual space, within which Gramsci, or a certain side of Gramsci, could be made visible and readable' (p. 74). The more direct brokerage came from Anderson and Nairn, whose 'theses' explicitly referenced and utilised Gramsci, and we have already noted Anderson's foregrounding, in the mid-sixties, of what Williams would later describe as Marxism's 'alternative tradition'. 81

While I will read elements of Williams's earlier work, in particular parts of The Long Revolution and Modern Tragedy, as broadly Gramscian in orientation, I will refrain from

${ }^{81}$ See p. 193. 
claims of direct influence. It is only with the seventies that Gramsci's influence becomes explicit and indeed central to Williams's development. Even in this period of heightened interaction, however, Williams is not dealing with specific texts or passages (although Williams had referenced The Prison Notebooks in the 1971 essay), but with a concept: hegemony. In 'Base and Superstructure in Marxist Cultural Theory' (1973) and Marxism and Literature (1977), Williams develops an original reading of hegemony, focussing it tightly around questions of lived experience and cultural production, and moreover temporalizing it via the theoretical triad of 'dominant, residual and emergent'. It is a reading of hegemony which is at once narrower and more radical than Stuart Hall's (1988) better known but broader and more orthodox (in the sense of closer to Gramsci) use in his analysis of Thatcherism in the eighties. Williams's earlier reading, I argue, is more of a re-reading, a refraction of Gramsci's political insights through the lens of, yes, a British empiricist tradition, but also a firmly totalising perspective learned from Lukacs, Goldmann and Sartre, and which found a philosophical expression conducive to Williams in the Critique. This is not to say that Gramsci himself was not a totalising thinker, but only that Williams's reading of hegemony is less indebted to versions of 'ideology' and 'culture' which stem from orthodox Marxist applications of the metaphor of base and superstructure. Indeed, the core of Williams's theory of hegemony is a heterodox Marxist critique of this, in Williams's view insufficiently totalising, paradigm.

In the final section of this chapter, in addition, I will relate Williams's re-reading of hegemony, alongside his broader writings on revolution, to another Gramscian concept: the war of position. This was Gramsci's term for the cultural struggle that socialists in the developed capitalist countries would need to wage in addition to, or even in replacement of, traditional insurrectionary struggle (or 'war of manoeuvre'). This was a) because of the greater repressive capacity of the State in the West, and b) because in the West, civil society or 'culture' was itself a field of class domination and political contestation, 'a powerful system of fortresses and earthworks' (2003, p. 238), in Gramsci's phrase, which would prevent and/or survive the felling of the State (even were that materially possible). By tracing the development of Williams's thinking about revolution from the tacitly gradualist and 'culturalist' (quasi-Gramscian) analysis of The Long Revolution (1961) to the bolder endorsements of insurrection (or the 'short revolution') in 'You're a Marxist, Aren't You?' (1976) and Politics and Letters (1979), I establish the existence of a strict dialectic, in Williams's later work, between war of position and war of manoeuvre, the revolutions long 
and short. While Williams is not generally considered a 'theorist' of revolution, I believe that the late re-conceptualization of hegemony permits us to construct a revolutionary theory from his work, a task which I look to the crucial interregnum passages in Gramsci's Prison Notebooks for assistance in outlining at the close of this chapter. As might be expected, this section is more speculative, interpretative and overtly political than the foregoing.

The significance of Williams's theorization of hegemony has not been lost on critics. In his recent essay 'The Heirs of Gramsci' (2016) Anderson, perhaps the most committed scholar of hegemony on the British left, has argued that while the reception of Gramsci in Britain began in the early sixties, 'the starting point for the major influence of his writing came with an essay by Raymond Williams' (2016, p. 2). The essay referred to is 'Base and Superstructure in Marxist Cultural Theory', from which Anderson quotes in the following discussion:

[Williams] at once endorsed and developed Gramsci's conception of hegemony as a 'central system of practices, meanings and values saturating the consciousness of a society at a much deeper level than ordinary notions of ideology'. Emphasizing that any such hegemony always involved a complex set of structures that had to be continually 'renewed, recreated and defended', actively adjusting to and where possible incorporating alternative practices and meanings, Williams distinguished two types of oppositional culture, each traceable to a class, capable of escaping such incorporation: residual and emergent - that is, rooted in either a past or in what might prove a future. For by definition, Williams insisted, hegemony was selective: 'no mode of production, and therefore no dominant society or order of a society, and therefore no dominant culture, in reality exhausts human practice, human energy, human intention.' (2016, p. 2)

Williams's vital and original move, according to Anderson, was to perform a partial disconnect between hegemony and ideology, conceiving of the dominant ideas of a society as being formed by a multitude of material practices, rather than simply being foisted onto them by a ruling elite. In this way, hegemony was rescued from its predominant sense as bourgeois control of culture and ideas. Anderson also notes the distinctively positive valence Williams attributes to some forms of hegemony, that is, the possibility of the existence of "counterhegemony' or emergent elements within a cultural and ideological structure. For Gramsci, of course, hegemony had a very specific meaning: the consensual elements of class rule. While Gramsci does relate the idea of hegemony to the idea of a 'dominant culture', there is never any suggestion that such 'dominance' is anything other than that of a class. The degree to which Williams's analysis conforms to the idea of hegemony as some form of class domination in or through culture is then the crucial question. Throughout this chapter, I 
theorize Williams's reading of hegemony as a movement away from its classical (Gramscian) formulation and towards something closer to reification, an accommodation to capitalist social relations rooted less in 'ideology' and 'consent' than in a sense of intractability attached to the experience of a persistent social reality. Let us begin, accordingly, with hegemony in its dominant valence, as the cultural dimension of class rule.

\section{Hegemonic culture as lived domination}

In his essay 'Base and Superstructure' (2005c), Williams argues that Marxism errs whenever it chooses to ground its analyses in the titular binary. 'It would be in many ways preferable', he suggests, 'if we could begin from a proposition which originally was equally central, equally authentic: namely the proposition that social being determines consciousness' $(2005 \mathrm{c}$, p. 31). Indeed, I would argue that Williams's entire oeuvre is predicated on a (usually implicit) endorsement of this shorthand of Marx's for the fundamental starting point of materialist analysis. It is there in the claim of The Long Revolution (1961) that art is a form of the communication of lived experience, where a life materially lived (social being) determines the forms of experience and response (consciousness) which arise and may be communicated in works of art. It is there in the typology of tragedy in Modern Tragedy (1966), wherein shifting experiences of tragedy (consciousness) are analysed as arising from transformations in lived social forms (social being). For Williams, the fact that 'the proposition of the determining base and the determined superstructure has been commonly held to be the key to Marxist cultural analysis' (2005c, p. 31) is evidence of a path poorly chosen: away from the basic 'social-materialist' emphasis on ideas arising from life and towards the mechanical and economistic assumptions of base and superstructure. ${ }^{82} \mathrm{We}$ should note that the basic difference between 'social being determines consciousness' and 'base and superstructure' is that the former describes a causal relation between material forces/practices and ideas, whereas the latter describes a causal relation between two levels, both of which may be said to 'contain' material practices/forces and ideas. It is thus a more complex and falsifiable assertion that there exists a relation of determination between base and superstructure, since the assertion is that a number of spheres of social life are determined by a single privileged sphere (as opposed to the grander but less controversial notion that the

\footnotetext{
${ }^{82}$ It is worth noting that a focus on the 'diffusely' materialist over the structural emphasis was also a defining feature of E. P. Thompson's Marxism; indeed, the rejection of base and superstructure in favour of local materialist analyses which are regarded as more 'historical' than those based on models of structural determination is the core theoretical similarity between Thompson and Williams.
} 
sum of all ideas results from the sum of all material practices). The determining sphere is normally conceived as what Gramsci called ‘the world of production’ (2003, p. 12).

In 'Base and Superstructure', Williams proposes a revaluation of the common definitions of 'base' and 'superstructure' and their supposedly determinative relation:

We have to revalue 'determination' towards the setting of limits and the exerting of pressure, and away from predicted, prefigured and controlled content. We have to revalue 'superstructure' towards a related range of cultural practices, and away from reflected, reproduced, or specifically dependent content. And, crucially, we have to revalue the 'the base' from the notion of a fixed economic or technological abstraction, and towards the specific activities of men in real social and economic relationships, containing fundamental contradictions and variations and therefore always in a state of dynamic process. (2005c, p. 34)

This is a straight-forward repudiation of these terms; with the superstructure rendered as 'a related range of cultural practices' and the base as 'the specific activities of men in real social and economic relationships', the distinction between the two is elided. With this blurring of the 'vertical' distinction, the 'horizontal' distinctions between different areas of social life within the base (and indeed within the superstructure) are also blurred. There are still partial and dynamic determinations (limits and pressures) but they proceed between and among a multitude of material spheres. By rejecting the traditional description of the base as comprising only the 'productive forces', Williams is guarding against the 'dismissal as superstructural, and in this sense as merely secondary, of certain vital productive social forces, which are in the broad sense, from the beginning, basic' (p. 35). Williams is neither conflating base and superstructure with 'social being determines consciousness', nor reading the superstructure as merely 'immaterial'; he is critiquing base and superstructure where it strongly deviates from Marx's more prosaic materialist binary.

Two things, both crucial to Marxist theory, risk being lost along with the traditional definitions of base and superstructure. The first is a properly Marxist theory of historical change, normally conceived of as arising from the interaction between the forces and relations of production (both 'base' phenomena), an issue which Williams does not take up at any length. The more salient issue here is that of class influence on the non-economic component of the social order. Gramsci's strategic orientation towards a war of position in the West implied that 'culture' or 'civil society' has at the very least a 'class character' (valorizing its status as a battleground of hegemony); in stronger versions, culture figures as a 
reflection and support of class rule. Traditional versions of base and superstructure theorize this by attributing to the base, with its clear and determinate class character, a strong causal influence on the superstructure/civil society/culture. 'Culturalist' positions such as Williams's seek to emphasize the status of culture not as a class-determined or class-reflective sphere, but as a contested range of meanings and practices which present the opportunity of building the foundations of socialism within spheres of society other than those which, being attributed to the base, are thought to have a privileged causal efficacy. The culturalist will then be expected to offer, in the absence of the causality affirmed by base/superstructure analysis, a replacement process to explain how a culture becomes 'classed' in the first place.

Williams acknowledges that the deconstruction of base and superstructure throws the class character of culture into doubt, and is keen to correct for it. The 'levelling' of base and superstructure militates, of course, in favour of the concept of totality, so that the question becomes: will a reorientation towards totality permit Williams to retain a Marxist analysis of how class influences culture/civil society? Williams argues that totality is 'in many ways more acceptable than the notion of base and superstructure' (2005c, p. 36), firstly because it remains 'compatible with the notion of social being determining consciousness' (p. 35), since one can theorize the material elements of the totality as determining the ideational ones, and secondly, because it avoids the 'single-sphere' reductionism of base and superstructure. But Williams is also aware that 'total' analysis does not automatically foreground class influence as immanent to capitalist society (as base and superstructure does), meaning that such influence, here figured awkwardly as 'intention', must be actively reintroduced into the theory:

If totality is simply concrete, if it is simply the recognition of a large variety of miscellaneous and contemporaneous practices, then it is essentially empty of any content that could be called Marxist. Intention, the notion of intention, restores the key question, or rather the key emphasis. For while it is true that any society is a complex whole of such practices, it is also true than any society has a specific organization, a specific structure, and that the principles of this organization and structure, can be seen as directly related to certain social intentions, intentions by which we define the society, intentions which in all our experience have been the rule of a particular class. (2005c, p. 36)

Here Williams acknowledges that the basic materialism of 'social being determines consciousness', even refracted through the concept of totality, is not sufficient for Marxist cultural analysis; class must remain a central analytic category. The somewhat idealist use of 
'intention' sits uneasily with the avowed materialism of 'social being determines consciousness'. It is a small step, however, from intention to experience (the watchword of Williams's cultural theory), so that I think we may safely read 'intentions' as primarily attesting to the presence in dominant cultural forms of the communicated experience of the ruling class.

Hegemony is the concept which allows Williams to restore to a materialist conception of totality the specifically Marxist emphasis on class domination. We know that Williams regards 'totality' as describing both the immanent relation between the material and the ideational (practical activity and consciousness) and the basic interrelatedness of different social spheres. Hegemony, Williams argues, incorporates the dimension of oppression into culture in a manner which is uniquely compatible with the 'total' emphasis:

Hegemony supposes the existence of something which is truly total, which is not merely secondary or superstructural, like the weak sense of ideology, but which is lived at such a depth, which saturates the society to such an extent, and which, as Gramsci put it, even constitutes the substance and limit of common sense for most people under its sway, that it corresponds to the reality of social experience very much more clearly than any notions derived from the formula of base and superstructure. For if ideology were merely some abstract, imposed set of notions, if our social and political and cultural ideas and assumptions and habits were really the result of specific manipulation, of a kind of overt training which might be simply ended or withdrawn, then the society would be very much easier to move than in practice it has ever been or is. (2005c, p. 37)

What Williams is critiquing here is essentially the Althusserian model of interpellation, in which subjects are constructed as agents by dominant ideological institutions (the educational and legal systems, the family etc.), as in Althusser's phrase: 'all ideology hails or interpellates concrete individuals as concrete subjects' (2008, p. 47). Williams restores to ideology a firm basis in the lives and experiences of human beings which, in keeping with 'social being determines consciousness', are the only guarantors of ideation. Dominant ideas do not arise from indoctrination or implantation, but are immanent in social life itself, a notion comparable to Gramsci's (2003) idea of hegemony as occurring spontaneously (p. 12) in the minds of workers due to their experience of capitalist society.

Now, we can agree with Williams that by dispensing with the base/superstructure metaphor we might also dispense with the 'ideological dissemination' theory of class rule. But if in doing so we sever the link between class rule and culture/consciousness entirely, we will be 
forced to question the validity of the war of position. The utility of engaging in socialist struggle on the battleground of culture depends, after all, on culture actually being a site of class power; if this is so, but the mediating process is not ideological dissemination, then what is it? Of course, while culture may be a site of class power, it is never only this; if it was, the probability of counter-hegemony would be nil. But we still need to account for the formation of the dominant element in a given culture. Why do some elements in a culture produce or contribute to the dominant, for example bourgeois, hegemony? Base and superstructure has an answer: culture reflects the class domination active in the materially determining (economic) sphere of social life. Williams's diffuse notion of hegemony cannot evade the requirement to posit causality of some kind (indeed, the idea of 'limits and pressures' gestures towards a causal framework - recall Anderson's claim of influence between Williams and E. O. Wright). The passage below gives us a sense of how Williams's is conceptualizing the 'dominant' level of a culture:

I would say first that in any society, in any particular period, there is a central system of practices, meanings and values, which we can properly call dominant and effective. This implies no presumption about its value. All I am saying is that it is central ... what I have in mind is the central, effective and dominant system of meanings and values, which are not merely abstract but which are organized and lived. This is why hegemony is not to be understood at the level of mere opinion or mere manipulation. It is a whole body of practices and expectations; our assignments of energy, our ordinary understanding of the nature of man and of his world. It is a system of meanings and values which as they are experienced as practices appear as reciprocally confirming. It thus constitutes a sense of reality for most people in the society, a sense of absolute because experienced reality beyond which it is very difficult for most members of the society to move in most areas of their lives. (2005c, p. 38)

Does 'dominant', here, do the work of 'hegemonic'? The utility of 'hegemony' vis-a-vis 'totality' was supposed to be that it restored the element of oppression; the danger in replacing this term with 'dominant' is that we end up describing not the hegemonic (classdominated) but the prevalent characteristics of a culture. There is an important advance in the acknowledgment that such characteristics emerge out of the lived experience of people in their daily lives rather than from ideological and institutional manipulation. But if they are to be read as evidence of the class-dominated nature of life under capitalism, Williams will need to explain how those 'dominant' meanings and values which reinforce class rule are actually produced. In Gramsci's analysis, hegemony results from the class character of certain basic processes which found the class character of civil society or culture, wherein hegemony is most 'deeply' produced and ingrained. One could dispense with those passages in Gramsci 
which imply direct institutional manipulation and replace them with a more Williams-esque emphasis on lived experience without altering that basic causal chain (i. production, ii. civil society/culture, iii. consciousness). But wouldn't this version of Gramscianism still be practicing the kind of reductive, base and superstructure analysis which Williams was attempting to move beyond?

The contradiction outlined above may be resolved by recognizing that class domination inheres in everyday life, that class is a direct property of life under capitalism rather than an indirect property requiring the mediation of a 'mechanism' to convert economic exploitation into specific cultural patterns. It would only be a weakness of Williams's theory that 'dominant' refers to 'prevalent' cultural elements if that culture were not already, by definition, classed under capitalism. The life of a worker, from which she draws her experience and an often contradictory set of meanings and values, is the life of a worker: exploitation is woven through the fabric of her consciousness and activity prior to the imposition of the articulate ideology of bourgeois cultural institutions. It is here that I see Williams moving away from hegemony as it has typically been understood (as 'ideological leadership' or 'cultural domination') and towards a term we have had ample cause to discuss in previous chapters: reification. Lukacs had used this to describe an epistemological distortion, rooted in the material reality of commodity production, wherein workers perceive reality as a series of fragmentary interactions rather than as a totality of integrated and classed social relations. What Lukacsian reification shares with Williams's analysis of hegemony is the idea that reified forms of consciousness are not the product of indoctrination but of the experience of workers in capitalist society. As reification naturalizes the social order, reactionary elements of consciousness appear as mental concessions to 'common sense' or an 'absolute because experienced reality'. Individuals adapt to what both is and appears as a social reality unchangeable by individual acts of resistance.

In Marxism and Literature (1977), Williams developed his theory of hegemony in ways which a) emphasized its class bias in more materialist terms, and b) interpreted it as a kind of dialectical synthesis of the terms 'culture' and 'ideology' as they had previously appeared in Marxist theory. Here is Williams's articulation of that synthesis, worth quoting at length:

'Hegemony' goes beyond 'culture', as previously defined, in its insistence on relating the 'whole social process' to specific distributions of power and influence. To say that 'men' define their whole lives is true only in abstraction. In any actual society there 
are specific inequalities in means and therefore in capacity to realize this process. In a class society these are primarily inequalities between classes. Gramsci therefore introduced the necessary recognition of domination and subordination in what has still, however, to be recognized as a whole social process.

It is in just this recognition of the wholeness of the process that the concept of 'hegemony' goes beyond 'ideology' ... Ideology, in its normal senses, is a relatively formal and articulated system of meanings, values, and beliefs, of a kind that can be abstracted as a 'world-view' or a 'class outlook' ... [Hegemony] is distinct in its refusal to equate consciousness with the articulate formal system which can be and ordinarily is abstracted as 'ideology'. It of course does not exclude the articulate and formal meanings, values and beliefs which a dominant class develops and propagates. But it does not equate these with consciousness ... Instead it sees the relations of domination and subordination, in their forms as practical consciousness, as in effect a saturation of the whole process of living ... the whole substance of lived identities and relationships, to such a depth that the pressures and limits of what can ultimately be seen as a specific economic, political and cultural system seem to most of us the pressures and limits of simple experience and common sense. (2009 [1977], pp. 108110)

Hegemony revivifies the notion of culture by restoring the focus on class oppression lost in the transition from a 'base and superstructure' analysis to one based on totality. Moreover, it 'materializes' ideology, emphasizing the origin of meaning in practical activity (lived experience), and the centrality of processes which naturalize and universalize the dominant social order (I have linked these to reification). In an interesting turn of phrase, Williams then defines hegemony as "a "culture", but a culture which has also to be seen as the lived dominance and subordination of particular classes' (p. 110). Williams will clarify that while this characterisation need not make 'culture' coterminous with 'oppression', it nevertheless militates against prior notions of culture, including Williams's own, which tended to evade its political critique by foregrounding the collective nature of the underlying experiences. Here there is a clear recognition that the 'social being' underlying cultural experience under capitalism is a product of exploitative disparities in access to the (material) means of life and self-determination. Culture is still 'ordinary', but this is because oppression is an ordinary fact of class society.

Is Williams's not a superstructural argument after all? Isn't this just a roundabout way of saying, albeit with greater attention to lived experience, that economic exploitation produces a culture which reflects/buttresses that exploitation? Here we should note that while the concept of hegemony can survive without superstructural analysis (i.e. the assertion of a direct causal relation between an exploitative economic base and cultural forms which 
support and augment that oppression), it is not its antithesis, and may in many cases incorporate it. Gramsci's work retains a strong sense of superstructural causation, in which much of the hegemonic culture is seen as proceeding from and supporting the exploitative economic base. That there are more 'spontaneous' or directly experiential elements within hegemony (art, for example) does not necessitate throwing out structural causation entirely. Eagleton, in his 'Base and Superstructure in Raymond Williams' (2007a), offers a version of this critique. He argues that Williams is wrong to replace the superstructure with hegemony, and that the economic base is foundational in constructing those elements of culture that support class power. Eagleton acknowledges Williams's point that we cannot regard whole regions of social life (art, literature etc.) as merely superstructural and therefore politically compromised, but he defends superstructural analysis on the grounds that it may still describe those elements within a culture which are collusive:

An institution or practice is 'superstructural' when, and only when, it acts in some way as a support to the exploitative or oppressive nature of social relations ...

'Superstructural', in brief, is a relational term: it identifies those particular aspects of a social practice or institution which act in particular conditions as supports of exploitation and oppression, invites us to contextualize that practice or institution in a specific way ... [Williams] is right that cultural activity is not superstructural tout court ... But as soon as you come, for example, to read a literary text for symptoms of its collusion in class power, as Williams has also many times perceptively done, then you are treating it 'superstructurally.' (2007a, p. 174)

While one welcomes Eagleton's refusal to dismiss culture as merely a reflection of the base, it remains unclear why 'superstructural' should be preferable to 'hegemonic' as a description of a given cultural product unless one $i$ s asserting a causal link between it and the 'economic base'. Eagleton appears to be using 'superstructural' in much the same way as Williams uses 'hegemonic' (not as a descriptor of whole compromised social spheres, but of those specific cultural forms and products which are in fact colluding with dominant meanings and values), with the result that Eagleton's preference for 'superstructural' appears more as an aesthetic preference than a sound analytic discrimination. It seems reasonable to distinguish those cultural features which are really superstructural in the traditional sense (proceeding from the economic base, e.g. property rights) and those which, while not being superstructural per se, nevertheless ‘build' hegemony (e.g. specific artistic works). But Eagleton's use of superstructural does not accomplish this; it simply describes everything which is collusive with class power beyond immediate economic relations as 'superstructural' rather than as hegemonic. While Eagleton's critique is insufficient, we should also recognize that 
Williams's all-encompassing use of hegemony may also be inadequate for distinguishing between properly superstructural and otherwise collusive cultural elements.

My own position is that the 'superstructural' ought to be considered a partially overlapping sub-set of the 'hegemonic'. Neither Williams nor Eagleton's analyses do this explicitly, but I think Williams's work implies such a procedure. Recall that the analytic value of 'hegemony' is that it names domination within a class system in a wider sense than pure economic exploitation. The value of 'superstructure' is that it describes a specific causal relation between elements of the economic system and elements of culture. Neither term does the work of both. There are clearly elements within 'civil society' which do proceed from the economic base, but are not collusive with class power and thus hegemony (e.g. trade unions), just as there are elements which do not proceed directly from the economic base, but do contribute to the dominant system of meanings and values (e.g. conservative talk radio). Williams's analysis reminds us that the class domination which hegemony names is buttressed at a far greater number of points than are captured by traditionally superstructural analysis. An enormous range of material practices with diffuse causal origins produce ideations which contribute to the dominant system of meanings and values i.e. the hegemony of a class society; superstructural effects contribute to this, but hegemony is not exhausted by them. Williams never asserts that economic exploitation and its attendant institutional, repressive and legal requirements do not produce profound cultural effects, or comprise a significant part of what is called 'class rule'. ${ }^{83}$ In Williams's work, the material and social requirements of economic exploitation conspire with lived experience and its attendant (often reified) meanings and values to produce a dominant culture (hegemony) that is 'the lived domination and subordination of particular classes'.

I am aware that I am taking certain liberties. For one, Williams downplays the idea of a superstructure to a greater degree than in my interpretation of his theory above, at times effectively dissolving it into hegemony. However, it is precisely the virtue of hegemony as Williams uses it that it does not erase what are normally called superstructural effects, but incorporates them into a wider definition of class power. Another possible objection to my assessment here is that Williams does not himself use the word 'reification' to describe the

\footnotetext{
${ }^{83}$ Indeed, quite the opposite. As Williams states in 'You're a Marxist Aren't You?' (1989r): 'the essential dominance of a particular class in society is maintained not only, although if necessary, by power, and not only, although always, by property. It is maintained also and inevitably by a lived culture' (p. 74).
} 
process whereby, via the lived experience of material practices, a historically contingent social order is made to seem natural and unchangeable. The reason that Williams does not reach for the term in this context is, I think, because he imbibed the term from Lukacs, who used it to refer not to naturalization per se, but to a fragmentary and atomized perception of social relations which was the mortal enemy of the perspective of totality (naturalization, of course, was one effect of this). To explain the omission, then, we need only recall that, for Williams, hegemony is precisely the concept that takes us beyond totality by explicitly reintroducing the element of class oppression. Lukacsian reification was combatable by the perspective of totality; hegemony is a more diffuse enemy, present in a far greater number of processes than the commodity fetishism upon which (Lukacsian) reification was based. Such a pervasive, lived edifice of 'common sense', that sense of 'absolute because experienced reality', will have to be combated by something which incorporates but supersedes the perspective of totality as Williams understood it from Lukacs and Goldmann.

Let us now recall that the whole purpose of Gramsci's emphasis on hegemony, produced within 'civil society', was to explain the stubbornness of bourgeois rule in the absence of state violence in the capitalist West. The 'mechanism' Gramsci offered was consent; through a combination of confidence (leadership of the economic system) and ideological manipulation (via schools, churches etc), citizens were successfully enjoined to consent to living under capitalist rule. Williams's analysis of working-class passivity, which I have linked to a version of reification, problematizes the notion that consent secures class rule in the West. Indeed, reification does not index consent, but rather the degree to which human beings view their situation as something which is changeable at all (Brecht, whose plays dramatized the contingency and human-centredness of history, went further than either Lukacs or Sartre in combating reification). By emphasizing hegemony as 'a sense of absolute because experienced reality', Williams draws us away from both a) the dominant culture as a system of ideological manipulation (Althusser), and b) the idea that workers have 'confidence' in the ability of elites to administer society (Gramsci). At the same time, Williams's identification of the 'dominant' culture as the 'lived domination and subordination of particular classes' shows that he views the material day-to-day of capitalist existence as producing ideations which are deeply compatible with bourgeois rule.

In the following section, we shall examine the relation between Williams's triumvirate of 'dominant, residual and emergent' strains within a culture and the prospects for a Gramscian 
or semi-Gramscian war of position. Crucial to this is establishing the conditions for the emergence of a socialist counter-hegemony, and the temporal character of such a shift. Gramsci's crisis theory, the central passages on 'interregnum' in the Prison Notebooks, will be crucial here. We shall find that Williams's rough equivalent of a war of position, his 'long revolution', ought not to be read as a sufficient praxis for the achievement of socialism, but rather as designating a preparatory phase of ideological work, to eventually be superseded by revolution proper or a war of manoeuvre. Gramsci's writings on interregnum, as we shall see, anticipate something very like a 'cultural materialism', a new common sense rooted in the materialist self-understanding of historically situated and classed human beings. A link will then be drawn between Williams's radical re-envisioning of Gramsci's hegemony and the crucial epistemological lessons he drew from Sartre's elaboration of dialectical materialism, in which human beings both arise out of and give rise to history.

\section{The long war of position}

Was Williams a revolutionary socialist? Our answer may depend on how seriously we take Gramsci's lesson that there are different kinds of revolution, and that different kinds of social transformation may be required in different kinds of society. I think Barnett (foreword to Williams, 2011b [1961]) is correct when he states, citing Modern Tragedy as evidence, that Williams 'proposed a moral reckoning, neither refusing revolution nor denying what it means' (2013, xxi), and moreover that Eagleton's reproach to Williams (in 'Criticism and Politics') that he failed to 'embrace insurrectionary organisation' (xxii) was not in the end reasonable. As we shall see, Williams endorsed revolutionary violence where necessary, and was determined to conceptualize revolution in its fullest possible terms, as the working through of social disorder, with full recognition of the scale of human suffering involved. A different point, however, is suggested by Barnett's observation that the 'customary use of the word "revolution" is different from that in Raymond Williams's [TLR]' (vii). With the term 'long revolution', Barnett argues, 'Williams is theorizing a different epochal process, not saying "Hey, this revolution is taking a long time" - as if the revolution referred to is selfevident and he telling us about its duration' (vii). This is correct; Williams's 'long revolution', also described as the 'cultural revolution', is a different species of social phenomena to what is normally described as revolution within the Marxist tradition. It is of the same genus of epochal change as the democratic and the industrial revolutions, and it shares with those transformations a youthful and ongoing character: 
It is evident that the democratic revolution is still at a very early stage $\ldots$ the industrial revolution, in its broad sense, is also at a comparatively early stage ... We speak of a cultural revolution ... the aspiration to extend the active process of learning, with the skills of literacy and other advanced communication, to all people rather than to limited groups ... Of course, this revolution is at a very early stage. (2011b [1961], p. 11)

Clearly, even nearly sixty years after Williams wrote $T L R$, both the democratic and the industrial revolutions are ongoing; the transformations wrought by their immediate 'occasions' did not produce self-contained revolutionary moments, but rather ignited parallel processes of radical social and economic change that continue to unfold. In this sense, the cultural revolution which Williams names as 'long' is only one of three long revolutions, or three aspects of a single extended transformation. This observation raises a question with both historical and strategic weight: towards what end, if any, does the variegated process which Williams identified wind? For it remains the case that all three revolutions arose out of, and in their continuing development have sustained and powered, the capitalist mode of production. If the long revolution excludes, as it seems to in $T L R$, a traditional revolutionary break with the old order, should it be regarded as a gradualist strategy (where socialism, an entirely new society, is at least the stated end goal), or as not-even-gradualist, that is to say, a description of the ongoing development of capitalism in a progressively more humane direction? Neither description, it seems to me, is adequate.

Williams wrote The Long Revolution prior to his rapprochement with Marxism in the late sixties and seventies. The trajectory of his political thought in this period evinces a shift away from the 'gradualist' or parliamentary strategy and towards recognition of the necessity of violent insurrection in the long run, as part of an expansively defined revolutionary transformation. While Williams was never entirely opposed to insurrection, he was until the mid to late-sixties unsure of its salience for the socialist movement in the West where, as Gramsci had described, the preconditions for insurrection were lacking. By the late seventies, Williams had arrived at a characteristically synthetic position. In conversation with Perry Anderson in Politics and Letters (1979), Williams explicitly repudiated the gradualist option and asserted the necessity of a 'short revolution' (a Gramscian war of maneuver), in which State power is dismantled by force. The 'long revolution' (a Gramscian war of position) remains vital, however, with the two forms of revolutionary activity now conceived as 
mutually constitutive. In the following passage Williams (1979) clarifies his late position and its development:

An East European said to me after reading The Long Revolution: 'We've had our short revolution, now we begin our long revolution.' When I wrote [TLR] I was mainly conscious of the immense length of the full social transformation, which has usually been under-played, yet which should be intrinsic to all strategic socialist thinking. I have no doubt now that the short revolution, to use that phrase, has also to occur. I wouldn't at all dissent from the traditional notions of the violent capture of state power, but I would put this revolution in a more specific way: it is accomplished when the central political organs of capitalist society lose their power of predominant social reproduction - which does not have to mean that some reproduction will not continue afterwards. So to make the theoretical position clear - I now believe, though I have not always believed, that the condition for the success of the long revolution in any real terms is decisively a short revolution, which I would define not so much in terms of duration as the loss by the state of its capacity for predominant reproduction of the existing social relations ... Talking about the run-up to that situation is not a form of gradualism ...I think the learning of the skills of popular organisation and control, over a wide range, would make the prospect of preventing the effective reproduction of the existing social relations a much more realistic possibility in Western capitalist societies. (2015 [1979], pp. 421-422)

The anecdote about the East European, with a short revolution preceding a long one, is instructive; the cart appears to have been put before the horse. Generally, Williams's analysis suggests, the long revolution will precede and lay the foundations for the short. In return, the short revolution facilitates the fruition of the long. The short revolution will be an act of violence against the state, but it will only succeed if it results, in concert with the long, in the destruction of the state's capacity to reproduce the existing social relations. Focusing on the 'run-up' to that ultimate deconstruction of state power, 'learning the skills of popular organisation and control' (ingraining participatory democracy and self-determination into all spheres of life), is decidedly not gradualism; it is the process whereby a society becomes capable of the full range of revolutionary actions. But this preparatory work will also be vital for what comes after the short revolution, in the period of socialist construction, and also for the prevention of counter-revolution: 'One crucial pattern since the classical theory [of revolution] was formulated, after all, has been that form of crisis of the ordinary capitalist state which leads not to the emergence of a new popular power, but to the hardening of the state itself into an even more repressive form - into fascism. So I am always uneasy about talk of the short revolution when the problems of the run-up to it have not really been appreciated' (p. 422). Following this, the East European anecdote appears less incongruous. The long revolution primarily names the period of preparation, but it also evokes a longer and 
more indeterminate process which extends through and beyond the destruction of the capitalist state.

At stake in Williams's political development is the nature of social breakdown and renewal, hegemonic death and rebirth. That Williams eventually comes to believe that a violent confrontation with the state will be necessary, that the long and the short revolutions, taken together, are the revolution, is not the critical point. What is more important from the perspective of Williams's reception of Gramsci is the character of revolutionary change itself. The turning point for the incorporation of war of maneuver elements into Williams's work was 1966 with the failures of the Labour government; this was also the period of Modern Tragedy, a socio-literary meditation on the necessity of negativity in massive social change and, accordingly, a profound critique of gradualism. There, Williams argued that while most revolutions are violent, this is not their fundamental character. The essential process is one of total transformation:

We need not identify revolution with violence or with a sudden capture of power. Even where such events occur, the essential transformation is indeed a long revolution. But the absolute test, by which revolution can be distinguished, is the change in the form of activity of a society, in its deepest structure of relationships and feelings. (1966, p. 76)

This is written prior to Williams's most significant period of contact and engagement with Western Marxism, including Gramsci, but the conditions of British capitalism and socialist struggle are such that he nevertheless channels Gramscian themes. Even violent conflagrations, here, have the character of a long revolution, in that they represent the culmination of a long process of transformation of the whole social order. The result is a change in the form of a society, so that afterwards, one may say that it is a different society, rather than that the old society has been altered. This change in the form of society is, says Williams, 'the inevitable working through of a deep and tragic disorder' (p. 75). It is tragic in itself, in that it creates its own forms of suffering (not least that associated with violence), but also in that it originates in the suffering produced by the experience of social disorder: 'It is born in an experience of evil made the more intolerable by the conviction that it is not inevitable, but is the result of particular actions and choices' (p. 77). Revolution occurs, then, when there exists the conviction that endemic social disorders are the product of and may be remedied by human actions. Recalling the previous section, we should add that this humanist conviction, insofar as it is true, is also a form of knowledge, an epistemological achievement 
that marks the defeat of reification or naturalization. The dissolution of reification is thus the first step in pursuing revolutionary change; its achievement would indicate that the prevailing hegemony, the prevailing sense of 'absolute because experienced reality', is breaking down.

As of $M T$, Williams had not been fully convinced of the necessity of the short revolution, but he knew that that neither social-democratic gradualism nor Stalinism were equipped to combat reification. Each had only one half of the revolutionary map. Gradualism recognized the agential social power of human beings, but not the necessity of total transformation and the painful, subjective involvement working through social disorder would entail: '[Social democrats] have identified war and revolution as the tragic dangers, when the real tragic danger, underlying war and revolution, is a disorder which we continually re-enact ... The only consciousness that seems adequate in our world is then an exposure to the actual disorder ... a participation in the disorder, as a way of ending it' (1966, pp. 78-81). Stalinism, inverting this, proposed a revolutionary process enacted through rather than by human beings: 'the revolutionary purpose can become itself abstracted and can be set as an idea above real men ... There is the related imposition of an idea of the revolution on the real men and women in whose name it is being made' (p. 82). In this authoritarian schema, revolution is understood to entail suffering, but not tragic suffering; the suffering produced by a revolution which absents full human involvement is more akin to the reified liberal conception of urban poverty and alienation as the 'cost' of industrial-civilizational progress. Both the gradualist expulsion of revolutionary tragedy and the Stalinist expulsion of human beings from it vastly underestimate of the scale of the problem. The tragic nature of any revolutionary assault on social disorder cannot be reckoned with by avoidance (gradualism) or endorsement (Stalinism), but only by 'its experience, its comprehension and its resolution' (p. 83). A properly revolutionary involvement thus proceeds through 'lived comprehension' or 'practical consciousness'; the disorder inhering in the social edifice is comprehended objectively, as really existing (against the gradualist view), but because that comprehension is 'lived' i.e. experienced subjectively, it cannot be mistaken for a purely objective process i.e. one beyond substantive human involvement, as in Stalinism. This is the perspective of totality, and we saw in Chapter Two how much Williams would later appreciate Sartre's systemization of such 'total' cognition in his Critique.

In the mid-seventies, Williams made a similar critique of extant socialist strategies in terms more familiar to the Marxist tradition. In 'You're a Marxist Aren't You?' (1975) he recounts 
how the New Left, while seeing Marxist-Leninism as having arrived at 'an effective dead end', saw also that 'the apparently alternative tradition - that of Fabianism, the British Labour Party, the modern social democratic parties - indeed the whole tradition summed up as the inevitability of gradualism, was equally at an end' (1989r, p. 68). Under the rubric of 'modernization', gradualism assumed 'that there was not an enemy, there was only something out of date' (p. 69). It had become a means of incorporating the forces of socialism and of preserving, updating and strengthening, capitalism. Under a liberal rubric of 'freedom', the core socialist position that 'the basic ownership of the means of production, distribution and exchange determined the character of the society or at least set limits to the possibilities of such relationships' (p. 69) was abandoned, the result being, in Williams's view, that it 'abandoned the possibility of understanding or changing the modern world' (p. 69). Against this, Williams reaffirms his own allegiance to fundamental Marxist principles:

Now as I think through the basic position of historical materialism, the basic definition of capitalist society and its evolution, and then the need to supersede it, to go beyond capitalist society, so that a socialist society, as apart from isolated measures of a socialist tendency, demands the destruction of capitalist society, as I think through these three propositions and try to define myself in relation to them, I have no real hesitation. These are all positions from which I now see the world and in terms of which I try to order my life and activity. (1989r [1975], p. 72)

Destruction, Williams acknowledges, will usually mean violent defeat, and he locates his refusal to deny this in his experience of the war: 'By 1944 I, who had called myself a pacifist in 1938, was in Normandy ... since that time I have never been able to say that the use of military power to defend a revolution is something that I am against' (pp. 72-73). He goes further, connecting violent revolutionary struggles the world over to a speculative British revolutionary future: 'When I look at the history of the Chinese, the Cuban and the Vietnamese revolutions, I feel a basic solidarity not merely with their aims but with their methods and with the ways in which they came to power. If I found myself in Britain in any comparable social and political situation, I know where my loyalties would lie' (p. 73). Such unequivocal statements as these on the necessity of revolutionary violence suggest that Eagleton's assessment of Williams's 'reticent and ambiguous attitude towards insurrectionary organisation' (p. 10) was not reflective of Williams's position in the seventies. This may be a case of ungenerously importing a reading of Williams's earlier work into analysis of the later. 
I belabor the point about revolutionary violence to underscore Williams's opposition to a) the notion that the two strategies of war of maneuver and war of position were mutually exclusive, b) the idea that the war of maneuver is a strategy irrecoverably linked to a defunct Marxism, and c) the view that the New Left, with its 'culturalist' emphasis, was an antiinsurrectionary movement. Like Gramsci, the New Left was seeking to describe how developed capitalism had made violent insurrection an insufficient, not an inappropriate, vehicle for social transformation. Indeed, as Williams explains in 'You're a Marxist', Gramsci's insights were central:

In seeking to define this, it was possible to look again at certain important parts of the Marxist tradition, notably the work of Gramsci with his emphasis on hegemony. We could then say that the essential dominance of a particular class in society is maintained not only, although if necessary, by power, and not only, although always, by property. It is maintained also and inevitably by a lived culture: that saturation of habit, of experience, of outlook, from a very early age and continually renewed at so many stages of life, under definite pressures and within definite limits, so that what people come to think and feel is in large measure a reproduction of the deeply based social order which they may even in some respects think they oppose and indeed actually oppose. And if this is so, then again the tradition of Stalinism and the tradition of Fabianism are equally irrelevant. (1989r, pp. 74-75)

This returns us to the centrality of Gramsci in establishing some of the basic directions of Williams work. For Williams and for the New Left more generally, the Gramscian emphasis on cultural hegemony rendered both major socialist options defunct. Stalinism took a "war of maneuver' approach to hegemony, attempting to change the dominant culture through 'redirection and manipulation' (p. 75) and underestimating 'the real process of human change that has to occur' (p. 75). Fabianism, however, was not merely the obverse of Stalinism when it came to hegemony; ${ }^{84}$ it was rather, Williams argues, the inheritor of utilitarianism within the labour movement and '[did] not even seem aware of the problem [of hegemony] at all' ( $p$. 75). Fabianism, we might say, was a war of position without the war, a non-insurrectionary programme which failed even to recognise an alternative arena of socialist struggle. It fell to the New Left to recognize that revolution meant a war on two fronts or, as Williams would put it in $P L$, a long revolution on the terrain of culture, meaning and experience, and a short revolution against the State's capacity to reproduce the exploitative social relations of capitalism.

\footnotetext{
${ }^{84}$ The idea of a 'pure' war of position is perhaps better conveyed by the usually derogatory term 'culturalist', a caricature of the New Left position implying an insufficient commitment to revolution.
} 
Williams, as Anderson later recognized, took the cultural struggle more seriously than his contemporaries, nuancing Gramsci's insights to develop a distinctive theory of hegemony. The first pillar of that theory was the de-ideologization of the received notion of hegemony as indoctrination or manipulation, replacing this with the deep, lived saturation of a dominant social order into the day-to-day expectations and conceptual frames of individuals (a process I have argued is closer to reification). The second pillar is Williams's tri-partite structuration of hegemony via the concepts residual, dominant and emergent. I discussed Williams's analysis of the dominant mode of hegemony in the previous section; I turn now to the residual and emergent modes.

Firstly, the dominant mode really is dominant; residual and emergent elements exist within it, but in differing degrees of incorporation. In 'Heirs of Gramsci', Anderson argues that 'Williams distinguished two types of oppositional culture, each traceable to a class, capable of escaping such incorporation: residual and emergent - that is, rooted in either a past or in what might prove a future' $(2016$, p. 2). This may be overstating the case; the class link to particular elements is often tacit, with the different modes explicitly paralleled not with classes but with different 'social formations' or 'ways of life' (cultures). There are also differences in the ways these links operate across the three modes. Williams initially defines the two oppositional modes as follows:

By 'residual' I mean that some experiences, meanings and values, which cannot be verified or cannot be expressed in terms of a dominant culture, are nevertheless lived and practiced on the basis of the residue - cultural as well as social - of some previous social formation ... By 'emergent' I mean, first, that new meanings and values, new practices, new significances and experiences, are continually being created. (2005c, p. 40-41)

Williams fleshes out what 'residual' might mean in practice by citing 'religious values' ( $\mathrm{p}$. 40 ) and, 'in a culture like Britain ... certain notions derived from a rural past' (p. 40). It is not reading too much into Williams's analysis to cipher this as a feudal social order, but again, the structural parallelism is between that whole way of life and its surviving elements, not the latter and the delimited values or articulate ideology of a feudal aristocracy. 
Two issues now suggest themselves for clarification. Firstly, if each mode is not quite 'traceable' to a class, what is each mode traceable to? Here, it will be useful to recall our analysis of the dominant mode. I read Williams's analysis as suggesting that the dominant mode was comprised of, a) elements issuing more or less directly from the imposed values of a ruling class and the structural requirements of the mode of production (ideological and superstructural elements), and b) from the experiential texture of the given, dominant way of life, perceived as an unchangeable reality or common sense (reified or otherwise hegemonic elements). In the case of residual elements, however, the balance of superstructural and reified elements must be rather different. Assuming that, in the British context, residual refers to a feudal/rural way of life, we must immediately recognize that this way of life no longer exists, and that a landed aristocracy is no longer the dominant class. The residual elements within contemporary, bourgeois hegemony, then, cannot be superstructural, since there is no ruling aristocracy to impose its values, and no feudal mode of production requiring a specific institutional framework. In a striking confirmation of Williams's insistence that superstructural analysis is never sufficient, we can say that residual elements must be entirely non-superstructural; they exist entirely within lived social experience, in traditional practices transmitting the values of a previous social formation, the historical elements of a particular cultural imaginary, forward in time. Of course, residual elements from monarchic pageantry to Imperial nostalgia are routinely used as supports of class rule at home and abroad (they are, in other words, 'incorporated'). It is precisely the value of 'hegemony' that it permits us to recognise the role of such experiential elements in maintaining systems of oppression.

The situation is more complicated in the case of emergent elements. Here, Williams draws both on Gramsci and on the wider Marxist tradition:

We have indeed one source [of emergent elements] to hand from the central body of Marxist theory. We have the formation of a new class, the coming to consciousness of a new class. This remains, without doubt, quite centrally important. Of course, in itself, this process of formation complicates any simple model of base and superstructure. It also complicates some of the ordinary versions of hegemony, although it was Gramsci's whole purpose to see and to create by organisation that hegemony of a proletarian kind which would be capable of challenging the bourgeois hegemony. We have then one central source of new practice, in the emergence of a new class. (2005c, p. 42)

The notion of a rising class 'complicates' the received base and superstructure model because that model addresses itself to the dominant mode, to the requirements of an existing mode of 
production and its ruling class. This is a good example of why social being/consciousness is better than base and superstructure: it permits the inclusion into the complex of meanings, values and practices which make up a culture those elements which proceed from oppressed or subaltern groups, whose materiality is itself a sector of social being. Insofar as certain emergent elements express the interests and values of the rising class, they are in what we might call the 'subaltern superstructure'. But there are also more diffuse emergent elements which 'can be different in quality from the developing and articulate interests of a rising class. They can include, for example, alternative perceptions of others, in immediate personal relationships, or new perceptions of material and media, in art and science, and within certain limits these new perceptions can be practiced' (p. 44). Here we have an emergent texture of lived experience which sits outside what is sanctioned and understood by the dominant order (and beyond what is recognizable to the residual). Williams clearly distinguishes, then, between those emergent elements which proceed from class consciousness or interest, and those which issue from a more diffuse lived experience. 'At times they can be very close', Williams notes, 'and on the relations between them much in political practice depends. But culturally and as a matter of theory the two can be seen as distinct' (p. 44).

Before proceeding, let us emphasize again that the two 'factors' of hegemony, class interest, directly ('superstructurally') expressed and lived, 'textural' experience (practical consciousness or reification) operate differently in each mode. For the dominant mode, superstructural effects are important because they proceed from a presently existing mode of production and ruling class interest (of course, as we saw in the previous section, the experiential or reified element is also vital for a functional hegemony). For the residual mode, superstructural effects are next to non-existent, since the mode of production and dominant class of the society to which it corresponds no longer exist. The residual mode, therefore, is entirely reliant on experiential elements linked to a cultural memory. For the emergent mode, things are different. Unlike with the residual elements, the 'rising class' to which one part of the emergent may be related really exists; that class, however, does not preside over a mode of production suitable to its interests. This puts the emergent mode, insofar as it is linked to a 'rising class', in a liminal position. It produces cultural elements which cannot be easily incorporated into the dominant mode, and which the residual mode does not recognize, but the way of life to which those elements may be 'referred' has never existed, does not now exist, and has no guarantee of ever existing. 
In Marxism and Literature (1977), Williams nuances the emergent mode, distinguishing between elements which are merely new and those which may be said to presage the eventual construction of a persistent counter-hegemony, a change in the form of society. 'It is exceptionally difficult', argues Williams, 'to distinguish between those which are really elements of some new phase of the dominant culture ... and those which are substantially alternative or oppositional to it: emergent in the strict sense rather than merely novel' (2009, p. 123). Indeed, the word 'emergent' connotes not novelty but the early development of something more fully formed, something intimated by culture which has yet to emerge 'in full' historically. Williams emphasises that not everything which is emergent proceeds from the interests and influence of the rising class: 'there is always other social being and consciousness which is neglected and excluded ... In practice these are different in quality from the developing and articulated interests of a rising class' (p. 126). Nevertheless, we know that Williams accepts the basic propositions of historical materialism, including 'the basic definition of capitalist society and its evolution' (1989r, p. 74), the need to supersede it and construct socialism and the centrality in this of 'the fundamental resistance to capitalist state power' (p. 74) and the agency of 'the industrial working class' (p. 74). When Williams speaks of the oppositional emergent, then (as opposed to the novel or otherwise excluded/unrecognized), he is describing the stirrings of an oppositional culture, a culture concomitant with the 'total transformation' of society, a new mode of production and a new class structure. In Marxism and Literature, Williams signals the gestational nature of this proto-socialist emergent by comparing it to an utterance or sign that has not yet reached full articulation:

What matters, finally, in understanding emergent culture, as distinct from both the dominant and the residual, is that it is never only a matter of immediate practice; indeed it depends crucially on finding new forms or adaptations of form. Again and again what we have to observe is in effect a pre-emergence, active and pressing but not yet fully articulated, rather than the evident emergence which could be more confidently named. (2009 [1977], p. 126)

The idea of 'pre-emergence' is consistent with the notion of a war of position as preparatory, a phase in which the seeds are planted of something which will come to fruition only with the war of manoeuvre or short revolution (as well as ensuring the sustainability of these shorter actions). But what is it, exactly, that is emerging? The linguistic metaphor evokes Williams's long-standing emphasis, from The Long Revolution onward, that culture is a form of the communication of lived experience. The (oppositional) emergent sector of a culture, then, is a 
form of the communication of the lived experience of the rising class. 'Full articulation' of that experience would mean articulation without the influence and distortion of the dominant sector of the culture, both in its form as the expressed interest and ideology of the dominant class, and as a reified set of assumptions and expectations within the rising class itself.

Even if the above account of pre-emergence is correct, it remains to establish the conditions under which full emergence could occur. This would essentially be the passing from one dominant hegemony to another and, on the evidence of both Williams and Gramsci's analyses, this would have two major preconditions. First, the attainment by the emergent culture of a certain degree of sufficiency, that is, of successful communication. The emerging culture would need to account for the experience of the rising class to the point where it could provide an image, both descriptive and affective, of a new social order. Second, the dominant hegemony would need to fail, both practically and ideologically, to offer values and meanings to a rising class which would then reject the central pillars of the dominant culture; historically, this has perhaps its only occasion during periods of economic crisis or war. Even if the second condition has been met, however, the emergent culture will fail to take hold if the first condition has not. The successful production of an emergent culture, synonymous with successful communication of the experience of the rising class, is what prepares that class to seize the opportunity afforded by the failure of the dominant hegemony.

Let us pause here to consider some interactions between Sartrean and Gramscian ideas as they relate to Williams's late Marxism. Sartre had warned against 'abstract universality', wherein the meanings and values of the dominant class are foisted onto the oppressed. Williams's nationalist turn in the early seventies was precipitated by the recognition that pluralism, by acknowledging radical differences in experience ('concrete particularism'), was the only cultural programme adequate to taking Sartre's warning seriously. What Williams later came to realize, however, was that acknowledging experiential plurality was not the same thing as the perspective of totality. A total or 'realist' perspective also required that we look beyond experience, using formal and abstract modes of cognition to perceive the objective determinants of the social edifice. Williams recognized the synthesis of these epistemological strategies in Sartre's 'dialectical reason', in which objective knowledge is incorporated into experience (interiority), augmenting experience and making it adequate to historical reality. 
The Sartrean terminology maps neatly onto Williams's temporal theory of hegemony. What Sartre calls 'abstract universality' closely resembles Williams's 'dominant' mode as an overlaid set of meanings and values which fails to address the experience of the rising class. 'Concrete particularism' is akin to the emergent as that portion of culture which does express the experience of the rising class, but is not yet dominant. What I described in Chapter Two as 'abstract particularism', the appeal to a no longer existing social formation to provide meaning for the present, is not dissimilar to the residual mode. In 'The Burgos Trials', Sartre presented the fourth term, 'concrete universality', as an emergent property of the recognition of every particularism; rather than expressing something unique in itself, concrete universality was a universality of particularisms, a universal emancipation predicated on the recognition of every specific injustice. But hegemony demands that we go further. Concrete particularism is already manifest in what Williams calls the 'pre-emergent' i.e. the emergent as it exists within the current hegemony. Full emergence, on the other hand, cannot be either separation, in which emergent meanings and experiences exist as alternatives to the dominant hegemony, nor incorporation which, in the manner of Labourist/Fabian ideology, seeks to alter the dominant mode so that it can include a portion of the emergent meanings (social democracy). The prospect of full emergence enjoins us to build the oppositional elements of the emergent to the point of replacement. The production of a culture which is the full articulation of the experience of the rising class demands the replacement of one hegemony with another.

Clearly, hegemonic replacement is a goal beyond the resources of either the long or the short revolutions in isolation. The 'moment' of the short revolution, moreover, normally figured as the moment of insurrection or war of manoeuvre, is not autonomous of the long revolution; indeed, my argument has been that Williams's theory of hegemony necessitates the active presence of both revolutions in the crucial phase of transition from one hegemony to another. Gramsci provides us with a crucial theorization of what such a transition may entail in his passages on 'interregnum' in The Prison Notebooks. He begins by imagining a scenario in which, while the capitalist state persists, bourgeois domination at the level of culture and experience (hegemony) has broken down spontaneously due to a severe crisis:

If the ruling class has lost its consensus, i.e. is no longer 'leading' but only 'dominant', exercising coercive force only, this means precisely that the great masses have become detached from their traditional ideologies, and no longer believe what they used to believe previously, etc. The crisis consists precisely in the fact that the 
old is dying and the new cannot be born; in this interregnum a great variety of morbid symptoms appear. (2003, pp. 275-276)

Gramsci is describing what I suggested was the second condition of full emergence: the severe failure of the dominant culture to offer a compelling set of meanings and values to the rising class. We can assume that conditions of severe economic crisis or war prevail. The capitalist class is now using force only to exercise control; it has lost hegemony but not power. What immediately ceases to function here is reification, that sense of 'absolute because experienced reality' that Williams identified as the root of the dominant hegemony. The social order has in fact ceased to operate, proving at once its contingent nature. Thus, while the old is dying, 'the new cannot be born'; we are in an interregnum, a space between hegemonies, the great danger of which is what Gramsci calls 'Caesarism' or authoritarian military rule.

Getting to a new, socialist hegemony will require not just the failure of the old but also what I have called, developing Williams's theory, the full emergence of the rising class's culture. But the same problem which attends the 'pre-emergent' under normal conditions also attends the rising class in the period of crisis: its emergent culture does not correspond to a readymade social formation. Moreover, the ruling class still holds the levers of the state. Consider, in this light, Gramsci's description of the deadlock the interregnum represents:

The problem is the following: can a rift between popular masses and ruling ideologies as serious as that which emerged after the war be "cured" by the simple exercise of force, preventing the new ideologies from imposing themselves? Will the interregnum, the crisis whose historically normal solution is blocked in this way, necessarily be resolved in favour of a restoration of the old? Given the character of the ideologies, that can be ruled out - yet not in an absolute sense. Meanwhile physical depression will lead in the long run to a wider scepticism, and a new "arrangement" will be found. (2003, p. 276)

In Gramsci's scenario, the ruling class uses force to block the 'historically normal' passage from one hegemony to another. What they forget is that force is neither the source nor the guarantor of ideology. Without the restoration of the old political-economic order the old ideologies (based, in Williams theory of hegemony, on 'reified' assumption and expectations) will not reassert themselves ${ }^{85}$ and eventually, argues Gramsci, 'a new "arrangement" will be

\footnotetext{
${ }^{85}$ In historical fact, of course, the capitalist class was cannier than to rely solely on force; what restored something broadly comparable to the old social order after WW2 was not the stubborn exertion of state force against rising ideologies but partial capitulation to them under the aegis of social democracy. Gramsci could not
} 
found'. The nature of that arrangement is the contingent element in Gramsci's account of hegemonic transition. Whether the emergent hegemony of the rising class can become dominant, I argue, is dependent upon the success of Williams's war of position, the long revolution, this being the process whereby that class develops the capacity to communicate its own experience (both directly and via the incorporation of formal or abstract cognition) and to manifest this in meanings and values which prefigure a realistic and desirable social order. In keeping with Williams's analysis in $P L$, this must occur both before and after the breakdown of the dominant hegemony; the long revolution is both the preparatory phase of 'learning the skills of popular organization and control' (2015 [1979], p. 422) and the effective capacity to replace the dominant hegemony with the emergent (in practical terms, to resist counter-revolution and begin to construct socialist institutions). The rising class cannot construct the idea of its culture in the timescale of a short revolution; it must already be envisioning, and to some extent already living, its culture.

What makes the difference between success and failure for the rising class? We know that an early goal of Williams's long revolution was the extension of education, especially adult education, to equip the rising class with the tools to articulate their experience (in Sartrean terms, the means to assert concrete particularism). In the seventies and eighties, Williams became increasingly aware that an important part of this capacity-building would be the acquisition of abstract knowledge, whether of structural economic relations, historical events or the interpenetration of distant institutions with local ways of life. And yet, as with Sartrean interiority, Williams always retains the notion that structural/abstract knowledge must itself be incorporated into experience to be politically valid. How is this to be achieved? We know that it cannot be achieved by any of the elite usurpations of knowledge which are Williams's constant enemies: monopolization by the closed circles of bourgeois academia; imputation by revolutionaries; lofty wielding by technocratic Fabians. In all of these, structural knowledge exists outside of the experience of the rising class. But even conscious learning does not fully solve the problem since, as Matthew Price discovers in Border Country, a vast gulf separates the bare knowing of facts and their lived comprehension.

Williams was not a philosopher; he never fully articulated a solution to the epistemological challenges facing the rising class. I contend, however, that his analysis of hegemony in the 
seventies suggests one. Williams's reworking of Gramscian theory clarified that the obfuscating power of capitalism is not simply a function of inequality of access to the means and powers of communication. Hegemony also functions by producing a common sense linked to everyday immersion in a seemingly intractable social order. This means that neither direct experience nor abstract reason will be capable of fully stripping back the sense of basic reality that reification lends to the dominant hegemony. Williams understood that conscious learning about structural forces could help to fill the gaps left by experience (provided such knowledge-processes were not the exclusive purview of elites). But he also recognized that reification, with its construction of a sense of 'absolute because experienced reality', immunizes the social order against the subversive effects of structural knowledge on the part of the rising class. After all, it doesn't matter that exploitation is real and objective if it is also natural and unchangeable, a 'fact of life'. It is this sense of inevitability, more than anything, which needs to be overcome if full emergence is to occur.

This returns us to Gramsci's interregnum scenario which, as I have already noted, offers precisely such an epistemological break; in periods of profound crisis, the social order demonstrates to experience its own fallibility, its non-commonsensical, non-eternal character as a social contingency. In the following passage, the culmination of the interregnum section, Gramsci draws out the implications for consciousness:

From this too one may conclude that highly favourable conditions are being created for an unprecedented expansion of historical materialism. The very poverty which at first inevitably characterises historical materialism as a theory diffused widely among the masses will help it to spread. The death of the old ideologies takes the form of scepticism with regard to all theories and general formulae; of application to the pure economic fact (earnings, etc.) and to a form of politics which is not simply realistic in fact (this is always the case) but which is cynical in its immediate manifestations ... But this reduction to economics and to politics means precisely a reduction of the highest superstructures to the level of those which adhere more closely to the structure itself - in other words, the possibility and necessity of creating a new culture. (2003, p. 276)

During the interregnum, the 'the old ideologies' are replaced by the stark, urgent facts of economic hardship and political upheaval. This leaves a cultural void, potentially to be filled by the meanings, values and practices of the rising class. The capitalist way of life is 'reduced' to those undergirding elements that are most hidden under normal conditions, the class basis of society appearing for the first time in solution: exploitation, violence, the threat of poverty. Gramsci describes this as a 'wave of materialism' (p. 275), a sudden willingness 
to account for social phenomena by their material bases. Crucially, insofar as this results in a flourishing of historical materialism among the working class, this shift in consciousness will have an empirical basis. It will spread not because revolutionary intellectuals have disseminated knowledge downwards, but because social reality itself has become capable of being experienced as having a material foundation.

Gramsci argues that the reduction to materiality announces not just the proliferation of historical materialism, but also the 'possibility and necessity of creating a new culture'. Here at least, Gramsci is using 'culture' in much the same way as Williams, to refer to a whole way of life. What is unique about the interregnum, I would argue, is that the possibility emerges of producing a culture the objectivity of which may be experienced subjectively. The material basis of social reality is made present to lived experience, rather than having to be inferred, imputed or otherwise reasoned into being within consciousness. Suddenly, what Williams had always insisted upon, that knowledge be democratised/incorporated into the experience of the rising class itself, becomes possible. Williams would have resisted Gramsci's orthodox rhetoric i.e. the idea of the 'highest superstructures' being reduced to 'the level of those which adhere most closely to the structure itself'. But we have only to replace 'base and superstructure' with 'social being and consciousness' to read Gramsci's theory of hegemonic breakdown in a manner consonant with cultural materialism. For then what is happening in the interregnum is that a whole complex of things, from meanings and values to social institutions and cultural practices, are rendered visible in terms of their social being, their material and historical reality (this need not be a full transparency to be effective politically). Gramsci's interregnum, in other words, offers hope that a severe enough crisis of capitalism could provide the material conditions (though not necessarily the political or cultural capacity) for a) a definitive triumph over reification and b) that elusive state of 'interiority' theorized in Sartre's Critique as 'dialectical reason' and in Williams's oeuvre as the perspective of totality.

Grasmci's analysis explains why the long revolution was never going to be sufficient on its own, a fact Williams explicitly acknowledged in the 'Two Roads to Change' discussion of 1979. Without a crisis and/or a short revolution, the long revolution, the development of the culture of the rising class remains in its preparatory phase, its pre-emergence. To be sure, the short revolution will come to nothing if the cultural production of the rising class is not already highly advanced. But it requires a crisis of the dominant hegemony to create the 
space for the rising class to render its culture in a new, 'fully emerged' socialist hegemony. Such a position could be characterised as idealist, since it appears to assert that a certain kind of consciousness is the precondition for historical change. But by reading Williams and Gramsci together we can see that it is in fact a realism; it positions the object of perception as the final arbiter of the sufficiency of its perception by any observer. While a particular form of consciousness, which the Marxist tradition has called class consciousness, must 'already' be present for revolution to be made, it is the social being (materiality) of society which determines whether that consciousness is possible in the first place. The essence of Williams's epistemology, what we have variously called realism, dialectical reason or the perspective of totality, is that knowledge arises only out of those cultures the social being of which renders them graspable by experience. The political praxis it recommends is what might be termed a revolutionary culturalism in which the rising class, in concert with a (violent or non-violent) assault on state power, wins hegemony by building and realising a culture consonant with its experience and interests. 


\section{Conclusion}

Perry Anderson's stated reason for excluding Williams from his canon of Western Marxism was that Williams was not, in the end, a Marxist. In the introduction to this thesis I showed that, underlying the 'manifest content' of Anderson's decision was another, more latent cause: Williams could not participate in the Western Marxist tradition because he was British, or rather, because his work bore the stamp of a British intellectual inheritance. The logic of Anderson's theoretical discourse, moreover, dictated that the one imply the other. Williams was not a Marxist because his work was 'British', i.e. empiricist, and his work was 'British' because it was not Marxist, which for Anderson meant a firmly rationalist historical materialism. Where Anderson did find value in Williams's work was in its totalising character which, he argued, was a central feature of European thought but was, Williams aside, practically non-existent in Britain. At the core of Anderson's paradoxical appraisal of Williams as both the great hope of the British left and a symbol of its weakness, then, was the view that one cannot be both a theorist of the totality and an empiricist. Experience, which could know only itself, was the death of knowledge, and what socialists needed was knowledge. And this meant that Williams, whose life's work may be described as the attempt to reconcile experience with the totality, could never be 'our' Western Marxist.

The argument of this thesis has been a two-fold rejoinder to Anderson. First, that if he is right to equate empiricism with a British intellectual inheritance, then any 'British Marxism' will have to incorporate a strong 'native' (i.e. empiricist) element or else amount to a mass continental import. I think we can take from Anderson's eagerness to discover in Williams an 'indigenous' Marxism that he understood this; his theoretical presuppositions, however, meant that he could not unreservedly name Williams's work as 'it'. The second argument of this thesis against Anderson, and which the bulk of it is devoted to, is that Williams was not the monolithically British thinker Anderson and his contemporaries believed him to be. In the first instance, Williams's preoccupation with totality is itself a 'rationalist' impulse, firmly aligning him the European traditions Anderson praises, especially the Western Marxists. In addition, Williams was, from at least The Long Revolution, profoundly influenced by European thinkers, centrally and formatively so from 1968. That Williams never lost his 'British' affinity with experience does not negate the fact that, from the earliest days of $N L R$, Williams's was a totalising and in many respects a 'rationalist' thought highly critical of 
English academic orthodoxy even where it shared, for historical and personal reasons, a somewhat insular frame of reference.

The perception that Williams was an insular British thinker unmoved by European intellectual trends was mirrored by the suspicion that he was a political and/or cultural nationalist, and therefore an insubstantial ally of the venerable tradition of internationalist socialism. The fact is that Williams viewed both nationalism and internationalism as insufficient in their traditional guises as 'unified national polity' and 'unified proletariat without nations'. What mattered was self-determination and democracy, the closeness of power to given communities of experience. The enemy of democracy was not the nation but that dominant culture within the nation which overwrote its own subaltern experiences, the forest of 'abstract universality' for which the trees of 'concrete particularism' could not be seen. The dominant English culture which Williams learned about at Cambridge, moreover, was characterised by disdain for totalising forms of thought and analysis, by strict specialisation of intellectual disciplines and a refusal to engage with the kinds of necessary abstraction and sociological bridge-building which Williams thought necessary for social analysis. The result was that the European thinkers and ideas which were becoming increasingly important for Williams were doing so in part because they signalled an alternative to those reified models of cognition which, to Williams's mind, suffused the dominant culture, and which were in fact woven through the values, meanings and practices of the British ruling class.

Williams's Europeanism was, from the early seventies, inseparable from his increasing identification with his Welsh roots. In the phrase 'Welsh European', Williams fused the two elements in his mature formation which stood in opposition to the dominant English intellectual culture in which he had been immersed. Wales, which had figured in Williams's earlier work as both a narrative setting for experiential/epistemological conflict in the novels and as a model for the 'common culture', now became a symbol for the emergent, for the alternative or oppositional in British culture. Wales was one example among many of a concrete particularism obscured and marred by the abstract universality of English cultural and political domination. Its almost symbiotic link to Williams's Europeanism may then be explained by analogy to the dependency Sartre intuited between Basque self-determination and the kind of socialist internationalism that could also incorporate the Spanish and French; concrete universality, real unity, was only possible between self-determining entities fully 
recognised as equals. In Williams's theoretical discourse, both Wales and Europe are 'emergent' elements, insofar as they appear to the dominant English/British discourse as aberrant or subversive. But Europe, which Williams associates with a totalising form of reason inimical to an 'analytic' English intellectual culture, also comes to play the part of universality; it symbolises that larger aggregation of entities or emergent impulses promised by the vision of concrete universality. The basic universalizing impulse of the (Welsh) common culture was transferred, in the seventies, to a heterogeneous Europe, leaving Wales as the paradigmatic example of the sort of entity which a new internationalism (Williams's 'variable socialism') would seek to integrate. 'Welsh Europeanism', then, named the political geography of Williams's reconciliation of experience with the totality.

As I outlined in the introduction, Williams was influenced by a wide range of European thinkers, not all of them Marxists. It is nevertheless clear that European Marxism, particularly the Western Marxist tradition, was of the greatest significance for Williams's overall development. This, I have argued, was primarily due that tradition's preoccupation with the concept of totality. While almost every thinker associated with Western Marxism was a 'totalizer' of one form or another, the trio Williams described as Marxism's 'alternative tradition' were connected to the concept in ways which made them particularly germane. Lukacs and Gramsci may be regarded (with Korsch) as originators and popularisers of the general Western Marxist concern with totality; as such, their writings contain the visible seeds of a growth beyond the mechanical assumptions of orthodox Marxism which could not have been more salient to the British New Left in the fifties and sixties. Sartre, coming later, developed a less politically grandiose version of totality which presaged theoretical developments beyond Western Marxism; this appealed to Williams who, while profoundly influenced by the tradition, was not originally 'of' it and was also engaged in its critique. Foregoing either the cultural pessimism of the Frankfurt School or the militantly philosophical anti-humanism of Althusser, these three thinkers, for all their differences, infused Marxism (European and British) with an analysis of the relation between consciousness (experience) and society, culture and social change which was sorely lacking, and which was invaluable to Williams's sense of his own project.

Lukacs's conception of the totality was as the unification of parts; the perspective of totality was thus the enemy of reification, that atomised and fragmentary appearance of things which had its source in commodity fetishism (the mistaking of relations between people as relations 
between things) under capitalism. On this, Williams could not have been more in agreement, and Lukacs's writings on literary realism left him with a profound sense of both the desirability and difficulty of representing social relations in their totality. Williams agreed with Lukacs that the subjective bias of much modernist writing, its willful inattention to totality, was a flaw. The severity of Lukacs's, critique, however, its insistence on the 'decadence' of modernism revealed a conception of the roots of totality which Williams could not accept: the orthodox Marxist position that cultural products and phases are finally explicable as the effects of classes in their practical relation to an 'epochal' model of history. The publication of History and Class Consciousness was a key event for British Marxists, and Williams found much to agree with in its critique of reification and advocacy of 'total' analysis. I have argued that Williams's critique of Lukacs's distinction between actual and imputed consciousness suffered from an error stemming from the influence of Goldmann. Williams read 'actual' consciousness as an admission by Lukacs that some forms of consciousness evade capture by the dominant system of meanings and values, that is, that consciousness is generative and creative. 'Imputed' consciousness was then this emergent, potentially subversive consciousness raised to the point of apprehending the totality, the point of 'coherence' (a term of Goldmann's). This was quite distant from Lukacs's intention, which was simply to show that the 'spontaneous' consciousness of the working class was inadequate relative to the proper awareness of interests (class consciousness) which could be 'imputed' to it by socialists and intellectuals. While Williams misread Lukacs on this point, the conception of 'actual' consciousness which Williams took away was undoubtedly an influence on his later theorisation of the 'emergent', that sector of a culture which was alternative or oppositional to the dominant paradigm. Lukacs also provided Williams with a strong negative clarification of his own militant anti-elitism. A consciousness 'imputed' from on high, whether as 'coherence' or 'awareness of interests', would only reproduce the oppression of the working-class; a democratic socialist politics would require the totality to be brought within the range of possible experience.

Sartre's conception of the totality was very close to Williams's, as the 'interiority' or presence in consciousness of those objective material relations human beings both produce and are produced by. This was precisely the element which was lacking in Lukacs: a firm 
insistence on the reconcilability of the totality with experience. ${ }^{86}$ In the early Sartre, however, Williams's found a thinker producing original work within a phenomenological tradition that bore too many of the hallmarks of a bourgeois subjectivism. For Williams, Sartre the expressionist playwright (and the existentialist philosopher) joined a venerable tradition of tragic writing and theory in which the individual and society were set into a relation of neartotal antagonism. Sartre's plays, with their metaphysical rebellions and pessimistic denouements, expressed the inability of the modern tragic tradition to conceive of collective routes to the resolution of social disorder. While Brecht's dramatic art went much further than Sartre's in empowering a critical humanist subject, he too fell prey to the expressionist structure of feeling. In Sartre's later work, the liberal-expressionist deadlock (if not necessarily the Marxist-existentialist one) was resolved in favour of a totalising philosophical project with which Williams was in firm agreement and which, I have argued, influenced both his late essays on commitment in art and his positions on the politics of place. Williams shared with the late Sartre a conception of individuality deeply at odds with bourgeois individualism, and thus with the notion of the 'free' artist who acts without social or psychological constraint. Williams's aesthetic essays of the seventies and eighties critiqued the early Sartre's notion of socialist political commitment in art from a position which drew on the Sartre of the Critique; what the writer must 'commit' to is neither his own freedom nor a specific political cause, but rather what is emergent in his creative response to the world. 'Committed' art, like political praxis in the Critique, is figured as the outcome of a dialectical and totalising relation between subject and object, experience and 'abstract' reason. Sartre's essay 'The Burgos Trials', meanwhile, influenced Williams in a similar direction in the political sphere. A totalising perspective demanded that Williams's old concept of the common culture be dropped in favour of that 'common operation of all particularisms' which Sartre had argued was the only ground of 'a true universalism'.

In Gramsci, Williams encountered the limits of the totality conceived apolitically. Gramsci's conception of totality was as antegrated field of political struggle. As such, it also posed a

\footnotetext{
${ }^{86}$ It should be noted that, for both Sartre and Williams, the potential reconcilability of objective reality (Sartre's 'practico-inert') with experience is no guarantee of revolution, much less of history as a whole being intelligible or directed. As Jay (1984, pp. 331-360) recounts, Sartre distinguished between 'totality' and 'totalisation', between the simple existence of a 'whole', theoretically discernable by dialectical reason, and the prospect of 'totalisation', of man/history actually behaving in a 'total' manner, as a 'unified and intelligible whole' (p. 353). The unstable or non-total character of things implied by Sartre's totalisation finds a parallel in Williams's insistence, via his 'residual, dominant, emergent', on the shifting and contradictory nature of the component parts of any given culture.
} 
question to the more epistemologically-oriented conceptions of totality which Williams had imbibed from Lukacs, Goldmann and Sartre: how is the 'perspective of totality' concretely to be achieved and, once it is, how might it be converted into a successful assault on the cultural domination exerted by the capitalist class? Gramsci (one of the few Western Marxists who was not a professional philosopher) reinserted the question of power and domination into the problematic of totality, and Williams's original theorization of hegemony was an attempt to tackle this question head-on. Hegemony as described by Williams was perhaps the clearest example of a synthetically 'Anglo-European' position to emerge from Williams's ongoing project of reconciling the totality to experience. Williams's was an empiricist Gramscianism, a redirection of the energy of Gramsci's hegemonic edifice, constructed as it was from some combination of capitalist 'leadership' and control of cultural and other institutions, towards a diffuse experiential formation, a 'sense of absolute because experienced reality' which I have argued is closer to reification in its customary usage. Williams's work contained Gramscian elements from much earlier than his engagements with hegemony in the seventies. I have argued that Williams's concept of a 'long revolution' bears a striking resemblance to Gramsci's 'war of position', the class struggle at the level of culture; both are what might be termed 'experiential preparations' for the short revolution or 'war of manoeuvre'. Williams's work is more explicit than Gramsci's in stating that the long revolution is also an essential period of socialist prefiguration, in which the experience of the 'rising class' develops from a state of 'pre-emergence' to one which is capable of seizing upon the opportunity to fundamentally transform society.

Throughout this thesis, I have affirmed Williams as both an aesthetic and a philosophical realist. I have also affirmed Williams's own description of his work as a fusion of materialist and idealist elements. The relation between these two statements requires a little unpacking, for the former is not the resolution of the latter. It is Williams's epistemology, not his ontology, which is realist and this, as the entire argument of this thesis implies, is one form of resolution of the empiricism/rationalism dichotomy upon which the interpretation of elements in Williams's work as 'British' or 'European' relies. Experience, in the final analysis, is our primary window on to the world; nevertheless, the world exists independently of our cognition. 'Rational' or abstract reasoning permits us to intuit, in a limited way, something of this non-experiential objectivity, but only insofar as it presents its findings to experience, that is, insofar as it can be related, made compatible with or integrated into experience. This, of course, is the process of reconciling experience to the totality which I have argued was 
Williams's primary concern. Ontologically, Williams is primarily a materialist; he believes in the material nature of reality and conceives of consciousness as a kind of 'embeddedness' in a social-material world which pre-exists and outlives the individual human being. The 'idealist' element in Williams's work is not idealism in the sense familiar to philosophy, i.e. the Platonic/Berkeleyan commitment to 'ideas' which exist independently of material bodies or even of consciousness. What has been described as Williams's idealism is finally, I think, the combination of his empiricism (centring of subjective apprehension) with his political insistence that the achievement of socialism will be dependent upon its prefiguration as an 'idea' in the self-generative emergence of the culture of the working class. But there is nothing there that is incompatible with a robust and realist materialism.

Relative to the existing critical literature, my thesis asserts a stronger and more formative European Marxist influence on Williams than has generally been supposed; in this it joins more recent scholarship in developing the contributions of specific European thinkers to Williams's development. While many critics have noted Williams's 'Welsh Europeanism', I have tried to provide a firmer theoretical underpinning for that combination of signifiers. This thesis has challenged those readings of Williams which figure him as either a) an Anglophile nationalist or unionist, b) a Welsh nationalist or a c) a broad-brush internationalist; the reality is clearly more complex. Against the grain of the Nairn-Anderson theses and indeed the assumptions of much later scholarship, I assert a stronger British participation in, even membership of, the Western Marxist tradition in Williams's personage. My analysis confirms the consensus that Williams was influenced by Lukacs, but develops this account considerably using evidence from a broad range of Williams's writings, in particular the reviews, which have received little attention. I have argued for a very strong Sartrean influence, in contrast to a largely silent literature, and have made the case for heretofore unexplored direct influences with 'The Burgos Trials' and the Critique; here again, the reviews were critical. While critics have been most forthcoming in attributing a strong influence to Gramsci, this thesis has explored Gramsci's impact on Williams to greater theoretical depth and argued for its close connection with the empiricist/rationalist dialectic which informed Williams's approach to totality. In contrast with commonplace accounts of Williams's 'gradualism' or 'culturalist' inattention to revolution, I have affirmed Williams as a revolutionary socialist and detected a putative revolutionary theory in Williams's work on hegemony. 
There are several avenues of future research which, to my mind, suggest themselves. The first and most obvious would be to extend the kind of detailed analysis and comparison performed here to thinkers beyond Marxism's 'alternative tradition'. More work needs to be done on the influence of the Frankfurt School on Williams, in particular Fromm, Adorno, Marcuse and Benjamin. Williams's views on psychoanalysis were largely negative; a thorough analysis of why this was so would be useful. While I have briefly discussed the late influence of thinkers such as Bourdieu, Timpanaro and Bakhtin on Williams, research looking specifically at later European influences (i.e. in the eighties) would extend the present analysis and suggest where Williams's unique approach might have taken him had he outlived the eighties. A second and related project would be to apply the comparative and trans-national analysis employed here to other figures in the post-war British New Left. While I have gone into some detail on Anderson's relation to European thought, extended analyses of the influence of European thinkers on figures such as Eagleton, Hall, Miliband, Barnett and Thompson would significantly extend the present account of Anglo-European intellectual transmission.

The question of Williams's realism is, I think, a paramount question for future research. I have discussed this at various points, but a thorough analysis of the links between Williams's aesthetic and philosophical realism in a range of texts, and crucially by relating this to his novels, would be invaluable. Such an analysis would benefit from situating Williams's thought within a broader 'realist' theoretical literature extending to the present day. In recent years, the study of realism has found itself centre-stage in both philosophy and cultural studies, not least through the work of Roy Bhaskar ${ }^{87}$ and the 'speculative realist ${ }^{88}$ philosophy of thinkers like Ray Brassier and Graham Harman. This has coincided, in the post-crash era, with a general turn away from postmodernist and poststructuralist forms of analysis and towards a new concern with materialist analysis, ${ }^{89}$ including a revival of academic Marxism. Williams has not, to my knowledge, been much discussed as a precursor of such heterodox materialist and realist trends; my analysis in this thesis suggests this as a fruitful area for further work. A fourth area for future study is closely related to this, namely the influence of Williams's thought on what might broadly be described as a shift away from ideology-based theories of class rule and toward accounts based on reification within Marxist theory since the

\footnotetext{
${ }^{87}$ See Collier, A. (1994) Critical Realism: An Introduction to Roy Bhaskar's Philosophy for a relevant introduction.

${ }^{88}$ For an introductory collection, see Bryant, L., Harman, G. \& Srnicek, N. (eds.) (2011) The Speculative Turn: Continental Materialism and Realism.

${ }^{89}$ See, for example, Cooler, D. \& Frost, S. (eds.) (2010) New Materialisms: Ontology, Agency, and Politics.
} 
seventies. Marxist theorists from Slavoj Zizek to Mark Fisher and Vivek Chibber have participated in a problematisation of the link, most firmly expressed in Althusserianism, between ideology, in the sense of conscious beliefs, and action and/or political change. ${ }^{90} \mathrm{In}$ Chapter Three of this thesis I showed that Williams's empiricist Gramscianism, which was indeed hostile to Althusserian versions of ideology, was closer in many ways to a theory of reification, the sense of 'absolute because experienced reality' which limits the range of the thinkable and appears to set rigid limits to the doable. ${ }^{91}$ While the work of Chibber, for example, arguably 'over-excludes' conscious, ideological beliefs from the formula of social oppression, Williams work on hegemony in the seventies may be considered an early forerunner of this kind of Marxist analysis.

A final and more urgent area for further research is the need for thorough analysis of Williams's enormous back-catalogue of reviews. In this thesis I made only shallow inroads even into the reviews on European thinkers. Williams wrote hundreds of reviews on a massive number of texts, thinkers and topics. The ideas contained therein, while they will in many cases be reproductions in another format of insights originating in Williams's books and articles, may nevertheless be central for understanding various aspects of Williams's work. I know that I could not have written this thesis without the reviews on Lukacs, Sartre and others; indeed, it might not have been a viable project at all without them. While Williams's identification as a 'Welsh European' appeared in book form, its essential character, which it has been the purpose of this thesis to discern, was discoverable only via the reviews. There will undoubtedly be other areas of Williams's work in which much of the central material is in the reviews and nowhere else.

\footnotetext{
${ }^{90}$ See, for example, Zizek, S. (2008) The Sublime Object of Ideology, Fisher, M. (2009) Capitalist Realism: Is There No Alternative? \& Chibber, V. (2013) Postcolonial Theory and the Specter of Capital.

${ }^{91}$ Fisher's Capitalist Realism is effectively a book-length excursus on this predicament.
} 


\section{Bibliography}

Ahmad, A. (2008). In theory: Classes, nation, literatures ( $2^{\text {nd }}$ ed.). London: Verso.

Adorno, T. (1973). Negative dialectics. Abingdon: Routledge.

Adorno, T. (2005). Minima moralia: Reflections on a damaged life. London: Verso.

Adorno, T. (2007). Commitment. In T. Adorno, W. Benjamin, E. Bloch, B. Brecht \& G. Lukacs (Eds.), Aesthetics and politics ( $2^{\text {nd }}$ ed.) (pp. 177-196). London: Verso.

Adorno, T. \& Horkheimer, M. (1997). Dialectic of enlightenment (2nd ed.). London: Verso.

Althusser, L. (2008). On ideology. London: Verso.

Althusser, L. (2009). For Marx (B. Brewster, Trans.). London: Verso.

Althusser, L. \& Balibar, E. (2009). Reading capital ( $3^{\text {rd }}$ ed.). London: Verso.

Anderson, B. (2016). Imagined communities: Reflections on the origin and spread of nationalism. London: Verso.

Anderson, P. (1966). Socialism and pseudo-empiricism. New Left Review, vol. I/35 (JanuaryFebruary), pp. 2-42.

Anderson, P. (1968). Components of the national culture. New Left Review, vol. I/50 (JulyAugust), pp. 3-57.

Anderson, P. (1976). The antinomies of Antonio Gramsci. New Left Review, vol. I/100 (November-December), pp. 5-78.

Anderson, P. (1980). Arguments within English Marxism. London: Verso.

Anderson, P. (1983). In the tracks of historical materialism. London: Verso.

Anderson, P. (1987). Considerations on Western Marxism (4 ${ }^{\text {th }}$ ed.). London: Verso.

Anderson, P. (2007). Spectrum: From right to left in the world of ideas ( $2^{\text {nd }}$ end.). London: Verso.

Anderson, P. (2016). Heirs of Gramsci. New Left Review, vol. 100 (July-August), pp. 71-97.

Anderson, P. (2017) The h-word: The peripeteia of hegemony. London: Verso.

Aronowitz, S. (1992). On Catherine Gallagher's critique of Raymond Williams. Social Text, vol. 30, pp. 90-97.

Aronson, R. (1983). The individualist social theory of Jean-Paul Sartre. In New Left Review (Ed.), Western Marxism: A critical reader (2 ${ }^{\text {nd }}$ ed.) (pp. 201-232). London: Verso. 
Bahro, R. (1977). The alternative in Eastern Europe. New Left Review, vol. I/106 (NovemberDecember), pp. 3-37.

Bakhtin, M. (2011a). Discourse in the novel (C. Emerson \& M. Holquist, Trans.). In M. Holquist (Ed.), The dialogic imagination: Four essays by Mikhail Bakhtin (pp. 249422). Texas: University of Texas Press.

Bakhtin, M. (2011b). Epic and novel (C. Emerson \& M. Holquist, Trans.). In M. Holquist (Ed.), The dialogic imagination: Four essays by Mikhail Bakhtin (pp. 3-40). Texas: University of Texas Press.

Barnett, A. (1976). Raymond Williams and Marxism: A rejoined to Terry Eagleton. New Left Review, vol. I/99 (September-October), pp. 47-64.

Barnes, H. E. (1974). Sartre. London: Quartet Books.

Barnes, H. E. (1982). Sartre and Flaubert. Chicago: University of Chicago Press.

Barthes, R. (2009). Mythologies ( $2^{\text {nd }}$ ed.) (J. Cape, Trans.). London:Vintage.

Barthes, R. (2012). Writing degree zero (2 ${ }^{\text {nd }}$ ed.) (J. Cape, Trans.). New York: Hill and Wang.

Bauman, Z. \& Bordoni, C. (2014). State of crisis. Cambridge: Polity Press.

Beaudrillard, J. (1994). Simulation and simulacra (S. Glaser, Trans.). Michigan: University of Michigan Press.

Benjamin, W. (1999). Harcourt, Brace \& World Inc. trans., Illuminations, London: Pimlico.

Benjamin, W. (2007). Reply. In T. Adorno, W. Benjamin, E. Bloch, B. Brecht \& G. Lukacs (Eds.), Aesthetics and politics (2 ${ }^{\text {nd }}$ ed.) (pp. 134-141). London: Verso.

Benjamin, W. (2010). The work of art in the age of its mechanical reproducibility. In V. B. Leitch, W. E. Cain, L. A. Finke, A. E. Johnson \& J. McGowan (Eds.), The Norton anthology of theory and criticism ( $2^{\text {nd }}$ ed.). London: W. W. Norton \& Company Ltd.

Best, A., Hanhim 臾i J. M., Maiolo, J. A. \& Schulze, K. E. (2008). International history of the twentieth century and beyond ( $2^{\text {nd }}$ Ed.). Oxon: Routledge.

Bidet, J. (2008). Bourdieu and historical materialism (G. Elliot, Trans.). In J. Bidet \& S. Kouvelakis (Eds.), Critical companion to contemporary Marxism (pp. 587-604). Leiden: Koninklijke Brill NV.

Blackburn, R. (1988). Raymond Williams and the politics of a new left. New Left Review, vol. I/168 (March-April, pp. 12-22. 
Bloch, E. (2007). Discussing expressionism. In T. Adorno, W. Benjamin, E. Bloch, B. Brecht \& G. Lukacs (Eds.), Aesthetics and politics ( $2^{\text {nd }}$ ed.) (pp. 16-27). London: Verso.

Bobbio, N. (2005a). Left \& right: The significance of a political distinction ( $2^{\text {nd }}$ ed.) (Polity Press, Trans.). Cambridge: Polity Press.

Bobbio, N. (2005b). Norberto Bobbio: Liberalism and democracy $\left(2^{\text {nd }}\right.$ ed.) (Verso, Trans.). London: Verso.

Bourdieu, P. (1976, December 22). Personal Correspondence. This item is among the papers of Raymond Williams, held in the Richard Burton Archives at Swansea University.

Bourdieu, P. (1977, December 7). Personal Correspondence. This item is among the papers of Raymond Williams, held in the Richard Burton Archives at Swansea University.

Bourdieu, P. (2004). The field of cultural production: Essays on art and literature $\left(6^{\text {th }} \mathrm{ed}.\right)$. Cambridge: Polity Press.

Bourdieu, P. (2010). Distinction: A social critique of the judgement of taste. Abingdon: Routledge.

Brecht, B. (1997). A short organum for the theatre. In J. Willet (ed.), Brecht on theatre: The development of an aesthetic (pp. 179-208). (J. Willet, Trans.), London: Methuen.

Brecht, B. (1997). The modern theatre is the epic theatre. In J. Willet (ed.), Brecht on theatre: The development of an aesthetic (pp. 33-42). (J. Willet, Trans.), London: Methuen.

Brecht, B. (1998). The good person of Szechwan (S. S. Brecht. Trans.). In R. Manheim \& J. Willett (eds.) Brecht: Collected Plays, Vol. 6 (pp. 1-112). London: Methuen.

Brecht, B. (2000). The threepenny opera (R. Manheim \& J. Willet, Trans.). London: Methuen.

Brecht, B. (2006). The life of Galileo (J. Willett. Trans.). London: Methuen.

Brecht, B. (2007). Against Georg Lukacs. In T. Adorno, W. Benjamin, E. Bloch, B. Brecht \& G. Lukacs (Eds.), Aesthetics and politics (2nd ed.) (pp. 28-59). London: Verso.

Brecht, B. (2013). Mother courage and her children (J. Willet, Trans.). London: Bloomsbury Methuen Drama.

Brenkman, J. (1995). Raymond Williams and Marxism. In C. Prendergast (ed.), Cultural materialism: On Raymond Williams (pp. 237-267). Minnesota: University of Minnesota Press.

Bree, G. (1972). Camus and Sartre: Crisis and commitment. New York: Delacorte Press.

Bryant, L., Harman, G. \& Srnicek, N. (eds.) (2011). The speculative turn: Continental materialism and realism. Melbourne: re.press. 
Butler, J. (2008). Gender trouble: Feminism and the subversion of identity. New York: Routledge.

Butler, J. (1988). Performative acts and gender constitution: An essay in phenomenology and feminist theory. Theatre Journal, vol. 40(4), 519-531.

Butler, J., Laclau, E. \& Zizek, S. (2000). Contingency, hegemony, universality: Contemporary dialogues on the left. London: Verso.

Calhoun, C. (1990). Putting the sociologist in the sociology of culture: The self-reflexive scholarship of Pierre Bourdieu and Raymond Williams. Contemporary Sociology: A Journal of Reviews, vol. 19(4), pp. 500-505.

Chibber, V. (2013). Postcolonial theory and the specter of capital. London: Verso.

Cohen, G . A. (2001). Karl Marx's theory of history: A defence. Oxford: Oxford University Press.

Colletti, L. (1983). A political and philosophical interview. In New Left Review (Ed.), Western Marxism: A critical reader ( $2^{\text {nd }}$ ed.) (pp. 3-28). London: Verso.

Collier, A. (1994). Critical realism: An introduction Roy Bhaskar's philosophy. London: Verso.

Collini, S. (2002). Defending cultural criticism. New Left Review, vol. 18 (NovemberDecember), pp. 73-97.

Collini, S. (2007). Absent minds: Intellectuals in Britain. Oxford: Oxford University Press.

Congdon, L. (1983). The young Lukacs. Chapel Hill: University of North Carolina Press.

Cooler, D. \& Frost, S. (Eds.) (2010). New materialisms: Ontology, agency, and politics. Durham: Duke University Press.

Culler, J. (2002). Barthes: A very short introduction. Oxford: Oxford University Press.

Cumming, R. D. (Ed.) (2003). The philosophy of Jean-Paul Sartre. New York: Random House.

de Beauvoir, S. (1984). Adieux: A farewell to Sartre. New York: Random House.

Deleuze, G. \& Guattari, F. (2005). A thousand plateaus: Capitalism and schizophrenia (B. Massumi, Trans.). Minneapolis: University of Minnesota Press.

Deleuze, G. \& Guattari, F. (2012). Anti Oedipus: Capitalism and schizophrenia (R. Hurley, M. Seem \& H. R. Lane, Trans.). Minneapolis: University of Minnesota Press.

Derrida, J. (1997). Of grammatology ( $2^{\text {nd }}$ ed.) (G. C. Spivak, Trans.). Baltimore: The Johns Hopkins University Press. 
Derrida, J. (2006). Spectres of Marx ( $2^{\text {nd }}$ ed.) (Routledge, Trans.). Oxon: Routledge.

Dix, H. (2010). The pedagogy of cultural materialism: Paulo Freire and Raymond Williams. In Grossberg, L, Horak, R. \& Seidl, M. (eds.) About Raymond Williams. Abingdon: Routledge.

Dix, H. (2013). After Raymond Williams: Cultural materialism and the break-up of Britain ( $2^{\text {nd }}$ ed.). Cardiff: University of Wales Press.

During, S. (1989). After death: Raymond Williams in the modern era. Critical Inquiry, vol. 15(4), pp. 681-703.

Eagleton, T. (1976), Criticism and politics: The work of Raymond Williams. New Left Review, vol. I/95 (January-February), pp. 3-23.

Eagleton, T. (1986). Criticism and ideology. London: Verso.

Eagleton, T. (2002). Marxism and literary criticism ( $2^{\text {nd }}$ ed.). London: Routledge.

Eagleton, T. (2004). After theory. London: Penguin Books Ltd.

Eagleton, T. (2007a). Base and superstructure in Raymond Williams. In T. Eagleton (Ed.), Raymond Williams: Critical perspectives ( ${ }^{\text {rd }}$ ed.) (pp. 165-175). Cambridge: Polity Press.

Eagleton, T. (2009). Walter Benjamin or towards a revolutionary criticism. London: Verso.

Eagleton, T. (2010). Literary theory: An introduction (4 ${ }^{\text {th }}$ ed.). Oxford: Blackwell.

Engels, F. \& Marx, K. (1998). The German ideology. New York: Prometheus Books.

Engels, F. \& Marx, K. (2008). The communist manifesto ( ${ }^{\text {rd }}$ ed.) (S. Moore, Trans.). Oxford: Oxford University Press.

Fanon, F. (2001). The wretched of the earth ( $4^{\text {th }}$ ed.). London: Penguin Books Ltd.

Ferrara, F. (2007). Raymond Williams and the Italian left. In T. Eagleton (Ed.), Raymond Williams: Critical perspectives ( $3^{\text {rd }}$ ed.) (pp. 95-107). Cambridge: Polity Press.

Fink, B. (1995). The Lacanian subject: Between language and jouissance. West Sussex: Princeton University Press.

Firat, A.F. \& Venkatesh, A. (1995). Liberatory postmodernism and the reenchantment of consumption. Journal of Consumer Research, vol. 22(3), pp. 239-267.

Fisher, M. (2009). Capitalist realism: Is there no alternative?. Hants: O Books.

Forgacs, D. (1989). Gramsci and Marxism in Britain. New Left Review, vol. I/176 (JulyAugust), pp. 70-88. 
Foucault, M. (1991). The Foucault reader, Rabinow, P. ed., $2^{\text {nd }}$ ed., London: Penguin Books Ltd.

Foucault, M. (2002). The order of things: Archeology of the human sciences $\left(2^{\text {nd }} \mathrm{ed}.\right)$ (Tavistock \& Routledge, Trans.). London: Routledge.

Foucault, M. (2008). Archaeology of knowledge ( $9^{\text {th }}$ ed.) (Tavistock Publication Ltd., Trans.). Oxon: Routledge.

Fowler, B. (2000). The cultural theory of Bourdieu and Williams. Keywords: A Journal of Cultural Materialism, vol ?(3), pp. 109-127.

Freud, S. (1997). The interpretation of dreams (A. A. Brill, Trans.). Ware: Wordsworth Editions Ltd.

Friedman, M. (2002). Capitalism and freedom ( $3^{\text {rd }}$ ed.). London: The University of Chicago Press Ltd.

Fromm, E. (2001). The fear of freedom. Abingdon: Routledge.

Fukuyama, F. (2012). The end of history and the last man ( $2^{\text {nd }}$ ed.). London: Penguin Books Ltd.

Gallagher, C. (1992a). Raymond Williams and cultural studies. Social Text, no. 30, pp. 79-89.

Gallagher, C. (1992b). Response to Aronowitz and Ross. Social Text, no 31/32, pp. 283-285.

Gardner, A. (1999). Routledge Philosophy Guidebook to Kant and the Critique of Pure Reason. Oxon: Routledge.

Garnham, N. \& Williams, R. (1980). Pierre Bourdieu and the sociology of culture: An introduction. Media, Culture and Society, no. 2, pp. 209-23.

Geras, N. (1983). Althusser's Marxism: An assessment. In New Left Review (Ed.), Western Marxism: A critical reader ( $2^{\text {nd }}$ ed.) (pp. 232-272). London: Verso.

Glock, H. (2008). What is analytic philosophy? Cambridge: Cambridge University Press.

Glucksman, A. (1983). A ventriloquist structuralism. In New Left Review (Ed.), Western Marxism: A critical reader (2 ${ }^{\text {nd }}$ ed.) (pp. 273-314). London: Verso.

Goldmann, L. (1975). Towards a sociology of the novel. London: Tavistock Publications Ltd.

Goldmann, L. (2009). Lukacs and Heidegger: Towards a new philosophy (2 ${ }^{\text {nd }}$ ed.) (W. Q. Boelhower, Trans.). Oxon: Routledge.

Goldstein, P. (2005). Post-Marxist theory: An introduction. Albany: State University of New York Press. 
Gorz, A. (1983). Sartre and Marx. In New Left Review (Ed.), Western Marxism: A critical reader $\left(2^{\text {nd }}\right.$ ed.) (pp. 201-231). London: Verso.

Gramsci, A. (1999). The Antonio Gramsci reader: Selected writings 1916-1935. London: Lawrence and Wishart Ltd.

Gramsci, A. (2003). Selections from the prison notebooks. Q. Hoare. \& G. N. Smith (eds.) (Q. Hoare \& G. N. Smith, Trans.). London: Lawrence and Wishart.

Hall, S. (1980). Cultural studies: Two paradigms. Media, Culture and Society, no. 2, pp. 5772.

Hall, S. (1990). The hard road to renewal. London: Verso.

Hall, S. (2010). Cultural Studies and its theoretical legacies. In V. B. Leitch, W. E. Cain, L. A. Finke, A. E. Johnson \& J. McGowan (Eds.), The Norton anthology of theory and criticism $\left(2^{\text {nd }}\right.$ ed.). London: W. W. Norton \& Company Ltd.

Hamilton, S. (2011). The crisis of theory: E. P. Thompson, the new left and postwar politics. Manchester: Manchester University Press.

Hardt, M. \& Negri, A. (2001). Empire. Massachusetts: Harvard University Press.

Hardt, M. \& Negri, A. (2006). Multitude. London: Penguin Books.

Harvey, D. (1995). Militant particularism and global ambition: The conceptual politics of place, space and environment in the work of Raymond Williams. Social Text, no. 42, pp. 69-98.

Harvey, D. (2007). A brief history of neoliberalism. Oxford: Oxford University Press.

Harvey, D. (2010). A companion to Marx's capital. London: Verso.

Hayek, F. (2001). The road to serfdom. London: Routledge.

Hegel, G. W. F. (1977). Phenomenology of spirit (A. V. Miller, Trans.). Oxford: Oxford University Press.

Hegel, G. W. F. \& Houlgate, S. (1998), The Hegel Reader, Stephen Houlgate ed., Oxford: Blackwell.

Heidegger, M. (2010). Being and time (J. Stambaugh, Trans.). New York: State University of New York Press.

Heller, A. (1983). Lukacs revalued. New Jersey: Wiley-Blacwell.

Higgins, J. (1983). Raymond Williams and the problem of ideology. boundary 2, vol. 11(1/2), pp. 145-154. 
Higgins, J. (2005). Raymond Williams: Literature, Marxism and cultural Materialism $\left(2^{\text {nd }}\right.$ ed.). Oxon: Routledge.

Hobsbawm, E. (2003). Age of extremes: The short twentieth century 1994-1991. London: Abacus.

Hughes, H. S. (2008). Consciousness and society: The reorientation of European social thought. New Brunswick: Transaction.

Inglis, F. (1995). Raymond Williams. London: Routledge.

Inwood, M. (2000). Heidegger: A very short introduction (2 ${ }^{\text {nd }}$ ed.). Oxford: Oxford University Press.

Jacoby, R. (2002). Dialectic of defeat: Contours of Western Marxism. Cambridge: Cambridge University Press.

Jameson, F. (1984). Sartre: The origins of a style. New York: Columbia University Press.

Jameson, F. (1991). Postmodernism: Or, the cultural logic of late capitalism. Durham: Duke University Press.

Jameson, F. (2002). The political unconscious: Narrative as a socially symbolic act (2 $\left.{ }^{\text {nd }} \mathrm{ed}.\right)$. Oxon: Routledge.

Jay, M. (1984). Marxism and totality. Berkeley: University of California Press.

Jones, G. S. (1983). The Marxism of the early Lukacs. In New Left Review (Ed.), Western Marxism: A critical reader (2 ${ }^{\text {nd }}$ ed.) (pp. 11-60). London: Verso.

Jones, P. (2004). Raymond Williams and sociology of culture: A critical reconstruction. Basingstoke: Palgrave MacMillan.

Kant, I. (2007). Critique of pure reason (M. Weigelt, Trans.). London: Penguin Books Ltd.

Kagarlitsky, B. (2000). The suicide of the new left. International Socialism, vol. 2(88) (Autumn).

Keuchayan, R. (2013). The left hemisphere: Mapping critical theory today (G. Elliot, Trans.). London: Verso.

Korsch, K. (2012). Marxism and philosophy (F. Haliday, Trans.). London: Verso.

Lacan, J. (1999). Ecrits: The first complete edition in English (B. Fink, Trans.). New York: W.W. Norton and Company, Inc.

Lacan, J. (1998). The seminar of Jacques Lacan, book XI: The four fundamental concepts of psychoanalysis (A. Sheridan, Trans.) Jacques-Alain Miller ed., New York: Norton. 
Laclau, E. \& Mouffe, C. (2001). Hegemony and socialist strategy: Towards a radical democratic politics. London: Verso.

Leavis, F. R. (1998). The critic as anti-philosopher: Essays and papers. Chicago: Ivan R. Dee Inc.

Lecercle, J. (2008). Raymond Williams (G. Elliot, Trans.). In J. Bidet \& S. Kouvelakis (Eds.), Critical Companion to Contemporary Marxism (pp. 741-750). Leiden: Koninklijke Brill NV.

Lefebvre, H. (2014). Critique of everyday life: The one-volume edition (J. Moore, Trans.). London: Verso,

Lenin, V. I. (1992). The state and revolution (R. Service, Trans.). London: Penguin Books.

Lenin, V. I. (2010). Imperialism: The highest stage of capitalism. London: Penguin Books Ltd.

Levi-Strauss, C. (1963). Structural anthropology (C. Jacobson, Trans.). New York: Basic Books.

Laclau, E. \& Mouffe, C. (2001). Hegemony and socialist strategy (2 ${ }^{\text {nd }}$ ed.). London: Verso.

Lowy, M. (1983). Lukacs and Stalinism. In New Left Review (Ed.), Western Marxism: A critical reader ( $2^{\text {nd }}$ ed.) (pp. 61-82). London: Verso.

Lukacs, G. (1963). Ästhetik. teil I. Die eigenart des asthetischen. Neuwied-Berlin: Luchterhand.

Lukacs, G. (1971). Lukacs on his life and work. New Left Review, vol. I/68 (July-August), pp. 49-58.

Lukacs, G. (1979). The meaning of contemporary realism. Monmouth: The Merlin Press.

Lukacs, G. (1983a). Essays on realism. R. Livingstone (ed.). Massachusetts: MIT Press.

Lukacs, G. (1983b). Record of a life (R. Livingstone, Trans.). London: Verso.

Lukacs, G. (1983c). The historical novel (H. \& S. Mitchell, Trans.). Lincoln: University of Nebraska Press.

Lukacs, G. (2006). The theory of the novel (A. Bostock, Trans.). Monmouth: The Merlin Press.

Lukacs, G. (2007). Realism in the balance. In T. Adorno, W. Benjamin, E. Bloch, B. Brecht \& G. Lukacs (Eds.), Aesthetics and politics (2nd ed.) (pp. 28-59). London: Verso.

Lukacs, G. (2010). History and class consciousness (5 $5^{\text {th }}$ ed.) (R. Livingstone, Trans.). Pontypool: The Merlin Press. 
Lukacs, G. (2014). Studies in European realism. London: The Merlin Press.

Luxembourg, R. (2013). The accumulation of capital ( $2^{\text {nd }}$ ed.). Oxon: Routledge.

Lyotard, J. F. (2004). The postmodern condition: A report on knowledge (University of Minesota, Trans.). Manchester: Manchester University Press.

Mansfield, N. (2000). Subjectivity: Theories of the self from Freud to Haraway. New York: New York University Press.

Marcuse, H. (2002). One dimensional man. Routledge: Oxon

Marcuse, H. (2005). Eros and civilisation. Routledge: Oxon.

Marx, K. (1992). Capital: Volume II (D. Fernbach, Trans.). London: Penguin Books Ltd.

Marx, K. (1993). Grundrisse (M. Nicolaus, Trans.). London: Penguin Books Ltd.

Marx, K. (2008). Capital: A new abridgement (D. McLellan et al Trans.) David McLellan ed., Oxford University Press: New York.

Marx, K. (2010). Economic and philosophic manuscripts of 1844. In Essential writings of Karl Marx, St Petersburg: Red and Black Publishers.

Marx, K. (2012). The eighteenth Brumaire of Louis Bonaparte (D. de Leon, Trans.). Digireads.com Publishing.

Masnatta, C. (2010). Raymond Williams in the south Atlantic. In Grossberg, L, Horak, R. \& Seidl, M. (eds.) About Raymond Williams. Abingdon: Routledge.

McNally, M. (2015). Antonio Gramsci: Critical explorations in contemporary political thought. Basingstoke: Palgrave Macmillan.

Meiville, C. (2017). October: The story of the Russian revolution. London: Verso.

Merrington, J. (1983). Theory and practice in Gramsci's Marxism. In New Left Review (Ed.), Western Marxism: A critical reader ( $2^{\text {nd }}$ ed.) (pp. 140-175). London: Verso.

Miklitsch, R. (1995). News from somewhere: Reading Williams's readers. In C. Prendergast (Ed.), Cultural materialism: On Raymond Williams (pp. 71-90). Minnesota: University of Minnesota Press.

Mill, J. S. (2005). On liberty. New York: Cosimo.

Milner, A. (2002). Re-imagining cultural studies: The politics of cultural materialism. London: Sage Publications.

Montag, W. (2013). Althusser and his contemporaries: Philosophy's perpetual war. London: Duke University Press. 
Moriarty, M. (1992). The longest cultural journey: Raymond Williams and French theory. Social Text, no. 30, pp. 57-77.

Mulhern, F. (1984). Towards 2000 or news from you-know-where. New Left Review, vol. I/148 (November-December), pp. 5-30.

Mulhern, F. (2009). Culture and society: Then and now. New Left Review, vol. 55 (JanuaryFebruary), pp. 34-45.

Murdoch, I. (1987). Sartre: Romantic rationalist. New York: Viking.

Nairn, T. (1972). The left against Europe. New Left Review (Special Issue), vol. I/75, pp. 5120.

Neale, R. S. (1984). Cultural materialism: A critique. Social History, vol. 9(2), pp. 199-215.

Nonini, D. M. (1999). Race, land, nation: A(t)-tribute to Raymond Williams. Cultural Critique, no. 41 (Winter), pp. 158-183.

Novak, G. (2011). Polemics in Marxist philosophy: Essays on Sartre, Plekhanov, Lukacs, Engels, Kolakowski, Trotsky, Timpanaro, Colletti (8th ed.). New York: Pathfinder Press

O’Connor, A. (1989). Raymond Williams: Writing, culture, politics. Oxford: Basil Blackwell.

Pfiefer, G. (2015). The new materialism: Althusser, Badiou, and Zizek, Oxon: Routledge.

Pinkney, T. (1991). Border lines. Bridgend: Seren Books.

Pinkney, T. (2007a). Modernism and cultural theory. Introduction to T. Pinkney (ed.), Politics of modernism: Against the new conformists. London: Verso.

Pinkney, T. (2007b). Raymond Williams and the 'two faces of modernism'. In T. Eagleton (Ed.), Raymond Williams: Critical perspectives ( ${ }^{\text {rd }}$ ed.) (pp. 12-33). Cambridge: Polity Press.

Polanyi, K. (2001). The great transformation ( $2^{\text {nd }}$ ed.). Boston: Beacon Press.

Rousseau, J. (1998). The social contract or principles of political right (H. J. Tozer, Trans.). Ware: Wordsworth Editions Ltd.

Said, E. W. (1983). Travelling theory. In E. W. Said (Ed.), The world the text and the critic (pp. 226-247). Cambridge: Harvard University Press.

Said, E. W. (2003). Orientalism (3 ${ }^{\text {rd }}$ ed.). London: Penguin Books Ltd.

Sartre, J. (1960). The devil and the good lord (B. Kitty, Trans.). New York: Alfred A. Knopf.

Sartre, J. (1971). The Burgos trials (H. Webb, Trans.). Planet: The Welsh internationalist, vol. 8 (October-November), pp. 3-21. 
Sartre, J. (1973). Search for a method (H. E. Barnes, Trans.). New York: Random House.

Sartre, J. (1981a). Altona (G. \& S. Leeson, Trans.). In Jean-Paul Sartre: Three plays (pp. 7166). London: Penguin Books.

Sartre, J. (1981b). Men without shadows (K. Black, Trans.). In Jean-Paul Sartre: Three plays (pp. 167-230). London: Penguin Books.

Sartre, J. (1989a). Dirty hands (I. Abel, Trans.). In No exit and three other plays (pp. 125242). New York: Vintage.

Sartre, J. (1989b). No exit (S. Gilbert, Trans.). In No exit and three other plays (pp. 1-46). New York: Vintage.

Sartre, J. (1989c). The flies (S. Gilbert, Trans.). In No exit and three other plays (pp. 47-124). New York: Vintage.

Sartre, J. (2000). Nausea (R. Baldick. Trans.). London: Penguin.

Sartre, J (2001). What is literature? (B. Frechtman, Trans.). Abingdon: Routledge.

Sartre. J. (2003). Being and nothingness. A phenomenological essay on ontology (H. E. Barnes, Trans.). New York: Simon and Schuster.

Sartre, J. (2004). Critique of dialectical reason: Vol. 1 (New Left Books, Trans.). London: Verso.

Sartre, J. (2007). Existentialism is a humanism (P. Mairet, Trans.). York: Methuen \& Co.

Sartre, J. (2008). Between existentialism and Marxism (New Left Books, Trans.). London: Verso.

Sassoon, D. (2014). One hundred years of socialism: The west European left in the twentieth century $\left(4^{\text {th }}\right.$ ed.). London: I. B. Tauris \& Co Ltd.

Saussure, F. (2011). Course in general linguistics (W. Baskin, Trans.). New York: Columbia University Press.

Schroeder, W. R. (2005). Continental philosophy: A critical approach. Oxford: Blackwell Publishing Ltd.

Schumpeter, J. (2011). Capitalism, socialism and democracy ( $2^{\text {nd }}$ ed.). Connecticut: Martino Publishing.

Scruton, R. (2001). Kant: A very short introduction ( $2^{\text {nd }}$ ed.). Oxford: Oxford University Press.

Singer, P. (2001). Hegel: A very short introduction ( $2^{\text {nd }}$ ed.). Oxford: Oxford University Press. 
Singleton, K. (2007). Raymond Williams, Jurgen Habermas and communicative resources. Ryerson: Ryerson University.

Smith, D. (2007). Relating to Wales. In T. Eagleton (Ed.), Raymond Williams: Critical perspectives (3rd ed.) (pp. 34-53). Cambridge: Polity Press.

Smith, D. (2008). Raymond Williams: A warrior's tale. Cardigan: Parthian.

Solzhenitsyn, A. (2003). The gulag archipelago (2nd ed.) (Harper \& Row, Trans.). London: The Harvill Press.

Steiner, G. (1996). The death of tragedy ( $2^{\text {nd }}$ ed.). Yale: Yale University Press.

Therborn, G. (1983). The Frankfurt school. In New Left Review (Ed.), Western Marxism: A critical reader (2nd ed.) (pp. 140-175). London: Verso.

Therborn, G. (2012). Class in the $21^{\text {st }}$ century. New Left Review, vol. 2(78) (NovemberDecember).

Thomas, N. (1971). The Welsh extremist. Talybont: Y Lolfa.

Thompson, E. P. (undated). Personal communication. This item is among the papers of Raymond Williams, held in the Richard Burton Archives at Swansea University.

Thompson, E. P. (1961a). The long revolution (part I). New Left Review, vol. I/10 (MayJune), pp. 24-33.

Thompson, E. P. (1961b). The long revolution (part II). New Left Review, vol. I/10 (JulyAugust), pp. 34-39.

Thompson, E. P. (1965). The peculiarities of the English. Socialist Register, vol. 2 pp. 311 362.

Thompson, E. P. (1995). The poverty of theory: An orrery of errors $\left(2^{\text {nd }}\right.$ ed.). London: The Merlin Press Ltd.

Thompson, E. P. (2013). The making of the English working class $\left(3^{\text {rd }}\right.$ ed.). London: Penguin Books Ltd.

Thompson, J. (1992). Realisms and modernisms: Raymond Williams and popular fiction. In D. L. Dworkin \& L. G. Roman (Eds.), Views beyond the border country: Raymond Williams and cultural politics (pp. 72-90). London: Routledge.

Timpanaro, S. (1980). On materialism. London: Verso.

Timpanaro, S. (2011). The Freudian slip. London: Verso.

Ward, J. P. (1981). Raymond Williams. Cardiff: University of Wales Press. 
Watkins, E. (1976). Raymond Williams and Marxist criticism. boundary 2, vol. 4(3) (Spring), pp. 933-946.

West, C. (1992). The legacy of Raymond Williams. Social Text, no. 30, pp. 6-8.

Williams, D. (2003). Who speaks for Wales? Nation, culture, identity: Raymond Williams. Cardiff: University of Wales Press.

Williams, D. (2010). Writing against the grain: Raymond Williams's border country (1960) and the defence of realism. In Gramich, K. (Ed.), Mapping the territory: Critical approaches to Welsh fiction in English. Cardigan: Parthian.

Williams, G. A. (1960). The concept of "egemonia" in the thought of Antonio Gramsci: Some notes of interpretation. Journal of the history of ideas, vol. 21(4) (OctoberDecember), pp. 586-599.

Williams, R. (1961, March 30). Creators and consumers. The Guardian, p. 10.

Williams, R. (1962, March 8). From Scott to Tolstoy. The Listener, pp. 436-437.

Williams, R. (1963, February 28). Review of the meaning of contemporary realism. The Listener, no. 69.

Williams, R. (1965). Review of 'the genius of Scandinavian theatre' by Sprinchorn, E. Scandinavica, vol. 4(2).

Williams, R. (1966). Modern tragedy. London: Chatto \& Windus.

Williams, R. (1967a). Drama from Ibsen to Eliot ( $2^{\text {nd }}$ ed.). Middlesex: Peregrine Books.

Williams, R. (1967b, May 12). Novels and ideas. The Guardian, p. 8.

Williams, R. (1968a). The mayday manifesto $\left(2^{\text {nd }}\right.$ ed.). London: Cox and Wyman.

Williams, R. (1968b, November 29). The need for Sartre. The Guardian, p 11.

Williams, R. (1969). 'On reading Marcuse', review of Negations by Herbert Marcuse. The Cambridge Review, 90, pp. 366-368.

Williams, R. (1970a). The English novel from dickens to Lawrence. London: Chatto \& Windus.

Williams, R. (1970b, April 22). Young Brecht. The Guardian, p. 19.

Williams, R. (1971, February 25). Socialism active and passive. The Guardian, p. 8.

Williams, R. (1972, March 23). Lucien Goldmann and Marxism's alternative tradition. The Listener, no. 87, pp. 375-376.

Williams, R. (1974, April 25). Who are the intellectuals? The Guardian, p. 17. 
Williams, R. (1974, January $3^{\text {rd }}$ ). Notebook entitled 'Theories of Culture'. Richard Burton Archives; Raymond Williams Papers (WWE/2/1/12/16). Swansea University Libraries \& Archives.

Williams, R. (1977a, May 5). French connection. New Society, pp. 239-240.

Williams, R. (1977b, January 20). Meanings of dialectic. The Guardian, p. 14.

Williams, R. (1978a, January 5). Class of the conscious. New Society, pp. 26-27.

Williams, R. (1978b, March 23). Explaining the word. The Guardian, p. 11.

Williams, R. (1980a, November 20). Realism again. New Society, pp. 381-382.

Williams, R. (1980b, January 24). What is anti-capitalism? New Society, pp. 189-190.

Williams, R. (1981a). English Brecht. London Review of Books, vol. 3(13), pp. 19-20.

Williams, R. (1981b, January 29). Straddling the chasm. The Guardian, p. 7.

Williams, R. (1983a). Culture. Glasgow: Fontana Paperbacks.

Williams, R. (1983b). Drama from Ibsen to Brecht. Middlesex: Pelican Books.

Williams, R. (1983c, February). The red and the green. London Review of Books, vol. 5(2), pp. 3-16.

Williams, R. (1984a, May 17). A man without frustration. London Review of Books, vol. 6(9), pp. 14-15.

Williams, R. (1984b, June 21). Goodbye to Sartre. New Society, pp. 470-471.

Williams, R. (1985a), Crisis in English studies. In R. Williams, Writing in society (pp. 192211). London: Verso.

Williams, R. (1985b). David Hume: Reasoning and experience. In R. Williams, Writing in society (pp.121-143). London: Verso.

Williams, R. (1985c). Region and class in the novel. In R. Williams, Writing in society (pp. 229-238). London: Verso.

Williams, R. (1985d). The English novel from Dickens to Lawrence. London: Hogarth Press.

Williams, R. (1985e). Towards 2000. Middlesex: Pelican.

Williams, R. (1988a). Second generation. London: The Hogarth Press.

Williams, R. (1988b). The fight for Manod. London: The Hogarth Press. 
Williams, R. (1989a). An alternative Politics. In R. Gable (Ed.), Resources of hope (pp. 151160). Verso: London.

Williams, R. (1989b). Art: Freedom and duty. In R. Gable (Ed.), Resources of hope (pp. 8896). Verso: London.

Williams, R. (1989c). Communications and community. In R. Gable (Ed.), Resources of hope (pp. 19-31). Verso: London.

Williams, R. (1989d). Culture is ordinary. In R. Gable (Ed.), Resources of hope (pp. 3-18). Verso: London.

Williams, R. (1989e). Hesitations before socialism. In R. Gable (Ed.), Resources of hope (pp. 288-294). Verso: London.

Williams, R. (1989f). Ideas and the Labour movement. In R. Gable (Ed.), Resources of hope (pp. 141-150). Verso: London.

Williams, R. (1989g). Loyalties. London: The Hogarth Press.

Williams, R. (1989h). Problems of the coming period. In R. Gable (Ed.), Resources of hope (pp. 161-174). Verso: London.

Williams, R. (1989i). Socialism and ecology. In R. Gable (Ed.), Resources of hope (pp. 210226). Verso: London.

Williams, R. (1989j). Socialists and coalitionists. In R. Gable (Ed.), Resources of hope (pp. 175-186). Verso: London.

Williams, R. (1989k). The British left. In R. Gable (Ed.), Resources of hope (pp. 131-140). Verso: London.

Williams, R. (19891). The idea of a common culture. In R. Gable (Ed.), Resources of hope (pp. 32-38). Verso: London.

Williams, R. (1989m). The practice of possibility. In R. Gable (Ed.), Resources of hope (pp. 314-322). Verso: London.

Williams, R. (1989n). The writer: Commitment and alignment. In R. Gable (Ed.), Resources of hope (pp. 77-87). Verso: London.

Williams, R. (1989o). Towards many socialisms. In R. Gable (Ed.), Resources of hope (pp. 295-313). Verso: London.

Williams, R. (1989p). Walking backwards into the future. In R. Gable (Ed.), Resources of hope, (pp. 281-187). Verso: London.

Williams, R. (1989q). Why do I demonstrate? In R. Gable (Ed.), Resources of hope (pp. 5964). Verso: London. 
Williams, R. (1989r). You're a Marxist, aren't you? In R. Gable (Ed.), Resources of hope (pp. 65-76). Verso: London.

Williams, R. (1990a). A defence of realism. In R. Williams (Ed.), What I came to say (pp. 226-239). London: Hutchinson Radius.

Williams, R. (1990b). Commitment. In R. Williams (Ed.), What I came to say (pp. 256-260). London: Hutchinson Radius.

Williams, R. (1991). Drama in performance ( $2^{\text {nd }}$ ed.). Buckingham: Open University Press.

Williams, R. (2003a). Are we becoming more divided? In D. Williams (Ed.), Who speaks for Wales? Nation, culture, identity: Raymond Williams (pp. 186-190). Cardiff: University of Wales Press.

Williams, R. (2003b). Community. In D. Williams (Ed.), Who speaks for Wales? Nation, culture, identity: Raymond Williams (pp. 27-33). Cardiff: University of Wales Press.

Williams, R. (2003c). Decentralism and the politics of place. In D. Williams (Ed.), Who speaks for Wales? Nation, culture, identity: Raymond Williams (pp. 204-211). Cardiff: University of Wales Press.

Williams, R. (2003d). Marxism, poetry, Wales. In D. Williams (Ed.), Who speaks for Wales? Nation, culture, identity: Raymond Williams (pp. 81-94). Cardiff: University of Wales Press.

Williams, R. (2003e). Remaking Welsh history. In D. Williams (Ed.), Who speaks for Wales? Nation, culture, identity: Raymond Williams (pp. 69-72). Cardiff: University of Wales Press.

Williams, R. (2003f). Television ( $2^{\text {nd }}$ ed.). Abingdon: Routledge.

Williams, R. (2003g). The culture of nations. In D. Williams (Ed.), Who speaks for Wales? Nation, culture, identity: Raymond Williams (pp. 191-204). Cardiff: University of Wales Press.

Williams, R. (2003h). The importance of community. In D. Williams (Ed.), Who speaks for Wales? Nation, culture, identity: Raymond Williams (pp. 177-185). Cardiff: University of Wales Press.

Williams, R. (2003i). Wales and England. In D. Williams (Ed.). Who speaks for Wales? Nation, culture, identity: Raymond Williams (pp. 16-26). Cardiff: University of Wales Press.

Williams, R. (2003j). Welsh culture. In D. Williams (Ed.), Who speaks for Wales? Nation, culture, identity: Raymond Williams (pp. 5-11). Cardiff: University of Wales Press. 
Williams, R. (2003k). Who speaks for Wales? In D. Williams (Ed.), Who speaks for Wales? Nation, culture, identity: Raymond Williams (pp. 3-4). Cardiff: University of Wales Press.

Williams, R. (2005a). A hundred years of culture and anarchy. In R. Williams, Culture and materialism ( $2^{\text {nd }}$ ed.) (pp. 3-10). London: Verso.

Williams, R. (2005b). Advertising: The magic system. In R. Williams, Culture and materialism ( $2^{\text {nd }}$ ed.) (pp. 170-198). London: Verso.

Williams, R. (2005c). Base and superstructure in Marxist cultural theory. In R. Williams, Culture and materialism (2 ${ }^{\text {nd }}$ ed.) (pp. 31-49). London: Verso.

Williams, R. (2005d). Beyond actually existing socialism. In R. Williams, Culture and materialism ( $2^{\text {nd }}$ ed.) (pp. 252-274). London: Verso.

Williams, R. (2005e). Ideas of nature. In R. Williams, Culture and materialism ( $2^{\text {nd }}$ ed.) (pp. 67-85). London: Verso.

Williams, R. (2005f). Literature and sociology. In R. Williams, Culture and materialism ( $2^{\text {nd }}$ ed.) (pp. 11-30). London: Verso.

Williams, R. (2005g). Means of communication as means of production. In R. Williams, Culture and materialism ( $2^{\text {nd }}$ ed.) (pp. 50-66). London: Verso.

Williams, R. (2005h). Notes on Marxism in Britain since 1945. In R. Williams, Culture and materialism ( $2^{\text {nd }}$ ed.) (pp. 233-251). London: Verso.

Williams, R. (2005i). Problems of materialism. In R. Williams, Culture and materialism ( $2^{\text {nd }}$ ed.) (pp. 103-124). London: Verso.

Williams, R. (2005j). The Welsh industrial novel. In R. Williams, Culture and materialism $\left(2^{\text {nd }}\right.$ ed.) (pp. 213-232). London: Verso.

Williams, R. (2007a). The future of cultural studies. In R. Williams, Politics of modernism: Against the new conformists ( $2^{\text {nd }}$ ed.) (pp. 151-162). London: Verso.

Williams, R. (2007b) The uses of cultural theory. In Politics of modernism: Against the new conformists $\left(2^{\text {nd }}\right.$ ed.) (pp. 163-176). London: Verso.

Williams, R. (2009). Marxism and literature. Oxford: Oxford University Press. First published 1977.

Williams, R. (2010). Border country (3 ${ }^{\text {rd }}$ ed.). Cardigan: Parthian. First published 1960.

Williams, R. (2011a). The country and the city. Nottingham: Spokesman. First published 1973.

Williams, R. (2011b). The long revolution. Cardigan: Parthian. First published 1961. 
Williams, R. (2013). Culture and society. Nottingham: Spokesman. First published 1958.

Williams, R. (2014). Keywords. London: Fourth Estate. First published 1976.

Williams, R. (2015). Politics and letters. London: Verso. First published 1979.

Wood, E. M. (1995). A chronology of the new left and its successors, or: Who's oldfashioned now? Socialist Register, vol. 31, pp. 22-49.

Wood, E. M. (2005). Empire of capital. London: Verso.

Wood, E. M. (2016). Democracy against capitalism: Reviving historical materialism. London: Verso.

Wright, E. O. (1979). Class, crisis and the state. London: Verso.

Wright, E. O. (1997). Classes. London: Verso.

Vincent, J. (2008). Adorno and Marx (G. Elliot, Trans.). In J. Bidet \& S. Kouvelakis (Eds.) Critical companion to contemporary Marxism. Leiden: Koninklijke Brill NV.

Volpe, G. D. (1991). Critique of taste (New Left Books, Trans.). London: Verso.

Zizek, S. (2008). The sublime object of ideology ( ${ }^{\text {rd }}$ ed.). London: Verso. 